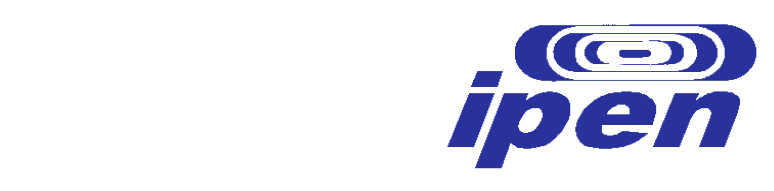

INSTITUTO DE PESQUISAS ENERGÉTICAS E NUCLEARES

Autarquia associada à Universidade de São Paulo

Estudo da resistência à corossão do aço inoxidável ferrítico AISI 444 para aplicação como biomaterial

Rogério Albuquerque Marques

Tese apresentada como parte dos requisitos para obtenção do Grau de Doutor em Ciências na Área de Tecnologia Nuclear - Materiais.

Orientadora:

Prof ${ }^{a}$. Dra. Isolda Costa

São Paulo

2014 


\section{INSTITUTO DE PESQUISAS ENERGÉTICAS E NUCLEARES}

Autarquia associada à Universidade de São Paulo

Estudo da resistência à corossão do aço inoxidável ferrítico AISI 444 para aplicação como biomaterial

Rogério Albuquerque Marques

Tese apresentada como parte dos requisitos para obtenção do Grau de Doutor em Ciências na Área de Tecnologia Nuclear - Materiais.

Orientadora:

Prof ${ }^{a}$. Dra. Isolda Costa

Versão corrigida

Versão original disponível no IPEN

São Paulo 


\section{AGRADECIMENTOS}

À minha esposa Janaina e minha cachorrinha Kalina Perrolindo que sempre me apoiaram para que eu continuasse os meus estudos.

Aos meus pais Cleuza e Wanderley.

À Prof ${ }^{a}$. Dra. Isolda Costa pela orientação, amizade e incentivo para a concretização deste trabalho.

Ao Prof. Dr. Adonis Marcelo Saliba-Silva pela orientação durante o meu mestrado no IPEN.

À Dra. Maysa Terada pela amizade e colaboração com as análises por imagem.

Ao amigo Msc Eurico F. Pieretti por todas as sugestões dadas a este trabalho.

Ao técnico e amigo Olandir V. Correa que sempre se dispôs a colaborar.

À Prof ${ }^{a}$. Sizue O. Rogero pela colaboração com as análises de citotoxicidade.

Ao IPEN pela oportunidade de desenvolvimento deste trabalho.

À CNEN pelo apoio financeiro.

À FAPESP pelo apoio finaceiro através do processo 2012/50288-8

A todos os outros colegas, com os quais tive a oportunidade de conviver durante estes últimos oito anos de pós-graduação no IPEN. 
DEDICATÓRIA

À minha esposa Janaina 
"A mente que se abre a uma nova idéia jamais voltará ao seu tamanho original."

Albert Eistein 


\title{
ESTUDO DA RESISTÊNCIA À CORROSÃO DO AÇO AISI 444 PARA APLICAÇÃO COMO BIOMATERIAL
}

\author{
Rogério Albuquerque Marques
}

\begin{abstract}
RESUMO
Os aços inoxidáveis ferríticos são naturalmente ferromagnéticos, o que impossibilita sua utilização em próteses ortopédicas. Apesar disso, em algumas aplicações específicas, faz-se necessário o uso de um biomaterial ferromagnético, como nas próteses odontológicas e faciais com conectores magnéticos. Este trabalho apresenta o estudo da resistência à corrosão e citotoxicidade do aço inoxidável ferrítico AISI 444, para avaliar seu potencial de uso como um biomaterial. O aço AISI 444 possui baixo teor de níquel, teores extrabaixos de intersticiais ( $\mathrm{C}$ e $\mathrm{N}$ ) e é estabilizado com $\mathrm{Ti}$ e $\mathrm{Nb}$. Como materiais de referência foram utilizados o aço inoxidável austenítico ISO 5832-1 (ASTM F-138), por ser o biomaterial metálico mais empregado na fabricação de próteses ortopédicas, e uma base ferromagnética do sistema de fixação de próteses odontológicas, feita em aço inoxidável ferrítico (NeoM). O ensaio de citotoxicidade in vitro, pelo método de incorporação do corante vermelho neutro, revelou que o aço inoxidável AISI 444 não apresentou citotoxicidade. O comportamento frente à corrosão foi estudado por meio de curvas de polarização anódica potenciodinâmicas e espectroscopia de impedância eletroquímica (EIE). O meio de ensaio foi uma solução salina tamponada de fosfato (PBS), em condição naturalmente aerada e em fresta, a temperatura de $37^{\circ} \mathrm{C}$. Para simular a condição de fresta dos ensaios eletroquímicos foi desenvolvido um novo equipamento. As propriedades eletrônicas do filme passivo foram avaliadas pela técnica de Mott-Schottky. Em meio aerado, os resultados de EIE indicaram que todos os materiais se mostraram passivos. As curvas de polarização indicaram que a resistência à corrosão por pite do aço AISI 444 foi equivalente à do aço ISO 5832-1, porém superior à do NeoM. Pelos diagramas de Mott-Schottky, conclui-se que o filme óxido no aço AISI 444 possui menor concentração de dopantes que o aço NeoM. Isto sugere que o aço AISI 444 apresenta maior resistência à transferência de carga através do filme passivo. Em condição de fresta, as polarizações indicaram taxas de corrosão baixas para ambos os aços, porém superiores para o aço ISO 5832-1, em comparação ao aço AISI 444. As micrografias das superfícies dos aços, após polarização, revelaram um maior ataque corrosivo no aço ISO 5832-1 do que no aço AISI 444. O aço NeoM apresentou composição química fora da especificação da norma. Os baixos teores de $\mathrm{Cr}$ e de Mo, além das altas concentrações de sulfetos, foram as prováveis causas da menor resistência à
\end{abstract}


corrosão do NeoM, indicada pelos ensaios eletroquímicos. O equipamento proposto para avaliação da resistência à corrosão, em condição de fresta, mostrou boa reprodutibilidade de resultados. O aço inoxidável AISI 444 apresentou alta potencialidade para uso como biomaterial, especialmente na fabricação de componentes protéticos com fixação magnética. 


\title{
STUDY ON THE CORROSION RESISTANCE OF AISI 444 STAINLESS STEEL FOR APPLICATION AS BIOMATERIAL
}

\author{
Rogério Albuquerque Marques
}

\begin{abstract}
Ferritic stainless steels are ferromagnetic materials. This property does not allow their use in orthopedic prosthesis. Nevertheless, in some specific applications, this characteristic is very useful, such as, for fixing dental and facial prostheses by using magnetic attachments. In this study, the corrosion resistance and cytotoxicity of the AISI 444 ferritic stainless steel, with low nickel content, extra-low interstitial levels ( $\mathrm{C}$ and $\mathrm{N}$ ) and with the addition of $\mathrm{Ti}$ and $\mathrm{Nb}$ as stabilizers, were investigated to evaluate its potentiality for biomaterials fabrication. The ISO 5832 austenitic stainless steel (SS) and a commercial universal keeper for dental attachment (Neo-magnet System) were evaluated for comparison reasons. The first stainless steel is the most used metallic material for orthopedic prostheses fabrication, and the second one, is a ferromagnetic keeper for dental prostheses (NeoM). In vitro cytotoxicity analysis was performed by the red neutral incorporation method. The results showed that the AISI 444 stainless steel is non cytotoxic. The corrosion resistance was studied by anodic polarization methods and electrochemical impedance spectroscopy (EIS), in a saline phosphate buffered solution (PBS) at $37{ }^{\circ} \mathrm{C}$, either naturally aerated or under crevice condition. A new device was developed to simulate the crevice condition on electrochemical tests. The electronic properties of the passive film formed on AISI 444 SS were evaluated by the Mott-Schottky approach. All tested materials showed passivity in the PBS medium and the passive oxide film presented a duplex nature. In aerated condition, the resistance to pitting corrosion associated to AISI 444 SS was similar to that of the ISO 5832 SS and both were superior to that of the NeoM SS. The 444 SS oxide film showed lower dopants concentration than the NeoM SS, suggesting that the 444 SS film presents a higher resistance to charge transfer through it than the fim on the NeoM SS. Under crevice conditions, the potentiodinamic polarization tests indicated low corrosion rates for both steels, but slightly higher for the ISO 5832 SS when compared to the AISI 444 SS tested. Observation of the surface, after crevice polarization, indicated a larger area of corrosive attack on the ISO 5832-1 SS than on the AISI 444 SS. The chemical composition of the NeoM SS was out of the standard specification. The low levels of $\mathrm{Cr}$ and $\mathrm{Mo}$ in the NeoM, and the high concentration of MnS precipitates, are the probable cause of its lower corrosion resistance. The new devide proposed for crevice corrosion resistance evaluation, showed good reproducibility of results. The
\end{abstract}


AISI 444 stainless steel showed a high potential for use as a biomaterial, especially for the manufacture of prosthetic components with magnetic attachment. 


\section{SUMÁRIO}

Página

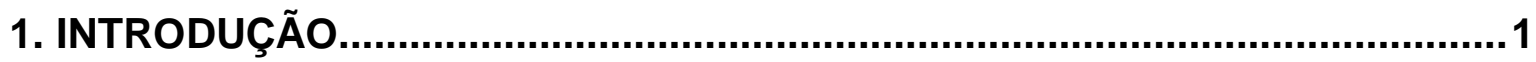

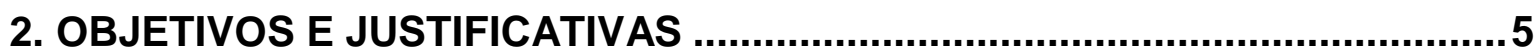

3. REVISÃO DA LITERATURA

3.1 Sistema de fixação magnética para próteses...........................................6

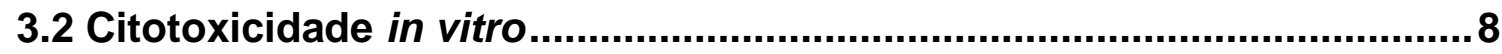

3.3 Exames de imagem por ressonância magnética....................................10

3.4 Aços inoxidáveis ...............................................................................11

3.5 Corrosão de ligas metálicas e técnicas eletroquímicas ........................13

3.5.1 Espectroscopia por impedância eletroquímica (EIE) e circuitos elétricos

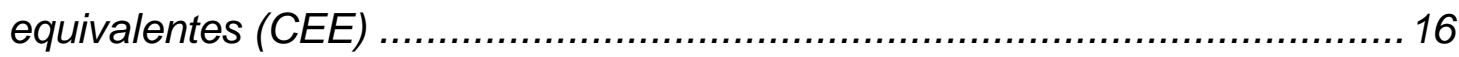

3.5.2 Propriedades eletrônicas do filme passivo - Técnica de Mott-Schottky.20

3.6 Corrosão em frestas 24

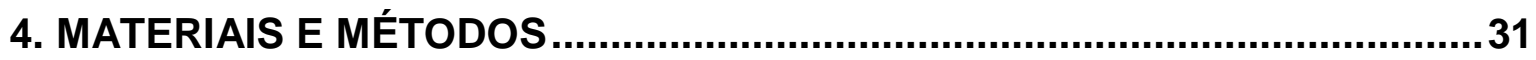

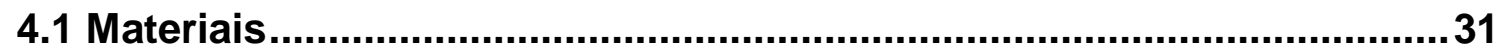

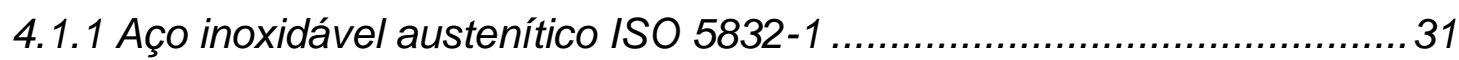

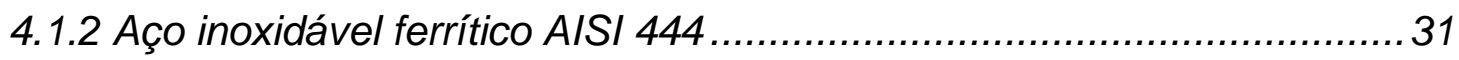

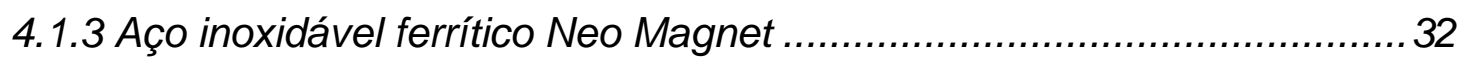

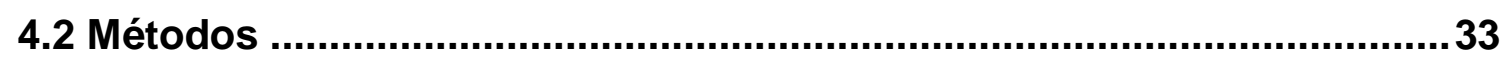

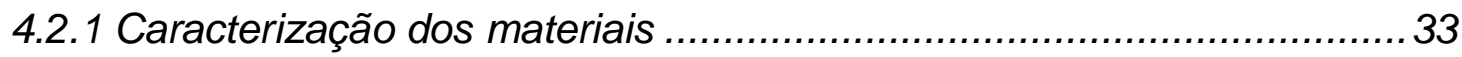

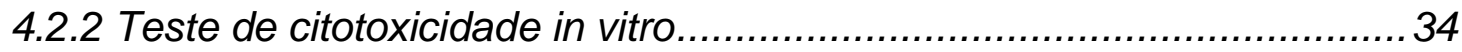

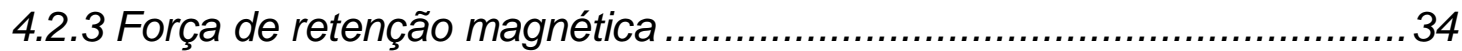

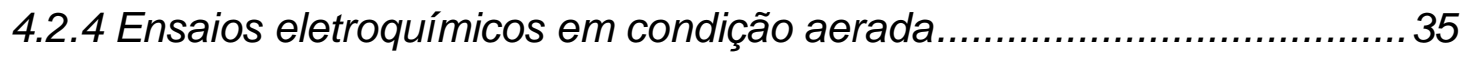

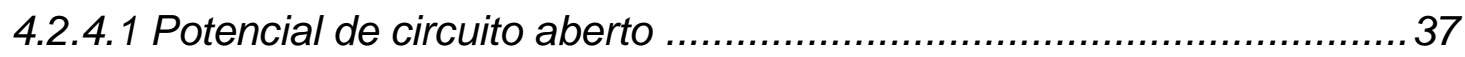

4.2.4.2 Espectroscopia de impedância eletroquímica (EIE) .........................37

4.2.4.3 Polarização anódica potenciodinâmica cíclica ..................................37 
4.2.4.4 Gráficos de Mott-Schottky - Propriedades eletrônicas do filme passivo

4.2.5 Ensaios eletroquímicos em condição de fresta................................ 38

5. RESULTADOS E DISCUSSÃO ................................................................ 41

5.1 Caracterização dos materiais ........................................................... 41

5.1.1 Aço inoxidável austenítico ISO 5832-1 ........................................ 41

5.1.2 Aço inoxidável ferrítico AISI 444 .................................................. 44

5.1.3 Aço inoxidável Neo Magnet ........................................................ 48

5.1.4 Comparação da análise química com a microanálise superficial por EDS

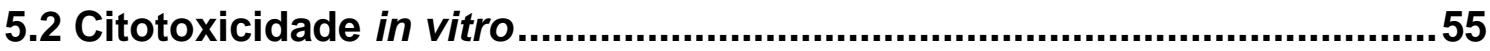

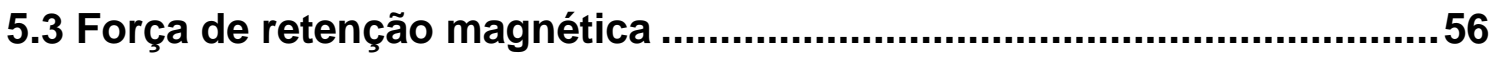

5.4 Potencial de circuito aberto em condição naturalmente aerada ............57

5.5 Curvas de polarização anódica potenciodinâmica cíclica em condição naturalmente aerada .................................................................................. 58

5.6 Ensaios de espectroscopia de impedância eletroquímica (EIE) em condição naturalmente aerada ...................................................................64 64

5.6.1 Aço inoxidável austenítico ISO 5832-1 ........................................6 64

5.6.2 Aço inoxidável ferrítico AISI 444 ..................................................65

5.6.3 Aço inoxidável ferrítico NeoM .....................................................68 68

5.6.4 Comparação dos resultados de EIE dos três aços avaliados ...............69 69

5.6.5 Circuitos elétricos equivalentes (CEE) ....................................... 72

5.7 Propriedades eletrônicas do filme passivo - Gráficos de Mott-Schottky 76

5.7.1 Aço inoxidável Neo Magnet ................................................... 77

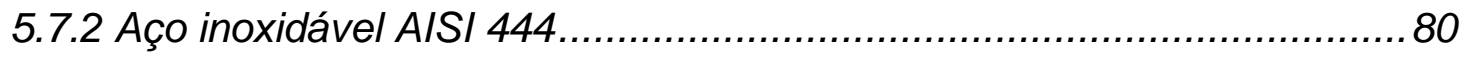

4.7.3 Comparação dos resultados de Mott-Schottky entre os aços inoxidáveis

AISI 444 e Neo Magnet ................................................................. 83

5.8 Ensaios eletroquímicos em condição de fresta .................................. 85

6. CONSIDERAÇÕES FINAIS......................................................................97 
7. CONCLUSÕES. 100

8. SUGESTÕES PARA TRABALHOS FUTUROS ...........................................102

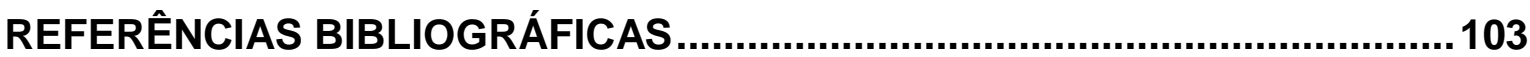

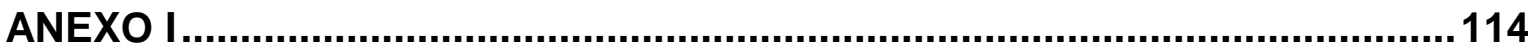

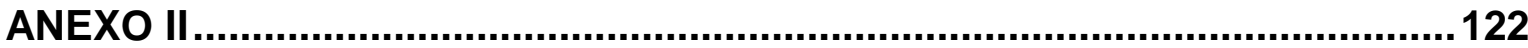




\section{LISTA DE TABELAS}

Página

Tabela 1 - Equivalência da norma JIS com as normas UNS e AISI para os aços citados neste trabalho. .15

Tabela 2 - Composição química (\% em massa) dos aços utilizados por TAKADA et al. (2007). 16

Tabela 3 - Composição química nominal (\% em massa) do aço ISO 5832-1 ........31

Tabela 4 - Composição química nominal (\% em massa) do aço AISI 444 32

Tabela 5 - Composição química nominal (\% em massa) do aço ferrítico NeoM, segundo a norma SUS 444 .

Tabela 6 - Composição química (\% em massa) da solução salina tamponada de fosfato (PAN et al., 2000).

Tabela 7 - Análise química (\% em massa) dos principais elementos de liga do aço ISO 5832-1

Tabela 8 - Análise química (\% em massa) dos principais elementos de liga do aço AISI 444

Tabela 9 - Composição química analisada do aço NeoM (\% em massa) e estabelecida pela norma JIS para o aço SUS 444.

Tabela 10 - Análise semiquantitativa e análise química dos principais elementos de ligas dos aços ISO 5832-1, AISI 444 e NeoM (\% em massa). .53

Tabela 11 - Efeito dos principais elementos de liga nas propriedades físicoquímicas dos materiais estudados. .54

Tabela 12 - Potenciais de circuito aberto dos aços NeoM, 444, 444S e ISO, após 48 horas de imersão em solução PBS.

Tabela 13 - Valores dos elementos dos circuitos elétricos equivalentes ajustados sobre os resultados de EIE dos aços ISO, 444 e 444S, após 2 dias de imersão, em meio PBS naturalmente aerado a $37^{\circ} \mathrm{C}$. .75

Tabela 14 - Valores dos elementos dos circuitos elétricos equivalentes ajustados sobre os resultados de EIE dos aços ISO, 444 e 444S, após 21 dias de imersão, em meio PBS naturalmente aerado a $37^{\circ} \mathrm{C}$. .75

Tabela 15 - Composição química semiquantitativa (EDS) dos principais elementos encontrados na inclusão da Figura 71 (\% em massa). .88 
Tabela 16 - Valores dos elementos dos circuitos elétricos equivalentes ajustados sobre os resultados de EIE dos aços ISO e 444, após 2 e 7 dias de imersão em meio PBS a $37^{\circ} \mathrm{C}$, em condição de fresta.

Tabela 17 - Valores dos elementos dos circuitos elétricos equivalentes ajustados sobre os resultados de EIE dos aços ISO e 444, após 2 e 7 dias de imersão em meio PBS a $37^{\circ} \mathrm{C}$, em condição de fresta e aerada. .91 


\section{LISTA DE FIGURAS}

Página

Figura 1 - Sistema magnético sobre implante. A) Imã; B) Conector protético; C) Implante. Fonte: Dyna Magnet Manual 2

Figura 2 - Prótese auricular sobre implantes com retenção magnética. Fonte: THOMAS, 1995 3

Figura 3 - Próteses totais superiores e inferiores com articulação e travamento anterior por magnetos. Fonte: WATANABE et al. (2002). .7

Figura 4 - Família dos aços inoxidáveis ferríticos - série 400. (ASTM A240/A240M, 2003) (SEDRIKS, 1996) Fonte: BOTTON, 2008. 13

Figura 5 - Circuitos elétricos equivalentes propostos para caracterizar a camada superficial de diferentes ligas metálicas (AZUMl et al., 1986, BUNDY et al., 1993, GE et al., 2001 HIROMOTO et al, 2002, LIU et al., 2003, ANTUNES, 2006, TERADA, 2008).

Figura 6 - Gráfico esquemático da resposta de capacitância de um óxido duplex em função do potencial, obtidos pelo método de Mott-Schottky. .20

Figura 7 - Padrões para preparação do ensaio de corrosão segundo a norma ABNT NBR 15613-4. A) Corpo de prova; B) Flange; C) Corpo de prova acoplado a haste ASTM G5. 26

Figura 8 - Imagens obtidas por MO das superfícies de fresta após o teste de estimulação/repassivação. (a) NiTi; (b) NiTiCu; (c) 316L; (d) Ti cp; (e) Ti6Al4V (CHENG et al., 2006).

Figura 9 - Arranjo experimental proposto por DAYAL et al. (1983) para estudo da corrosão em fresta. .28

Figura 10 - Micrografias óticas após ataque em fresta dos aços: A) 304 (0,086\% N), B) $316(0,16 \%$ N), C) $317(0,088 \%$ N) e D) 317 SS (0,14\% N). MUDALI e DAYAL (2000). .29

Figura 11 - Prótese ortopédica de fêmur. A parte proximal (b) encaixa-se na distal

(a), formando uma região de fresta (c). (RECLARU et al., 2014). 30

Figura 12 - Vista esquemática lateral do eletrodo usado para modificar o teste ASTM F746. Fonte: RONDELLI e VICENTINI (1998) 30

Figura 13 - Sistema de conectores Neo Magnet. Ímã e base ferromagnética. .....32 Figura 14 - Desenho esquemático do aparato para medição da força de retenção magnética. 
Figura 15 - Célula eletroquímica com arranjo de três eletrodos. 36

Figura 16 - Célula eletroquímica conectada ao sistema de aquecimento com controlador de temperatura digital microprocessado. 37

Figura 17 - A) Equipamento para simulação de corrosão em condição de fresta; B) Porta amostra (seta 1) e célula eletroquímica (seta 2); C e D) Amostra embutida (seta 1) e contracorpo (seta 2). 39

Figura 18 - MEV do aço inoxidável ISO-5832-1, após ataque eletrolítico com ácido oxálico $10 \%$.

Figura 19 - A) Micrografia obtida por MEV da superfície do aço ISO 5832-1 como recebido. B) Idem com maior magnificação.

Figura 20 - Micrografia por MEV do aço ISO 5832-1, conforme recebido. A) região de arrancamento de inclusão. B) EDS do local indicado pela seta.

Figura 21 - Micrografia por MEV do aço ISO 5832-1, após polimento metalográfico, mostrando a presença de inclusão. A) MEV. B) EDS. 43

Figura 22 - Micrografia por MEV do aço ISO 5832-1, após polimento metalográfico, mostrando a presença de inclusão. A) MEV. B) EDS .43

Figura 23 - Micrografia por MEV do aço ISO 5832-1, após polimento metalográfico, mostrando a presença de inclusão. A) MEV. B) EDS .43

Figura 24 - Microestrutura do aço AISI 444, como recebido. A) Após ataque com reagente Villela. B) Sem ataque. 44

Figura 25 - A) Micrografia obtida por MEV. B) Análise por EDS de região do aço AISI 444 com inclusão rica em $\mathrm{Ti}$ e $\mathrm{Nb}$. .45

Figura 26 - A) Micrografia obtida por MEV. B) Análise por EDS de região do aço AISI 444 com inclusão rica em Ti, Al, Zr, Ca e Mg. 45

Figura 27 - A) Micrografia por MEV. B) Análise por EDS da região do aço AISI 444 com inclusão rica em Si. 46

Figura 28 - A) Micrografia por MEV do aço AISI 444. B) Análise por EDS evidenciando a presença de precipitado rico em $\mathrm{Ti}$ e $\mathrm{Nb}$.

Figura 29 - Micrografia obtida por microscopia óptica do aço AISI 444. A) Como recebido; B) Após solubilização a $1050{ }^{\circ} \mathrm{C}$, durante 30 minutos. Ataque eletrolítico: $\mathrm{NaOH} 30 \%$.

Figura 30 - Micrografia por MEV do aço NeoM, após ataque eletrolítico em $\mathrm{NaOH}$ $30 \%(6 \mathrm{~V}$ por $20 \mathrm{~s})$ 
Figura 31 - Micrografia do aço NeoM como recebido. A) Componente NeoM e micrografia da amostra embutida B) Maior aumento mostrando grande quantidade de inclusões.

Figura 32 - Região de uma inclusão de sulfeto de manganês na liga NeoM. A)

MEV; B) EDS da região indicada pela seta.

Figura 33 - Região de uma inclusão de sulfeto de manganês na liga NeoM. A)

MEV; B) EDS da região indicada pela seta. 50

Figura 34 - Região de uma inclusão mista de sulfeto de manganês com óxido de alumínio e silício na liga NeoM. A) MEV; B) EDS da região indicada pela seta.

Figura 35 - Espectros de EDS para o metal base. A) Aço ISO 5832-1 B) Aço AISI 444 C) Aço NeoM .52

Figura 36 - Gráfico da composição química obtida por métodos químicos (\% em massa) dos principais elementos de liga dos aços ISO 5832-1, AISI 444 e NeoM. 53

Figura 37 - Valores do PRE dos aços ISO, NeoM e 444 calculados com base nos resultados de composição obtidos por análise química. .55

Figura 38 - Curvas de viabilidade celular obtidas pelo método de análise colorimétrica. .56

Figura 39 - Resultados da força de retenção magnética para os aços 444 e NeoM.

Figura 40 - Variação do potencial de circuito aberto ao longo do tempo de imersão de 48 horas, em solução PBS naturalmente aerada e a $37^{\circ} \mathrm{C}$, para os aços NeoM, 444, 444S e ISO.

Figura 41 - Curvas de polarização anódica potenciodinâmica cíclica, após 2 e 21 dias de imersão em solução PBS, naturalmente aerada a $37^{\circ} \mathrm{C}$, para os aços NeoM, 444, 444S e ISO. 59

Figura 42 - Superfície do aço NeoM, após polarização anódica em solução PBS, naturalmente aerada a $37^{\circ} \mathrm{C}$. A) 2 dias de imersão B) 21 dias de imersão. 60 Figura 43 - Aço NeoM, após polarização anódica em solução PBS, naturalmente aerada a $37^{\circ} \mathrm{C}$. A) Processo de formação de pite em sua fase inicial. B) Maior aumento evidenciando a presença de um precipitado.

Figura 44 - Espectro de EDS da região do precipitado mostrado na Figura 43. ..61 
Figura 45 - Micrografias obtidas por MEV da superfície do aço AISI 444, polarizado anodicamente pela técnica potenciodinâmica cíclica, após 21 dias de imersão em solução PBS a $37{ }^{\circ} \mathrm{C}$. A) Como recebido (444); B) Solubilizado (444S).

Figura 46 - Micrografia por MEV de um precipitado do aço 444 polarizado anodicamente, após 21 dias de imersão em solução PBS a $37^{\circ} \mathrm{C}$. A) Região de precipitado; B) Espectro por EDS da região indicada.

Figura 47 - Micrografias obtidas por MEV do aço ISO 5832-1, polarizado anodicamente pela técnica potenciodinâmica, após 21 dias de imersão em solução PBS a $37^{\circ} \mathrm{C}$. A) Visão geral; B) Maior aumento da área indicada. .. 63 Figura 48 - Diagramas de impedância do aço ISO 5832-1 em solução PBS, naturalmente aerada e a $37^{\circ} \mathrm{C}$. A) Diagramas de Bode. B) Nyquist. 64

Figura 49 - Diagramas de impedância do aço AISI 444 (como recebido) em solução PBS, naturalmente aerada e a $37^{\circ} \mathrm{C}$. A) Diagramas de Bode. B) Nyquist 66

Figura 50 - Diagramas de impedância do aço AISI 444S (solubilizado), em solução PBS naturalmente aerada e a $37^{\circ} \mathrm{C}$. A) Diagramas de Bode. B) Nyquist.

Figura 51 - Diagramas de impedância do aço NeoM, em solução PBS naturalmente aerada e a $37^{\circ} \mathrm{C}$. A) Diagramas de Bode. B) Nyquist. 68

Figura 52 - Diagramas de Bode dos aços ISO, 444, 444S e NeoM, em solução PBS naturalmente aerada a $37^{\circ} \mathrm{C}$. A) 2 dias de imersão. B) 21 dias de imersão. 70

Figura 53 - Diagramas de Nyquist dos aços ISO, 444, 444S e NeoM, em solução PBS naturalmente aerada a $37^{\circ} \mathrm{C}$. A) 2 dias de imersão. B) 21 dias de imersão. 71

Figura 54 - Circuito elétrico equivalente proposto para caracterizar a camada passiva dos aços ISO, 444, 444S e NeoM (2 dias). 72

Figura 55 - Circuito elétrico equivalente proposto para caracterizar a camada passiva do aço NeoM, após 21 dias.

Figura 56 - Representação do modelo físico adotado para explicar o comportamento eletroquímico dos aços ensaiados, ajustado com duas constantes de tempo em série. .73 
Figura 57 - Representação do modelo físico adotado para explicar o comportamento eletroquímico do aço NeoM, ajustado com três constantes de tempo.

Figura 58 - Exemplo de método de extrapolação para determinação do potencial de banda plana. Curva experimental do aço NeoM após 21 dias de imersão.

Figura 59 - Gráficos de Mott-Schottky para o aço NeoM em solução PBS, naturalmente aerada a $37^{\circ} \mathrm{C}$. .78

Figura 60 - Valores da concentração de doadores de carga no filme passivo do NeoM, determinados a partir dos gráficos de Mott-Schottky da Figura 59, na região de potenciais entre $-0,4 \mathrm{~V}$ e $+0,5 \mathrm{~V}$.

Figura 61 - Valores da concentração de aceitadores de carga no filme passivo do aço NeoM, determinados a partir dos gráficos de Mott-Schottky da Figura 59, na região de potenciais entre $-1 \mathrm{~V}$ e $-0,4 \mathrm{~V}$.

Figura 62 - Valores da concentração de dopantes no filme passivo do aço NeoM, determinados a partir dos gráficos de Mott-Schottky (Figura 59).

Figura 63 - Gráficos de Mott-Schottky para o aço AISI 444 em solução PBS, naturalmente aerada a $37^{\circ} \mathrm{C}$.

Figura 64 - Valores da concentração de doadores de carga no filme passivo do aço AISI 444, determinados a partir dos gráficos de Mott-Schottky (Figura 63) na região de potenciais $>E_{b p}$.

Figura 65 - Valores da concentração de aceitadores de carga no filme passivo do aço 444, determinados a partir dos gráficos de Mott-Schottky (Figura 63) na região de potenciais $<\mathrm{E}_{\mathrm{bp}}$.

Figura 66 - Valores da concentração de dopantes no filme passivo do aço 444, determinados a partir dos gráficos de Mott-Schottky (Figura 63). 83

Figura 67 - Valores da concentração de doadores e aceitadores de carga no filme passivo sobre os aços 444 e NeoM.

Figura 68 - Variação do potencial de circuito aberto para os aços ISO 5832-1 e AISI 444, em condição de fresta, ao longo de 72 horas de imersão em solução PBS a $37^{\circ} \mathrm{C}$. 85

Figura 69 - Micrografias obtidas por MEV da superfície do aço ISO 5832-1, após 72 horas de imersão em solução PBS a $37^{\circ} \mathrm{C}$, em condição de fresta. A) 
Visão geral da amostra. B) Maior aumento da região em destaque. C) Maior aumento do ponto indicado pela seta.

Figura 70 - MEV da superfície do aço ISO após polimento. A) Imagem similar ao encontrado na amostra polarizada. B) Maior aumento da área em destaque.

Figura 71 - MEV da superfície do aço ISO 5832-1 após polimento. A) Inclusão. B) EDS da inclusão. 88

Figura 72 - Micrografias obtidas por MEV da superfície do aço AISI 444, após 72 horas de imersão em solução PBS a $37^{\circ} \mathrm{C}$, em condição de fresta. A) Visão geral da amostra. B) Maior aumento da região em destaque. C) Maior aumento do ponto indicado pela seta.

Figura 73 - Diagramas de Bode (A) e Nyquist (B) para os aços ISO 5832-1 e AISI 444 nos períodos de imersão de 2 e 7 dias em condição de fresta. .90

Figura 74 - Circuito elétrico equivalente proposto para caracterizar a camada passiva dos aços 444 e ISO, em condição de fresta.

Figura 75 - Curvas de polarização anódica potenciodinâmica cíclica, após 2 dias de imersão em solução PBS a $37^{\circ} \mathrm{C}$, em condição de fresta. 92

Figura 76 - Fotografias das amostras dos aços AISI 444 (A) e ISO 5832-1(B) após polarização anódica potenciodinâmica cíclica, com 2 dias de imersão em solução PBS naturalmente aerada a $37^{\circ} \mathrm{C}$, na condição de fresta. .93

Figura 77 - Aço AISI 444 após polarização em condição de fresta. A) Corrosão localizada próxima à fresta (ponto 1 da Figura 76A) com diâmetro aproximado de 400 micras. B) $\mathrm{MO}$ com maior aumento da área selecionada. .94

Figura 78 - Aço AISI 444 após polarização em condição de fresta. A) Corrosão localizada próxima à fresta (ponto 2 da Figura 76A) com comprimento aproximado de 70 micras. B) MO com maior aumento da área selecionada. 94 Figura 79 - Aço ISO 5832-1 após polarização em condição de fresta. A) Corrosão localizada (ponto 1 da Figura 76B), evidenciando a geometria da borda da fresta. B) MO com maior aumento da área selecionada. .95

Figura 80 - Aço ISO 5832-1 após polarização em condição de fresta. A) Áreas de corrosão localizada (ponto 2 da Figura 76B) acompanhando a borda da fresta. B) MO com maior aumento da área selecionada, mostrando região de corrosão localizada com comprimento aproximado de 350 micras. .95 
Figura 81 - Aço ISO 5832-1 após polarização em condição de fresta. A) Área de corrosão diferenciada no centro da amostra (ponto 3 da Figura 76B). B) MO com maior aumento da área selecionada. .95 


\section{LISTA DE ABREVIATURAS}

$\begin{array}{ll}\text { CEE } & \text { Circuito elétrico equivalente } \\ \varepsilon & \text { Constante dielétrica do filme passivo } \\ E_{b p} & \text { Potencial de banda plana } \\ E_{\text {corr }} & \text { Potencial de Corrosão } \\ E_{c} & \text { Potencial de pite } \\ E_{p} & \text { Potencial de proteção } \\ \text { EIE } & \text { Espectroscopia por Impedância Eletroquímica } \\ \mathrm{i}_{c o r r} & \text { Densidade de Corrente de Corrosão; } \\ \text { IRM } & \text { Imagem por Ressonância Magnética } \\ \text { MEM } & \text { Meio Mínimo Essencial de Eagle } \\ \text { MEV } & \text { Microscopia Eletrônica de Varredura } \\ \text { MO } & \text { Microscópio Óptico } \\ N_{A} & \text { Densidade de aceitadores de cargas de Mott-Schottky } \\ N_{D} & \text { Densidade de doadores de cargas de Mott-Schottky } \\ N_{q} & \text { Densidade de dopantes ou portadores de cargas obtidos pela } \\ & \text { técnica de Mott-Schottky } \\ \text { NdFeB } & \text { Liga magnética de Neodímio-Ferro-Boro } \\ \text { PBS } & \text { Solução Salina Tamponada por Fosfato } \\ \text { PRE } & \text { Pitting Resistance Equivalent } \\ \text { SUS } & \text { Nomenclatura para aços utilizada no Japão. } \\ X P S & \text { Espectroscopia Fotoelétrica por Raio-X } \\ Z & \text { Impedância }\end{array}$




\section{INTRODUÇÃO}

Existe uma diversidade de ligas metálicas amplamente utilizadas nas áreas médica e odontológica devido às suas propriedades físico-químicas. A interação destas ligas com o corpo humano exige destes materiais um bom desempenho mecânico quanto ao desgaste, resistência à corrosão em fluidos corpóreos, ausência de resposta imunológica, capacidade de osseointegração e ausência de ferromagnetismo, entre outros.

Os materiais com aplicações em áreas médicas, que formam uma interface com os sistemas biológicos, no intuito de tratar, crescer ou substituir, tecidos, órgãos ou funções corporais, são definidos como biomateriais (ORÉFICE et al. 2006, WILLIAMS, 1980 e 1987, HIROMOTO et al., 2002).

Os aços inoxidáveis são atualmente o grupo de biomateriais metálicos mais utilizados, correspondendo a mais de $50 \%$ do mercado total destes, sendo seguido pelas ligas de titânio e de cobalto (World Biomedical Metal Market, 2010). Nesta categoria, destaca-se o aço inoxidável austenítico ISO 5832-1 (ASTM F138) como o material mais utilizado na fabricação de próteses ortopédicas. Um dos requisitos desta norma é a ausência de ferromagnetismo, que pode causar o deslocamento da prótese, no caso do paciente ser submetido a exame de ressonância magnética, por exemplo.

Os aços ferríticos são naturalmente ferromagnéticos. Apesar disso, em algumas aplicações específicas, são utilizados como biomaterial. Como exemplos, tem-se as próteses odontológicas e faciais com conectores magnéticos e a fabricação de máquinas de diálise (1802 Datasheet, Sandvik).

Alguns tipos de aços inoxidáveis ferríticos têm mostrado resistência à corrosão, equivalente ou superior, a do aço inoxidável austenítico 316 e outras ligas austeníticas (ASSAMI e HASHIMOTO, 2003; CHIBA et al., 2000; DOWLING et al., 1999; $\mathrm{OH}$ et al., 2004; SUN et al., 1997). MALHEIRO et al. (2011) estudaram o aço inoxidável ferrítico AISI 444. Propuseram sua aplicação em um novo tipo de prótese ortopédica estimulada por campo magnético, cujas microtensões, provocadas pelo mesmo, promoveriam o crescimento ósseo. A composição química dos aços ferríticos, normalmente, contém pouco ou nenhum níquel, o que representa uma grande vantagem na redução do potencial alergênico e do custo de produção. Por outro lado, a propriedade magnética destes materiais faz com que tenham seu uso restrito, uma vez que há relutância 
em usar materiais ferromagnéticos como implantes permanentes. Dispositivos ferromagnéticos, conectados aos tecidos moles (clipes para oclusão de aneurisma cerebral, "shunts") e aparelhos eletrônicos implantados (marca-passo), são contraindicados para o exame de ressonância magnética, devido ao risco de se deslocarem ou induzirem corrente elétrica. (ELSTER E BURDETTE, 2001).

Os aços inoxidáveis ferríticos são empregados, na odontologia, para estabilizar próteses dentais (Figura 1) e faciais removíveis (Figura 2), bem como para fabricação de bráquetes ortodônticos. O sistema de conexão magnética, para próteses, consiste em uma unidade de retenção composta por duas partes que se unem, devido ao campo de atração. Como mostrado na Figura 1, este tipo de conexão é composta por um ímã permanente de terras raras $(A)$, fixado na prótese, e um conector protético $(B)$, parafusado ao implante $(C)$ e fabricado em liga ferromagnética. Diversos tipos de aços inoxidáveis ferríticos, como o SUS 444, SUS XM27 e SUS 447J1, foram testados com sucesso para confecção de conectores protéticos magnéticos (B) (TAKADA et al., 2005, NAKAMURA et al., 2008).

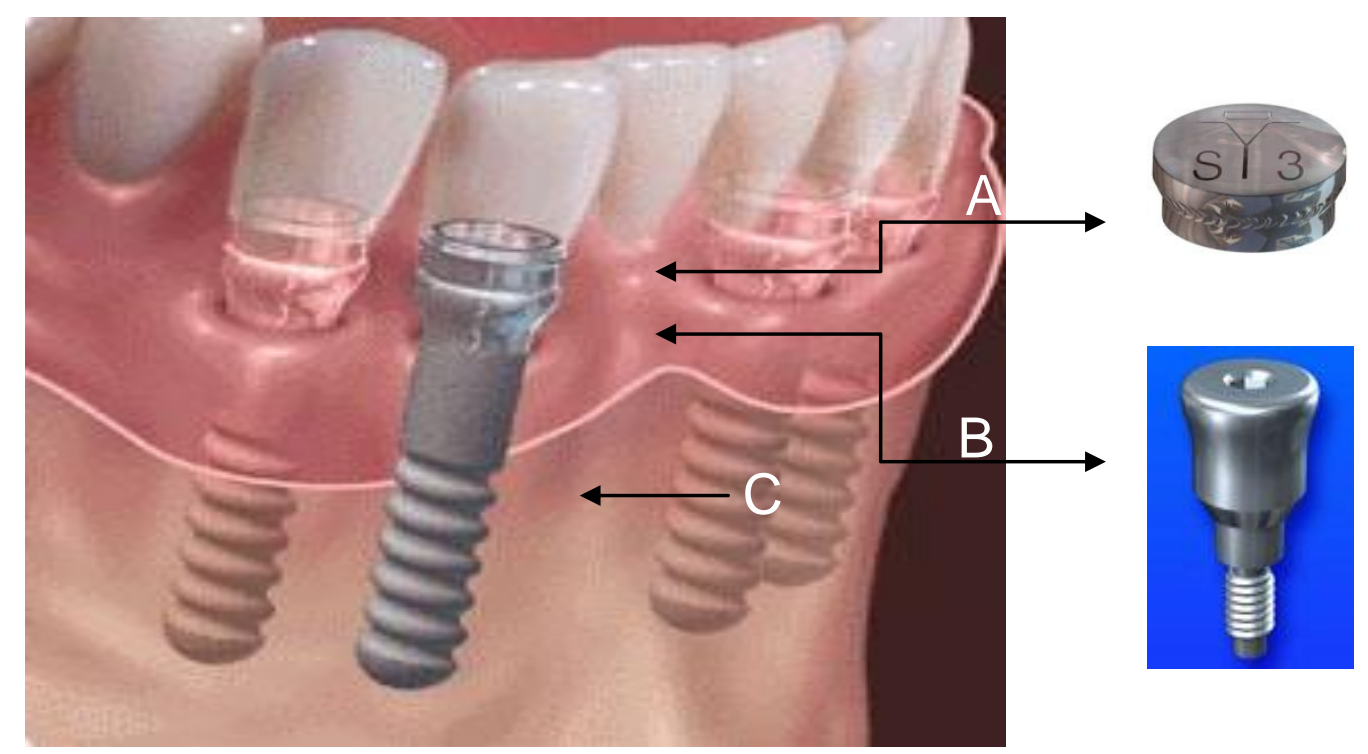

Figura 1 - Sistema magnético sobre implante. A) Imã; B) Conector protético; C) Implante. Fonte: Dyna Magnet Manual 


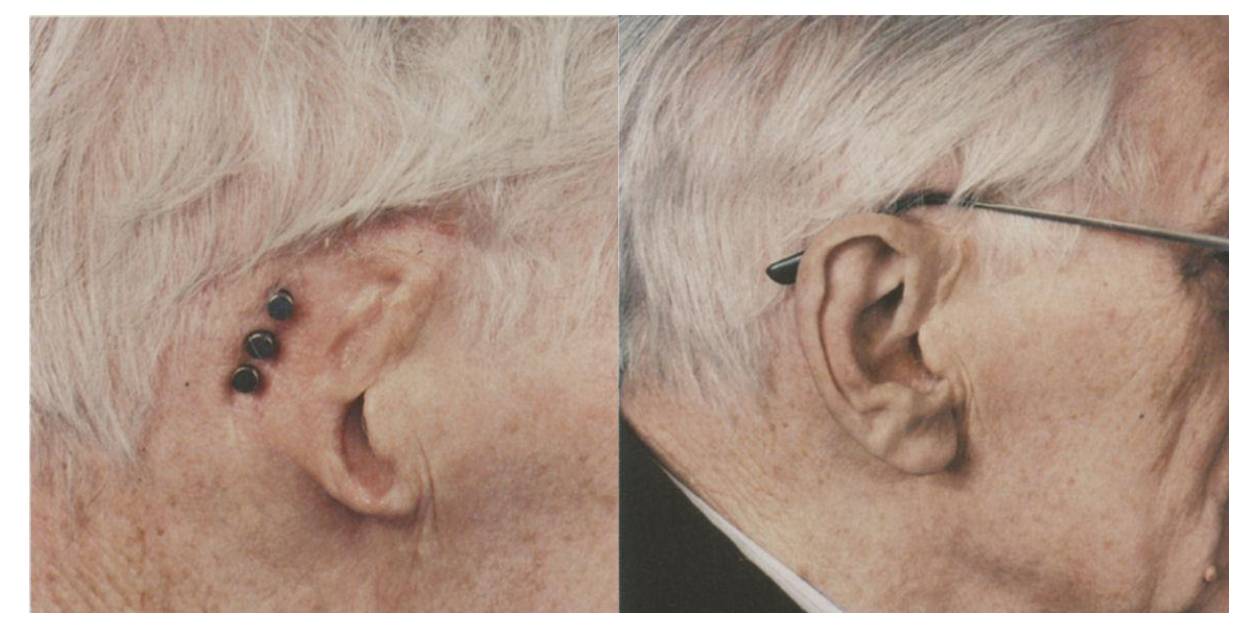

Figura 2 - Prótese auricular sobre implantes com retenção magnética. Fonte: THOMAS, 1995

Além dos conectores magnéticos, também são utilizados na Odontologia conectores por retenção mecânica, baseados no princípio de fixação por atrito ou pressão entre os componentes. Na comparação com os sistemas de próteses por retenção mecânica, a retenção magnética apresenta vantagens e desvantagens. Como vantagens podem ser citadas:

- Redução das forças laterais ou não axiais. Estas forças são prejudiciais ao tecido ósseo por induzir o processo de reabsorção. A superfície plana, entre o ímã e o conector protético, permite rotação durante a função, resultando em um melhor prognóstico (SAYGILI e SAHMALI, 1998).

- Na instalação do ímã, em próteses com múltiplos implantes, não há a necessidade de um eixo de inserção paralelo entre os componentes. (WALMSLEY, 2002).

- Maior facilidade de colocação e higienização da prótese, principalmente em pacientes com algum tipo de distúrbio neuro-motor (Parkinsonianos, por exemplo).

O custo, relativamente alto para os padrões nacionais, e a baixa resistência à corrosão dos ímãs de $\mathrm{NdFeB}$ são citados como as principais desvantagens (KITSUGI et al., 1992).

Trabalhos publicados por ASSAMI E HASHIMOTO (2003) e por DOWLING et al. (1999) indicaram boa resistência à corrosão do aço inoxidável AISI 444. Outros autores, como CIAPETTI et al. (2005), FLORES et al. (2004), HERTING et al. (2007) e JANSEN et al. (1992), estudaram a biocompatibilidade 
de aços inoxidáveis ferríticos, sugerindo uma boa resposta tecidual sem evidência de inflamação ou reações citotóxicas.

O aço inoxidável ferrítico AISI 444 vem sendo proposto na literatura como um possível biomaterial, especialmente para a fabricação de conectores protéticos ferromagnéticos. Porém, são necessários mais estudos quanto à biocompatibilidade, à resistência à corrosão em meios fisiológicos simulados e à força de retenção magnética.

O custo dos componentes para a confecçào de próteses magnéticas, comercializados no Brasil é alto devido aos materiais serem todos importados. O aço AISI 444 indica ser um subtituto que poderia reduzir sensivelmete este custo.

A maioria das publicações, sobre corrosão de biomateriais, utilizou células de corrosão que não simulam as possíveis condições mais agressivas, às quais o material estará sujeito. Dentre elas, tem-se a condição de corrosão em frestas. As metodologias normatizadas para o estudo da condição de fresta acabam por dificultar ou limitar a execusão dos ensaios. 


\section{OBJETIVOS E JUSTIFICATIVAS}

A condição de aeração natural para estudo de biomateriais em contato com o meio corpóreo, como as próteses ortopédicas e dentais, não permite simular o comportamento destes materiais, frente à corrosão, em condições reais de uso. Um biomaterial metálico, empregado na confecção de uma prótese dental, está sujeito a condições muito mais agressivas do que a simulada por uma célula eletroquímica aerada. Além do que, a condição aerada, algumas vezes, não permite diferenciar dois materiais passivos e escolher qual é o mais indicado para determinada aplicação. Considerando que a condição mais agressiva é aquela com maior probabilidade de iniciar e propagar os processos corrosivos, o seu estudo é de extrema importância. Buscar condições limítrofes é fundamental para uma indicação segura de um futuro biomaterial. Estudos de corrosão em condição de frestas podem contribuir muito para isto.

Os componentes de próteses para conexões magnéticas, vendidos no Brasil, são todos importados, o que eleva muito o seu custo. Um material substituto nacional pode reduzir este custo, o que viabilizará que um maior número de pacientes tenha condição financeira de arcar com o tratamento.

Este trabalho teve como objetivos:

- Estudar o comportamento do aço inoxidável ferrítico AISI 444 frente à citotoxicidade in vitro e à força de retenção magnética.

- Comparar a resistência à corrosão do aço AISI 444 com a de outros biomateriais, por meio de ensaios eletroquímicos em condições aerada e em fresta.

- Desenvolver um novo arranjo experimental para os ensaios eletroquímicos em condição de fresta. 


\section{REVISÃO DA LITERATURA}

\subsection{Sistema de fixação magnética para próteses}

FEDERICK, em 1976, foi um dos primeiros autores a propor a fixação de próteses por magnetismo. Ele descreveu a confecção de uma prótese com conexão magnética para um paciente operado de um carcinoma infiltrado em maxila, que havia perdido parte do palato e da órbita direita. A prótese foi confeccionada em duas partes, sendo uma colocada pela boca e a outra pela órbita. A união entre elas ocorria devido à atração entre os ímãs posicionados em cada segmento da prótese.

GILLINGS (1983), após acompanhar 48 casos de próteses magnéticas, durante quatro anos, concluiu que esta pode ser uma alternativa mais econômica ao invés de optar pela extração dental.

HIGHTON et al. (1988) conduziram experimentos, realizando ciclos de retirada e colocação de próteses sobre implante, utilizando um equipamento para ensaio in vitro. Observaram que, mesmo após 44 mil ciclos de retirada e recolocação da prótese, os ímãs não perdiam força retentiva, diferentemente dos sistemas baseados na retenção por atrito. Concluíram que os ímãs possuem uma força de retenção inferior aos sistemas mecânicos, porém ainda suficiente para retenção da prótese. A principal vantagem no uso dos magnetos é o fato de não sobrecarregarem os implantes ou o rebordo ósseo.

DAVIS et al. (1996) selecionaram 12 pacientes e, em cada um deles, instalaram 2 implantes mandibulares e confeccionaram próteses fixadas por imãs. Durante o acompanhamento, por três anos, as falhas mais encontradas foram o desaparafusamento do pilar protético ferromagnético e a perda de magnetização do ímã. Esta última ocorreu devido à perda de integridade da cápsula de proteção, o que permitiu a corrosão da liga magnética. Todos os pacientes avaliaram satisfatoriamente a prótese, após três anos de acompanhamento.

As próteses magnéticas são indicadas a pacientes com microstomia (abertura da boca reduzida) devido à dificuldade de inseri-la dentro da boca. WATANABE et al. (2002) relataram um caso clínico de paciente edentulo com microstomia, o que impossibilitava o uso de qualquer tipo de prótese total. Foram confeccionadas duas próteses totais articuladas, as quais se dobravam para 
permitir a passagem pelos lábios (Figura 3). Quando dentro da boca, foi encaixado um segmento anterior fixado por imãs o qual matém a prótese aberta.

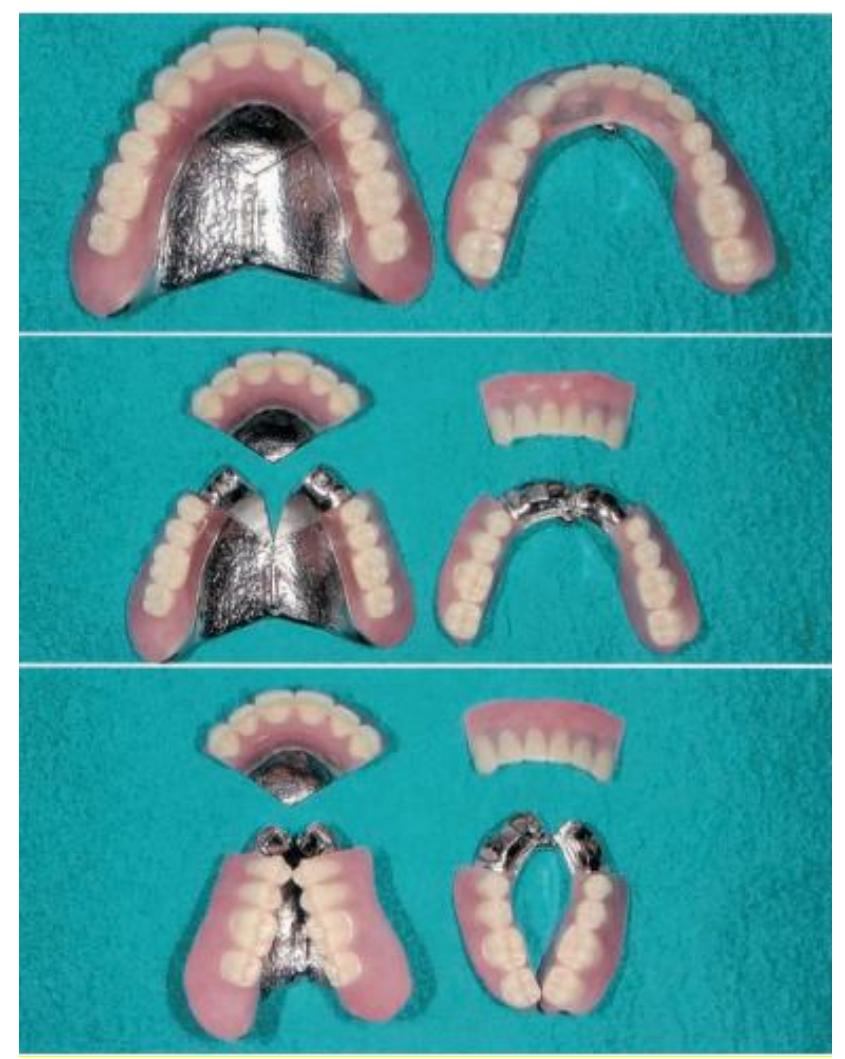

Figura 3 - Próteses totais superiores e inferiores com articulação e travamento anterior por magnetos. Fonte: WATANABE et al. (2002).

Quando o paciente sofre perda do controle muscular, é muito difícil a colocação e retirada de próteses com sistemas mecânicos. FREDERICK et al. (2004) acompanharam o caso clínico de um paciente portador do mal de Parkinson, utilizando uma prótese total mandibular com retenção magnética. Concluiram que a utilização de conectores magnéticos facilitou a colocação e a higienização da prótese.

Além das próteses intrabucais, os sistemas magnéticos também são utilizados em próteses faciais instaladas sobre implantes craniofaciais. THOMAS (1995) relatou a utilização de próteses auriculares com conexões magnéticas sobre implantes faciais. As principais vantagens, comparadas com sistema convencional de conexão barra-clipe, foram: fácil higienização devido ao melhor acesso aos implantes; fácil colocação da prótese; redução da tensão sobre os implantes e tecido ósseo devido à dissipação das forças laterais.

CHUNG et al. (2003) descreveram a confecção de uma prótese auricular sobre implantes craniofaciais utilizando uma subestrutura fundida, na 
qual foram instalados conectores magnéticos. Concluíram que esta técnica simplificava os procedimentos clínicos e laboratoriais, além de reduzir o custo da prótese.

\subsection{Citotoxicidade in vitro}

A biocompatibilidade é um dos fatores mais importantes na escolha de um novo biomaterial. Ela busca descrever as respostas do organismo e consequentes reações adversas causadas pela presença do material em questão (WILLIAMS, 1980, ORÉFICE et al., 2006).

Segundo o Órgão Internacional de Padronização (International Standard Organization - ISO), norma ISO10993 parte 1, o ensaio de citotoxicidade in vitro é considerado o primeiro método para avaliação da biocompatibilidade, pois possibilita a distinção entre materiais tóxicos e não tóxicos de forma relativamente rápida e de baixo custo. Após comprovada a não citotoxicidade, o material poderá ser submetido a ensaios em animais de laboratório. A resposta tóxica de um material é, normalmente, ocasionada pela liberação de um elemento ou composto químico em quantidades suficientes para matar as células, devido à inibição das vias metabólicas, alterações na permeabilidade da membrana celular, inibição enzimática, entre outras.

ROGERO et al. (2003) padronizaram uma metodologia para ensaios de citotoxicidade in vitro baseada na ISO 10993-5 (1992). Nesta metodologia, extratos dos metais estudados são colocados em contato com uma cultura celular de mamíferos com linhagem pré-estabelecida. Após um período de incubação, é adicionado o corante supravital vermelho neutro, que será incorporado pelas células viáveis. $O$ corante vermelho neutro é solúvel em água e atravessa a membrana celular, ficando armazenado nos lisossomos, dentro da célula. A presença de possíveis substâncias tóxicas, nos extratos obtidos dos metais, pode provocar danos às membranas celulares, ocasionando redução na captura do corante. Isto permite distinguir as células vivas (viáveis), as danificadas e as mortas. A fim de que não seja necessária a contagem individual das células, utiliza-se um espectrofotômetro para medir a densidade óptica e relacionar com a quantidade de corante incorporado pela população de células. Os valores obtidos são utilizados para calcular a média de viabilidade celular e comparar com o grupo de controle positivo, determinando o índice de citotoxicidade $\mathrm{IC}_{50 \%}$. Este índice representa a concentração do extrato que provoca dano ou morte em 50\% 
da população de células no ensaio. As curvas de viabilidade dos extratos estudados devem estar acima do $\mathrm{IC}_{50 \%}$ para serem considerados não citotóxicos.

Estudos de biocompatibilidade de aços inoxidáveis ferríticos sugerem uma boa resposta tecidual, sem evidência de reações inflamatórias ou citotóxicas.

CIAPETTI et al. (2005) estudaram os efeitos biológicos causados por partículas de uma nova liga ferrítica (FeCrAl) nas células osteoblásticas e macrófagos. Os resultados foram comparados com a resposta celular para a liga de Ti6Al4V. A viabilidade e proliferação dos osteoblastos e macrófagos não foram significativamente afetadas pela presença destas partículas. Foi confirmada a liberação de íons de cromo e alumínio no meio, porém não foi encontrada uma correlação direta com o comportamento celular. Concluíram que esta nova liga não apresentou citotoxicidade in vitro e, devido às suas características químicas e mecânicas, deve ser considerada para aplicação em implantes. Contudo, segundo estes pesquisadores, estes estudos devem ser continuados.

ROGERO et al. (2006) realizaram ensaios, nos quais diferentes materiais ficaram imersos em meio mínimo essencial de Eagle (MEM) a $37^{\circ} \mathrm{C}$, durante 10 dias. Após este período, foram obtidos os extratos dos produtos de corrosão das diferentes ligas metálicas, dentre elas o aço inoxidável ferrítico AISI 444. Os resultados do teste de citotoxicidade in vitro, pelo método de incorporação do vermelho neutro, revelaram ausência de lesão celular associada ao aço AISI 444.

HERTING et al. (2007) estudaram a taxa de liberação de íons de sete tipos de aços inoxidáveis expostos a dois fluidos corporais sintéticos. Foram investigados dois aços inoxidáveis ferríticos (AISI 409 e AISI 430), um duplex (2205) e quatro austeníticos (AISI 201, AISI 304, AISI 310 e AISI 316L). Concluíram que, para todos os materiais testados, a taxa de liberação dos elementos constituintes de liga foi $<5 \mu \mathrm{g} \mathrm{cm}-2 /$ semana, considerado um valor baixo.

GRANCHI et al. (1998) avaliaram os efeitos dos íons metálicos, decorrentes da corrosão de implantes em uma cultura de células sanguíneas mononucleadas. Foram empregados extratos de cromo, níquel e cobalto, por serem os elementos químicos mais comuns nas ligas metálicas utilizadas para a fabricação de implantes ortopédicos. Além disso, os produtos de corrosão destes elementos estão, geralmente, associados às reações teciduais inflamatórias. Concluíram que os extratos de cromo, níquel e cobalto induzem citotoxicidade. 
Esta ocorrência depende da concentração e tipo do íon metálico, assim como do tempo de contato com as células mononucleadas. Grandes quantidades de níquel e cobalto causam necrose celular. As liberações de cromo e de quantidades limitadas de níquel e cobalto ocasionam, principalmente, apoptose celular, fenômeno menos sério do ponto de vista biológico, porque permite a adaptação dos tecidos ao implante.

\subsection{Exames de imagem por ressonância magnética}

A ausência de fase ferromagnética no material metálico é uma exigência para que os pacientes portadores de implantes metálicos possam ser submetidos a exame por ressonância magnética (IRM).

SHELLOCK et al. $(1988,1992,1993,2002)$ conduziram diversos estudos, nos quais mediram o movimento ou deflexão de diversos implantes ortopédicos, quando submetidos a altos campos magnéticos produzidos por equipamentos de IRM. Concluiram que não foi possível mensurar qualquer movimento dos implantes fabricados em ligas de titânio, de cobalto e aços inoxidáveis.

IIMURO (1994) publicou um artigo sobre a presença de distorções de imagem, em exames por IRM, provocados por conectores ferromagnéticos fixados aos implantes dentários. Observou que os conectores provocam uma alteração de imagem severa, porém localizada. Concluiu que as distorções nas imagens não impossibilitam a utilização da IRM como ferramenta de diagnóstico, desde que a área a ser observada não esteja muito próxima ao conector. Para DEVGE et al. (1997), os conectores magnéticos, fixados aos implantes, provocaram uma grande distorção das imagens ao redor dos mesmos. Concluíram que estes devem ser removidos para uma melhor visualização de áreas próximas aos implantes.

Conforme observado por IIMURO (1994) e DEVGE et al. (1997), o elevado campo magnético, produzido pelo equipamento de IRM, torna inviável a utilização de materiais ferromagnéticos em implantes ortopédicos (NEW et al, 1983, WOODS, 2002). Contudo, em próteses odontológicas removíveis, com conexão magnética, não haveria grandes complicações, devido ao seu tamanho reduzido e possibilidade de retirada prévia. 


\subsection{Aços inoxidáveis}

Os aços inoxidáveis são ligas ferrosas que apresentam um teor mínimo de $12 \%$ de cromo, sendo comumente também adicionado o níquel (SEDRIKS, 1996). Além dos elementos principais ( $\mathrm{Fe}, \mathrm{Cr}$ e Ni), os aços inoxidáveis podem possuir o carbono (C), o silício ( $\mathrm{Si}$ ), o manganês (Mn), o molibdênio (Mo), o nitrogênio $(\mathrm{N})$, entre outros. Estes elementos são resultantes do processo de produção do aço ou adicionados, propositalmente, para modificar algumas propriedades mecânicas. Entre os elementos indesejáveis, em grandes quantidades, podem ser citados o oxigênio $(\mathrm{O})$, o fósforo $(\mathrm{P})$ e o enxofre $(\mathrm{S})$ (ASM, 1990; PICKERING, 1976). O elemento de liga Cr é o principal responsável pela resistência à corrosão destes aços. Segundo a série eletroquímica, o cromo é menos resistente à oxidação do que o ferro e, quando em contato com o meio oxidante, uma camada superficial de óxido de cromo, altamente estável e resistente a muitos meios corrosivos, é rapidamente formada (MODENESI, 2001).

Os aços inoxidáveis austeníticos especiais apresentam na sua composição um teor mínimo de $17 \%$ de cromo e altos teores de elementos de liga, como níquel e molibdênio. Pequenas adições de manganês e nitrogênio substituem parcialmente o níquel, agindo como estabilizadores da estrutura austenítica. O principal elemento responsável pela resistência à corrosão por pite é o cromo. Entretanto, o molibdênio também aumenta a resistência à corrosão por este tipo de ataque localizado. Os aços inoxidáveis austeníticos apresentam estrutura cúbica de face centrada (cfc). Esta estrutura confere ao material propriedades mecânicas adequadas para aplicação em próteses ortopédicas, elevada resistência à corrosão e ausência de fases ferromagnéticas na condição solubilizada (VILLAMIL et al., 2002).

A utilização de aços inoxidáveis para a fabricação de implantes ortopédicos vem sendo feita há muitas décadas (MEARS, 1999, RONDELLI et al. 2005). Nesta categoria, destaca-se o aço inoxidável ISO 5832-1 (ASTM F139), material de escolha na fabricação dos implantes ortopédicos da rede hospitalar pública. A liga ISO-5832-1 é um aço inoxidável austenítico, não magnético (quando não deformado), à base de cromo-níquel-molibdênio e com teor extra baixo de carbono. Atualmente, este é o biomaterial metálico mais utilizado na fabricação de próteses ortopédicas e dispositivos médicos (ANTUNES, 2006). O elevado emprego deste material deve-se à combinação de propriedades mecânicas, resistência à corrosão, biocompatibilidade e custo relativamente 
baixo, quando comparado com outros biomateriais metálicos. Dentre as aplicações, incluem-se a fabricação de juntas artificiais, placas para fixação de fraturas ósseas, stents, entre outras. (SUMITA et al., 2000).

Os aços inoxidáveis ferríticos são ligas à base de ferro, contendo entre 12 e $30 \%$ de cromo e, em algumas formulações, com adição de molibdênio. A presença do Mo não só aumenta o potencial de pite, como diminui a densidade de corrente crítica e o primeiro potencial de passivação, o que facilita a formação do filme passivo. (SEDRIKS, 1996). Adições de nióbio e titânio previnem a precipitação de carbonetos de cromo, o que aumenta a resistência à corrosão intergranular (FOLKHARD, 1988).

O aço inoxidável AISI 444 representa a terceira geração de aços inoxidáveis ferríticos produzidos a partir da década de 70. A fabricação deste tipo de aço usufrui de técnicas mais eficientes de descarbonetação, possibilitando a produção de um aço com teores de carbono e nitrogênio da ordem de $0,02 \%$ ou até mais baixos. Estes aços são estabilizados com titânio ou nióbio e adicionados de molibdênio. O nióbio e titânio funcionam como estabilizadores da ferrita e são fortes formadores de carbonetos e nitretos (ROSSEL, 1999). O aço inoxidável ferrítico AISI 444 é amplamente usado na indústria química e petroquímica, devido à sua elevada resistência à corrosão localizada (principalmente corrosão sob tensão). Entretanto, os aços inoxidáveis ferríticos são suscetíveis à fragilização devido ao crescimento de grão e formação de fase sigma. TAVARES et al.(2008) avaliaram este material no tocante às mudanças microestruturais oriundas do envelhecimento na faixa de temperaturas de 560 a $800^{\circ} \mathrm{C}$ e o seu efeito nas propriedades mecânicas e magnéticas. Ficou evidenciado que este material não está sujeito à formação de fase sigma. Na faixa de temperaturas avaliada, houve a formação de precipitados ricos em Mo, como $\mathrm{Fe}_{2} \mathrm{Mo}$ e FeMoSi. A queda na dureza obtida foi relacionada ao aumento no tamanho de grão. A precipitação de fases Fe-Mo não afetou a magnetização de saturação deste material em questão.

A família dos aços inoxidáveis férricos (série 400) e suas características de composição química são apresentadas na Figura 4. 


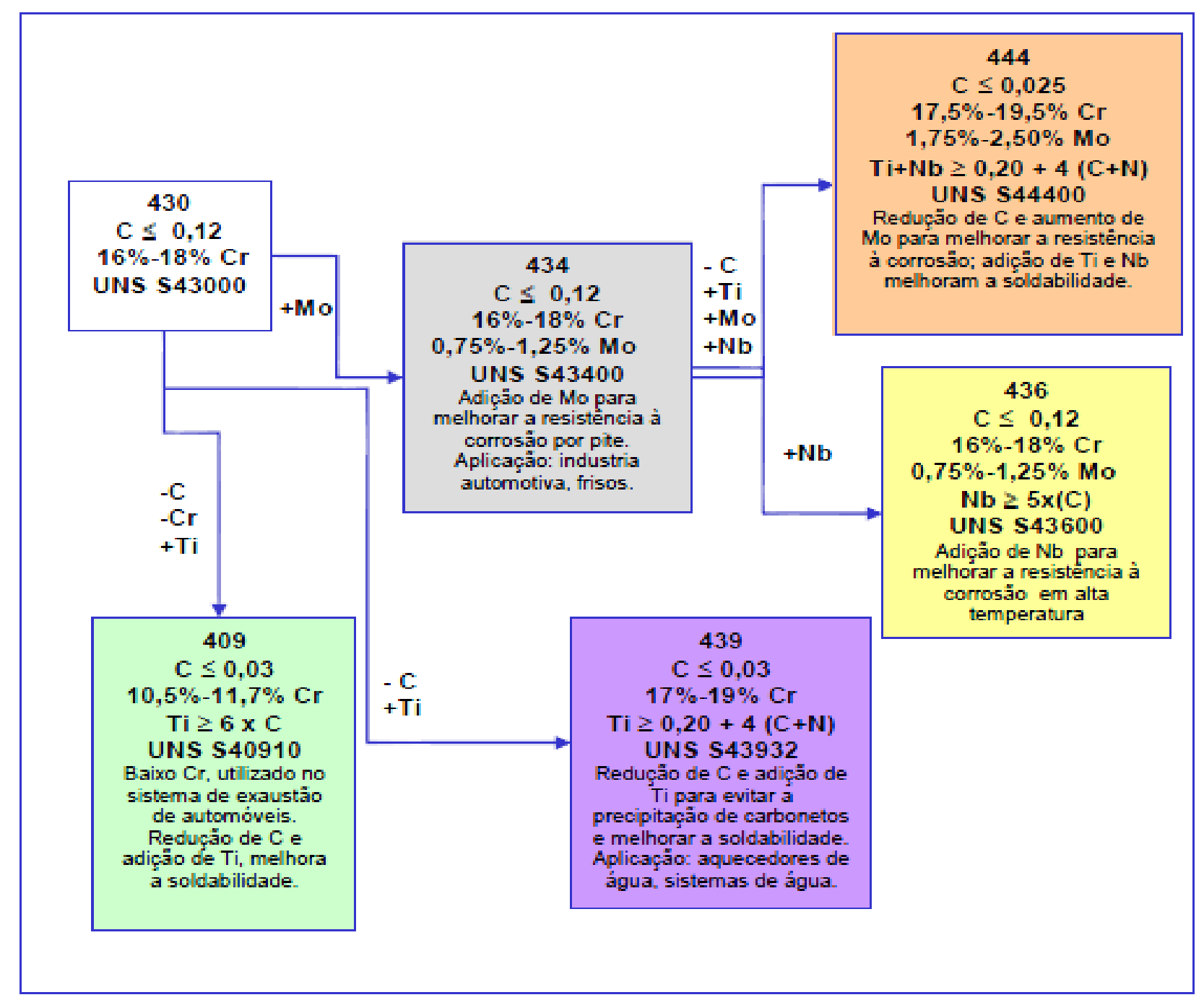

Figura 4 - Família dos aços inoxidáveis ferríticos - série 400. (ASTM A240/A240M, 2003) (SEDRIKS, 1996) Fonte: BOTTON, 2008.

\subsection{Corrosão de ligas metálicas e técnicas eletroquímicas}

O processo de corrosão é definido como a deterioração de um material por ação química ou eletroquímica do meio ambiente, associada ou não a esforços mecânicos (GENTIL, 1996). Para os aços inoxidáveis, em alguns meios, os compostos resultantes deste processo formam uma película de proteção, conhecida como camada passiva. Segundo diversos autores (CASTLE e CLAYTON, 1977, GINESAN e SMITH, 1988, HAKIKI et al, 1995, DA CUNHA BELO et al., 1998, HAKIKI e DA CUNHA BELO, 1998, BOJINOV et al., 1999, MARTINI e MULLER, 2000, MONTEMOR et al., 2000), o filme passivo é formado por óxidos de caráter duplex, composto principalmente de óxidos/hidróxidos de ferro e óxido de cromo. Segundo MILOSEV (2002), a camada interna do filme, próxima da interface metal/filme, contém principalmente óxido de cromo, enquanto a camada mais externa, próxima da interface filme/eletrólito, possui 
maior concentração de óxidos/hidróxidos de ferro. Dependendo da liga metálica, também estarão presentes outros óxidos, como o de níquel e de molibdênio, porém em menor quantidade.

A estabilidade de um filme de óxido é investigada em função do processo de dissolução, que é causado devido à ocorrência da transferência de íons no interior do filme. Diversos são os fatores que influenciam no processo de dissolução, como a sua estrutura, contorno dos grãos, porosidade, inclusões, além de vários outros (SCHULTZE e LOHRENGEL, 2000). Ainda, segundo os autores, há a influência dos íons cloreto na corrosão por pite, que pode ser explicada por dois mecanismos. No primeiro, a difusão de cloreto no óxido provoca instabilidade do mesmo, causando dissolução ativa. No segundo a adsorção de íons cloreto provoca tensões internas no filme, ocasionando sua quebra. Em ambas as situações, após a quebra do filme passivo, os íons cloreto adsorvem no metal, acelerando a dissolução ativa.

Segundo SATO (1990), a presença de ânions, particularmente os halogenetos, pode promover a quebra do filme. $O$ autor propõe três diferentes mecanismos de quebra do filme: mecânico, eletrônico e iônico. O processo mecânico ocorre devido à introdução de microtrincas, ocasionadas pelas tensões internas durante o crescimento do filme. A quebra do filme passivo, pelo mecanismo eletrônico, é provocada pela corrente eletrônica produzida, presumivelmente, somente em filmes espessos. Durante o processo de oxidação anódica, os ânions do eletrólito penetram no filme agindo como doadores de impurezas, ocasionando um aumento nos níveis de energia dos elétrons do óxido. Em filmes espessos, estes elétrons ganham energia suficiente para serem acelerados, provocando uma avalanche eletrônica que resulta na destruição localizada do óxido superficial. $O$ processo iônico ocorre em função da competição por adsorção, na interface óxido/eletrólito, entre íons hidroxila e ânions agressivos, como o cloreto $\left(\mathrm{Cl}^{-}\right)$. Os íons $\mathrm{Cl}^{-}$adsorvem no filme, causando sua dissolução ou produzindo lacunas de íons metálicos, que migram para formar uma lacuna condensada na interface metal/óxido. Esta lacuna pode induzir tensões mecânicas suficientes para a formação de microtrincas, as quais acabam ocasionando a quebra do filme passivo. Por fim, ocorre a exposição de uma pequena área do substrato metálico ao eletrólito, preferencialmente, em regiões de defeitos superficiais, tais como inclusões não metálicas. 
No Japão, os aços inoxidáveis são classificados segundo a norma JIS (Japanese Industrial Standards). Para os materiais abordados neste trabalho a equivalência desta, com as normas UNS e AISI, é mostrada na Tabela 1.

Tabela 1 - Equivalência da norma JIS com as normas UNS e AISI para os aços citados neste trabalho.

\begin{tabular}{|l|c|c|}
\hline \multicolumn{1}{|c|}{ JIS } & UNS & AISI \\
\hline SUS 316 & S31600 & 316 \\
\hline SUS 316L & S31603 & $316 \mathrm{~L}$ \\
\hline SUS 444 & S44400 & 444 \\
\hline SUS 447J1 & S44700 & - \\
\hline SUS XM27 & S44627 & - \\
\hline
\end{tabular}

OKUNO et al. (2002) estudaram a resistência à corrosão de aços inoxidáveis ferríticos utilizados para confecção do conector ferromagnético de próteses odontológicas. Os materiais testados foram os aços SUS 444 e SUS 447J1 (aço experimental), tendo como referência o aço inoxidável SUS 316L. O estudo eletroquímico foi feito por meio de curvas de polarização potenciodinâmica e monitoração do potencial de circuito aberto, em solução de $0,9 \%$ de $\mathrm{NaCl}$ a 37 oC. Os resultados mostraram que os aços inoxidáveis estudados apresentaram resistência à corrosão por pite mais elevada que o aço SUS $316 \mathrm{~L}$ (material de controle), sendo que o aço SUS 447J1 foi superior ao SUS 444.

TAKADA et al. (2007), publicaram um artigo indicando os principais aços ferríticos utilizados na produção dos conectores dentais ferromagnéticos (Tabela 2). Estes materiais foram estudados, eletroquimicamente, por meio de curvas de polarização, em meios contendo $0,9 \% \mathrm{NaCl}$ e $1 \%$ de ácido lático, após 24 horas de imersão no eletrólito a $37^{\circ} \mathrm{C}$. As curvas de polarização, anódicas e catódicas, mostraram que os potenciais de corrosão de todos os aços mantiveram-se dentro da região passiva. Os aços SUS XM27 e SUS 447J1 apresentaram potencial de pite ao redor de $+1200 \mathrm{mV}_{\text {Ecs. }}$ O potencial de pite do aço SUS $444\left(+500 \mathrm{mV}_{\mathrm{Ecs}}\right)$ foi ligeiramente superior ao do SUS $316 \mathrm{~L}(+400$ $m V_{E c s}$ ). Concluíram que os três aços inoxidáveis testados possuem resistência à corrosão superior ao SUS $316 \mathrm{~L}$ e, portanto, podem ser utilizados com segurança na fabricação de componentes para próteses magnéticas. 
Tabela 2 - Composição química (\% em massa) dos aços utilizados por TAKADA et al. (2007).

\begin{tabular}{lcccc}
\hline & $\mathbf{C r}$ & $\mathbf{F e}$ & Mo & $\mathbf{~ N i}$ \\
\hline SUS 444 & 19 & $>79$ & 2,0 & 0,18 \\
\hline SUS 447J1 & 30 & $>67$ & 2,0 & 0,20 \\
\hline SUS XM27 & 26 & $>72$ & 1,0 & 0,17 \\
\hline SUS 316L & $16-18$ & $>65$ & 2,0 & 13,5 \\
\hline
\end{tabular}

3.5.1 Espectroscopia por impedância eletroquímica (EIE) e circuitos elétricos equivalentes (CEE)

A técnica de EIE é muito utilizada para avaliar a resistência à corrosão dos filmes passivos por ser não destrutiva, permitindo um estudo longitudinal da mesma amostra.

Os diagramas de espectroscopia de impedância eletroquíca (EIE) podem ser modelados por um circuito elétrico equivalente (CEE), que são associados ao modelo físico do sistema eletroquímico em estudo. Os circuitos elétricos equivalentes utilizam uma combinação de resistores, capacitores, elementos de fase constante (CPE) e de Warburg. O elemento de fase constante (CPE) substitui o capacitor ideal devido a não idealidade do sistema eletroquímico real. A impedância desse elemento $\left(Z_{\mathrm{CPE}}\right)$ é dada pela seguinte relação:

$$
Z_{C P E}=\left(\frac{1}{Y_{0}}\right)(j \omega)^{-n}
$$

Equação 1

Na Equação $1, j=\sqrt{ }-1, \omega$ é a frequência angular $(\omega=2 \pi f$, sendo $f$ a frequência), $Y_{0}$ e $n$ são constantes do CPE e representam, respectivamente, as características superficiais das espécies eletroativas independentes e a distribuição não uniforme de corrente, devido à rugosidade e imperfeições superficiais (MATINI e MULLER, 2000). Para $n=1, Y_{0}=C$, logo o CPE é representado por um capacitor ideal (C). Se $\mathrm{n}=0$, o CPE é um resistor puro (LUI et al., 2003).

Segundo BONORA et al. (1996), o modelo proposto deve conter o menor número possível de componentes dentro de um erro aceitável. Os elementos propostos devem ter um significado físico claro quanto às propriedades do sistema que podem gerar o tipo de resposta elétrica obtida. Diversos modelos são propostos para explicar as características físicas da camada superficial de diferentes ligas metálicas e, alguns destes, estão representados na Figura 5. 
A)
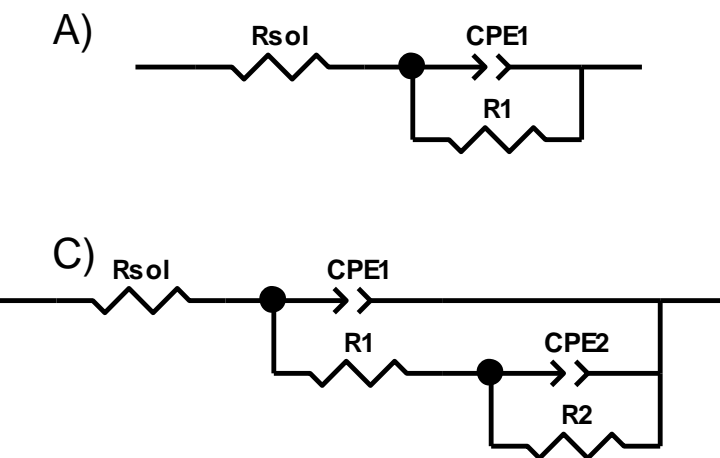
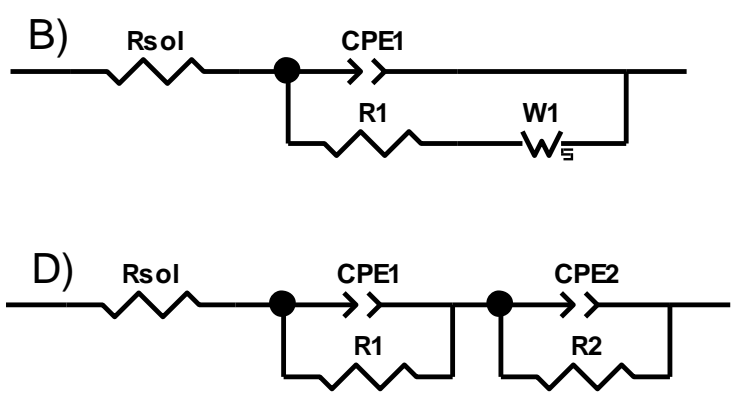

Figura 5 - Circuitos elétricos equivalentes propostos para caracterizar a camada superficial de diferentes ligas metálicas (AZUMI et al., 1986, BUNDY et al., 1993, GE et al., 2001 HIROMOTO et al, 2002, LIU et al., 2003, ANTUNES, 2006, TERADA, 2008).

O CEE ilustrado na Figura 5A é proposto para representar um filme simples, no qual ocorre adsorção acompanhada por transferência de carga. É composto pela resistência da solução $\left(R_{\text {sol }}\right)$ em série com a resistência $\left(R_{1}\right)$ e a capacitância ( $\mathrm{CPE}_{1}$ ) do filme, (GE et al., 2001 e WOLYNEC, 2003). A introdução de uma impedância de Warburg $\left(W_{1}\right)$, em série com a resistência de transferência de carga $\left(R_{1}\right)$, sugere a difusão de íons metálicos e lacunas de oxigênio no filme (POLO, et al., 2002)(Figura 5B). O circuito da Figura 5C propõe uma constante $R_{2}-C P E_{2}$ em série com a resistência do primeiro elemento $R_{1}-C P E_{1}$. É utilizado para explicar processos corrosivos em materiais com uma camada porosa ou com defeitos, associada a uma camada barreira ou compacta, como no caso de filmes passivos sobre ligas de titânio (ASSIS, 2006).

O circuito da Figura 5D mostra a resistência da solução $\left(R_{\text {sol }}\right)$ em série com dois elementos R-CPE. Segundo GE et al.(2001) $R_{1}$ e CPE $E_{1}$ representam a resistência e a capacitância da interface filme/solução, enquanto $R_{2}$ e $C P E_{2}$ correspondem à resistência e capacitância do filme passivo. Para HIROMOTO et al. (2002) $R_{1}$ e CPE $E_{1}$ representam a resistência e a capacitância da camada de adsorção bimolecualr, enquanto $R_{2}$ e $C P E_{2}$ correspondem à resistência e capacitância da camada de óxido.

HIROMOTO et al. (2002) utilizaram a técnica de EIE para estudar as reações entre a interface do titânio e diferentes meios biológicos simulados contendo proteinas e linhagens celulares. Os diagramas de EIE foram ajustados com os modelos de CEE da Figura $5 \mathrm{~A}$ e D. Sugeriram haver interações entre as superfícies metálicas e os meios utilizados. A camada de adsorção biomolecular, 
contendo proteínas e células, foi formada sobre o titânio e funcionou como um capacitor, prevenindo a difusão de moléculas.

GOPI et al. (2013) estudaram a suscetibilidade à corrosão do aço inoxidável austenítico AISI 316L tratado por feixe de elétrons e recoberto por SrHAp. Ensaios eletroquímicos de EIE e OCP, em solução de Ringer a $37^{\circ} \mathrm{C}$, mostraram este ser um método promissor para a melhora da resistência à corrosão localizada. As amostras submetidas ao método apresentaram maiores resistências de polarização quando comparadas com as sem recobrimento.

KOLCHAKOV et al. (2005) estudaram os filmes passivos formados sobre aços inoxidáveis ferríticos em soluções de $\mathrm{NaOH}$, em altas temperaturas. Usaram EIE para identificar os "limites" detectáveis por meios eletroquímicos e tentar desenvolver um modelo para o mecanismo de condução do óxido formado no estado passivo. A composição superficial do filme passivo foi estimada por XPS e AES. Verificaram que o óxido formado na liga Fe-18\%Cr em sal (hidróxido) fundido tem caráter duplex, sendo que a parte mais interna cresce pela difusãomigração, em estado sólido, de defeitos pontuais, e a parte mais externa, por um mecanismo de dissolução-precipitação.

ABREU et al.(2006) estudaram a condutividade de filmes formados ao ar sobre ligas $\mathrm{Fe}-\mathrm{Cr}-\mathrm{Ni}$, usando a técnica de espectroscopia de impedância eletroquímica (EIE). Os materiais avaliados foram os aços AISI 430, AISI 304L, AISI 316 e uma liga à base de Ni. Observaram que o aumento no teor de $\mathrm{Ni}$ diminui a condutividade e produz filmes mais finos. Para o aço AISI 430, o diagrama de Nyquist obtido correspondeu a um comportamento puramente capacitivo, imediatamente após a imersão. Para os outros materiais avaliados, a resistência associada a estes decresce com o tempo de imersão e os arcos são mais capacitivos quanto maior o teor de $\mathrm{Ni}$.

BAUTISTA et al. (2008) avaliaram dois tipos de aços inoxidáveis ferríticos sinterizados: AISI 409L Nb e AISI 434L. A partir dos resultados de espectroscopia de impedância eletroquímica (EIE), eles propuseram um novo parâmetro chamado "FAA": fator de área ativa. Este fator quantifica aproximadamente a relação entre as superfícies aparente e real expostas à corrosão. As medidas de EIE foram realizadas 20 min após a estabilização do potencial de corrosão ( $E_{\text {corr }}$ ), a faixa de frequências analisada foi de $10^{5}$ a $6 \times 10^{-3}$ $\mathrm{Hz}$. Os diagramas de Bode (ângulo de fase) para o aço AISI 409L Nb sinterizado em três diferentes temperaturas apresentaram duas constantes de tempo 
sobrepostas, com pico de ângulo de fase ao redor de $-50^{\circ}$. Para o aço AISI 434L, o mesmo comportamento foi observado. Após exposição à alta temperatura, foi observada a formação de escamas na superfície do aço AISI 434L, gerando uma terceira constante de tempo na região de mais baixas frequências no espectro de impedância. A partir do modelo proposto para os aços sinterizados, os autores concluem que um aumento na densidade do material leva a uma redução na resistência à corrosão por unidade de área ativa, o que é diretamente proporcional ao aumento da temperatura de sinterização.

O aço inoxidável austenítico AISI 316L é um dos mais utilizados para aplicações em implantes e próteses. Em estudo recente, MEHDIPOUR et al. (2012) investigaram a deposição eletroforética de partículas de biovidro sobre este aço inoxidável. O comportamento eletroquimico foi avaliado por meio de ensaios de polarização e EIE, a temperatura ambiente e em solução de saliva artificial, para amostras com e sem deposição de biovidro. As amostras que receberam deposição de biovidro tornaram-se mais passivas, ou seja, apresentaram valores de densidade de corrente de corrosão inferiores às sem tratamento. Os diagramas de Bode (ângulo de fase) mostraram duas constantes de tempo atribuídas à presença do biovidro. Os diagramas de Nyquist indicaram que as amostras tratadas têm maior resistência total do que as outras. Os diagramas de EIE foram ajustados com um CEE igual ao da Figura 5D. Concluiram que o recobrimento atua como uma barreira contra os íons corrosivos, aumentando assim, a resistência à corrosão deste biomaterial.

RONDELLI et al. (2005) avaliaram um aço inoxidável austenítico isento de níquel para aplicações ortopédicas, por meio de ensaios de EIE. Os ensaios foram realizados em células eletroquímicas utilizando quatro meios diferentes: solução salina tamponada de fosfato (PBS); meio mínimo essencial (MEM); MEM $+10 \%$ soro bovino fetal (FCS); MEM + $10 \%$ soro bovino fetal + linhagem de células fibroblásticas L929 (Cell). Os diagramas de Bode apresentaram dois máximos e os melhores ajustes foram obtidos pelo circuito elétrico equivalente com duas combinações R-CPE em paralelo (Figura 5D). Os diagramas de Nyquist, após uma semana de imersão nas soluções citadas, revelaram menores impedâncias associadas ao aço isento de Ni em PBS. Os autores chamam a atenção para o fato de que diferenças nas propriedades protetoras, formadas em vários meios, se devem às diferenças em composição das camadas externas. $\mathrm{A}$ 
resistência do filme interno aumenta em função do tempo de imersão e diminuiu na seguinte sequência, segundo o meio de ensaio: $M E M>C$ ell $>F C S>P B S$.

\subsubsection{Propriedades eletrônicas do filme passivo - Técnica de Mott-Schottky}

Os filmes passivos, formados sobre os aços inoxidáveis, possuem propriedades eletrônicas de um óxido duplex, constituído por uma camada externa de óxidos e hidróxidos, ricos em ferro, e uma camada interna, rica em óxido de cromo. A camada externa apresenta comportamento de um semicondutor extrínseco tipo-n e a interna do tipo-p (HAKIKI et al., 1995, HAKIKI e DA CUNHA BELO, 1998, MARTINI e MULLER, 2000, MONTEMOR et al., 2000, ANTUNES, 2006, TERADA, 2008).

A resposta de um filme óxido, como um semicondutor, pode ser expressa pelo gráfico do inverso da capacitância ao quadrado $\left(1 / \mathrm{C}^{2}\right)$ versus potencial (E), também conhecido como gráfico de Mott-Schottky (Figura 6).

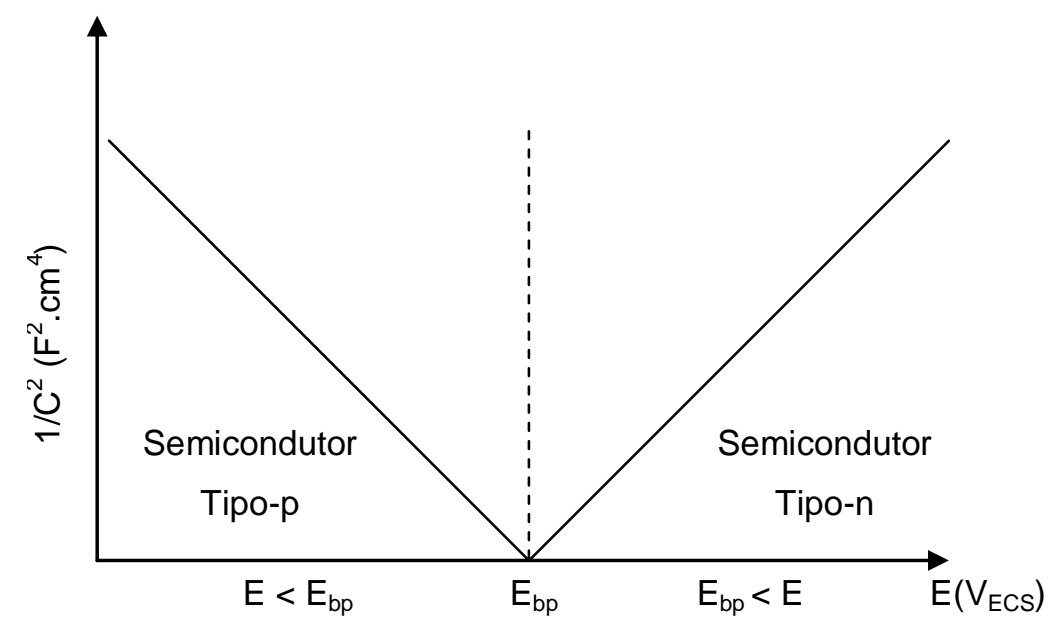

Figura 6 - Gráfico esquemático da resposta de capacitância de um óxido duplex em função do potencial, obtidos pelo método de Mott-Schottky.

O gráfico da Figura 6 é obtido através de medidas de impedância, em uma frequência predefinida, para a determinação dos valores de capacitância. Os semicondutores tipo-n ou tipo-p geram retas com inclinações distintas, o que permite a sua identificação. Num óxido duplex, o ponto de intersecção das duas retas com o eixo $X$ é denominado potencial de banda plana $\left(E_{b p}\right)$. No $E_{b p}$ não há transferência de cargas no interior do semicondutor. (HAKIKI et al., 1995, GE et al., 2003, SHAHRYARI e OMANOVIC, 2007). Em potenciais acima ou abaixo do $E_{b p}$ os semicondutores podem ficar em estado de acumulação ou depleção. No estado de acumulação o semicondutor gera um contato ôhmico, logo a passagem de cargas ocorre praticamente sem resistência. No estado de depleção tem-se 
um contato retificador, no qual a resistência à passagem de corrente elétrica depende da polaridade da tensão aplicada. A resposta de capacitância do diagrama de Mott-Schottky é dada pelo semicondutor quando em estado de depleção.

Em potenciais acima do $E_{b p}$, os óxidos presentes no filme passivo e que respondem como um semicondutor extrínseco tipo-p, estão em condição de acumulação. Neste mesmo potencial ocorre a depleção dos óxidos que respondem como semicondutor extrínseco tipo-n. Portanto, o gráfico de MottSchottky descreverá o comportamento de um semicondutor extrínseco tipo-n. Em potenciais inferiores ao $E_{b p}$ a situação se inverte e tem-se a resposta de capacitância para um semicondutor extrínseco tipo-p (ANTUNES, 2006).

Um semicondutor extrínseco tipo-p é caracterizado pelo excesso de cargas positivas, geradas por lacunas ou buracos eletrônicos e, portanto, são chamados de aceitadores de cargas. O semicondutor extrínseco tipo-n apresenta excesso de cargas negativas, causado por lacunas de íons metálicos, sendo denominado doador de carga. São considerados dopantes tanto os aceitadores, quanto os doadores de cargas (ANTUNES, 2006). Segundo MONTEMOR et al. (2000) e ANTUNES (2006), a concentração de dopantes no filme passivo é inversamente proporcional à resistência à corrosão dos aços inoxidáveis. A densidade de dopantes pode ser calculada pela equação de Mott-Schottky (Equação 2).

$$
\frac{1}{\mathrm{C}^{2}}=\frac{2}{\varepsilon \varepsilon_{0} \mathrm{eN}_{\mathrm{q}}}\left(-\mathrm{E}+\mathrm{E}_{\mathrm{bp}}+\frac{\mathrm{kT}}{\mathrm{e}}\right)
$$

Equação 2

$\mathrm{Na}$ Equação 2, C representa a capacitância da interface do filme passivo com o eletrólito, $\boldsymbol{\varepsilon}$ é a constante dielétrica do filme passivo, $\boldsymbol{\varepsilon}_{0}$ o valor da permissividade do vácuo, $\boldsymbol{e}$ a carga elementar, $\mathbf{N}_{\mathbf{q}}$ a concentração de dopantes, $\mathbf{E}$ o potencial aplicado, $\mathbf{k}$ a constante de Boltzmann, $\mathbf{T}$ a temperatura em graus Kelvin e $\mathbf{E}_{\mathrm{bp}}$ o potencial de banda plana (MONTEMOR et al., 2000, GE et al., 2003, ANTUNES, 2006, SHAHRYARI e OMANOVIC, 2007).

DI PAOLA (1989) publicou um estudo sobre as propriedades semicondutoras do filme passivo de três aços inoxidáveis, sendo eles um aço inoxidável ferrítico experimental de extra baixo intersticiais, um aço superaustenítico e um aço austenítico comercial (AISI 304). Foi utilizada a técnica 
de Mott-Schottky em diferentes frequências e soluções. Os resultados indicaram que os filmes passivos apresentam comportamento de um semicondutor tipo-n altamente dopado $\left(10^{20}-10^{21}\right.$ dopantes. $\mathrm{cm}^{-3}$ a $\left.1 \mathrm{kHz}\right)$. As medidas, em diferentes valores de frequência, mostraram que houve dispersão dos resultados de capacitância. Esse comportamento pode ser atribuído a diversas causas como, por exemplo, a distribuição não uniforme de doadores no filme passivo ou a natureza amorfa do mesmo. O potencial de banda plana mostrou ter uma dependência linear com o $\mathrm{pH}$.

SCHMUKI e BÖHNI (1992) estudaram as propriedades eletrônicas do filme superficial de três aços inoxidáveis austeníticos. Todos os materiais apresentaram um filme passivo com comportamento de um semicondutor tipo-n e com estrutura eletrônica altamente defeituosa. $O$ aço que apresentou a melhor resistência à corrosão localizada por pite foi o que possuía a menor densidade de dopantes no filme passivo. Com base na densidade de defeitos da banda semicondutora do filme de óxido, concluíram que existe uma relação inversa entre a densidade de dopantes e a estabilidade do filme passivo.

HAKIKI et al. (1995) estudaram o comportamento dos filmes passivos formados sobre o aço inoxidável 304 e diferentes ligas de $\mathrm{Fe}-\mathrm{Cr}(0 \leq \mathrm{Cr} \leq 30)$, utilizando a técnica de Mott-Schottky. Os resultados obtidos mostraram que o filme óxido responde como um semicondutor tipo-n ou tipo-p, na faixa de potencial acima e abaixo do $E_{b p}$, respectivamente. Este comportamento é consequência das propriedades semicondutoras das regiões do filme passivo que contêm óxido de ferro e óxido de cromo. A interpretação foi suportada por espectroscopia de elétrons Auger (AES), a qual permitiu estabelecer uma relação direta entre a composição química das duas regiões de óxidos e as curvas de Mott-Schottky. Concluíram que o filme passivo, formado sobre o aço 304 e ligas de $\mathrm{Fe}-\mathrm{Cr}$, é composto por duas camadas, uma interna rica em cromo e outra externa rica em ferro. A camada externa de óxidos e hidróxidos de ferro apresenta resposta de um semicondutor extrínseco tipo-n, enquanto a camada interna, de óxido de cromo, o comportamento de um semicondutor tipo-p.

DA CUNHA BELO et al. (1998) estudaram as características semicondutoras de filmes, formados sobre o aço inoxidável AISI 316L, após tratamento de passivação em ácido nítrico a $20 \%$, durante 20 minutos. O eletrólito utilizado foi água do mar artificial. Para as medidas de capacitância, em diferentes períodos, empregou-se a técnica de Mott-Schottky. A composição química 
superficial foi analisada por meio de espectroscopia de fotoelétrons excitados por raios-X (XPS) e por elétrons Auger (AES). No artigo, os autores salientam que a composição dos filmes passivos, formados sobre os aços inoxidáveis, depende do meio ao qual estão expostos. Em soluções neutras e não agressivas, o filme apresenta duas camadas, uma interna, rica em óxidos de cromo, e outra externa, essencialmente formada por óxidos de ferro. Após passivação em ácido nítrico, a camada interna permanece composta, principalmente, por óxidos de cromo. Porém, na camada externa, tem-se uma mistura de óxidos de cromo e ferro, além de uma pequena concentração de níquel. Durante a imersão em água do mar artificial, o filme passivo formado sobre o aço inoxidável AISI 316L tornou-se mais rico em hidróxidos de cromo. Esta evolução na composição química do filme foi consistente com o aumento no potencial de corrosão, que também pôde ser explicado pela redução do número de dopantes, mensurados pela técnica de Mott-Schottky.

TAVEIRA et al. (2010) estudaram o efeito da incorporação de Mo e Nb nas propriedades eletrônicas do filme de óxido formado sobre o aço AISI 304L, utilizando a abordagem de Mott-Schottky. As amostras foram polarizadas, anodicamente, em potenciais de $+750 \mathrm{mV}_{\mathrm{NHE}} \mathrm{e}+1000 \mathrm{mV}_{\mathrm{NHE}}$, durante $1 \mathrm{~h}$ a $95{ }^{\circ} \mathrm{C}$, em soluções de $0,25 \mathrm{~mol} \mathrm{~L}^{-1} \mathrm{Na}_{2} \mathrm{MoO}_{4}(\mathrm{pH} \mathrm{1,8})$, de $0,25 \mathrm{~mol} \mathrm{~L}^{-1} \mathrm{NH}_{4} \mathrm{H}_{2} \mathrm{NbO}\left(\mathrm{C}_{2} \mathrm{O}_{4}\right)$ $3 \mathrm{H}_{2} \mathrm{O}\left(\mathrm{pH}\right.$ 1,1) e de $\mathrm{H}_{2} \mathrm{SO}_{4}(\mathrm{pH}$ 1,8). O filme formado foi analisado por espectroscopia de elétrons Auger (AES) e espectroscopia fotoelétrica por raios- $X$ (XPS). Observaram que a anodização promoveu o enriquecimento de cromo na camada interna tipo-p. Na camada externa tipo-n houve maior concentração de ferro e incorporação do oxalato de $\mathrm{Nb}$ ou Mo. Mesmo afirmando que a passivação melhorava as propriedades protetoras da camada passiva, verificaram que as densidades de dopantes dos filmes aumentaram em todos os tratamentos. Supõem que este resultado contraditório pode ter sido influenciado pela alteração na área ativa superficial. A melhora na resistência à corrosão por pite dos aços passivados é, possivelmente, devido ao aumento de espessura do filme e às alterações em sua composição.

A passividade do aço inoxidável AISI 316L, em solução de borato, foi investigada por FENG et al. (2010), utilizando a técnica de Mott-Schottky, espectrometria de absorção atômica (AAS) e XPS. Os resultaram indicaram que na curva de polarização, dentro da região passiva, há potenciais onde ocorrem mudanças de inclinação ( $\left.0 \bigvee_{S C E}, 0,2 \bigvee_{S C E}, 0,4 \bigvee_{S C E}, 0,6 \bigvee_{S C E}, 0,85 \bigvee_{S C E}\right)$. O filme 
passivo, formado nestes potenciais, apresentou propriedades eletroquímicas e semicondutoras diferentes. Os resultados de AAS indicaram que houve um processo de dissolução e formação do filme passivo. Entre $0 \mathrm{~V}_{\mathrm{SCE}}$ e $0,2 \mathrm{~V}_{\mathrm{SCE}}$, $\mathrm{O}$ filme consiste principalmente por óxido de ferro, $\operatorname{Cr}(\mathrm{OH})_{3}$ e um pouco de $\mathrm{Fe}_{2}\left(\mathrm{MoO}_{4}\right)_{3}$. Na faixa de $0,2 \mathrm{~V}_{\mathrm{SCE}}$ e $0,4 \mathrm{~V}_{\mathrm{SCE}}$, a camada passiva é uma mistura de óxido de ferro, $\mathrm{NiO}$ e $\mathrm{Cr}_{2} \mathrm{O}_{3}$. Para potenciais, entre $0,4 \mathrm{~V}_{\text {SCE }}$ e $0,6 \mathrm{~V}_{\text {SCE }}$, tem-se a formação de $\mathrm{Cr}_{2} \mathrm{O}_{3}$. Concluiram que as mudanças de inclinações, observadas nas curvas de polarização, estão relacionadas às alterações na composição do filme.

OGUZIE et al. (2010) estudaram o efeito da adição de cobre em aços inoxidáveis ferríticos, austeníticos e martensíticos, em solução de $0,1 \mathrm{M}$ de $\mathrm{H}_{2} \mathrm{SO}_{4}$, por meio de polarizações potenciodinâmicas, EIE e Mott-Schottky. As propriedades semicondutoras do óxido, estudadas pela técnica de Mott-Schottky, indicaram a existência de um filme passivo de estrutura duplex, composto por duas camadas de óxidos com semicondutividades distintas (tipo-p e tipo-n), tanto para as amostras com e sem $\mathrm{Cu}$. A presença de íons $\mathrm{Cu}^{2+}$, no filme passivo, aumentou a densidade de doadores $(\mathrm{Nd})$ e de aceitadores $(\mathrm{Na})$ de cargas, possivelmente, afetando a estabilidade do mesmo. Os ensaios de polarização e EIE revelaram que a adição de cobre melhorou a resistência à corrosão para todos os aços ensaiados, através da supressão da dissolução ativa do filme superficial.

\subsection{Corrosão em frestas}

O corpo humano é um meio biológico agressivo, contendo cloretos que podem, por si só, acelerar a dissolução de ligas metálicas liberando íons metálicos potencialmente tóxicos (JACOBS et al, 1998). A variação de composição e/ou concentração, entre eletrólitos dentro de um sistema, pode ocasionar corrosão eletroquímica por célula de concentração. Como exemplo, a presença de placa bacteriana, na região interproximal dos dentes, promove a formação de um eletrólito diferente do produzido pela saliva na superfície oclusal. Caso tenha uma restauração metálica sob os resíduos alimentares, poderá ocorrer uma corrosão eletroquímica acelerada. Riscos, trincas e falhas marginais são exemplos de irregularidades, que podem criar micropilhas de aeração diferencial entre regiões de uma mesma restauração ou prótese, causando uma corrosão por diferença de concentração. 
O mecanismo de corrosão em frestas é similar ao de corrosão por pite, porém, a condição de fresta ocorre em um ambiente ocluso pré-existente, enquanto que o pite se forma sobre uma superfície livre. Inicialmente, a fresta e a região externa estão passivas. Em condições favoráveis, ocorre uma queda na concentração de oxigênio no interior da fresta e a curva catódica do oxigênio cruza o trecho ativo (se houver), levando à corrosão do metal (reação anódica $\left.\mathrm{Me} \rightarrow \mathrm{Me}^{+z}+n e^{-}\right)$. A presença de íons $\mathrm{Me}^{+z}$ atrai os íons $\mathrm{Cl}^{-}$para a região interna, formado um sal $\mathrm{Me}^{+z} \mathrm{Cl}^{-}$. O sal reage com a água, formando um hidróxido metálico $(\mathrm{MeOH})$ e ácido clorídrico $\left(\mathrm{H}^{+} \mathrm{Cl}\right)$. Os elétrons da reação anódica reagem com o oxigênio e a água, formando íons hidroxila $\left(\mathrm{O}_{2}+2 \mathrm{H}_{2} \mathrm{O}+4 \mathrm{e}^{-} \rightarrow 4 \mathrm{OH}^{-}\right)$. A diferença de cargas, entre a região interna (anódica) e a externa (catódica), gera um par galvânico que acelera o processo de corrosão, também agravado pela diminuição local do $\mathrm{pH}$.

As técnicas eletroquímicas aplicadas no estudo da corrosão em frestas podem, em princípio, serem as mesmas utilizadas para o estudo da corrosão por pite, desde que se tenha algum dispositivo em contato com a amostra formando uma região oclusa (KERNS, 1995).

STREICHER (1974) e BRIGHAM (1974) publicaram artigos sugerindo uma padronização para o teste de corrosão em fresta. Para a obtenção da região de fresta, STREICHER (1974) utilizou dois blocos poliméricos presos por elásticos, posicionados em lados opostos de uma amostra. Esta proposição, assim como a atual norma ASTM G48, apresentou várias desvantagens como: a possibilidade de quebra do elástico; falta de uniformidade na compressão da amostra; o polimento final da superfície do bloco de polímero não foi especificado; a relação entre a área de fresta e a área livre não pôde ser medida com precisão; muitas vezes a corrosão teve inicio nas bordas em contato com os elásticos, ao invés de sob os blocos de polímero (CORBETT, 1992).

Em substituição aos elásticos, diversos autores têm proposto novos sistemas, nos quais a pressão na amostra é aplicada por meio de um parafuso de torque. Porém, não há um concenso sobre qual valor utilizar, tendo sido reportado na literatura torques de 0,28 N-m até 8,5 N-m (DAVIS e STREICHER-1985, HIBNER-1986, NAGASWAMI e STREICHER-1983, TRESEDER-1980, CORBETT-1991).

As limitações no uso do torque, como meio de controlar o aperto da fresta, foram discutidas por OLDFIELD (1989). Ele concluiu que o torque não 
pode ser relacionado com a força entre a amostra e a fresta formada. Além disso, o torque pode relaxar com o tempo, resultando em uma variação de força durante o teste.

Outra preocupação em criar frestas artificiais é a sua configuração geométrica (largura e profundidade da endentação, altura, diâmetro). Novamente, assim como no uso de aperto por torque, não há um padrão e a geometria varia de laboratório para laboratório e até durante um mesmo experimento (BRIGHAM, 1981).

Conforme exposto anteriormente, as normas possuem suas limitações, principalmente quando a intenção é avaliar biomateriais. Normas atuais (ASTM F746-04 e ABNT NBR 15613-4) surgiram como meio de padronizar o estudo da corrosão, por pite ou fresta, em implantes cirúrgicos metálicos. O princípio do método de ensaio da ABNT NBR 15613-4 é descrito a seguir: um corpo de prova cilíndrico, com flange cônico inerte encaixado, é imerso em um meio salino de fosfato tamponado, a $37^{\circ} \mathrm{C}$, por $1 \mathrm{~h}$, para estabelecer o potencial de corrosão. A seguir, a amostra é polarizada potenciostaticamente no sentido anódico, até um valor muito mais elevado que o potencial de corrosão, sendo depois reduzido o mais rápido possível. As informações de corrente e potencial são monitoradas e servem para indicar se houve algum ataque. Após o ensaio, a amostra deve ser observada por microscopia para saber se ocorreu ataque na fresta com o flange (fresta), na área livre (pite) ou em ambos. Para a execução desta norma, é necessária a confecção de um corpo de prova e um flange nas medidas exatas da Figura 7A e B, que, posteriormente, serão acopladas em uma haste do eletrodo, como descrito na ASTM G5 (Figura 7C).
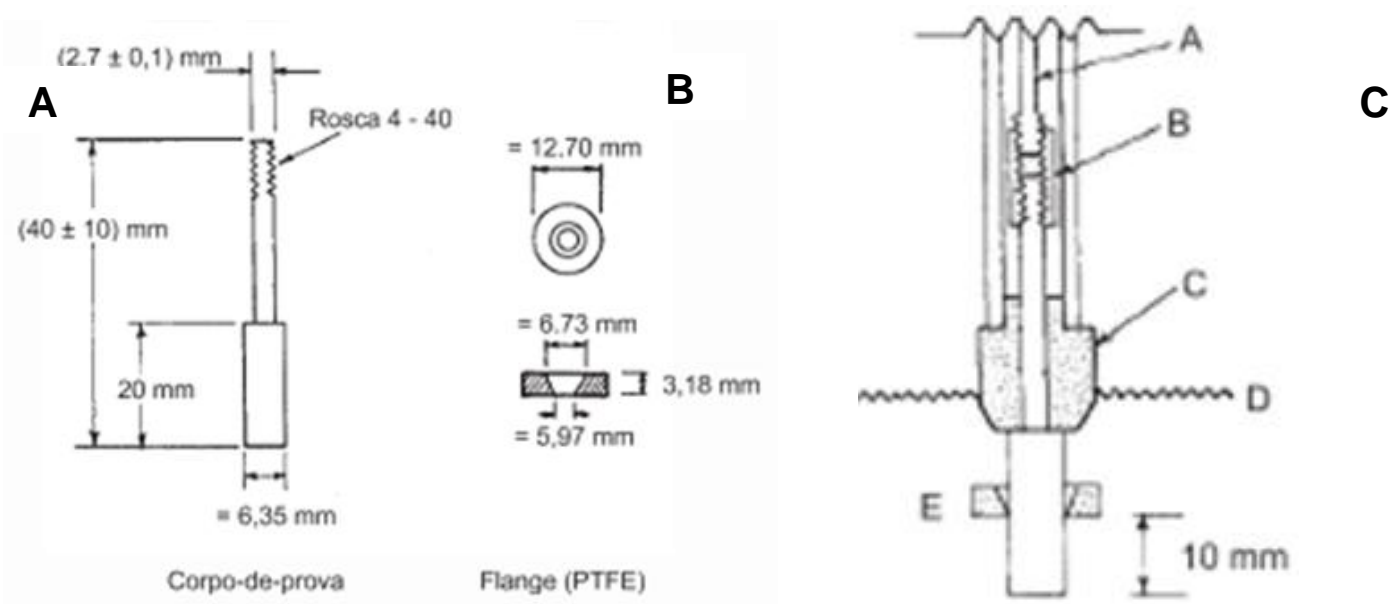

Figura 7 - Padrões para preparação do ensaio de corrosão segundo a norma ABNT NBR 15613-4. A) Corpo de prova; B) Flange; C) Corpo de prova acoplado a haste ASTM G5. 
CHENG et al. (2006) estudaram a resistência à corrosão em fresta do $\mathrm{NiTi}$ em solução de Hanks a $37^{\circ} \mathrm{C}$. Foram empregadas técnicas eletroquímicas segundo a norma ASTM F746-04. Os materiais selecionados para este estudo foram NiTiCu, Ti comercialmente puro (cp Ti), Ti6Al4V e o aço inoxidável 316L. Segundo a norma, a suscetibilidade à corrosão em frestas é caracterizada pelo maior potencial no qual as amostras ainda não apresentam aumento na densidade de corrente, após a estimulação potenciostática anódica. Posteriormente ao ensaio, as amostras foram observadas por $\mathrm{MO}$, como visto na Figura 8.

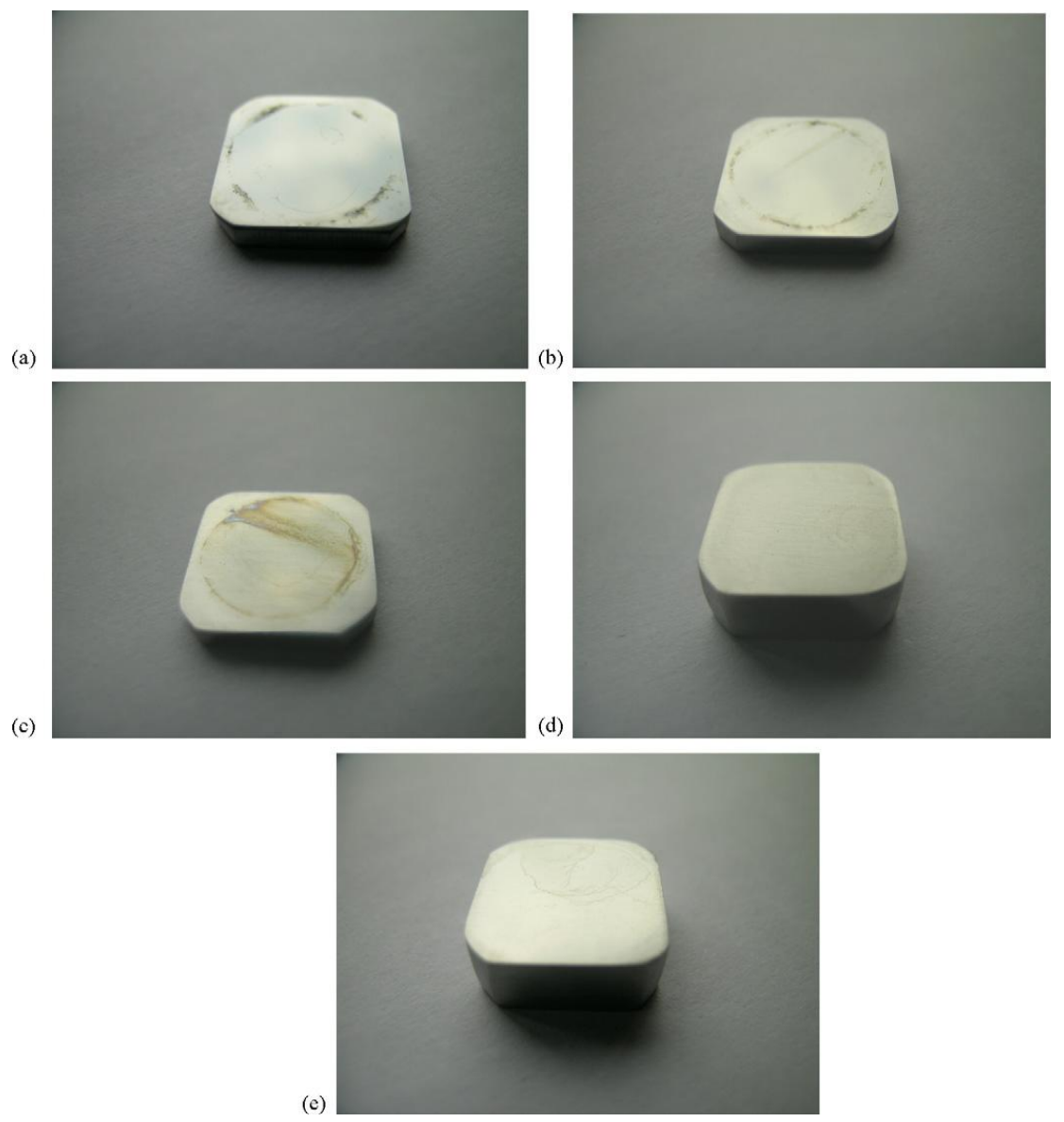

Figura 8 - Imagens obtidas por MO das superfícies de fresta após o teste de estimulação/repassivação. (a) NiTi; (b) NiTiCu; (c) 316L; (d) Ti cp; (e) Ti6Al4V (CHENG et al., 2006).

Com base nos resultados de estimulação/repassivação, a suscetibilidade à corrosão em fresta das diferentes amostras, em solução de Hanks a $37{ }^{\circ} \mathrm{C}$, foi: Ti $\approx$ Ti6Al4V « $316 \mathrm{~L}<\mathrm{NiTiCu}<\mathrm{NiTi}$. O efeito benéfico do $\mathrm{Cu}$ pode ser atribuído à redeposição de $\mathrm{Cu}$ dentro da fresta, como evidenciado por 
EDS. Uma vez iniciado o processo de corrosão em fresta, as densidades de corrente não diferiram muito entre si.

DAYAL et al. (1983) propuseram um novo arranjo experimental (Figura 9). Foi observada a existência de um potencial crítico de fresta, análogo ao potencial crítico de pite. O potencial crítico de fresta foi independente da taxa de varredura para velocidades de 5 a $100 \mathrm{mV} \cdot \mathrm{min}^{-1}$. A resistência à corrosão em fresta de três aços inoxidáveis austeníticos foi avaliada em meio de 0,5 mol. $\mathrm{L}^{-1}$ $\mathrm{NaCl}$. Os resultados indicaram que a resistência do aço $316>304>310$.

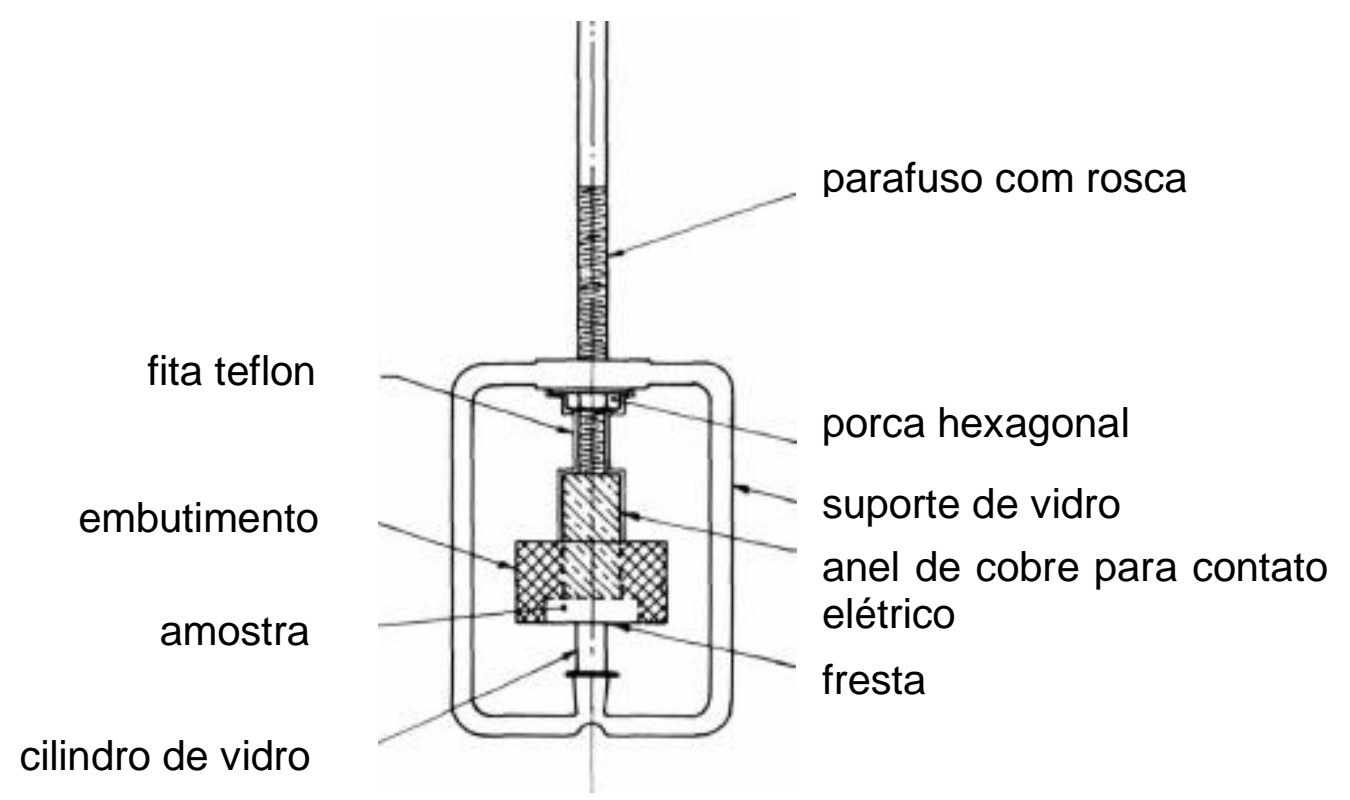

Figura 9 - Arranjo experimental proposto por DAYAL et al. (1983) para estudo da corrosão em fresta.

BOMBARA E CAVALLINI (1977) investigaram as possíveis causas de falhas de parafusos de fixação, feitos em aço AISI 316L, utilizados na estabilização de fraturas ósseas femurais. Os autores evidenciaram a existência de frestas nos parafusos implantados, as quais promoveram o aparececimento de sítios de aeração diferencial, com acúmulo progressivo de íons $\mathrm{Cl}^{-}$nas regiões anódicas e redução do potencial de pite. Observaram que a corrosão sob tensão levou à falha dos componentes, tendo seu início ocorrido nos pites formados nas regiões de fresta. $O$ alto teor de inclusões de enxofre no aço $316 \mathrm{~L}$ foi o possível responsável por sua suscetibilidade à corrosão por pite. Sugeriram um novo aço ferrítico, de alto cromo e baixo teor de intersticiais, como um substituto ao $316 \mathrm{~L}$.

MUDALI e DAYAL (2000) estudaram a corrosão em frestas através de curvas de polarização potenciodinâmicas anódicas. Foram avaliados aços inoxidáveis austeníticos com adição de nitrogênio e o arranjo experimental foi o 
mesmo proposto por DAYAL et al. em 1983 (Figura 9). Por meio das curvas de polarização e imagens de MO (Figura 10), concluíram que a influência combinada do nitrogênio e molibdênio é significante no aumento da resistência à corrosão em fresta.

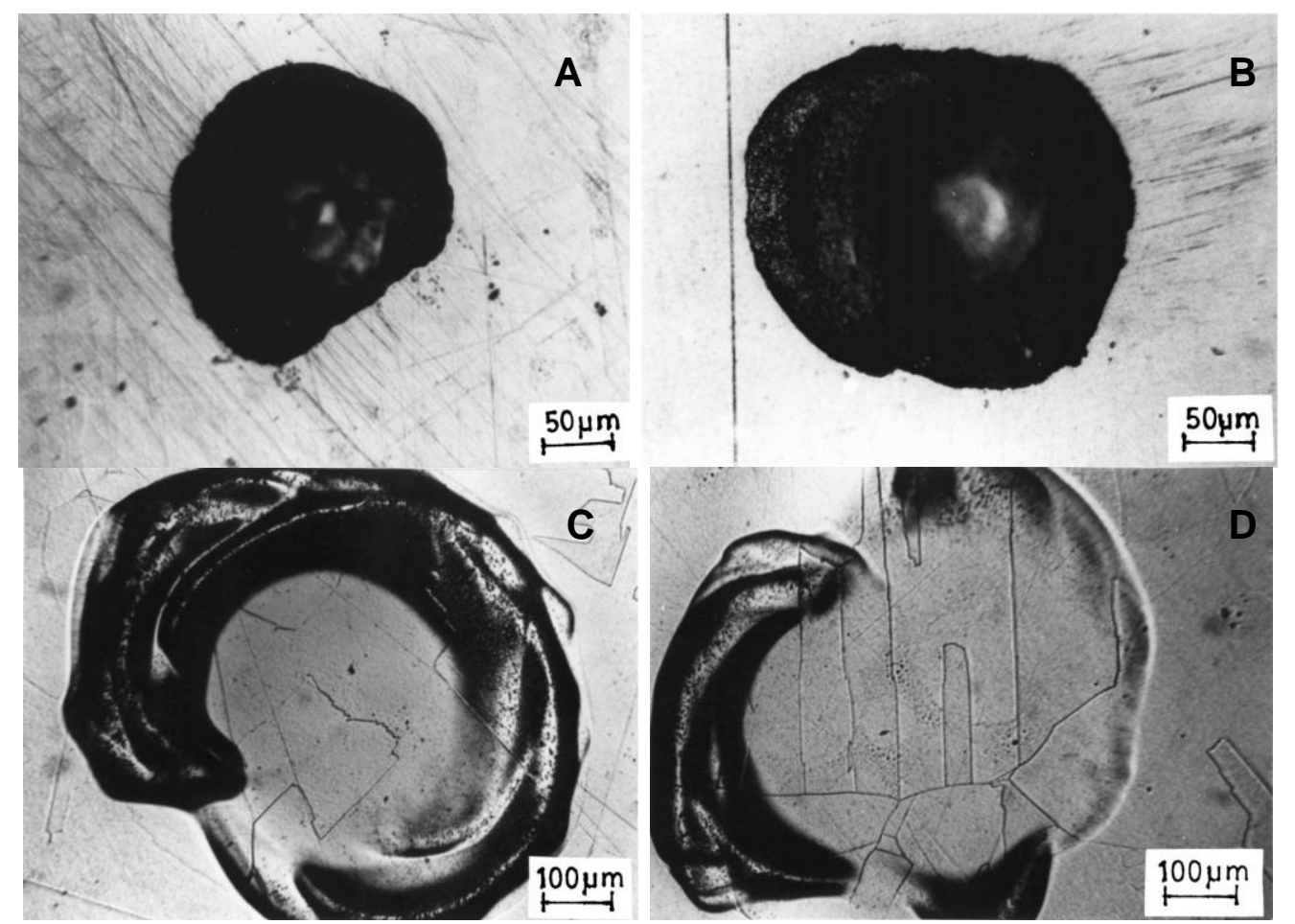

Figura 10 - Micrografias óticas após ataque em fresta dos aços: A) 304 (0,086\% N), B) $316(0,16 \%$ N), C) $317(0,088 \%$ N) e D) 317 SS $(0,14 \%$ N). MUDALI e DAYAL (2000)

RECLARU et al. (2014) publicaram um artigo sobre a importância do estudo da corrosão em situações agressivas, como em ensaios na condição de fresta associados ou não à fadiga. A resistência à corrosão, entre a parte distal e proximal de próteses de quadril modulares, foi avaliada por método eletroquímico (segundo a norma ASTM F746), em combinação com um teste cíclico de fadiga. A fresta é inerente a junção entre as partes do implante (Figura 11). Ambas as próteses testadas, uma de Ti6Al4V e a outra de Ti6Al7Nb, não apresentaram tendência à corrosão na presença apenas da condição de fresta. Quando submetidas ao clico de fadiga e polarização, os implantes apresentaram trincas no módulo distal e corrosão generalizada na interface entre as duas partes. 


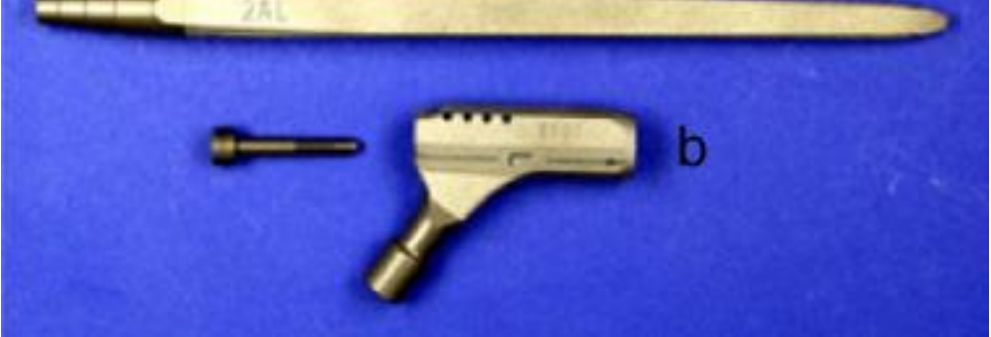

Figura 11 - Prótese ortopédica de fêmur. A parte proximal (b) encaixa-se na distal (a), formando uma região de fresta (c). (RECLARU et al., 2014).

RONDELLI e VICENTINI (1998) estudaram a resistência à corrosão de diferentes fios ortodônticos de $\mathrm{NiTi}$, por meio de técnicas eletroquímicas. Como material de referência, empregaram fios de aço inoxidável e uma liga à base de cobalto (Co-19Cr23Ni3,5Mo - \% em massa). A corrosão localizada foi avaliada com uma modificação da norma ASTM F746, proposta pelos autores (Figura 12), a fim de possibilitar o estudo de amostras na forma de fio. A condição de fresta foi obtida por meio de dois discos de resina presos ao fio ortodôntico por dois parafusos. Os testes potenciodinâmicos, em saliva artificial a $40{ }^{\circ} \mathrm{C}$, indicaram resistência à corrosão por pite dos fios de $\mathrm{NiTi}$, similar a dos fios de liga de cobalto. Por outro lado, o fio de aço inoxidável obteve um potencial de pite abaixo dos demais. Os resultados de corrosão por fresta indicaram que o aço inoxidável e a liga de NiTi apresentam alta suscetibilidade a este tipo de ataque.

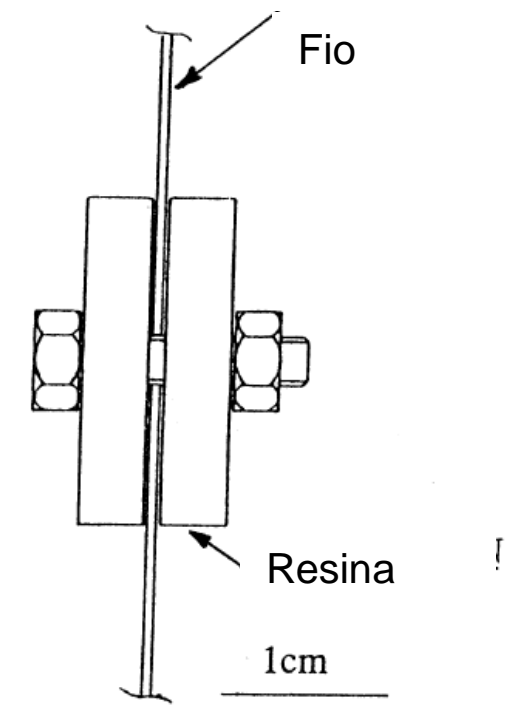

Figura 12 - Vista esquemática lateral do eletrodo usado para modificar o teste ASTM F746. Fonte: RONDELLI e VICENTINI (1998) 


\section{MATERIAIS E MÉTODOS}

\subsection{Materiais}

Para este estudo foi selecionado o aço inoxidável ferrítico AISI 444 (Arcelor Mittal Inox, Brasil). A resistência à corrosão deste material foi avaliada utilizando-se técnicas eletroquímicas. Os resultados foram comparados com os do aço inoxidável austenítico ISO 5832-1 (Baumer S/A, Brasil) e com o ferrítico utilizado para a confecção do componente Neo Magnet (Attachments International Inc., Califórnia, EUA). Para o aço inoxidável AISI 444 foi proposto um tratamento de solubilização a $1050 \stackrel{\circ}{ } \mathrm{C}$, por 30 minutos, seguido de resfriamento por imersão em água. Foram adotadas as abreviações 444 para a liga AISI 444 como recebida, 444S para a liga solubilizada, ISO para o aço ISO 5832-1 e NeoM para o componente de próteses odontológicas Neo Magnet.

\subsubsection{Aço inoxidável austenítico ISO 5832-1}

O aço ISO 5832-1 é comercializado pela Baumer S/A e produzido pela Villares Metals S/A. O material foi fornecido em placas com $18 \mathrm{~mm}$ de largura, 70 $\mathrm{mm}$ de comprimento e $2 \mathrm{~mm}$ de espessura. A composição química nominal é mostrada na Tabela 3.

Tabela 3 - Composição química nominal (\% em massa) do aço ISO 5832-1

\begin{tabular}{|c|c|c|c|c|c|c|c|c|c|c|}
\hline$\overline{\mathrm{Cr}}$ & $\mathbf{N i}$ & Mo & $\mathrm{Mn}$ & $\overline{\mathrm{Si}}$ & $\overline{\mathrm{Cu}}$ & $\bar{P}$ & $\mathbf{N}$ & $\mathbf{S}$ & $\bar{C}$ & $\mathrm{Fe}$ \\
\hline $\begin{array}{c}17,0- \\
19,0\end{array}$ & $\begin{array}{r}13,0- \\
15,0\end{array}$ & $\begin{array}{c}2,25- \\
3,0\end{array}$ & $\leq 2,0$ & $\leq 1,0$ & $\leq 0,50$ & $\leq 0,025$ & $\leq 0,10$ & $\leq 0,010$ & $\leq 0,030$ & bal. \\
\hline
\end{tabular}

A caracterização microestrutural desta liga mostrou que esta apresenta estrutura austenítica. A presença de estrutura cristalina exclusivamente austenítica torna o aço não ferromagnético, impossibilitando sua utilização para conectores protéticos magnéticos com aplicação odontológica. Devido à sua composição química e homogeneidade estrutural, este material apresenta alta resistência à corrosão em meios fisiológicos e, por isso, foi adotado como material de referência nos ensaios eletroquímicos.

\subsubsection{Aço inoxidável ferrítico AISI 444}

O aço AISI 444 foi fabricado segundo a norma ASTM A240/A240M 06C e comercializado com o nome ACE P444A. O material foi fornecido em chapa 
com $1 \mathrm{~mm}$ de espessura. Na Tabela 4 é apresentada a composição química nominal do aço AISI 444, mostrando os principais elementos de liga e impurezas.

Tabela 4 - Composição química nominal (\% em massa) do aço AISI 444

\begin{tabular}{cccccccccc}
\hline $\mathbf{C r}$ & $\mathbf{N i}$ & $\mathbf{M o}$ & $\mathbf{M n}$ & $\mathbf{S i}$ & $\mathbf{N b}+\mathbf{T i}$ & $\mathbf{N}$ & $\mathbf{S}$ & $\mathbf{C}$ & $\mathbf{F e}$ \\
\hline $17,5-$ & $\leq 1,00$ & $1,75-$ & $\leq 1,00$ & $\leq 1,00$ & $\leq 0,80$ & $\leq 0,025$ & $\leq 0,030$ & $\leq 0,025$ & bal. \\
19,5 & & 2,50 & & & & & & & \\
\hline
\end{tabular}

Além do aço como recebido, foram preparadas amostras solubilizadas a $1050 \stackrel{\circ}{\circ}$ por 30 minutos (ABREU et al., 2006), com a finalidade de eliminar possíveis precipitados de carbeto de cromo. Uma vez que a história metalúrgica deste aço não é conhecida, a amostra tratada serve como referência para ser comparada ao material como recebido.

\subsubsection{Aço inoxidável ferrítico Neo Magnet}

O sistema de conectores Neo Magnet, desenvolvido pela Attachments International Inc. (EUA), é composto por uma base ferromagnética e um ímã permanente (Figura 13). O ímã fica contido dentro de uma cápsula de aço inoxidável, selada hermeticamente, a qual é fixada dentro da prótese. A base ferromagnética é feita de aço inoxidável ferrítico. Esta deve ser adaptada a uma supraestrutura protética, sobre os implantes ou dentes, e fixada dentro da boca do paciente.

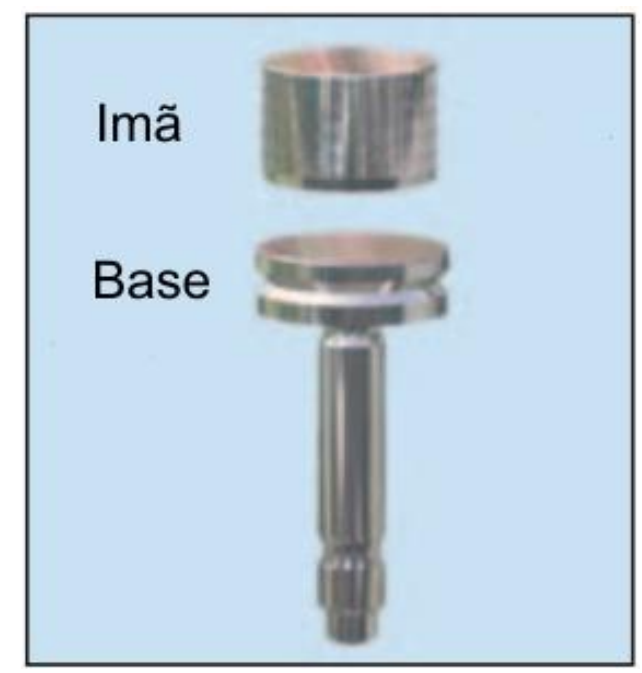

Figura 13 - Sistema de conectores Neo Magnet. Ímã e base ferromagnética.

Com relação aos materiais empregados na fabricação destes componentes, poucas informações foram obtidas do fabricante. Sabe-se que é 
utilizado um ímã permanente de $\mathrm{NdFeB}$, revestido por uma cápsula metálica de proteção e uma base de aço inoxidável ferrítico. Segundo levantamento feito por HOSOI et al. (2008), este aço seria classificado como SUS 444 segundo a norma JIS. A composição química da norma SUS 444 é apresentada na Tabela 5.

Tabela 5 - Composição química nominal (\% em massa) do aço ferrítico NeoM, segundo a norma SUS 444.

\begin{tabular}{ccccccccccc}
\hline & $\mathbf{C r}$ & $\mathbf{N i}$ & $\mathbf{M o}$ & $\mathbf{M n}$ & $\mathbf{S i}$ & $\mathbf{C}$ & $\mathbf{S}$ & $\mathbf{P}$ & $\mathbf{T i}+\mathbf{N b}$ & $\mathbf{F e}$ \\
\hline \multirow{2}{*}{ SUS 444 } & $17,5-$ & $\leq 1,0$ & $1,75-$ & $\leq 1,0$ & $\leq 1,0$ & $\leq 0,025$ & $\leq 0,030$ & $\leq 0,04$ & $\leq 0,8$ & bal. \\
& 19,5 & 2,50 & & & & & & & &
\end{tabular}

A base ferromagnética do sistema Neo Magnet, por já ser utilizada em próteses odontológicas, foi também empregada como material de referência neste trabalho.

\subsection{Métodos}

\subsubsection{Caracterização dos materiais}

A caracterização dos aços foi obtida por microscopia óptica (Leica DM LM - CCTM - IPEN), microscopia eletrônica de varredura (FEI Quanta 650 FEG, LNNano e Philips XL-30 do LabMicro/PMT-USP) e análise química semiquantitativa de microrregiões por dispersão de energia (EDS). A técnica de microanálise por dispersão de energia (EDS) consiste na medida dos raios- $X$ característicos, emitidos de uma região microscópica, após a amostra ser bombardeada por um feixe de elétrons. A interação do feixe eletrônico com a amostra produz diferentes sinais, incluindo-se raios- $X$. As linhas de raios- $X$ característicos são específicas do número atômico. Consequentemente, o seu comprimento de onda ou sua energia podem ser utilizados para identificar o elemento que está emitindo a radiação. No espectro de raios-X por EDS, os fótons emitidos pela amostra atingem um detector de estado sólido de $\mathrm{Si}(\mathrm{Li})$ ou $\mathrm{Ge}$, o qual permite quantificar e obter a sua energia (keV).

Para revelar a microestrutura dos materiais, foram feitos os seguintes ataques metalográficos:

- aço ISO 5832-1 - ataque eletrolítico com ácido oxálico 10\%, 6V por 20s;

- aço AISI 444 - soluçao de Villela a $50{ }^{\circ} \mathrm{C}$ por 30 s e ataque eletrolítico em solução de $\mathrm{NaOH} 30 \%, 6 \mathrm{~V}$ por 30 s;

- aço NeoM - ataque eletrolítico em solução de $\mathrm{NaOH} 30 \%, 6 \mathrm{~V}$ por $20 \mathrm{~s}$. 


\subsubsection{Teste de citotoxicidade in vitro}

O ensaio de citotoxicidade foi efetuado conforme a norma ISO 10.993parte 5 (ISO 10.993, 1992). Este teste avalia a citotoxicidade provocada em células de tecido conectivo de camundongos (NCTC Clone 929 - American Type Culture Collection). As células foram cultivadas em meio mínimo essencial de Eagle (MEM), a $37 \stackrel{\circ}{\circ}$, com adição de $10 \%$ de soro fetal bovino, $0,1 \mathrm{mM}$ de aminoácidos não essenciais e $1 \mathrm{mM}$ de piruvato de sódio (ROGERO et al., 2003).

Amostras do aço inoxidável AISI 444, com área de $5 \mathrm{~cm}^{2}$, foram esterilizadas por autoclavagem a $120^{\circ} \mathrm{C}$, por 20 minutos. Seguiu-se imersão em MEM, durante 10 dias, a $37 \stackrel{\circ}{\circ} \mathrm{C}$, na proporção de $1 \mathrm{~mL} . \mathrm{cm}^{-2}$, obtendo-se um extrato de ensaio com $100 \%$ de concentração. Realizou-se a diluição seriada desta solução para obtenção das concentrações diluídas em 50\%, 25\%, 12,5\% e $6,25 \%$ da inicial. Cada solução foi distribuída em quatro poços de $50 \mu \mathrm{L}$ e adicionado aproximadamente 250.000 células. $\mathrm{mL}^{-1}$ da linhagem NCTC Clone 929 por poço, permanecendo incubado durante $24 \mathrm{~h}$, sob atmosfera úmida com $5 \%$ de $\mathrm{CO}_{2}$. Após este período, foi adicionada uma solução de corante vermelho neutro a $0,1 \%$. O corante, que é um identificador da viabilidade celular, foi incorporado pela população de células e essa incorporação foi diretamente proporcional ao número de células viáveis no meio de cultura. A quantificação do corante foi realizada após $3 \mathrm{~h}$, utilizando um espectrofotômetro leitor de ELISA (marca Tecan - modelo Sunrise) no comprimento de onda de $540 \mathrm{~nm}$. Extratos das amostras, que induzem a toxicidade celular, foram avaliados em várias concentrações. A concentração, que produziu redução de $50 \%$ na absorção do corante, foi adotada como índice de citotoxicidade $\left(\mathrm{IC}_{50 \%}\right)$. Foram utilizadas, como medida de comparação, uma solução de fenol $0,02 \%$ (controle positivo) e uma placa de titânio (controle negativo). O controle negativo foi utilizado para demonstrar a resposta celular no ensaio e o positivo para validar o teste.

\subsubsection{Força de retenção magnética}

Para avaliar a força de atração magnética do aço inoxidável AISI 444, necessária na retenção em um sistema de conexão de prótese, empregou-se um aparato para medição, proposto por MARQUES (2009), conforme esquematizado na Figura 14. 


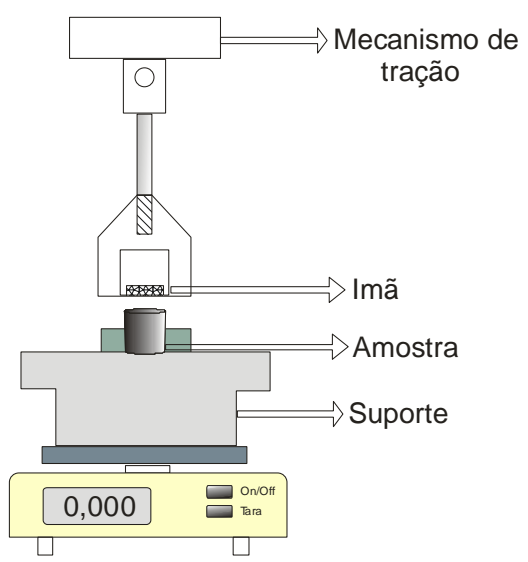

Figura 14 - Desenho esquemático do aparato para medição da força de retenção magnética.

Utilizou-se uma balança digital (Quimis modelo BG 2000), sobre a qual se colocou um suporte para fixação das amostras, sendo aquela em seguida zerada pelo recurso da tecla "tara". Posicionou-se, sobre a balança, um mecanismo para tração contendo um imã de $\mathrm{NdFeB}$, que foi ajustado até se obter contato com a amostra do aço. Desta forma, acionou-se o mecanismo de tração e monitorou-se o decréscimo de massa. Este decréscimo de massa representa o quanto a força de retenção magnética foi capaz de reduzir o peso da amostra mais suporte, antes de ocorrer a separação dos componentes. Foram obtidas 10 leituras por amostra. Os resultados foram normalizados pela área de contato $\left(0,138 \mathrm{~cm}^{2}\right)$ e expressos em $\mathrm{gf} / \mathrm{cm}^{2}$. Como controle utilizou-se um conector ferromagnético comercial (Neo Magnet).

\subsubsection{Ensaios eletroquímicos em condição aerada}

Os ensaios eletroquímicos foram realizados em solução salina tamponada de fosfato (PBS), em $\mathrm{pH} 7$, naturalmente aerada e a $37^{\circ} \mathrm{C}$. A composição química da solução PBS é mostrada na Tabela 6.

Tabela 6 - Composição química (\% em massa) da solução salina tamponada de fosfato (PAN et al., 2000).

\begin{tabular}{ccc}
\hline $\mathrm{NaCl}$ & $\mathrm{Na}_{2} \mathrm{HPO}_{4}$ & $\mathrm{KH}_{2} \mathrm{PO}_{4}$ \\
\hline 0,87 & 0,142 & 0,272 \\
\hline
\end{tabular}

Os eletrodos de trabalho foram preparados com amostras dos materiais estudados. $\mathrm{O}$ aço $\mathrm{NeoM}$, por possuir uma área de trabalho de $4 \mathrm{~mm}$ de diâmetro, foi embutido em resina epóxi de cura a frio (Epofix). As amostras dos aços inoxidáveis AISI 444 e ISO 5832-1 não necessitaram de embutimento. 
Foram posicionadas diretamente na célula eletroquímica, deixando-se uma área de $1 \mathrm{~cm}^{2}$ exposta ao meio, a qual foi delimitada por um o-ring de vedação. $O$ aço ISO 5832-1 foi ensaiado com acabamento superficial, conforme o recebido, equivalente ao utilizado nas próteses ortopédicas. A superfície dos demais eletrodos foi preparada por lixamento, com papel de carbeto de silício até a grana \#2000 e, posteriormente, polida com pasta de diamante até $1 \mu \mathrm{m}$. Em seguida, foi realizada lavagem com acetona e água deionizada, em cuba ultrassônica e, posteriormente, secagem com ar frio. Todos os testes eletroquímicos foram executados em uma célula de corrosão com arranjo de três eletrodos (Figura 15), sendo o eletrodo de referência de $\mathrm{Ag} / \mathrm{AgCl} 3 \mathrm{M}$ e o contra eletrodo um fio de platina. Ao redor da célula eletroquímica, enrolou-se uma resistência para aquecimento, a qual foi conectada a um controlador de temperatura digital microprocessado (Figura 16). Empregou-se um termopar modelo PT100, com precisão de $0,1^{\circ} \mathrm{C}$, o que permitiu manter a temperatura dentro da variação de $\pm 0,5^{\circ} \mathrm{C}$, após o equilíbrio.

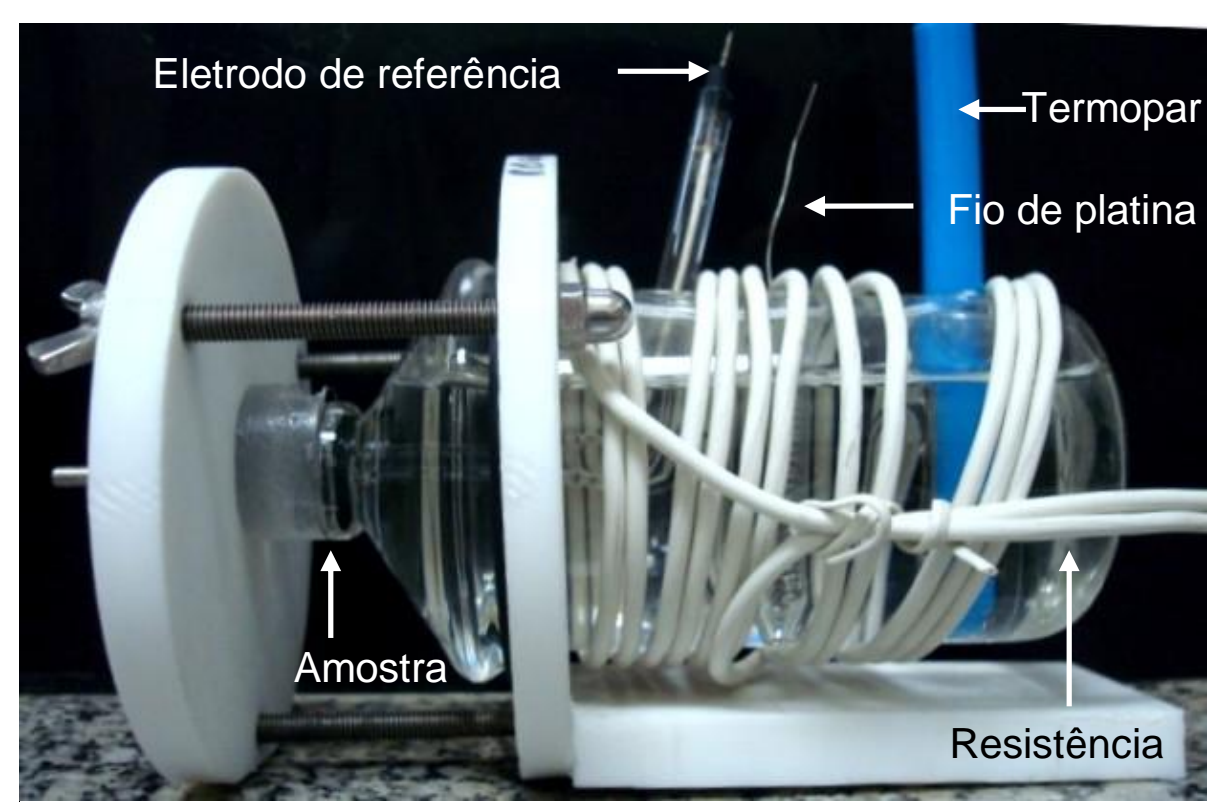

Figura 15 - Célula eletroquímica com arranjo de três eletrodos. 


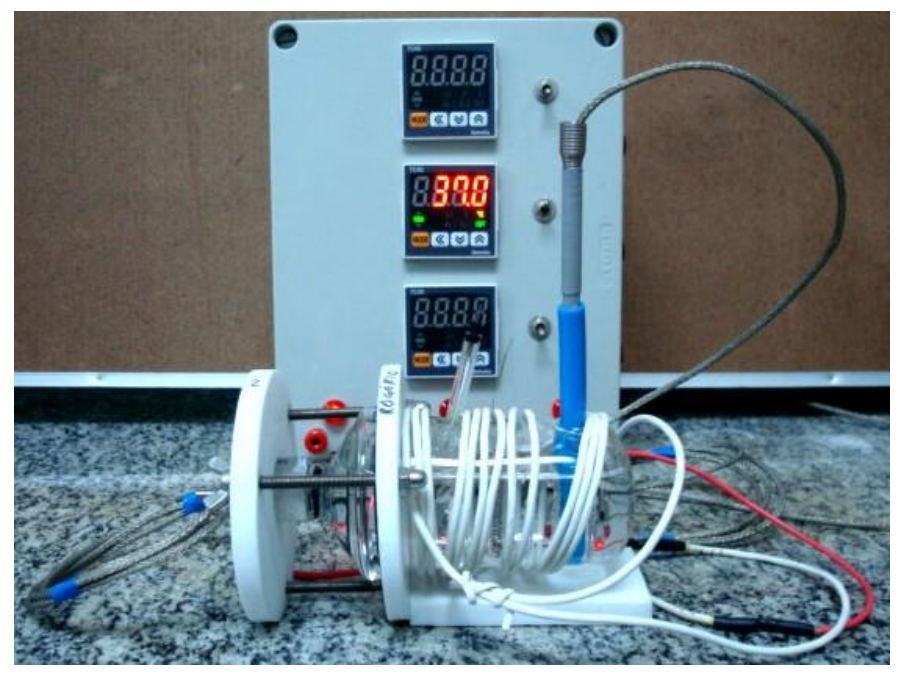

Figura 16 - Célula eletroquímica conectada ao sistema de aquecimento com controlador de temperatura digital microprocessado.

Para todos os ensaios eletroquímicos, utilizou-se um potenciostato Gamry PCl4/3000 com analisador de resposta em frequências integrado.

\subsubsection{Potencial de circuito aberto}

A variação do potencial de circuito aberto, em função do tempo, foi monitorada para as amostras dos aços inoxidáveis AISI 444, AISI 444S, NeoM e ISO 5832-1, durante 48 horas, em solução naturalmente aerada de PBS a $37^{\circ} \mathrm{C}$.

\subsubsection{Espectroscopia de impedância eletroquímica (EIE)}

Os aços inoxidáveis AISI 444, AISI 444S, NeoM e ISO 5832-1 foram investigados quanto ao comportamento eletroquímico, em função do tempo, em solução PBS a $37^{\circ} \mathrm{C}$. Os espectros de impedância foram obtidos após 2, 7, 14 e 21 dias de imersão. As medidas de EIE foram realizadas no potencial de circuito aberto, utilizando-se um sinal senoidal com amplitude de $10 \mathrm{mV}$, na faixa de frequências de $100 \mathrm{kHz}$ até $10 \mathrm{mHz}$, com taxa de aquisição de dados de 10 pontos por década. Os diagramas de EIE foram ajustados com CEE utilizando o software Zview.

\subsubsection{Polarização anódica potenciodinâmica cíclica}

As curvas de polarização anódica, para os aços inoxidáveis AISI 444, AISI 444S, NeoM e ISO 5832-1, foram obtidas potenciodinamicamente, após 2 e 21 dias de imersão em solução PBS a $37^{\circ} \mathrm{C}$. A taxa de varredura foi de $1 \mathrm{mV} . \mathrm{s}^{-1}$, 
partindo-se do potencial de circuito aberto, com reversão de direção ao se atingir a densidade de corrente limite de $10^{-3} \mathrm{~A} \cdot \mathrm{cm}^{-2}$.

4.2.4.4 Gráficos de Mott-Schottky - Propriedades eletrônicas do filme passivo

A abordagem de Mott-Schottky foi utilizada para comparar as propriedades eletrônicas dos filmes passivos formados sobre os aços inoxidáveis AISI 444 e NeoM. A superfície das amostras foi preparada por lixamento com papel de carbeto de silício até grana \#2000, seguido por polimento com pasta de diamante até $1 \mu \mathrm{m}$. Imergiu-se em solução PBS, a $37^{\circ} \mathrm{C}$ e, após 2, 7, 14 e 21 dias, obtiveram-se os resultados experimentais.

As medidas foram realizadas na frequência de $1 \mathrm{kHz}$, com aplicação da polarização em incrementos sucessivos de $-50 \mathrm{mV}_{\text {Ag/AgCl }}$ no sentido catódico. As faixas de potencial investigadas foram de $+500 \mathrm{mV}_{\mathrm{Ag} / \mathrm{AgCl}}$ até $-1000 \mathrm{mV}_{\mathrm{Ag} / \mathrm{AgCl}}$, para as amostras $\mathrm{NeoM}$, e de $+500 \mathrm{mV}_{\mathrm{Ag} / \mathrm{AgCl}}$ até $-1500 \mathrm{mV}_{\mathrm{Ag} / \mathrm{AgCl} \text {, para as do aço AISI }}$ 444.

Pelos diagramas de Mott-Schottky obteve-se a concentração de dopantes $\mathrm{N}_{\mathrm{q}}$. Os valores de $\mathrm{N}_{\mathrm{q}}$ representam as densidades de doadores $\left(\mathrm{N}_{\mathrm{D}}\right)$ ou aceitadores de carga $\left(\mathrm{N}_{\mathrm{A}}\right)$ para um semicondutor tipo-n ou tipo-p. Para o cálculo de $N_{q}$ empregou-se os seguintes valores: $q=1,602.10^{-19} \mathrm{C} ; \varepsilon_{0}=8,85.10^{-14} \mathrm{~F} . \mathrm{cm}^{2}$ (MARTINI e MULLER, 2000); $\varepsilon=12$, tanto para a camada passiva interna de óxido de cromo, quanto para a externa rica em óxidos de ferro (AHN e KWON, 2004 e LOVRECEK e SEFAJA, 1972). Sabendo-se que a inclinação da reta, calculada por regressão linear a partir dos gráficos de Mott-Schottky, corresponde ao termo $\frac{2}{\varepsilon \varepsilon_{0} \mathrm{eN}}$ da Equação 2, obtiveram-se os valores de $\mathrm{N}_{\mathrm{q}}$ para os doadores $\mathrm{e}$ aceitadores de cargas.

\subsubsection{Ensaios eletroquímicos em condição de fresta}

A corrosão em regiões de fresta representa uma condição mais agressiva do que o arranjo eletroquímico anteriormente exposto (Figura 15). Neste trabalho desenvolveu-se um sistema para investigar o efeito da condição de fresta na resistência à corrosão do aço inoxidável ferrítico AISI 444. Para tanto, foi projetado e montado o equipamento mostrado na Figura 17, o qual permitiu criar uma região de fresta entre a amostra e o contracorpo. 


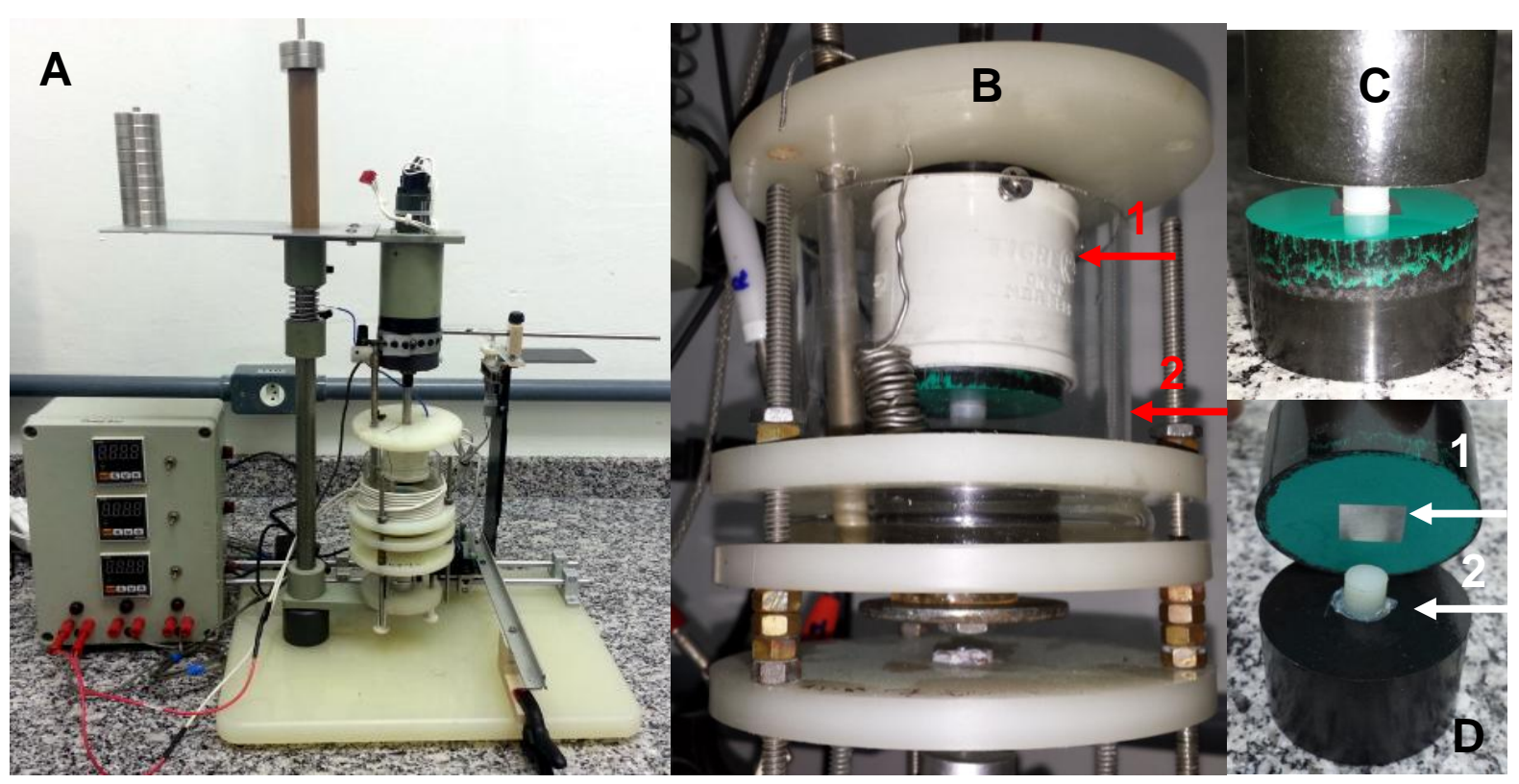

Figura 17 - A) Equipamento para simulação de corrosão em condição de fresta; B) Porta amostra (seta 1) e célula eletroquímica (seta 2); C e D) Amostra embutida (seta 1) e contracorpo (seta 2).

Para o desenvolvimento deste equipamento estudou-se os modelos propostos por outros autores ou os padronizados em normas. A partir disto, projetou-se a estrututra dos suportes, célula eletroquímica, sistema de aquecimento, mecanismo de carga, sistema de fixação da amostra, contracorpo com cilindro delimitador da região de oclusão e sistema de nivelamento das amostras. A preparação da amostra exigiu muita atenção, a fim de que todos os corpos de prova tivessem a mesma área exposta ao meio. $O$ polimento sem abaulamento da superfície da amostra só foi possível com a utilização de um equipamento automatizado de preparação de amostras (modelo Tegramin-20, Struers - Alemanha). Outro recurso incorporado ao sistema, mas não explorado neste trabalho, foi um mecanismo de movimentação entre a amostra e o contracorpo, o qual possibilitará estudos futuros de corrosão associada ao desgaste abrasivo.

Amostras dos aços inoxidáveis AISI 444 e ISO 5832-1, com área de $1,44 \mathrm{~cm}^{2}$, foram embutidas em baquelite e polidas com pasta diamantada até $1 \mu \mathrm{m}$ (Figura 17D). Confeccionou-se um contracorpo de baquelite com um cilindro de 7 $\mathrm{mm}$ de diâmetro, feito em polietileno de ultra alto peso molecular (PEUAPM), fixado em seu centro. As amostras foram mantidas em contato com o contracorpo (Figura 17C), formando a região de fresta (Figura 17B). Carregou-se o conjunto com $230 \mathrm{~g}$ e imergiu-se com solução de PBS a $37^{\circ} \mathrm{C}$, naturalmente aerada. 
Monitorou-se o potencial de circuito aberto por 72 horas. As curvas de EIE foram obtidas para 2 e 7 dias de imersão. As medidas de EIE foram realizadas no potencial de circuito aberto, utilizando-se um sinal senoidal com amplitude de 10 $\mathrm{mV}$, na faixa de frequências de $100 \mathrm{kHz}$ até $10 \mathrm{mHz}$ e com taxa de aquisição de dados de 10 pontos por década. As curvas de polarização anódica potenciodinâmicas cíclicas foram obtidas após 2 dias de imersão, em solução de PBS a $37 \stackrel{\circ}{\circ}$. A taxa de varredura foi de $1 \mathrm{mV} . \mathrm{s}^{-1}$, partindo-se do potencial de circuito aberto. A reversão da direção de varredura ocorreu ao atingir a densidade de corrente limite de $10^{-3} \mathrm{~A} . \mathrm{cm}^{-2}$. 


\section{RESULTADOS E DISCUSSÃO}

\subsection{Caracterização dos materiais}

\subsubsection{Aço inoxidável austenítico ISO 5832-1}

$\mathrm{Na}$ Tabela 7 são apresentados os resultados da análise química realizada (ICP-OES pela Mangels Ind. e Com. LTDA e Leco pela USIMINAS) e os valores de composição fornecidos pelo fabricante (Villares Metals).

Tabela 7 - Análise química (\% em massa) dos principais elementos de liga do aço ISO 5832-1

\begin{tabular}{lccccccccccc}
\hline & $\mathbf{C r}$ & $\mathbf{N i}$ & $\mathbf{M o}$ & $\mathbf{M n}$ & $\mathbf{S i}$ & $\mathbf{N b}$ & $\mathbf{T i}$ & $\mathbf{N}$ & $\mathbf{S}$ & $\mathbf{C}$ & $\mathbf{F e}$ \\
\hline Nominal & $17,0-$ & $13,0-$ & $2,25-$ & $\leq 2,0$ & $\leq 1,0$ & - & - & $\leq 0,10$ & $\leq 0,010$ & $\leq 0,030$ & bal. \\
& 19,0 & 15,0 & 3,0 & & & & & & & & \\
\hline Analisado & 18,32 & 14,33 & 2,59 & 2,09 & 0,37 & 0,33 & 0,009 & 0,047 & 0,008 & 0,023 & bal. \\
& $\pm 0,9$ & $\pm 0,4$ & $\pm 0,2$ & $\pm 0,2$ & $\pm 0,2$ & $\pm 0,1$ & $\pm 0,01$ & $\pm 0,02$ & $\pm 0,003$ & $\pm 0,005$ & \\
\hline
\end{tabular}

A porcentagem em massa dos elementos analisados está de acordo com as especificações da norma ISO 5832-1. A microestrutura foi revelada por meio de ataque eletrolítico com ácido oxálico 10\%. A micrografia (Figura 18) confirmou uma estrutura típica austenítica com presença de maclas e grãos axiais.

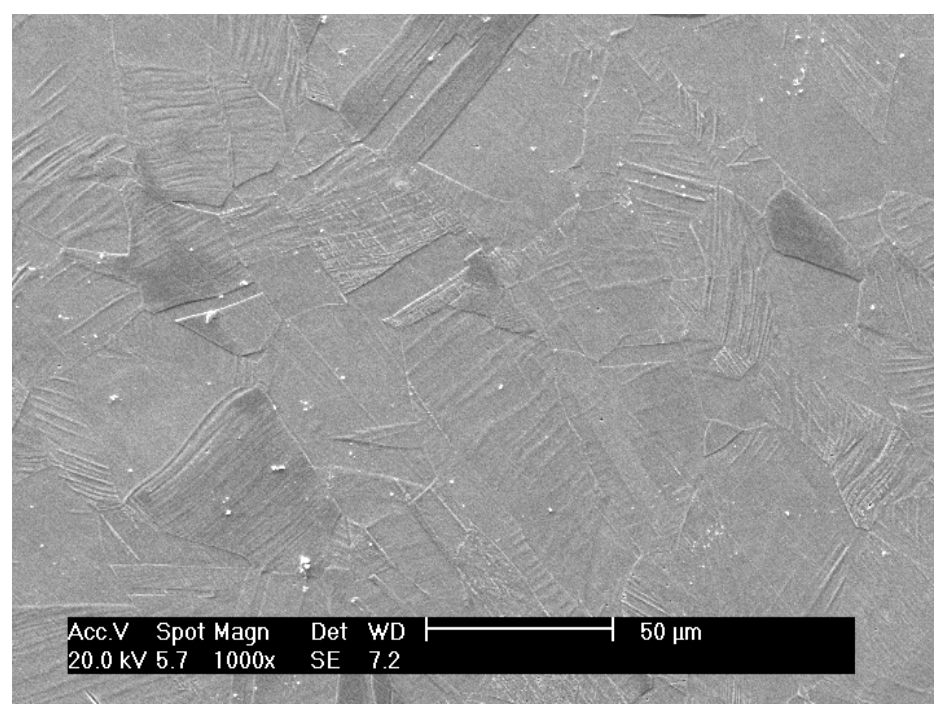

Figura 18 - MEV do aço inoxidável ISO-5832-1, após ataque eletrolítico com ácido oxálico $10 \%$.

O material, conforme recebido, foi observado por MEV e as micrografias são mostradas na Figura 19. O acabamento superficial, dado pelo fabricante, não foi alterado por ser o mesmo padrão utilizado nas próteses ortopédicas. 
A

B

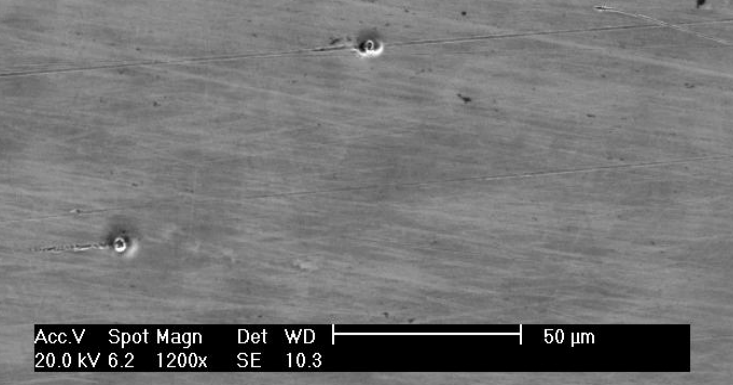

Figura 19 - A) Micrografia obtida por MEV da superfície do aço ISO 5832-1 como recebido. B) Idem com maior magnificação.

Observa-se uma superfície não homogênea, com presença de riscos, além de alguns pontos claros e escuros. Estes pontos foram identificados como inclusões e sítios de arrancamento durante o polimento. Na Figura 20A observase a microcavidade onde estava um precipitado que foi arrancado. A análise por EDS (Figura 20B) da superfície indicou picos condizentes com o metal base (Figura 35A).
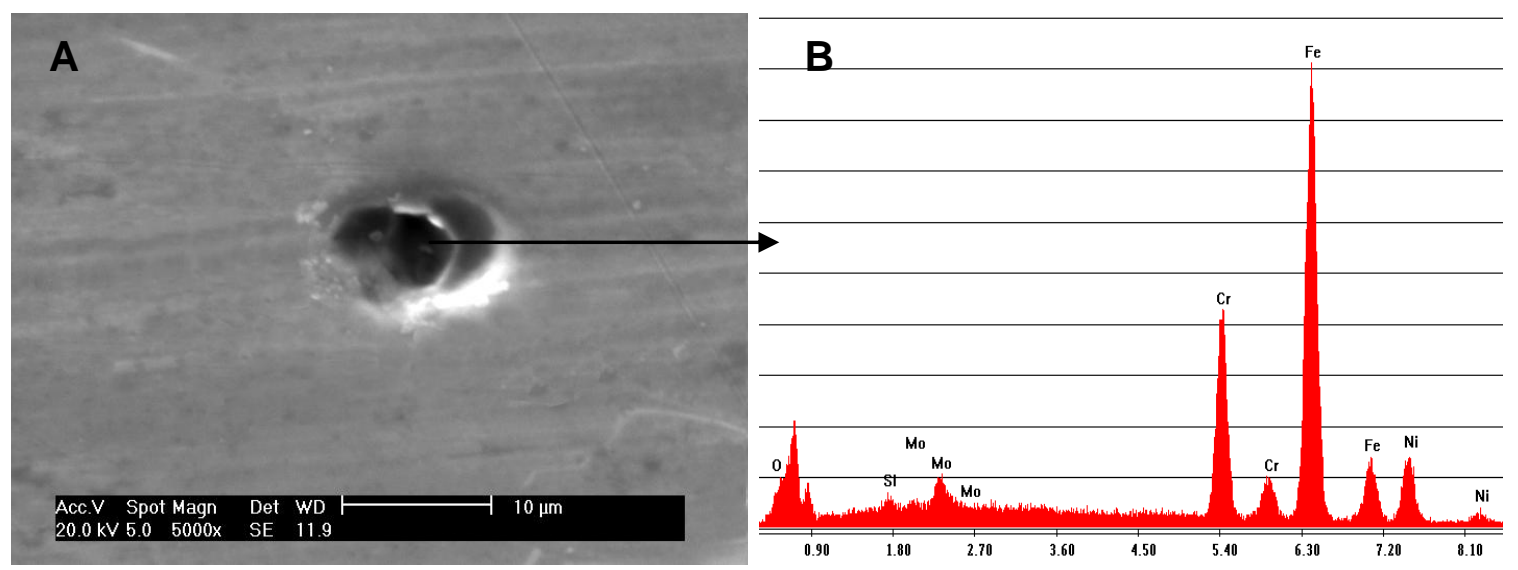

Figura 20 - Micrografia por MEV do aço ISO 5832-1, conforme recebido. A) região de arrancamento de inclusão. B) EDS do local indicado pela seta.

Foi feita a caracterização dos precipitados encontrados no aço ISO5832-1, sendo as amostras polidas por lixamento com papel de carbeto de silício até grana \#2000, seguido por polimento com pasta de diamante até $1 \mu \mathrm{m}$. As micrografias, com os repectivos espectros por EDS, são apresentadas nas figuras 21,22 e 23. 


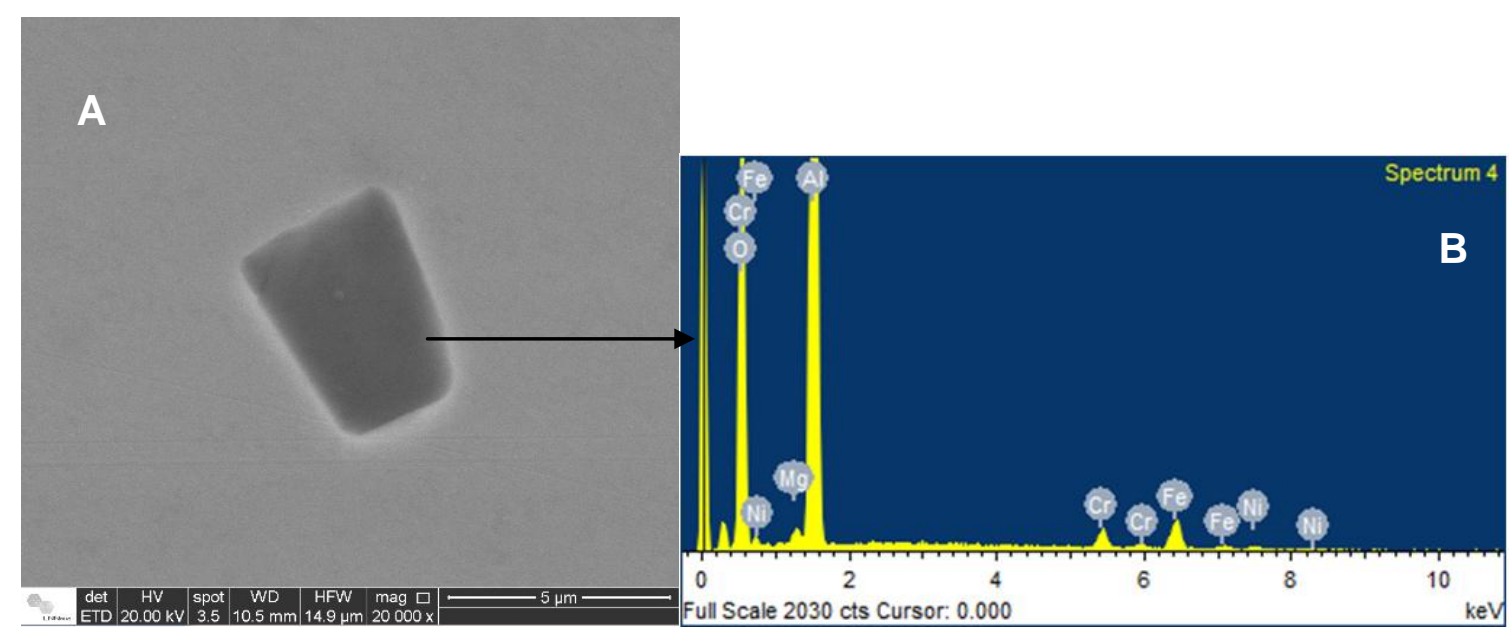

Figura 21 - Micrografia por MEV do aço ISO 5832-1, após polimento metalográfico, mostrando a presença de inclusão. A) MEV. B) EDS.

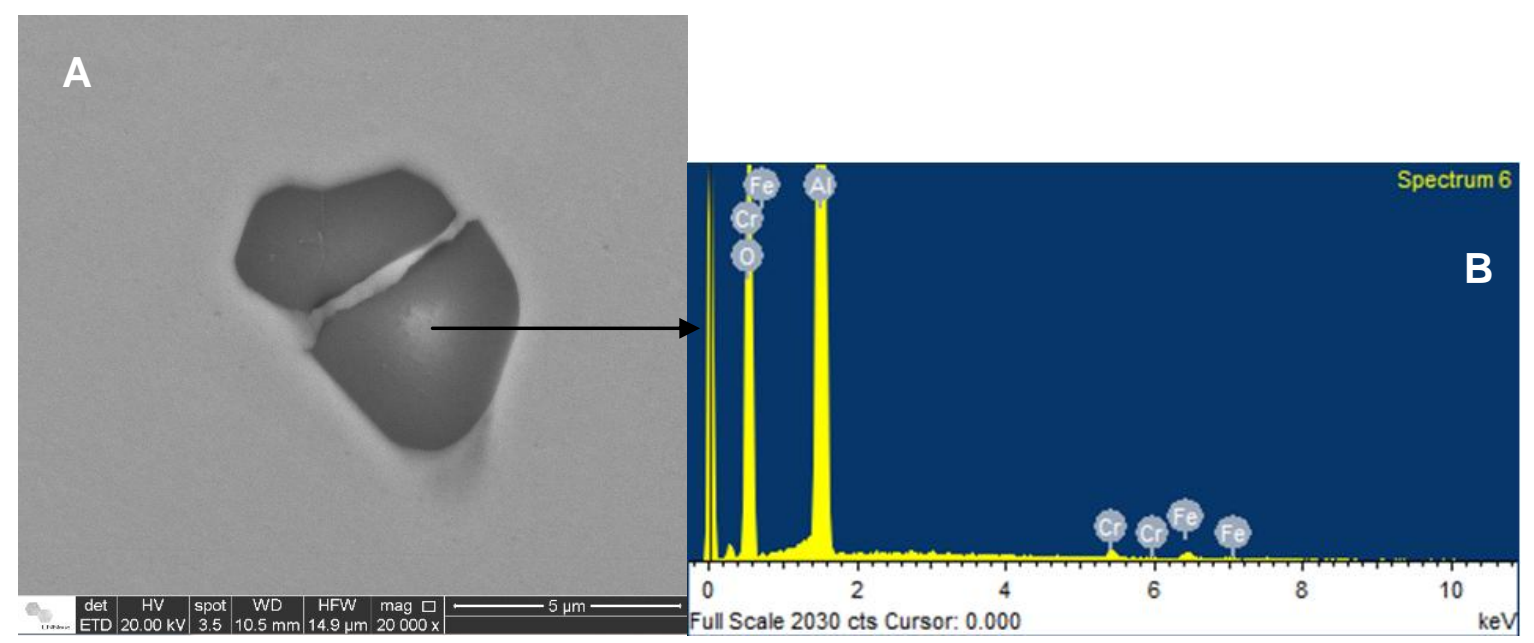

Figura 22 - Micrografia por MEV do aço ISO 5832-1, após polimento metalográfico, mostrando a presença de inclusão. A) MEV. B) EDS.

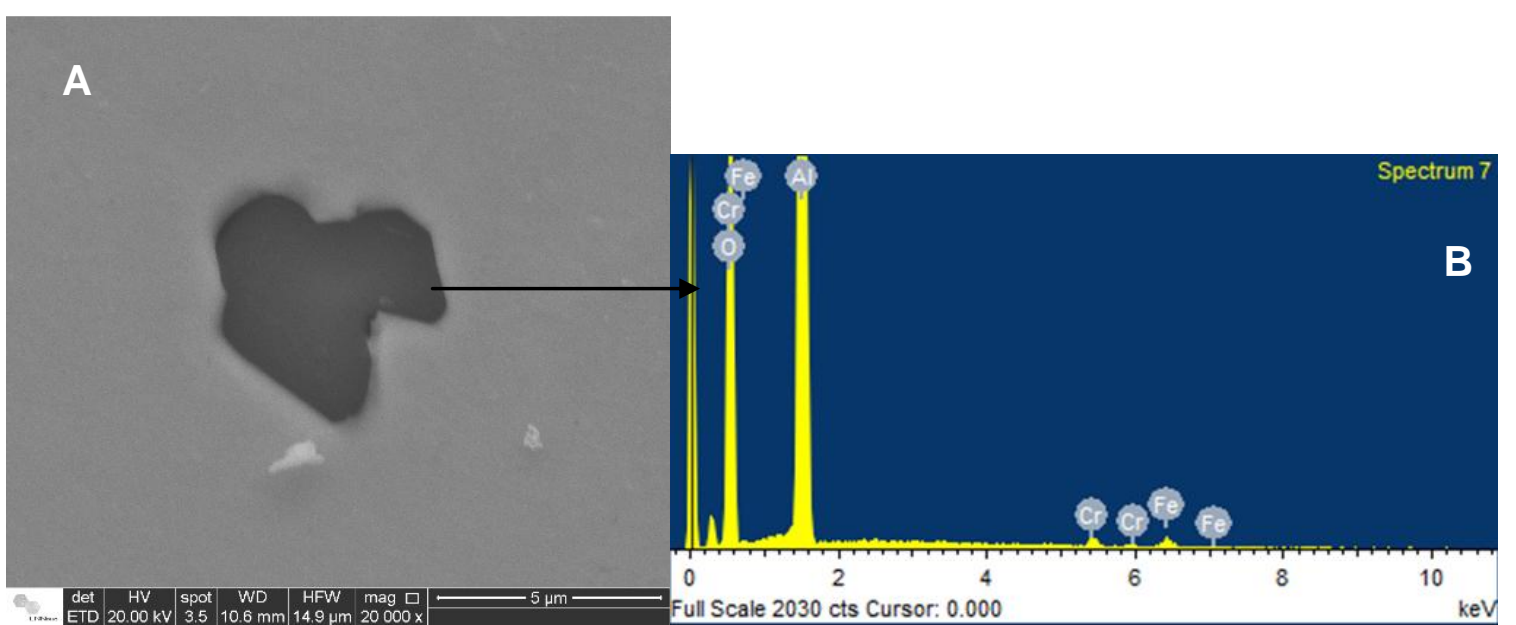

Figura 23 - Micrografia por MEV do aço ISO 5832-1, após polimento metalográfico, mostrando a presença de inclusão. A) MEV. B) EDS

As micrografias do aço ISO 5832-1 mostraram a presença de inclusões de morfologia variável, porém todos os espectros de EDS indicaram uma composição química similar, com a presença de ferro, cromo, alumínio e oxigênio. 
O ferro e o cromo são provenientes da matriz, logo estas são inclusões contendo alumina, resultantes do processo de fabricação da liga.

\subsubsection{Aço inoxidável ferrítico AISI 444}

A Tabela 8 mostra os resultados da análise química e os valores fornecidos pelo fabricante. A análise química foi realizada por Espectroscopia de Absorção Atômica por Chama (EAAS) e os resultados são a média de 20 leituras.

Tabela 8 - Análise química (\% em massa) dos principais elementos de liga do aço AISI 444

\begin{tabular}{lccccccccc}
\hline & $\mathbf{C r}$ & $\mathbf{N i}$ & $\mathbf{M o}$ & $\mathbf{M n}$ & $\mathbf{S i}$ & $\mathbf{N b}+\mathbf{T i}$ & $\mathbf{S}$ & $\mathbf{C}$ & $\mathbf{F e}$ \\
\hline Nominal & $17,5-19,5$ & $\leq 1,00$ & $1,75-2,50$ & $\leq 1,00$ & $\leq 1,00$ & $\leq 0,80$ & $\leq 0,030$ & $\leq 0,025$ & bal. \\
\hline Analisado & 16,27 & 0,50 & 1,99 & 0,13 & 0,58 & 0,44 & 0,015 & 0,013 & bal. \\
& $\pm 0,4$ & $\pm 0,2$ & $\pm 0,2$ & $\pm 0,05$ & $\pm 0,2$ & $\pm 0,1$ & $\pm 0,01$ & $\pm 0,01$ & \\
\hline
\end{tabular}

Este material foi produzido segundo a especificação AISI 444 (UNS S4400) da norma ASTM A240, onde o teor de Cr deve ficar entre 17,5 e 19,5 \% (em massa). Portanto, pelo analisado, o cromo está $0,8( \pm 0,4) \%$ abaixo da norma. Os demais elementos estão de acordo com o especificado para o aço AISI 444.

$\mathrm{Na}$ Figura 24A, observa-se a micrografia por MEV do aço inoxidável ferrítico AISI 444, após ataque metalográfico com o reagente Villela, o qual revelou uma microestrutura típica de aços ferríticos. Na Figura 24B são mostradas, de forma geral, inclusões encontradas na microestrutura deste aço. Pode-se observar uma baixa densidade de inclusões e o alinhamento destas, provavelmente, no sentido de laminação do material.

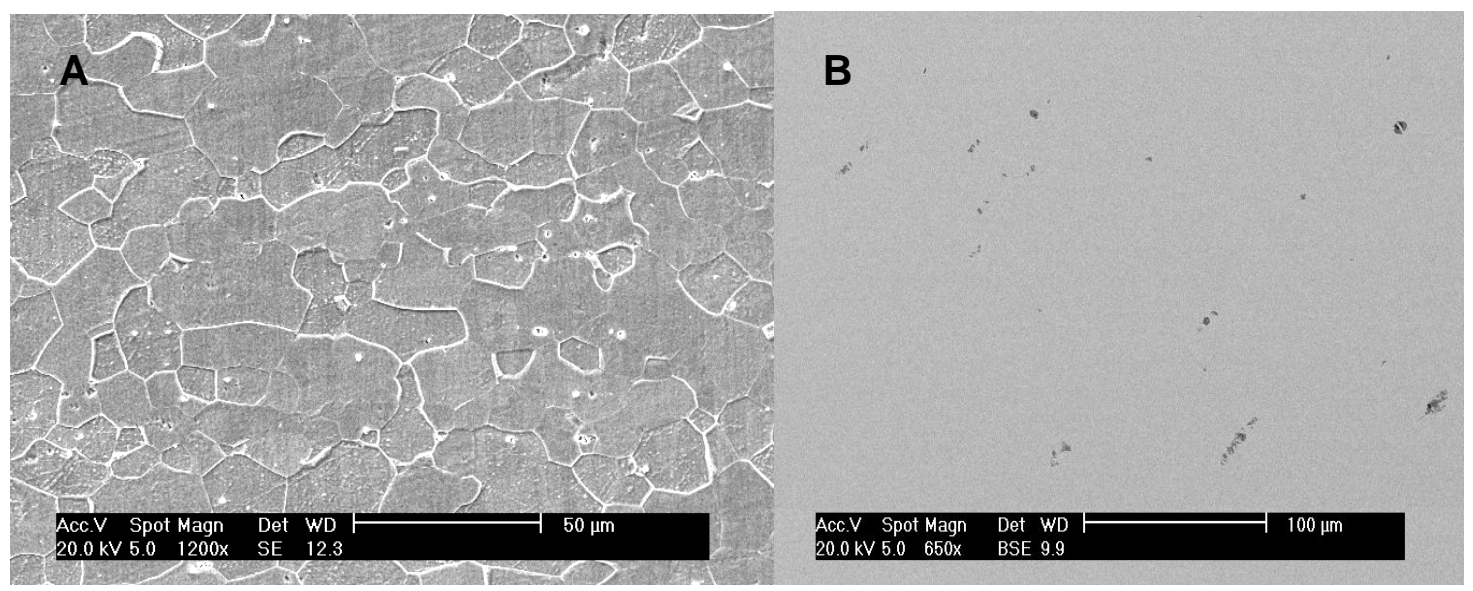

Figura 24 - Microestrutura do aço AISI 444, como recebido. A) Após ataque com reagente Villela. B) Sem ataque.

A caracterização das inclusões, observadas na Figura 24, foi feita por EDS visando determinar a composição química das mesmas. Os resultados são 
apresentados nas Figuras 25, 26 e 27. A análise por EDS do metal base é apresentada, mais adiante, na Figura 35B.
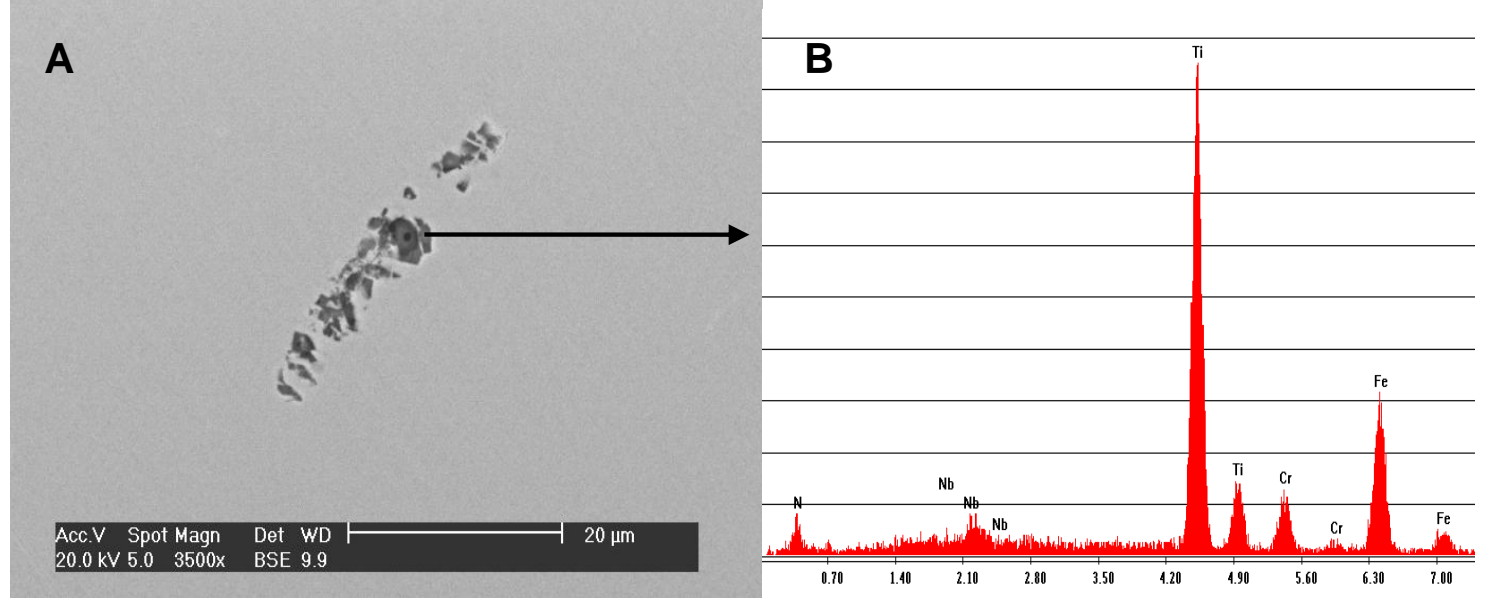

Figura 25 - A) Micrografia obtida por MEV. B) Análise por EDS de região do aço AISI 444 com inclusão rica em Ti e Nb.

Na micrografia da Figura 25, observa-se uma inclusão com formato irregular que, possivelmente, foi quebrada pelo processo de laminação. A análise por EDS mostrou que esta fase é rica em titânio além de conter nióbio. O ferro e o cromo aparecem devido à interferência da matriz. O titânio e o nióbio são adicionados a esta liga com finalidade de evitar a precipitação de carbonetos de cromo e previnir a remoção de cromo da matriz. Estes compostos são provavelmente nitretos de titânio e nióbio.

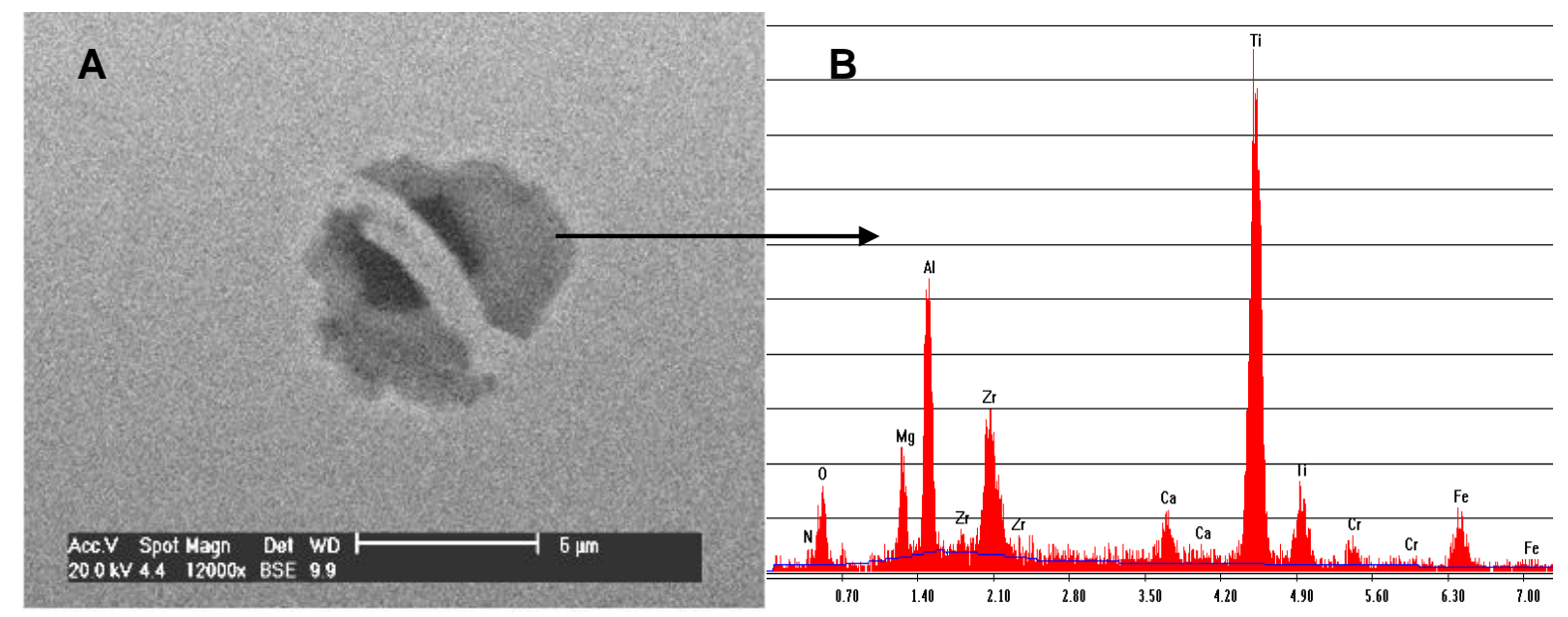

Figura 26 - A) Micrografia obtida por MEV. B) Análise por EDS de região do aço AISI 444 com inclusão rica em $\mathrm{Ti}, \mathrm{Al}, \mathrm{Zr}, \mathrm{Ca}$ e Mg.

A Figura 26 apresenta uma inclusão contendo duas regiões distintas. Uma mais clara (borda) e outra mais escura (no centro). Ambas são atravessadas por material da matriz. A variação de coloração, entre as diversas partes da 
inclusão, indica uma diferença significativa na composição química desta. Devido ao tamanho reduzido desta inclusão não foi possível analisar por EDS, separadamente, as duas regiões. O EDS mostrou que se trata de uma inclusão rica em $\mathrm{Al}$ e $\mathrm{Ti}$, com menores porcentagens de zircônio, magnésio e cálcio. $\mathrm{O}$ magnésio e cálcio são resíduos de escória. Pode-se concluir que é uma inclusão mista, composta de óxidos com carboneto ou nitreto de titânio.

A micrografia da Figura 27 mostrou uma inclusão com formato retangular, cuja análise por EDS indicou um pico de silício, além dos elementos cromo e ferro, oriundos da matriz. O EDS sugere que esta inclusão é uma partícula de sílica $\left(\mathrm{SiO}_{2}\right)$.

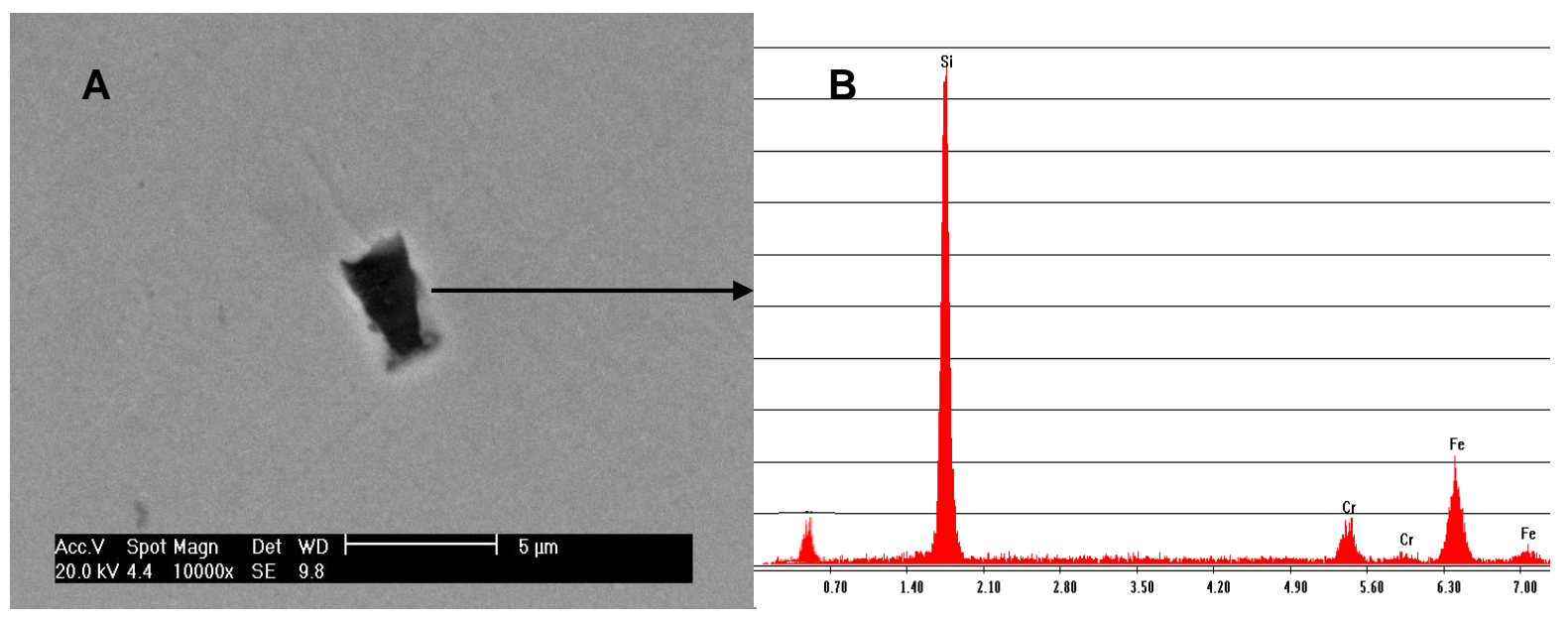

Figura 27 - A) Micrografia por MEV. B) Análise por EDS da região do aço AISI $444 \mathrm{com}$ inclusão rica em Si.

Em aços como o AISI 444, que contêm adições de $\mathrm{Nb}$ ou $\mathrm{Ti}$ (aços estabilizados), os carbonetos e nitretos de cromo são parcial ou completamente substituídos pelos de nióbio ou de titânio. Estes precipitados são mais estáveis que os de Cr por apresentarem menor solubilidade, uma vez que só se dissolvem na matriz ferrítica em temperaturas superiores a $1200{ }^{\circ} \mathrm{C}$. Consequentemente, os aços estabilizados tendem a manter uma estrutura completamente ferrítica até a temperatura de fusão (MODENESI, 2001, FOLKHARD, 1988).

$\mathrm{Na}$ micrografia do aço AISI 444 (Figura 28), pode-se verificar a presença de um precipitado contendo nióbio e titânio, conforme indicado pela análise por EDS da região sinalizada pela seta. 


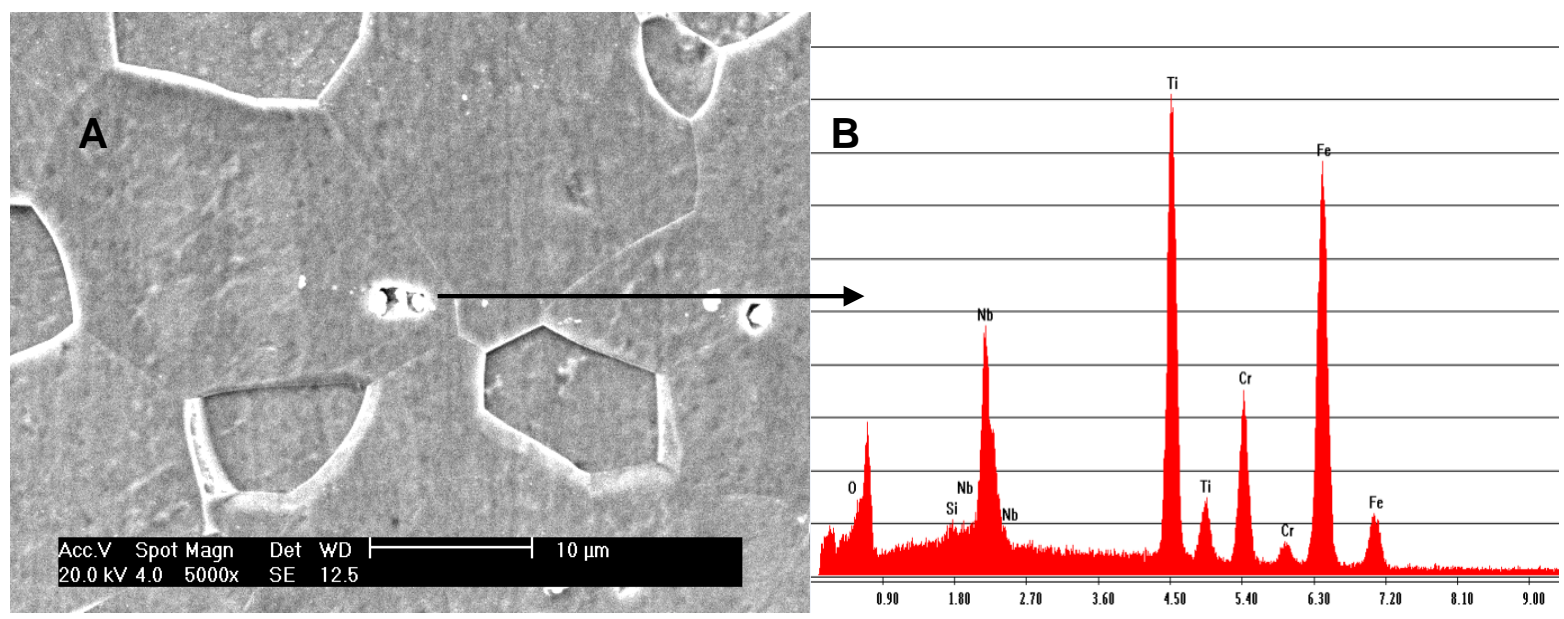

Figura 28 - A) Micrografia por MEV do aço AISI 444. B) Análise por EDS evidenciando a presença de precipitado rico em $\mathrm{Ti}$ e $\mathrm{Nb}$.

Nos aços ferríticos, os elementos intersticiais ( $\mathrm{C}$ e $\mathrm{N}$ ) tendem a formar precipitados de carbonetos e nitretos, dependendo da temperatura. Quando o teor de intersticiais $(\mathrm{C}+\mathrm{N})$ for superior a $0,01 \%$, dependendo da taxa de resfriamento, os carbonetos e nitretos tendem a se formar novamente. O tamanho, a quantidade, a distribuição e a condição de formação, destes precipitados, têm um importante efeito nas propriedades mecânicas e químicas da liga (MODENESI, 2001). Em temperatura de $1050^{\circ} \mathrm{C}$, a solubilização promove uma mudança na distribuição e na fração volumétrica de precipitados, o que favorece o crescimento de grãos (THOMAS \& ROBINSON, 1978). Este efeito pôde ser observado na micrografia óptica do aço inoxidável AISI 444, antes e após solubilização a 1050 $\stackrel{\circ}{ }$, por 30 minutos (Figura 29).

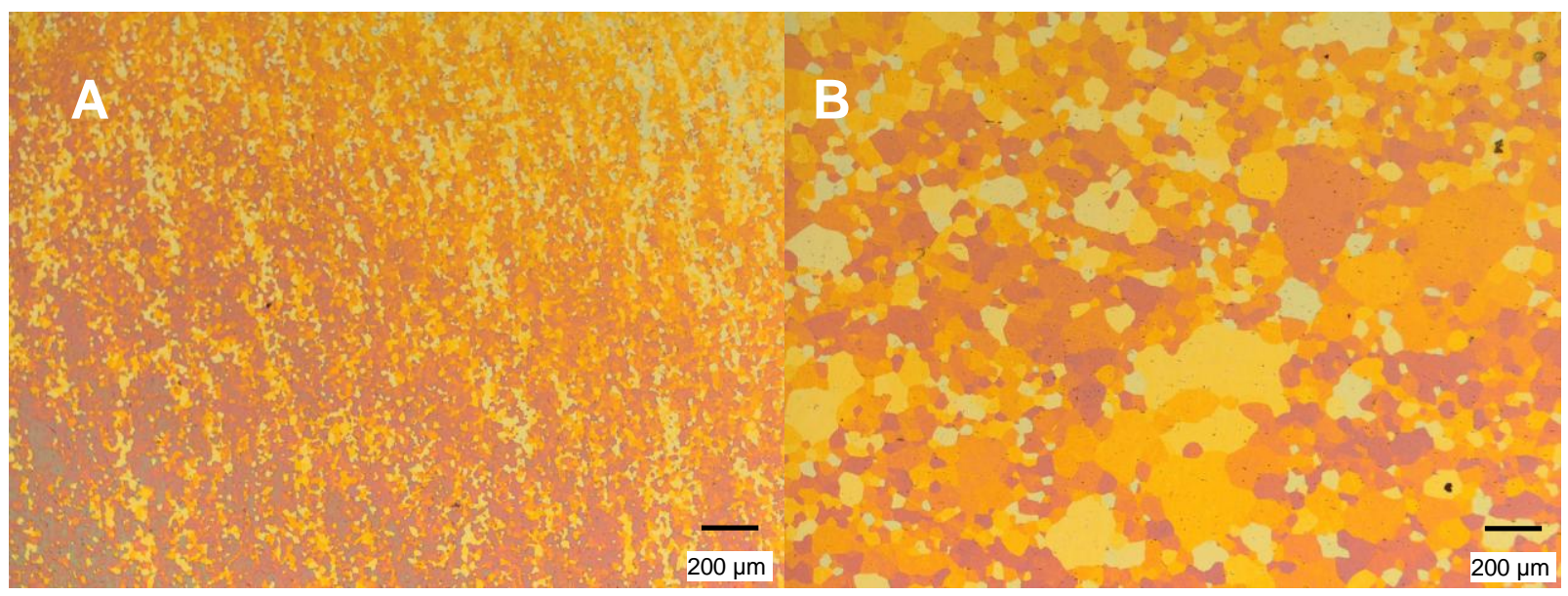

Figura 29 - Micrografia obtida por microscopia óptica do aço AISI 444. A) Como recebido; B) Após solubilização a $1050 \stackrel{\circ}{\mathrm{C}}$, durante 30 minutos. Ataque eletrolítico: $\mathrm{NaOH} 30 \%$. 
Comparando-se as micrografias da Figura 29, observou-se que 0 tratamento de solubilização causou crescimento expressivo de grãos. O efeito deste tratamento de solubilização, na resistência à corrosão, foi investigado.

\subsubsection{Aço inoxidável Neo Magnet}

A Tabela 9 apresenta a composição química obtida por ICP-OES (LAQA-IPEN) e a estabelecida pela norma JIS para o aço SUS 444.

Tabela 9 - Composição química analisada do aço NeoM (\% em massa) e estabelecida pela norma JIS para o aço SUS 444.

\begin{tabular}{lccccccccccc}
\hline & $\mathbf{C r}$ & $\mathbf{N i}$ & $\mathbf{M o}$ & $\mathbf{M n}$ & $\mathbf{S i}$ & $\mathbf{C}$ & $\mathbf{S}$ & $\mathbf{P}$ & $\mathbf{T i}+\mathbf{N b}$ & $\mathbf{F e}$ \\
\hline SUS 444 & $17,5-$ & $\leq 1,0$ & $1,75-$ & $\leq 1,0$ & $\leq 1,0$ & $\leq 0,025$ & $\leq 0,03$ & $\leq 0,04$ & $\leq 0,8$ & bal. \\
\hline Analisado & 19,5 & 13,2 & 3,11 & 0,34 & 1,34 & 1,10 & ${ }^{*}$ & ${ }^{*}$ & 0,04 & 0,30 & bal. \\
\hline
\end{tabular}

*não quantificado

Os resultados da análise química revelaram que a liga, usada para fabricação do componente magnético (NeoM), apresentou os teores de $\mathrm{Ni}, \mathrm{Cr}$, Mo, Mn e Si fora da norma. Esta diferença de composição sugere possíveis efeitos deletérios quanto as propriedades físico-químicas deste aço, dentre elas a resistência à corrosão.

Com a finalidade de revelar a microestrutura do aço NeoM, utilizou-se ataques metalográficos com água régia, Nital (3\% e 10\%), Villela, Berzelius, Picral, $\mathrm{NaOH} 30 \%$ eletrolítico (6V por 20s) e um reagente composto por $90 \%$ $\mathrm{H}_{2} \mathrm{O}, 7 \% \mathrm{HCl}$ e $3 \% \mathrm{HNO}_{3}$. Contudo, em nenhum destes ataques foi possível ter certeza que a microestrutura foi revelada. $O$ melhor resultado foi obtido com ataque eletrolítico em $\mathrm{NaOH} 30 \%$, conforme observado na Figura 30.

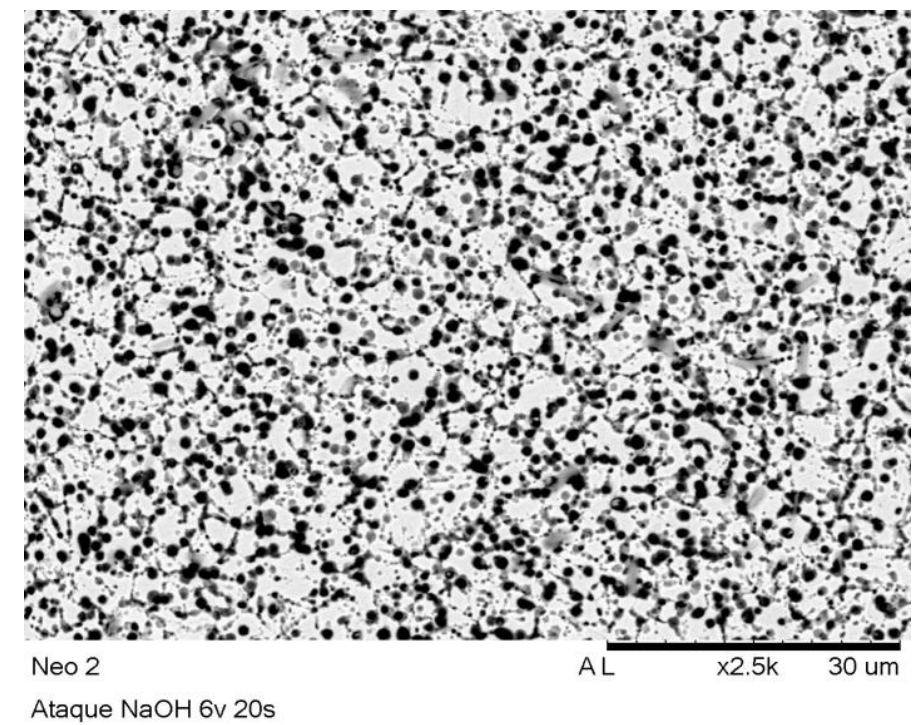

Figura 30 - Micrografia por MEV do aço NeoM, após ataque eletrolítico em $\mathrm{NaOH}$ $30 \%$ (6V por 20 s). 
A Figura 30 apresentou uma microestrutura de um aço inoxidável ferrítico (região clara) com grande quantidade de inclusões e regiões de arrancamento de precipitados/inclusões (regiões esféricas escuras). Observou-se que as regiões mais escuras, com diametro de 1 a 3 micra, estão próximas dos contornos de grão e correspondem às áreas mais acometidas, após o ataque metalográfico.

Amostras embutidas e apenas polidas também foram analisadas por MEV. A área observada corresponde à parte circular superior do componente (Figura 31A). Na Figura 31B é possível observar, de forma geral, as inclusões presentes na microestrutura do aço NeoM.

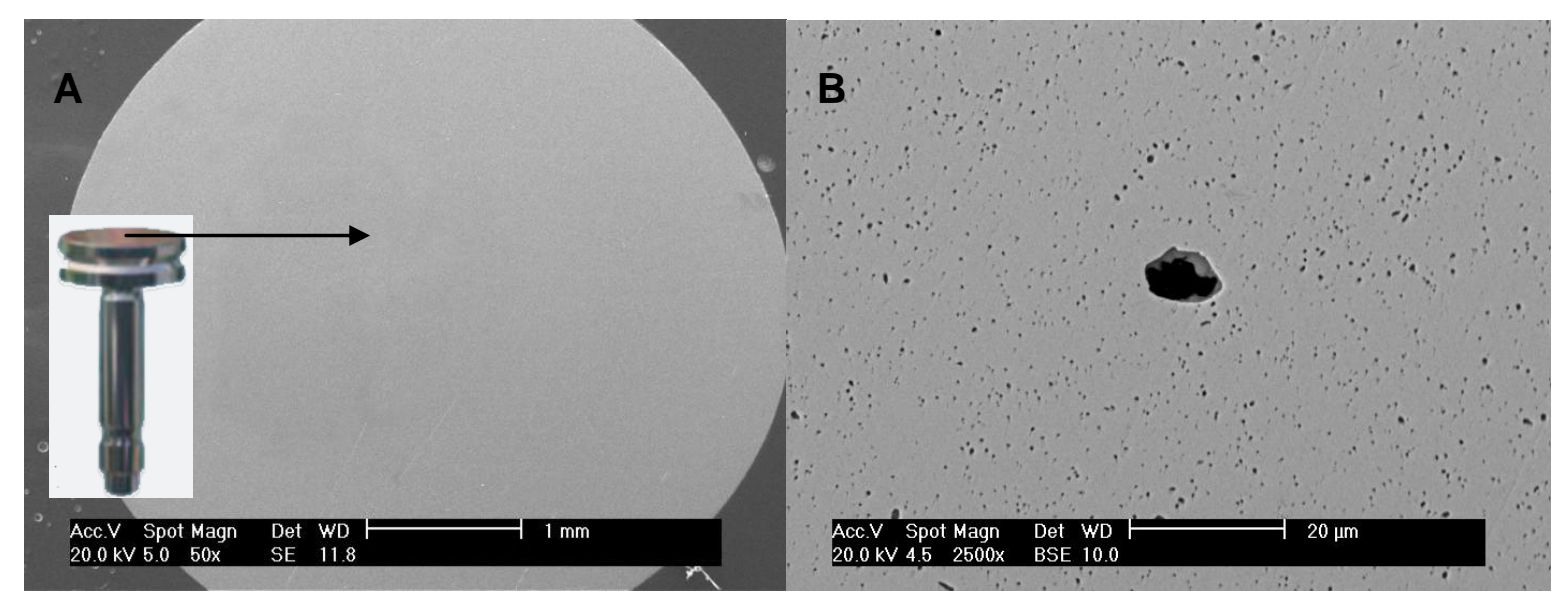

Figura 31 - Micrografia do aço NeoM como recebido. A) Componente NeoM e micrografia da amostra embutida B) Maior aumento mostrando grande quantidade de inclusões.

Os pontos de precipitados e/ou inclusões são visualizados em maior aumento nas Figuras 32, 33 e 34. Foram realizadas análises por EDS sobre estas inclusões e os espectros obtidos são mostrados nas respectivas figuras. 0 espectro obtido por EDS do metal base é apresentado, mais adiante, na Figura $35 \mathrm{C}$. 


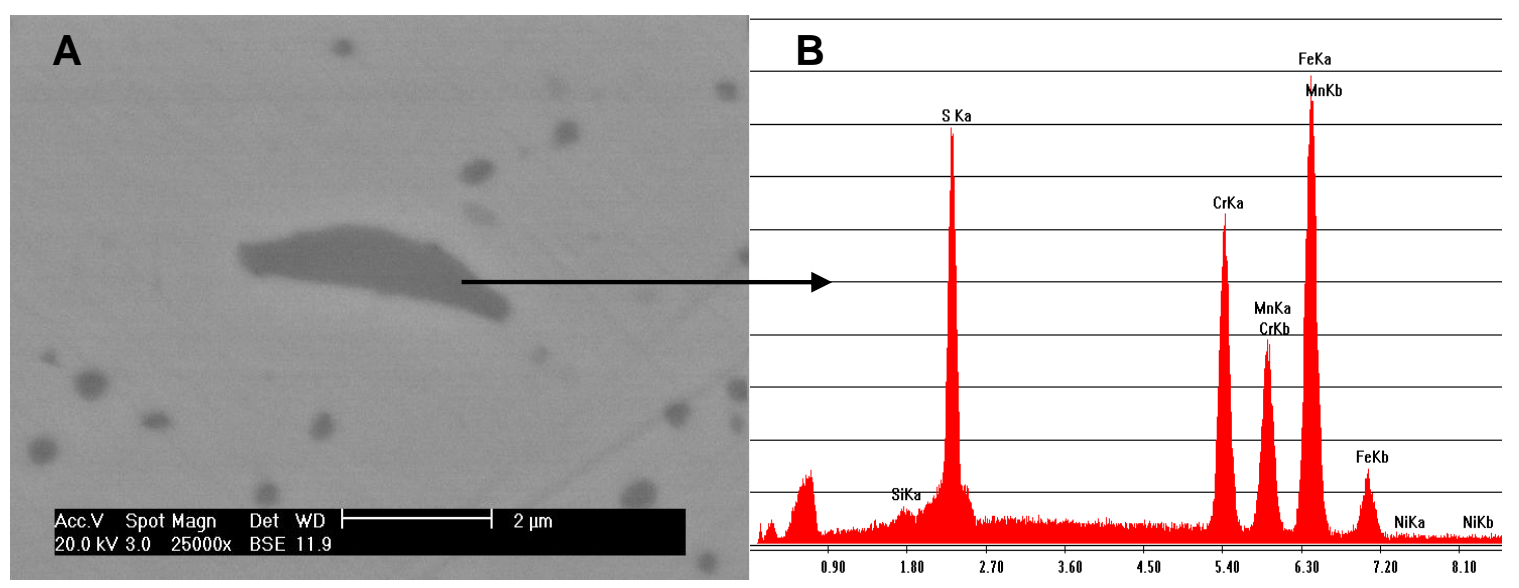

Figura 32 - Região de uma inclusão de sulfeto de manganês na liga NeoM. A) MEV; B) EDS da região indicada pela seta.

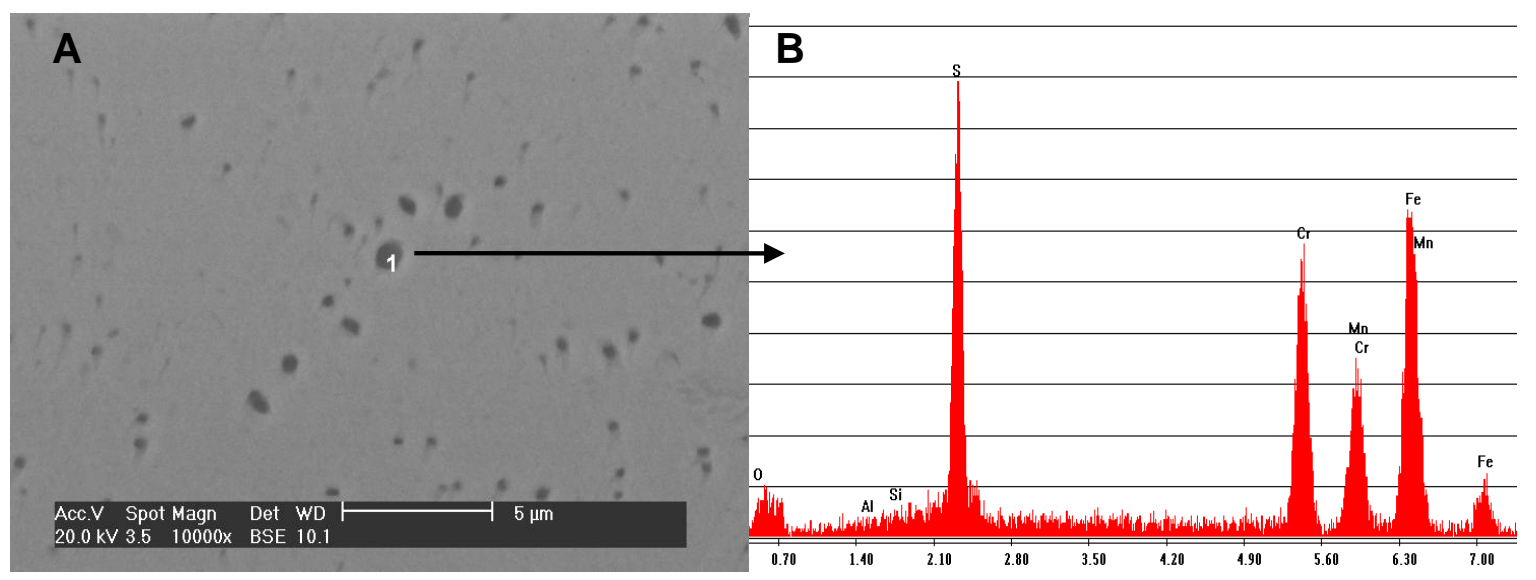

Figura 33 - Região de uma inclusão de sulfeto de manganês na liga NeoM. A) MEV; B) EDS da região indicada pela seta.

Na Figura 32, observa-se uma inclusão alongada, cujo espectro obtido por EDS indica ser um sulfeto de manganês. Na Figura 33, o espectro por EDS mostra altos teores de enxofre, cromo e manganês. Isto indica que, possivelmente, também se trata de uma inclusão de sulfeto de manganês. É importante salientar que as inclusões de sulfetos afetam, fortemente, a resistência à corrosão por pite devido à sua dissolução em baixos potenciais (WRANGLÉN, 1974). 


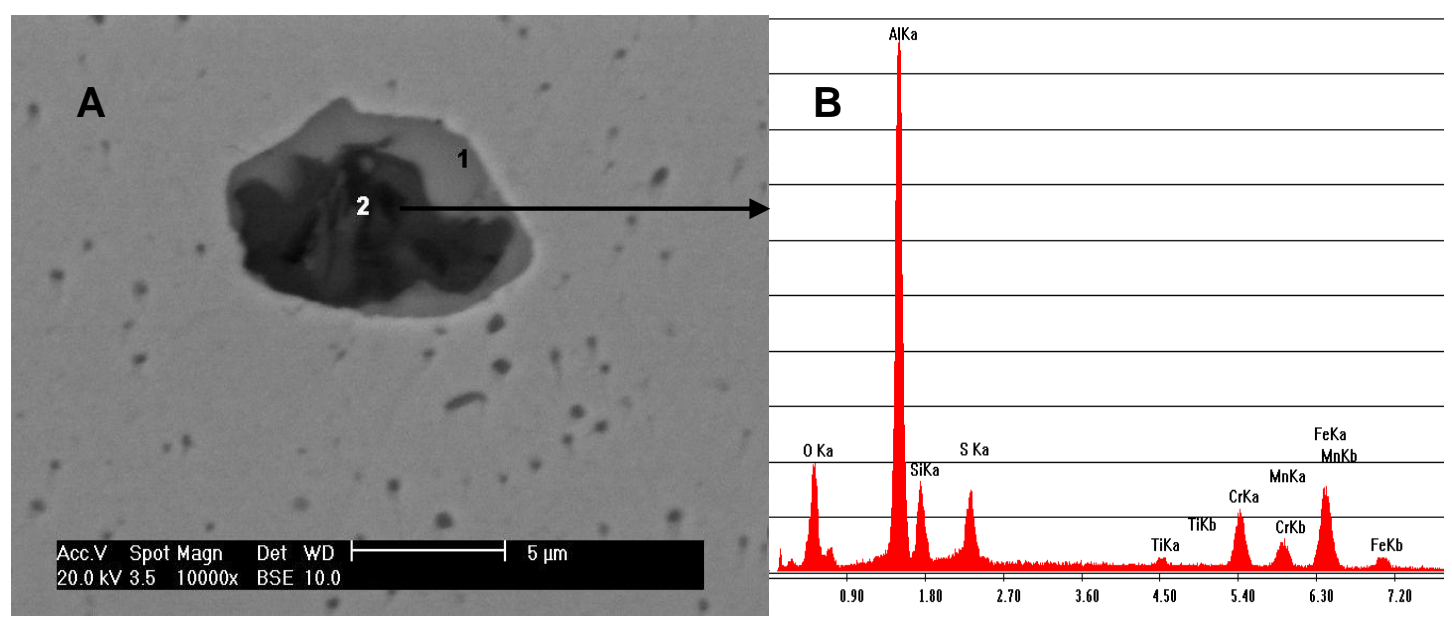

Figura 34 - Região de uma inclusão mista de sulfeto de manganês com óxido de alumínio e silício na liga NeoM. A) MEV; B) EDS da região indicada pela seta.

A Figura 34A mostra uma inclusão com diferentes tonalidades, indicando alteração significativa em sua composição química. Procedeu-se a análise semiquantitativa por EDS das duas regiões com tonalidades diferentes (pontos 1 e 2). O EDS da Figura 34B (ponto 2) mostrou elevado teor de alumínio e, em menor porcentagem, de silício, sugerindo que esta inclusão trata-se de um óxido misto de alumínio e silício. O espectro por EDS, realizado no ponto 1, foi similar ao obtido no EDS da Figura 32B, confirmando a presença de enxofre e manganês. Isto indicou que a região mais clara representa um sulfeto de manganês. É importante esclarecer que os elementos $\mathrm{S}$ e Mn são adicionados ao aço fundido, durante a fabricação para desoxidação, pois têm forte atividade com o oxigênio. As inclusões mistas são regiões de grande tendência à corrosão. A inclusão de sulfeto, que circunda a de óxido, tem boa condutividade elétrica, formando uma pilha local com a matriz metálica em torno dela. No processo de corrosão ocorre a dissolução do sulfeto, deixando uma região de fresta entre a matriz e o óxido. Dentro da fresta ocorre a redução localizada do $\mathrm{pH}$, o que dificulta a repassivação e permite a continuação do processo de corrosão, favorecendo a formação de pites.

Os precipitados de óxidos puros, em sua maioria, não são bons condutores elétricos. Portanto, não causam diretamente pilhas galvânicas eficientes. Todavia, inclusões de óxidos afetam, indiretamente, a resistência à corrosão por proporcionarem regiões de descontinuidade do filme passivo, o que diminui a resistência à corrosão do material. 


\subsubsection{Comparação da análise química com a microanálise superficial por EDS}

A análise por EDS foi feita pelo método sem padrões, que mede a superfície dos picos, a qual é proporcional à quantidade de átomos que o produziu. Esta medição é obtida pela deconvolução do espectro, que consiste em seguir os contornos dos picos por uma curva matemática, sobre a qual são efetuados os cálculos desejados. Para reduzir o erro é necessário efetuar uma correção sobre as superfícies medidas, levando-se em conta as diferentes interações físicas que intervêm no material. Utilizou-se a correção ZAF. O fator Z considera a influência do número atômico dos elementos sobre a eficácia da excitação e da detecção. $O$ fator $A$ avalia a probabilidade dos raios- $X$ serem absorvidos, antes mesmo de serem detectados. $O$ fator $F$ pondera sobre a contribuição dos raios-X emitidos por outro elemento (fluorescência secundária). Esta análise é considerada semiquantitativa, devido aos fatores que provocam variação na área do pico. Para diminuir a probabilidade de erros, todos os espectros de EDS, da Figura 35, foram obtidos com os mesmos parâmetros de operação e análise.
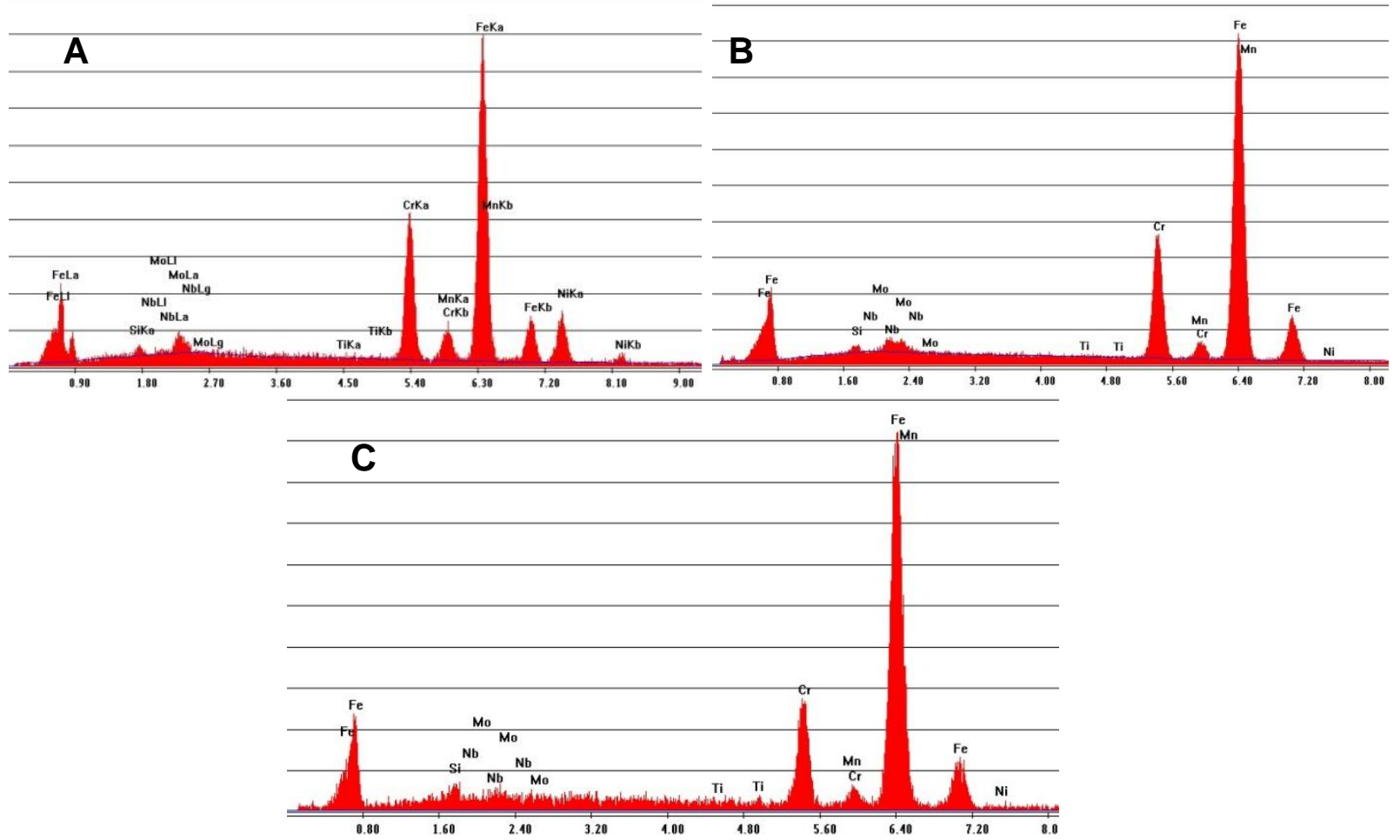

Figura 35 - Espectros de EDS para o metal base. A) Aço ISO 5832-1 B) Aço AISI 444 C) Aço NeoM

Os elementos, cujas leituras são em bandas de maior energia (camada $\mathrm{K}$ ), costumam apresentar um erro menor, do que os elementos de bandas de 
baixa energia (camada $L$ ), onde as perdas por absorção na amostra são grandes. O cromo, o níquel e o silício foram obtidos com espectros dos fótons emitidos pela camada $\mathrm{K}$, enquanto o molibdênio pela camada $\mathrm{L}$.

Pela deconvolução dos espectros da Figura 35 e posterior correção das superfícies dos picos pelo método ZAF, obtiveram-se os resultados das análises semiquantitativas (Tabela 10). Somente os elementos com porcentagem em massa superior a $0,5 \%$, na análise química, foram considerados. Os valores e os respectivos desvios foram calculados pela média de 3 leituras, em diferentes regiões. Os resultados das análises químicas foram retirados das tabelas anteriormente apresentadas (Tabelas 7, 8 e 9).

Tabela 10 - Análise semiquantitativa e análise química dos principais elementos de ligas dos aços ISO 5832-1, AISI 444 e NeoM (\% em massa).

\begin{tabular}{lcccccccc}
\hline & \multicolumn{2}{c}{ Cr } & \multicolumn{2}{c}{ Mo } & \multicolumn{2}{c}{ Ni } & \multicolumn{2}{c}{ Si } \\
\hline & EDS & Anal. & EDS & Anal. & EDS & Anal. & EDS & Anal. \\
\hline AISI 444 & $17,5 \pm 0,1$ & 16,27 & $1,5 \pm 0,3$ & 1,99 & $0,9 \pm 0,2$ & 0,50 & $0,9 \pm 0,2$ & 0,58 \\
NeoM & $12,4 \pm 0,3$ & 13,2 & $0,3 \pm 0,2$ & 0,34 & $0,8 \pm 0,4$ & 3,11 & $1,2 \pm 0,2$ & 1,10 \\
ISO 5832-117,7 00,1 & 18,32 & $3,3 \pm 0,1$ & 2,59 & $13,0 \pm 0,3$ & 14,33 & $0,7 \pm 0,2$ & 0,37 \\
\hline
\end{tabular}

Os resultados da análise semiquantitativa por EDS ficaram próximos aos obtidos pela análise química, exceto o teor de níquel para o NeoM, que amostrou valores distintos entre as duas análises. Esta comparação serviu para validar os espectros de EDS.

Na Figura 36, tem-se o gráfico comparativo da composição química, obtida por métodos de análise química, dos principais elementos de ligas dos aços ISO 5832-1, AISI 444 e NeoM.

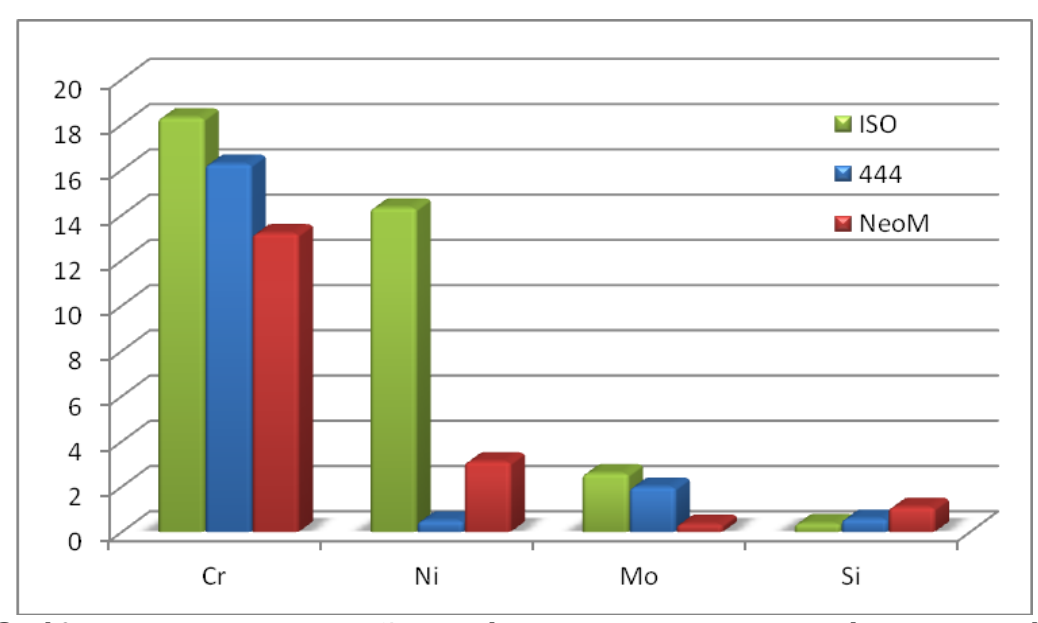

Figura 36 - Gráfico da composição química obtida por métodos químicos $(\%$ em massa) dos principais elementos de liga dos aços ISO 5832-1, AISI 444 e NeoM. 
Para discutir os resultados da Figura 36 é importante explicar os efeitos dos principais elementos de liga nas propriedades físico-químicas dos materiais estudados (Tabela 11) segundo MODENESI (2001), FARIA (2000), PADILHA (1994), FOLKHARD (1988), MORGENFELD (1983) e BRUCE et al.(2002).

Tabela 11 - Efeito dos principais elementos de liga nas propriedades físicoquímicas dos materiais estudados.

\begin{tabular}{|c|l|}
\hline Cr & $\begin{array}{l}\text { É o elemento de liga fundamental dos aços inoxidáveis, sendo adicionado } \\
\text { em teores mínimos de 12\%. Sua função é a formação de uma camada } \\
\text { passiva, que protege o aço contra o ataque de agentes agressivos. } \\
\text { Quanto maior o teor de cromo, maior a resistência à corrosão. }\end{array}$ \\
\hline $\mathbf{N i}$ & $\begin{array}{l}\text { É um elemento austenitizante. Aumenta a resistência à corrosão em } \\
\text { meios não oxidantes e, em pequenas quantidades, melhora a tenacidade } \\
\text { e a solubilidade de ligas ferríticas e martensíticas. }\end{array}$ \\
\hline Mo & $\begin{array}{l}\text { É um formador de ferrita e carbetos. Combinado com o cromo é efetivo na } \\
\text { estabilização da camada passiva em meios contendo cloretos. Melhora a } \\
\text { resistência à corrosão generalizada em meios oxidantes. Diminui a } \\
\text { suscetibilidade à corrosão por pite em todos os meios. }\end{array}$ \\
\hline \multirow{5}{*}{$\mathbf{S i}$} & $\begin{array}{l}\text { É usado como desoxidante do aço. Favorece as propriedades mecânicas } \\
\text { (limite de escoamento e de resistência) e a resistência à corrosão, porém } \\
\text { reduz a soldabilidade. É um elemento estabilizador da ferrita. Reduz a } \\
\text { formação de carbonetos, auxiliando na decomposição da cementita } \\
\left(F e_{3} \mathrm{C}\right) \text { em ferrita. }\end{array}$ \\
\hline
\end{tabular}

Comparando as composições químicas dos materiais (Figura 36), observou-se que a quantidade de níquel está condizente com a composição de um aço austenítico, para o ISO, e ferrítico, para o 444 e o NeoM. Mesmo assim, o teor de níquel do NeoM está muito acima do esperado ( $\leq 1 \%$ segunda a norma JIS). Isto poderia promover a formação de fase austenítica, o que, provavelmente, não ocorre devido à presença de silício. $\mathrm{O}$ aço NeoM possui teores de $\mathrm{Cr}$ e Mo inferiores ao dos aços ISO e AISI 444. Segundo BRANDIS (1985), o Mo tem maior influência (3,3 vezes) na resistência à corrosão localizada de um material que o Cr. Considerando os efeitos dos elementos na liga (Tabela 11), pode-se supor que o NeoM possui um filme passivo menos protetor contra a corrosão.

HANNINEN et al. (2001) propuseram uma fórmula que relacionam a resistência à corrosão por pite (PRE $=$ Pitting Resistance Equivalent) com as concentrações de nitrogênio, cromo e molibdênio. As equações para cálculo do PRE são dadas a seguir:

$\mathrm{PRE}=\% \mathrm{Cr}+3,3 \% \mathrm{Mo}$, para aços inoxidáveis ferríticos. 
PRE $=\% \mathrm{Cr}+3,3 \% \mathrm{Mo}+16(30) \% \mathrm{~N}$, (30 para aços inoxidáveis austeníticos e 16 para duplex).

Os valores do PRE dos materiais estudados foram calculados com base nos resultados de análise química e são apresentados na Figura 37.

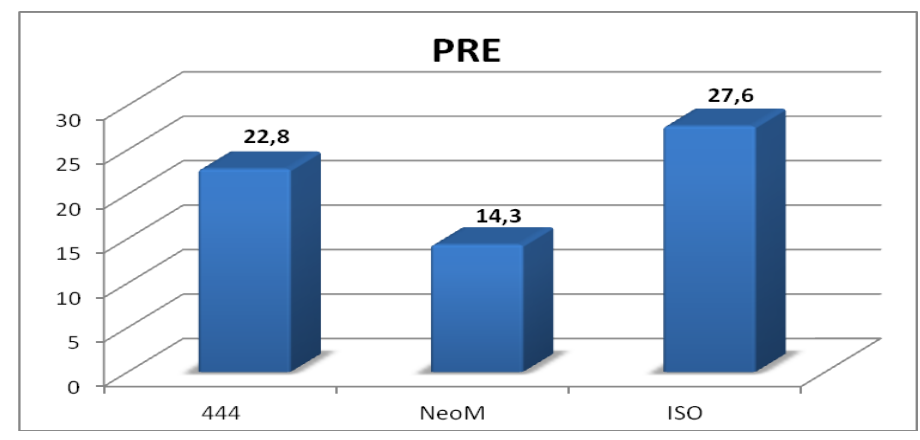

Figura 37 - Valores do PRE dos aços ISO, NeoM e 444 calculados com base nos resultados de composição obtidos por análise química.

O PRE fornece uma estimativa da resistência à corrosão localizada, baseada apenas em poucos elementos de liga ( $\mathrm{Cr}, \mathrm{Mo}, \mathrm{N})$. Outros elementos, não incluídos na equação, podem influenciar negativamente neste tipo de processo, como, por exemplo, o enxofre. Este forma inclusões de sulfetos, que podem atuar como pontos preferenciais para formação de pites (BOMBARA e CAVALLINI, 1977).

Para TERADA (2006), o PRE deve ser avaliado com cautela, pois não considera a microestrutura do material, a qual pode influenciar, positivamente ou negativamente, na resistência a corrosão. Com base nos resultados da Figura 37, o menor índice, obtido pelo aço NeoM, sugere uma menor resistência à corrosão por pite, em comparação aos demais aços.

\subsection{Citotoxicidade in vitro}

A Figura 38 mostra os resultados do ensaio de citotoxicidade in vitro para o aço inoxidável AISI 444, obtidos pelo método de incorporação do vermelho neutro. 


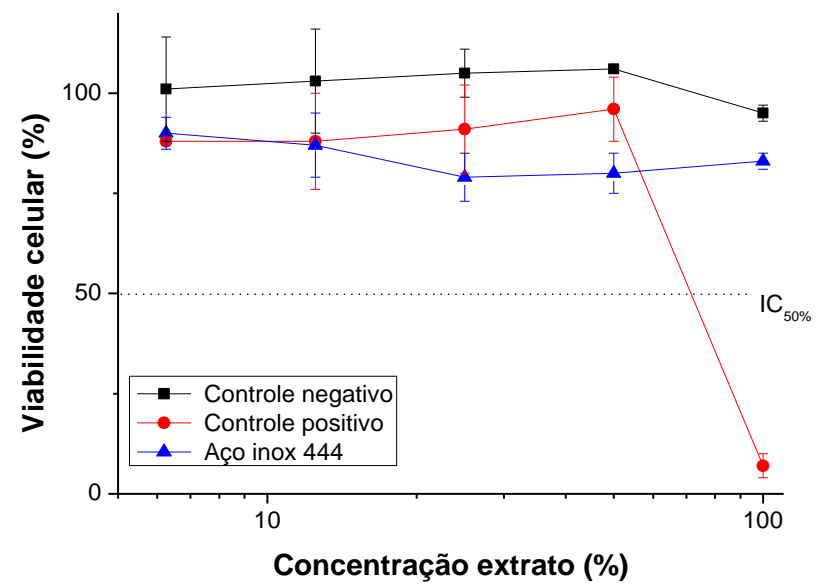

Figura 38 - Curvas de viabilidade celular obtidas pelo método de análise colorimétrica.

Pelo método de incorporação celular do corante supravital vermelhoneutro, observou-se que o aço inoxidável AISI 444 apresentou um comportamento similar ao controle negativo, ou seja, sem indicação de citotoxicidade. Isto foi indicado pela curva de viabilidade celular acima do índice $\mathrm{IC}_{50 \%}$. Este resultado está de acordo com trabalho publicado por ROGERO et al. (2006), que utilizaram esta mesma metodologia para o mesmo aço.

Os resultados obtidos por MALHEIRO et al. (2011) também apoiam os do presente trabalho. Os autores observaram que as células osteoblásticas, cultivadas sobre o aço AISI 444, exibiram um grau de aderência, crescimento e osteogenicidade muito similar ao do grupo controle. Pela atividade celular dos monócitos, concluiram que o aço AISI 444 não apresenta efeito citotóxico ou resposta inflamatória significativa.

\subsection{Força de retenção magnética}

A força necessária para provocar a separação, entre o imã e as amostras avaliadas, é mostrada na Figura 39.

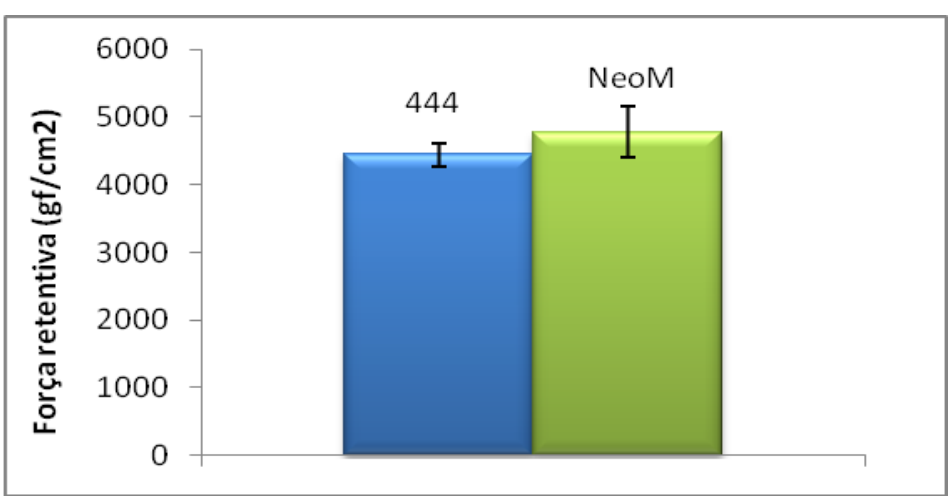

Figura 39 - Resultados da força de retenção magnética para os aços 444 e NeoM. 
Comparando-se o material experimental (444) com o grupo controle (NeoM), os resultados foram estatisticamente iguais. A força de retenção magnética está diretamente relacionada à saturação de magnetização que, por sua vez, depende diretamente da quantidade de ferro e elementos de liga, os quais evitam a formação de fase austenítica (não magnética). Estes dois materiais possuem porcentagens de ferro similares (NeoM: 81,65\% e 444: 77,80\%) e uma estrutura cristalina predominantemente ferrítica (magnética) em temperatura ambiente. Por estes motivos, a saturação de magnetização foi equivalente.

\subsection{Potencial de circuito aberto em condição naturalmente aerada}

A Figura 40 apresenta as curvas de variação do potencial de circuito aberto, em função do tempo de imersão (solução de PBS naturalmente aerada a $37^{\circ} \mathrm{C}$ ), para os aços inoxidáveis ISO, 444, 444S e NeoM. O período total de imersão foi de 48 horas.

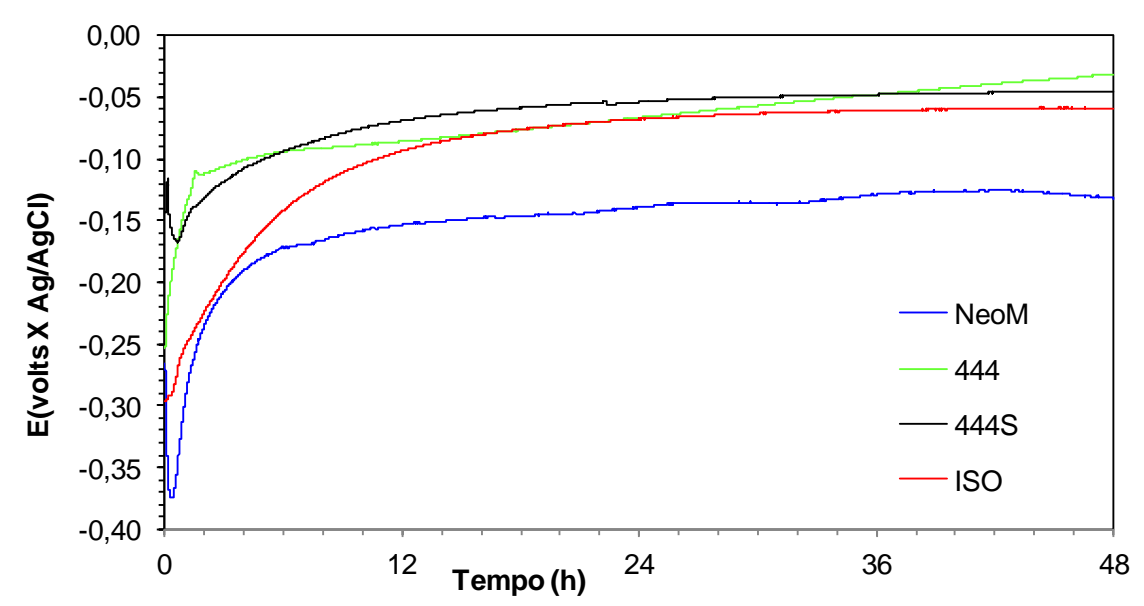

Figura 40 - Variação do potencial de circuito aberto ao longo do tempo de imersão de 48 horas, em solução PBS naturalmente aerada e a $37^{\circ} \mathrm{C}$, para os aços NeoM, 444, 444S e ISO.

Analisando a Figura 40, todos os materiais mostraram uma queda de potencial inicial, seguida por uma tendência de aumento do mesmo com o tempo de imersão. Após cerca de 10 horas de imersão, todas as ligas testadas atingiram a estabilização, sendo observada pouca variação após este período. A queda inicial de potencial foi causada pela dissolução parcial do filme passivo, provocada por íons agressivos presentes no eletrólito. Como o meio não foi suficientemente agressivo ocorreu a reparação do filme e, no decorrer do tempo, o aumento da espessura deste. Isto gerou valores mais positivos de potencial. Os potenciais de circuito aberto, após a estabilização, são mostrados na Tabela 12. 
Tabela 12 - Potenciais de circuito aberto dos aços NeoM, 444, 444S e ISO, após 48 horas de imersão em solução PBS.

\begin{tabular}{cc}
\hline AçOS & $\mathrm{E}\left(\mathrm{mV}_{\mathrm{Ag} / \mathrm{AgCl}}\right)$ \\
\hline 444 & $-32( \pm 15)$ \\
$444 S$ & $-45( \pm 10)$ \\
ISO & $-58( \pm 10)$ \\
NeoM & $-131( \pm 20)$ \\
\hline
\end{tabular}

Todos os materiais estabilizaram em potenciais superiores a -300 $\mathrm{mV}_{\mathrm{ECS}}$, o que é característico de materiais ferrosos passivos em meios aquosos aerados. Os aços ISO, 444 e 444S estabilizaram em potenciais mais elevados, sendo que o 444 obteve o potencial mais nobre, seguido pelo $444 \mathrm{~S}$ e pelo ISO. $\mathrm{O}$ aço NeoM mostrou um potencial de estabilização bem inferior aos demais, o que sugere a presença de um óxido superficial menos protetor.

\subsection{Curvas de polarização anódica potenciodinâmica cíclica em condição naturalmente aerada}

As curvas de polarização possibilitam a determinação de parâmetros importantes no estudo da corrosão de um metal. Neste método, o potencial do eletrodo de trabalho (material em estudo) é variado, constantemente, pela aplicação de uma sobretensão em relação ao potencial de repouso. A densidade de corrente, resultante da variação do potencial, é medida ao longo da polarização. Os resultados permitem avaliar a taxa de corrosão, a resistência da camada passiva, as regiões de ativação e passivação e, até mesmo, a presença de precipitados na amostra (WOLYNEC, 2003).

As curvas de polarização mostraram reprodutibilidade, sendo as curvas presentes na Figura 41 as representativas destes resultados. 

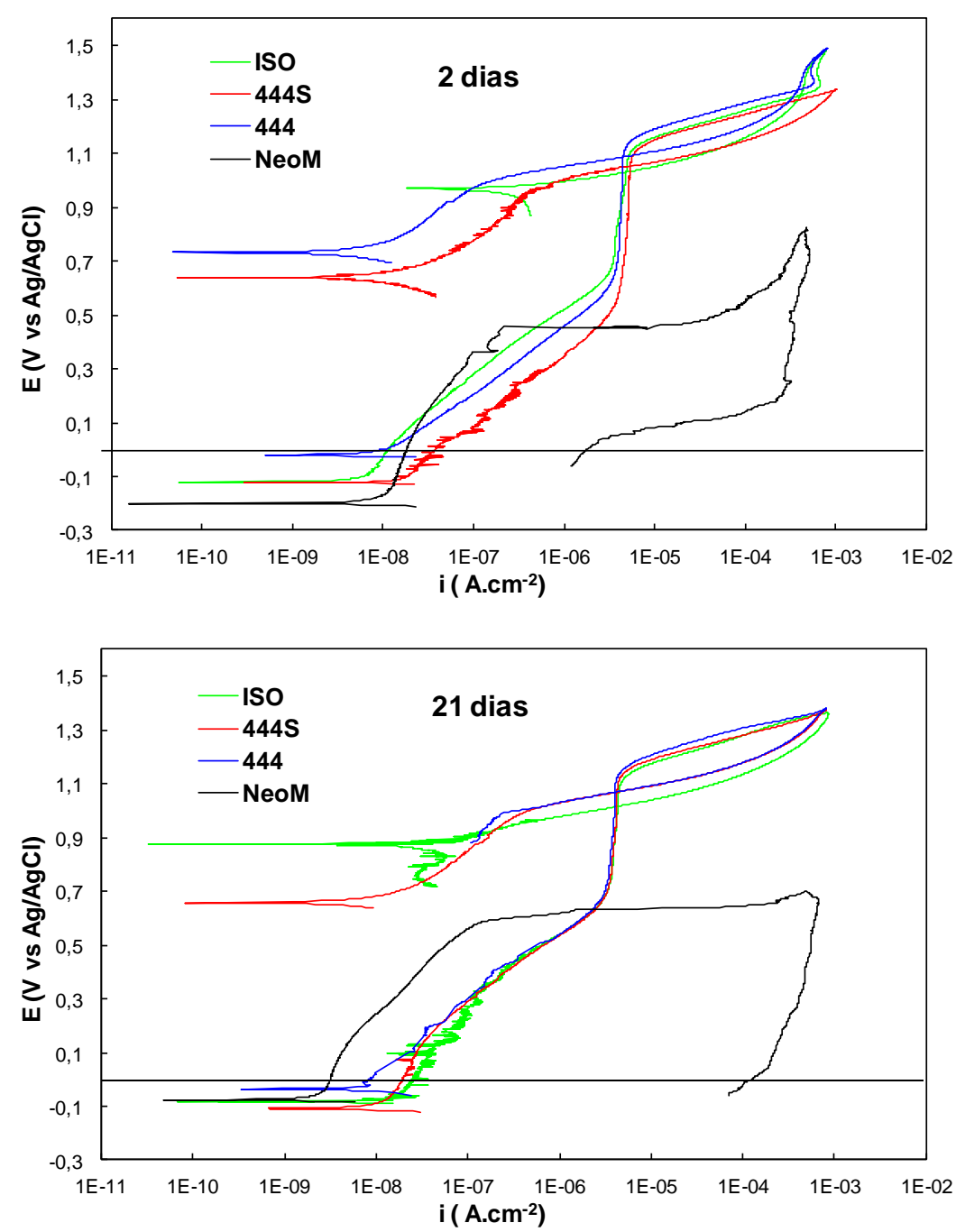

Figura 41 - Curvas de polarização anódica potenciodinâmica cíclica, após 2 e 21 dias de imersão em solução PBS, naturalmente aerada a $37^{\circ} \mathrm{C}$, para os aços NeoM, 444, 444S e ISO.

A Figura 41 mostra as curvas de polarização anódica potenciodinâmica cíclica para os aços ISO, 444, 444S e NeoM, obtidas após 2 e 21 dias de imersão em solução PBS. Por ser um teste destrutivo, foram utilizados eletrodos diferentes para 2 e 21 dias. As densidades de corrente, no potencial de corrosão, dos aços NeoM, 444, 444S e ISO foram da ordem de $10^{-7}$ A.cm ${ }^{-2}$ a $10^{-6}$ A.cm ${ }^{-2}$, típicas de materiais em estado passivo. O comportamento eletroquímico exibido pelo aço NeoM, no ensaio de polarização anódica cíclica, foi típico de materiais que apresentam potencial crítico de pite $\left(E_{c}\right)$ bem definido. Este parâmetro determina o potencial máximo, acima do qual ocorre a quebra do filme passivo, ocasionando a propagação de um ou mais pites de corrosão. Como consequência, observa-se um aumento abrupto da densidade de corrente. Outro aspecto que confirma a ocorrência de corrosão por pite é a formação de uma curva de histerese, após a 
reversão no sentido de varredura (inversão do sentido de polarização). A região da histerese caracteriza-se pelo crescimento dos pites que não conseguem repassivar. Quanto maior esta área, menor a tendência à repassivação. O potencial de proteção $\left(E_{p}\right)$ é definido quando a curva no sentido reverso de varredura cruza a do sentido direto, abaixo do qual os pites são repassivados (WOLYNEC, 2003). As amostras do aço NeoM apresentaram pites com distribuição generalizada, atingindo diâmetros de $0,1 \mathrm{~mm}$ até $0,3 \mathrm{~mm}$ (Figura 42). Devido ao tamanho dos pites e a baixa capacidade de recuperação do filme passivo observou-se que o potencial de repassivação não foi atingido até o limite estabelecido na varredura reversa.

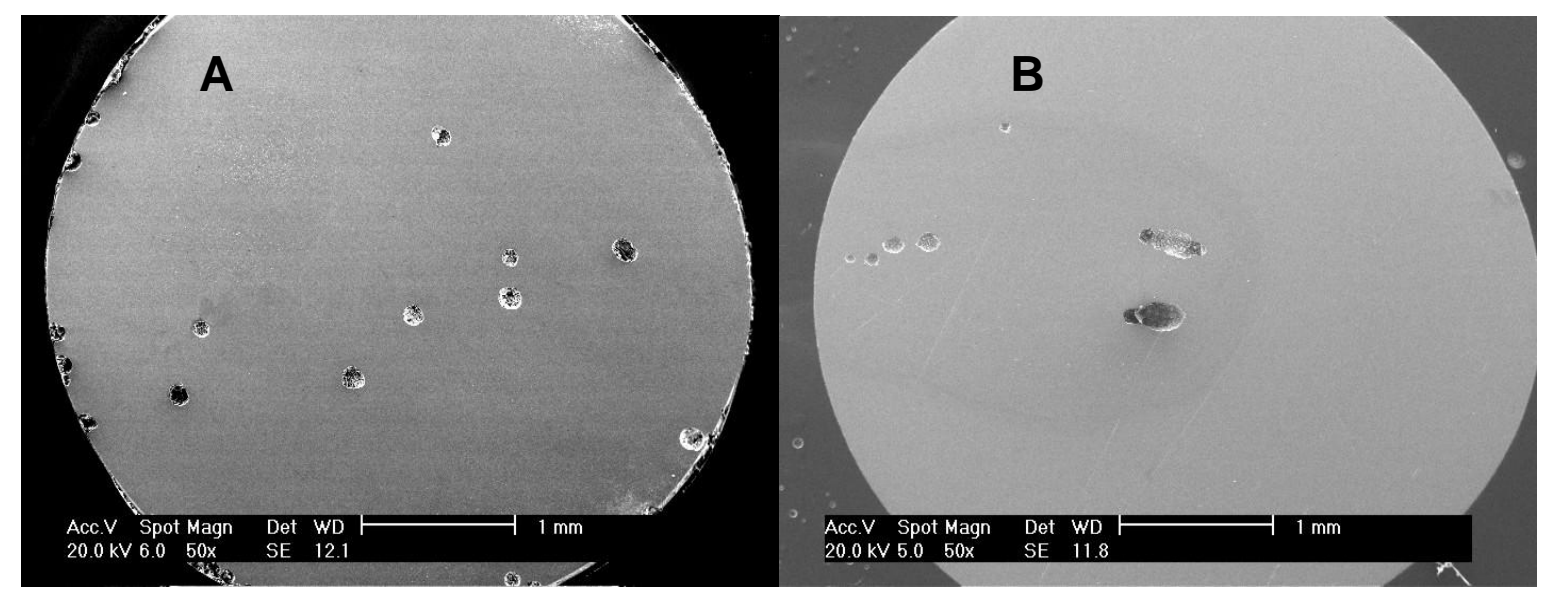

Figura 42 - Superfície do aço NeoM, após polarização anódica em solução PBS, naturalmente aerada a $37^{\circ} \mathrm{C}$. A) 2 dias de imersão B) 21 dias de imersão.

Para o aço NeoM, o potencial crítico de pite $\left(E_{c}\right)$ foi de aproximadamente $500 \mathrm{mV}_{\mathrm{Ag} / \mathrm{AgCl}}$, para 2 dias de imersão, e cerca de $550 \mathrm{mV}_{\mathrm{Ag} / \mathrm{AgCl}}$ para 21 dias. O maior potencial de pite e a maior histerese (Figura 41), obtidos para períodos mais longos de imersão, sugerem que o filme passivo tornou-se mais espesso e resistente no decorrer do ensaio. Porém, nas regiões onde ocorreu o ínicio da corrosão localizada há maior dificuldade para repassivar, uma vez que os pontos de quebra são em menor número (Figura 42B) e, portanto, a corrente anódica é menos distribuída.

Na Figura 43A é mostrado um pite no aço NeoM ainda nos estágios iniciais de formação. Em um maior aumento (Figura 43B), observou-se a presença de um precipitado dentro do pite, cujo espectro obtido por EDS mostrou picos de $\mathrm{Mn}$ e $\mathrm{S}$ (Figura 44). A presença desses precipitados, já observados anteriormente na Figura 32, e os menores teores de $\mathrm{Cr}$ e Mo podem justificar o 
desempenho inferior do aço NeoM, quando comparado com os aços AISI 444 e ISO 5832-1.

A menor resistência a corrosão localizada do NeoM, observada pelas curvas de polarização anódicas, está de acordo com o menor valor de PRE obtido na Figura 37.

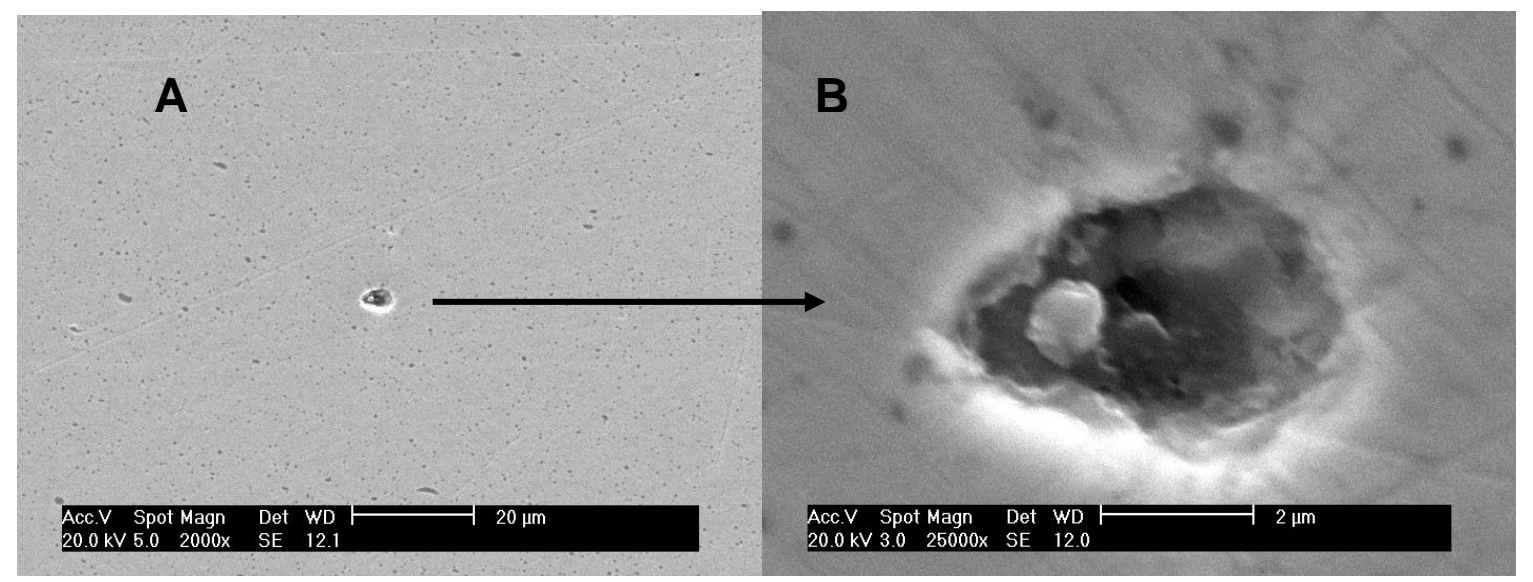

Figura 43 - Aço NeoM, após polarização anódica em solução PBS, naturalmente aerada a $37^{\circ} \mathrm{C}$. A) Processo de formação de pite em sua fase inicial. B) Maior aumento evidenciando a presença de um precipitado.

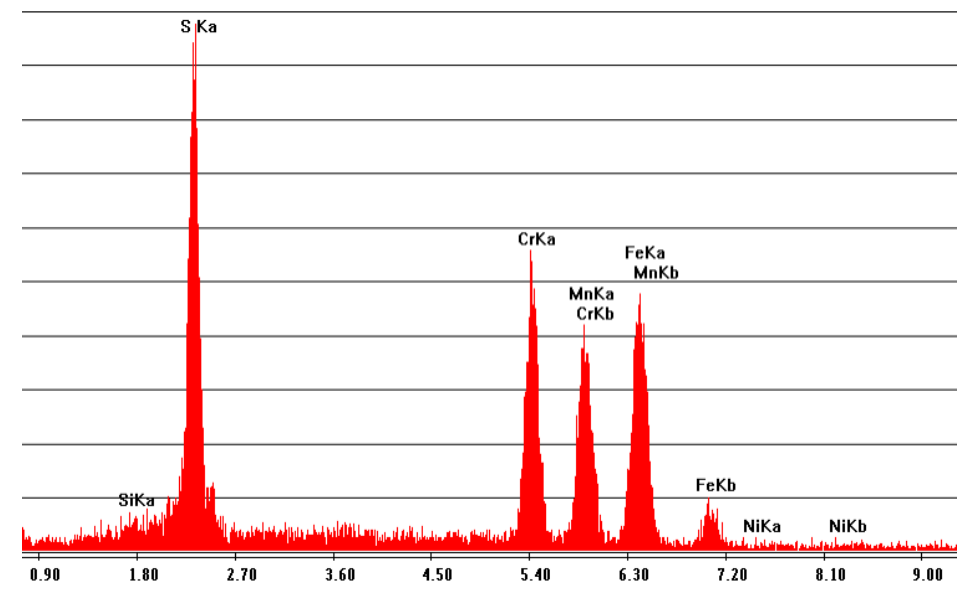

Figura 44 - Espectro de EDS da região do precipitado mostrado na Figura 43.

As curvas de polarização para os aços 444, 444S e ISO (Figura 41), nos dois tempos de imersão, mostraram que esses materiais têm resistência à corrosão e densidade de corrente anódica similares. As áreas de histerese e os potenciais de proteção (1000 mV Ag/AgCl em 2 dias e $900 \mathrm{mV}_{\text {Ag/AgCl }}$ em 21 dias) também foram equivalentes. $O$ aumento na densidade de corrente ocorreu em potenciais próximos a $1100 \mathrm{mV}_{\mathrm{Ag} / \mathrm{AgCl}}$, sendo que nesta faixa de potencial pode estar ocorrendo a reação de evolução de oxigênio. Para identificar se o aumento 
de corrente foi devido à formação de pites, as amostras polarizadas foram observados por MEV.

$\mathrm{Na}$ Figura 45 são mostradas as micrografias da superfície dos aços AISI 444 e 444S, polarizadas anodicamente, após 21 dias de imersão em PBS.

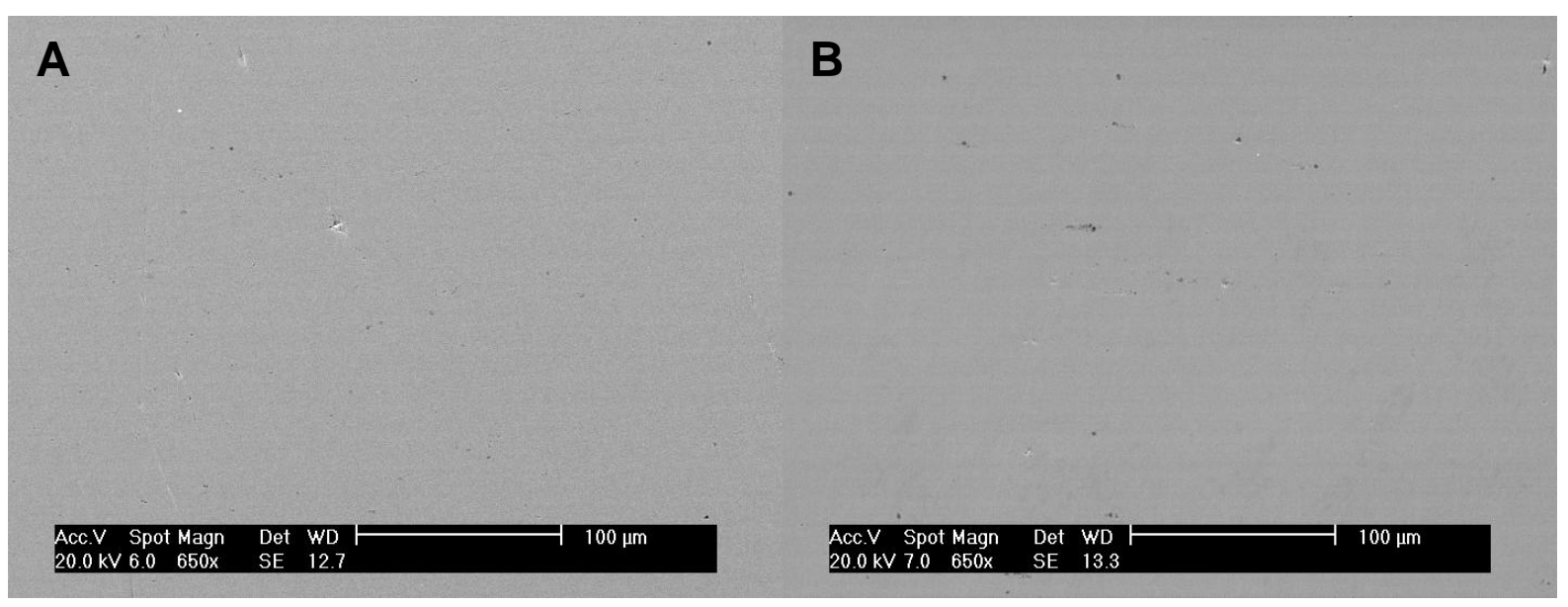

Figura 45 - Micrografias obtidas por MEV da superfície do aço AISI 444, polarizado anodicamente pela técnica potenciodinâmica cíclica, após 21 dias de imersão em solução PBS a $37^{\circ}$ C. A) Como recebido (444); B) Solubilizado (444S).

$\mathrm{Na}$ Figura 45 não foram observados sinais de corrosão por pite. $\mathrm{O}$ mesmo ocorreu para amostras do aço AISI 444 e 444S, polarizadas após 2 dias de imersão. A presença de pequenos pontos nas micrografias deixou dúvidas quanto à presença de pites. Pela imagem da Figura 46A, com maior aumento, confirmou-se que não ocorreu corrosão localizada. Os pontos foram identificados como precipitados da liga, conforme análise por EDS (Figura 46B). Desta forma, pela observação das micrografias apresentadas na Figura 45A e B, pode-se supor que o aumento da densidade de corrente, nas amostras de 444 e 444S, foi provocado pela reação de evolução de oxigênio.

Os precipitados encontrados no aço AISI 444 são consequência da adição proposital de elementos estabilizantes ( $\mathrm{Ti}$ e $\mathrm{Nb}$ ) que visam controlar os efeitos danosos dos elementos intersticiais (BROWN ET al, 1983). Desta forma, evita-se a precipitação de carbonetos de cromo, o que diminui o risco de corrosão intergranular. 


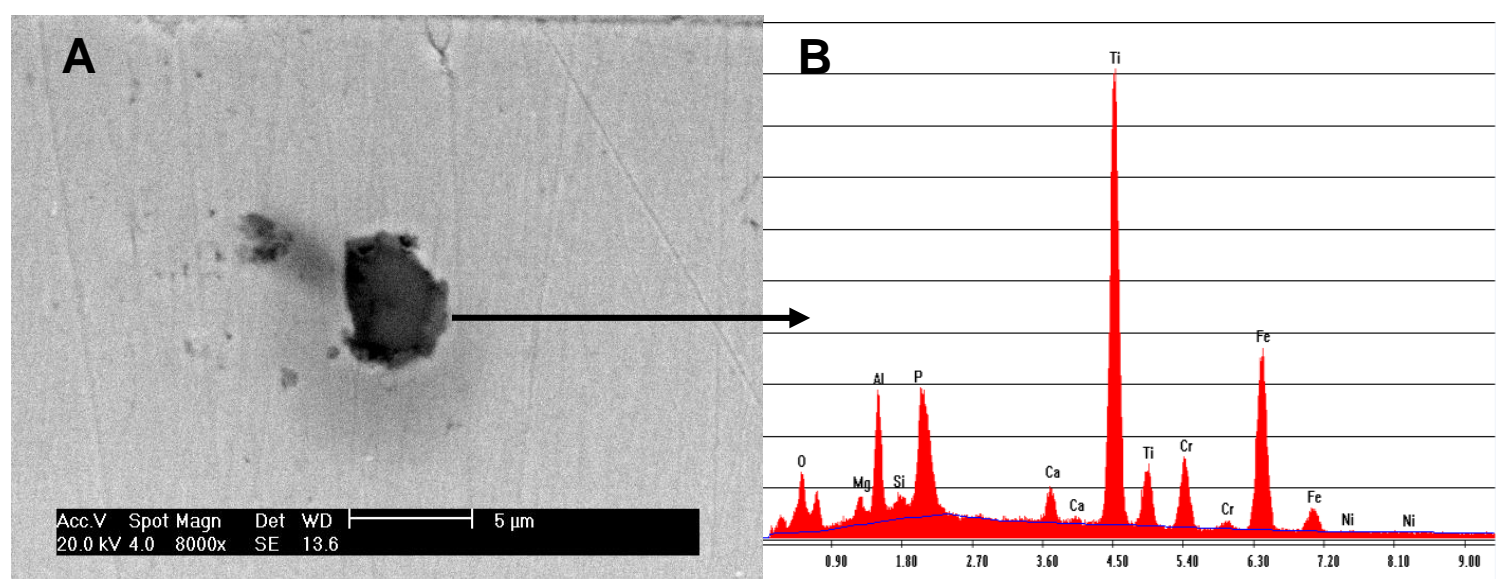

Figura 46 - Micrografia por MEV de um precipitado do aço 444 polarizado anodicamente, após 21 dias de imersão em solução PBS a $37^{\circ} \mathrm{C}$. A) Região de precipitado; B) Espectro por EDS da região indicada.

A Figura 47 mostra as micrografias do aço ISO 5832-1 polarizado anodicamente, após 21 dias de imersão em solução PBS.

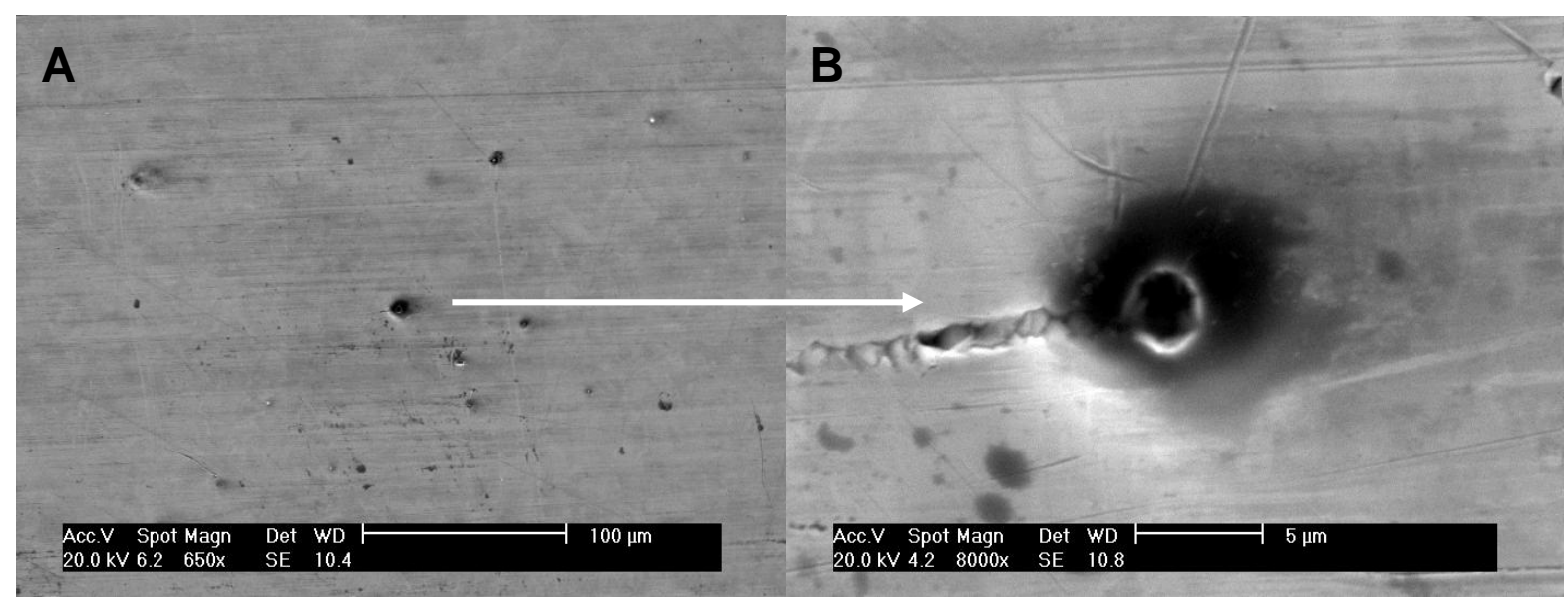

Figura 47 - Micrografias obtidas por MEV do aço ISO 5832-1, polarizado anodicamente pela técnica potenciodinâmica, após 21 dias de imersão em solução PBS a $37^{\circ} \mathrm{C}$. A) Visão geral; B) Maior aumento da área indicada.

Na micrografia da Figura 47A, observou-se uma similaridade superficial com a do aço ISO antes da polarização (Figura 19). Em um maior aumento, foi localizada uma área de possível arrancamento de precipitado, devido ao polimento, o que é sugerido pela formação de uma imagem semelhante a um "cometa" (Figura 47B). Esta microcavidade formada favorece 0 ataque preferencial, podendo levar à nucleação de pites. O diâmetro reduzido do mesmo (apenas $3 \mu \mathrm{m}$ ) é devido à capacidade de repassivação do aço ISO, o qual impediu a propagação do processo de corrosão localizada. 
5.6 Ensaios de espectroscopia de impedância eletroquímica (EIE) em condição naturalmente aerada

A técnica de EIE é muito utilizada em diversos estudos de corrosão, por possibilitar a separação de diferentes processos eletroquímicos que ocorrem com cinéticas distintas (MANSFELD e SHIH, 1988).

5.6.1 Aço inoxidável austenítico ISO 5832-1

$\mathrm{Na}$ Figura 48, são mostrados os diagramas de impedância do aço inoxidável ISO 5832-1, após 2, 7, 14 e 21 dias de imersão, em solução PBS naturalmente aerada e $37^{\circ} \mathrm{C}$.
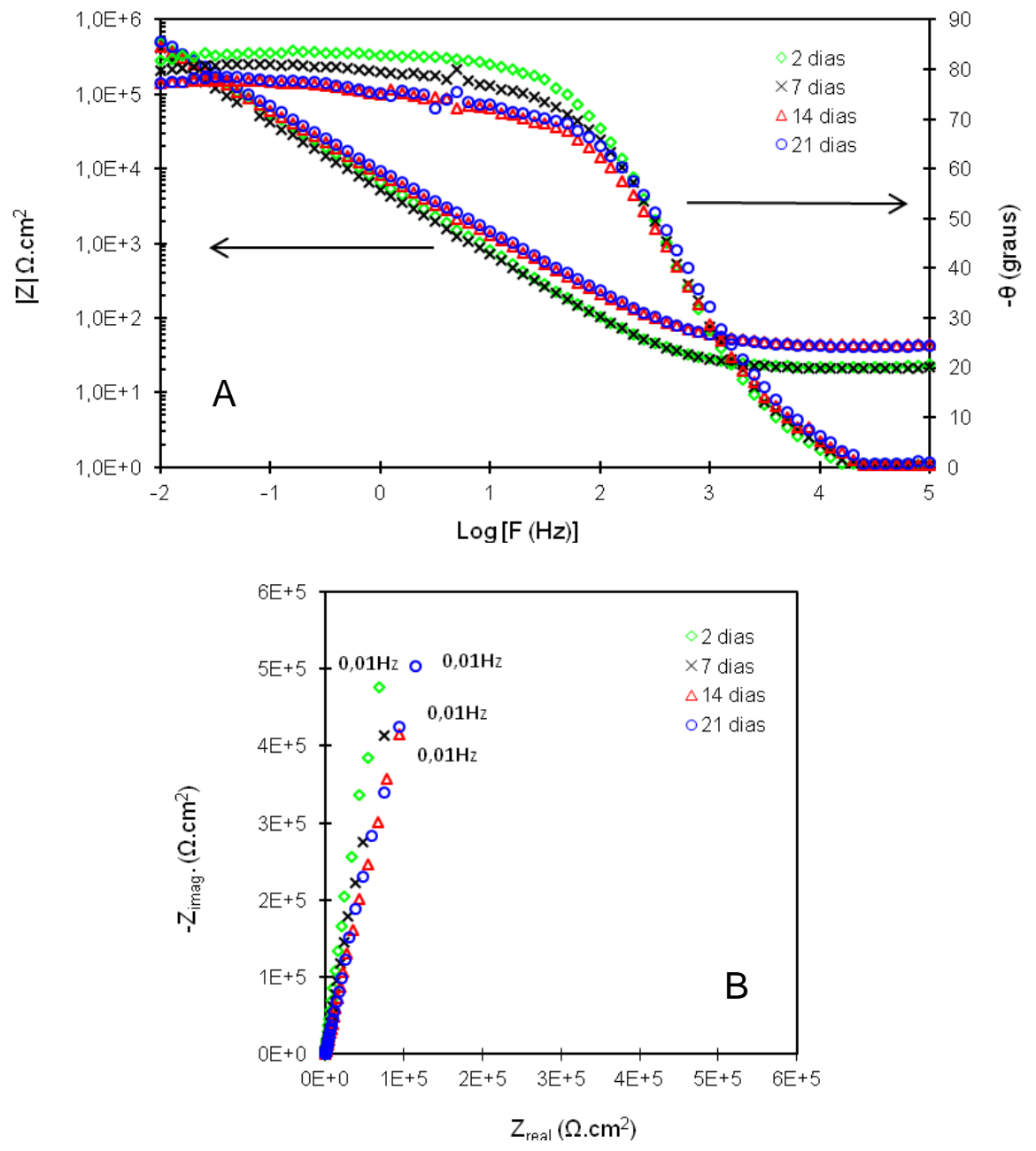

Figura 48 - Diagramas de impedância do aço ISO 5832-1 em solução PBS, naturalmente aerada e a $37 \stackrel{\circ}{\mathrm{C}}$. A) Diagramas de Bode. B) Nyquist. 
Os diagramas de Bode, mostrados na Figura 48A, revelaram que o aço ISO apresentou comportamento capacitivo, com ângulos de fase entre $-70^{\circ}$ e $-80^{\circ}$ nas regiões de baixa frequência, para todos os períodos de imersão. Este comportamento é típico de metais passivos, como observado por PÉREZ et al. (2002) para o aço 316L. Os diagramas apresentaram variação mínima, em função do período de imersão, mostrando a estabilidade da superfície. Após o segundo dia, teve-se uma redução no valor do ângulo de fase em baixas frequências, que foi de $-80^{\circ}$ para valores próximos a $-70^{\circ}$. Mesmo com esta redução, o aço ainda estava em estado passivo. Entre 2 e 21 dias ocorreu ligeiro aumento de impedância, provavelmente pelo espessamento do filme passivo. A presença de um platô, na região de média a baixa frequência, foi possivelmente ocasionada pela sobreposição das constantes de tempo. Os valores do módulo de impedância tiveram pequeno aumento na região de altas e médias frequências, após 7 dias de imersão. Em baixas frequências, mantiveram-se praticamente constantes durante todos os períodos, com valores da ordem de $10^{5} \Omega . \mathrm{cm}^{2}$ a 0,01 $\mathrm{Hz}$, os quais são condizentes com a presença de um filme passivo.

Os diagramas de Nyquist (Figura 48B) foram caracterizados por um início de arco capacitivo, com elevadas impedâncias nas baixas frequências (ordem de $10^{5} \Omega . \mathrm{cm}^{2}$ a $0,01 \mathrm{~Hz}$ ) em todos os períodos de imersão. Entre 2 e 14 dias, observou-se uma pequena redução da impedância, e entre 14 e 21 dias ocorreu um pequeno aumento. Os resultados indicaram, portanto, a presença de processos dinâmicos de ataque e recuperação do filme passivo, ocasionados pelo meio.

\subsubsection{Aço inoxidável ferrítico AISI 444}

$\mathrm{Na}$ Figura 49, são mostrados os diagramas de impedância do aço inoxidável AISI 444, após 2, 7, 14 e 21 dias de imersão, em solução PBS naturalmente aerada a $37^{\circ} \mathrm{C}$. 

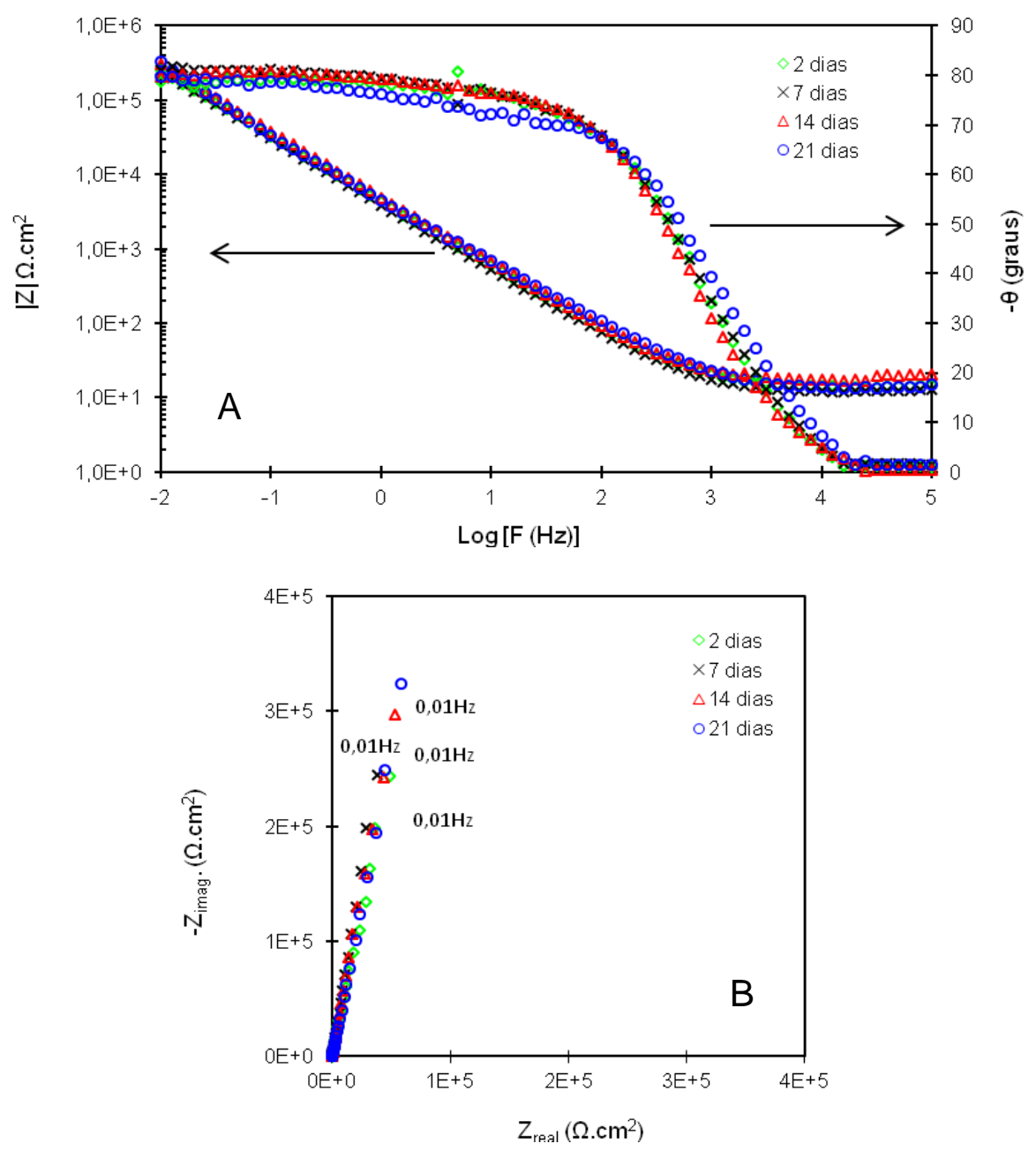

Figura 49 - Diagramas de impedância do aço AISI 444 (como recebido) em solução PBS, naturalmente aerada e a $37^{\circ} \mathrm{C}$. A) Diagramas de Bode. B) Nyquist.

Os diagramas de Bode, mostrados na Figura 49A, apresentam ângulos de fase ao redor de $-80^{\circ}$, nas regiões de baixa frequência, para todos os períodos de imersão, sendo que ocorreu uma pequena redução destes valores após 21 dias de ensaio. Não se observou variação nos diagramas em função do tempo, mostrando alta estabilidade do sistema estudado no meio de ensaio. Todos apresentaram um ombro próximo a $100 \mathrm{~Hz}$, seguido por um patamar até as baixas frequências, provavelmente devido à sobreposição das constantes de tempo. Avaliando-se os valores do módulo de Z, a impedância do aço AISI 444 não variou significativamente ao longo do período de imersão estudado, o que indica a estabilidade do sistema, apesar de pequenas modificações no filme passivo, devido à interação com o meio. Os valores do módulo de impedância da ordem de $10^{5} \Omega . \mathrm{cm}^{2}$, em $0,01 \mathrm{~Hz}$, são explicados pela presença da camada passiva. 
Os diagramas de Nyquist (Figura 49B) mostraram comportamento altamente capacitivo. Houve um pequeno aumento da impedância entre 2 e 21 dias de ensaio, provavelmente associado ao crescimento do óxido superficial, o qual resultou no aumento da resistência do filme passivo.

$\mathrm{Na}$ Figura 50 observam-se os diagramas de impedância do aço AISI 444 solubilizado (444S), após 2, 7, 14 e 21 dias de imersão, em solução PBS naturalmente aerada e a $37^{\circ} \mathrm{C}$.

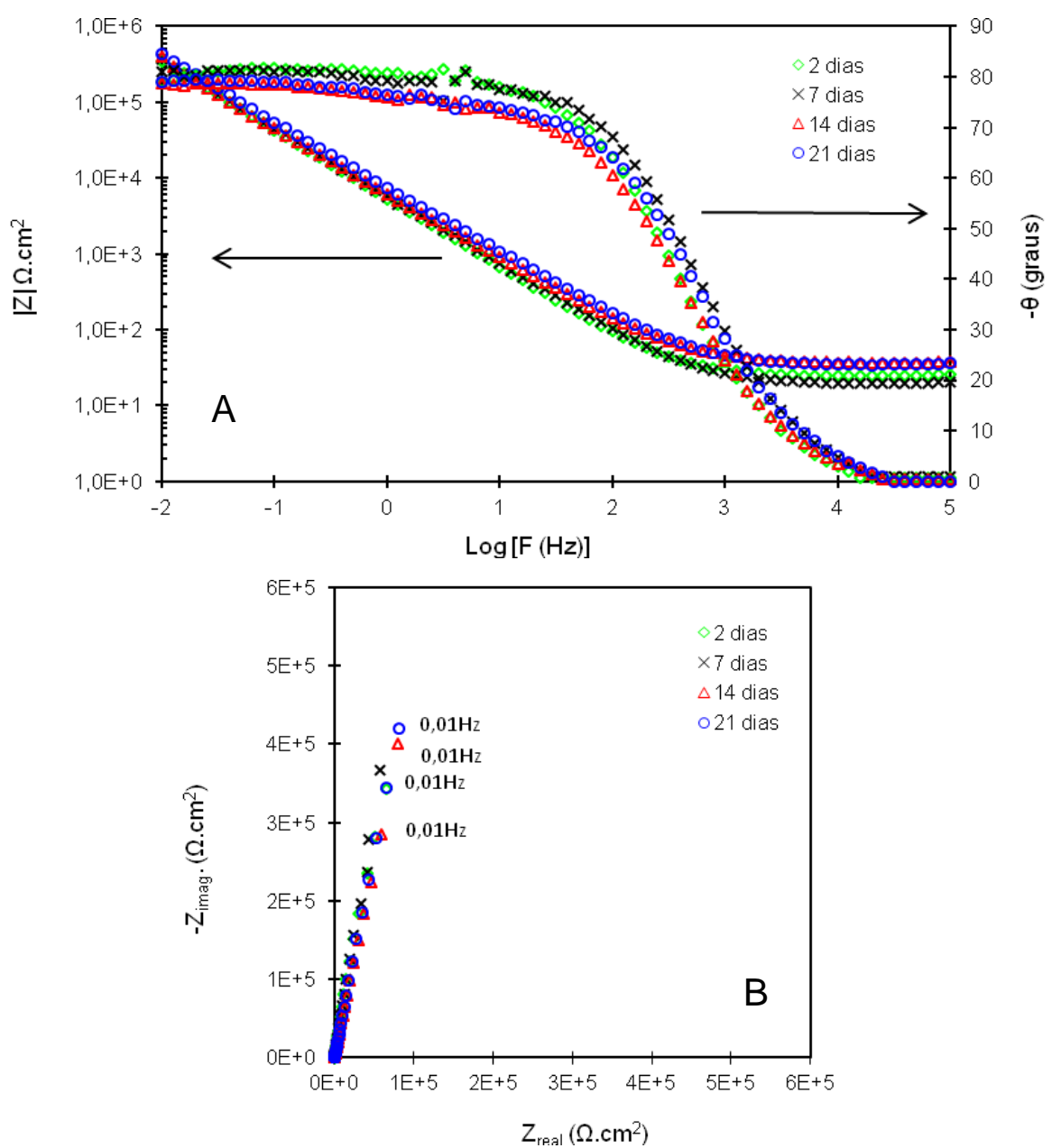

Figura 50 - Diagramas de impedância do aço AISI 444S (solubilizado), em solução PBS naturalmente aerada e a $37^{\circ}$ C. A) Diagramas de Bode. B) Nyquist.

Os diagramas de Bode (Figura 50A) revelaram poucas mudanças nas curvas de impedância, em função do tempo de imersão. Apenas os valores na região de médias e baixas frequências sofreram uma pequena redução, após 7 dias. Contudo, ainda permaneceram acima de $-70^{\circ}$, o que é característico de um sistema em estado de passividade. Todos os diagramas revelaram a presença de um ombro (entre $100 \mathrm{~Hz}$ e $10 \mathrm{~Hz}$ ), seguido por um patamar até baixas frequências. Houve uma aproximação dos valores do módulo da impedância para 
todas as frequências estudadas. Na frequência de $0,01 \mathrm{~Hz}$, todas as amostras apresentaram valores da ordem de $10^{5} \Omega . \mathrm{cm}^{2}$.

Os diagramas de Nyquist (Figura 50B) demonstraram que não ocorreu deterioração das propriedades protetoras do filme, o que foi comprovado pelo comportamento capacitivo durante todo o ensaio. Observou-se o início de um arco altamente capacitivo, para todos os períodos de imersão, que não se completou dentro da faixa de frequência estudada. Após 21 dias, notou-se um leve aumento da impedância nas baixas frequências.

\subsubsection{Aço inoxidável ferrítico NeoM}

A Figura 51 apresenta os diagramas de impedância do aço NeoM, para 2, 7, 14 e 21 dias de imersão em solução PBS.

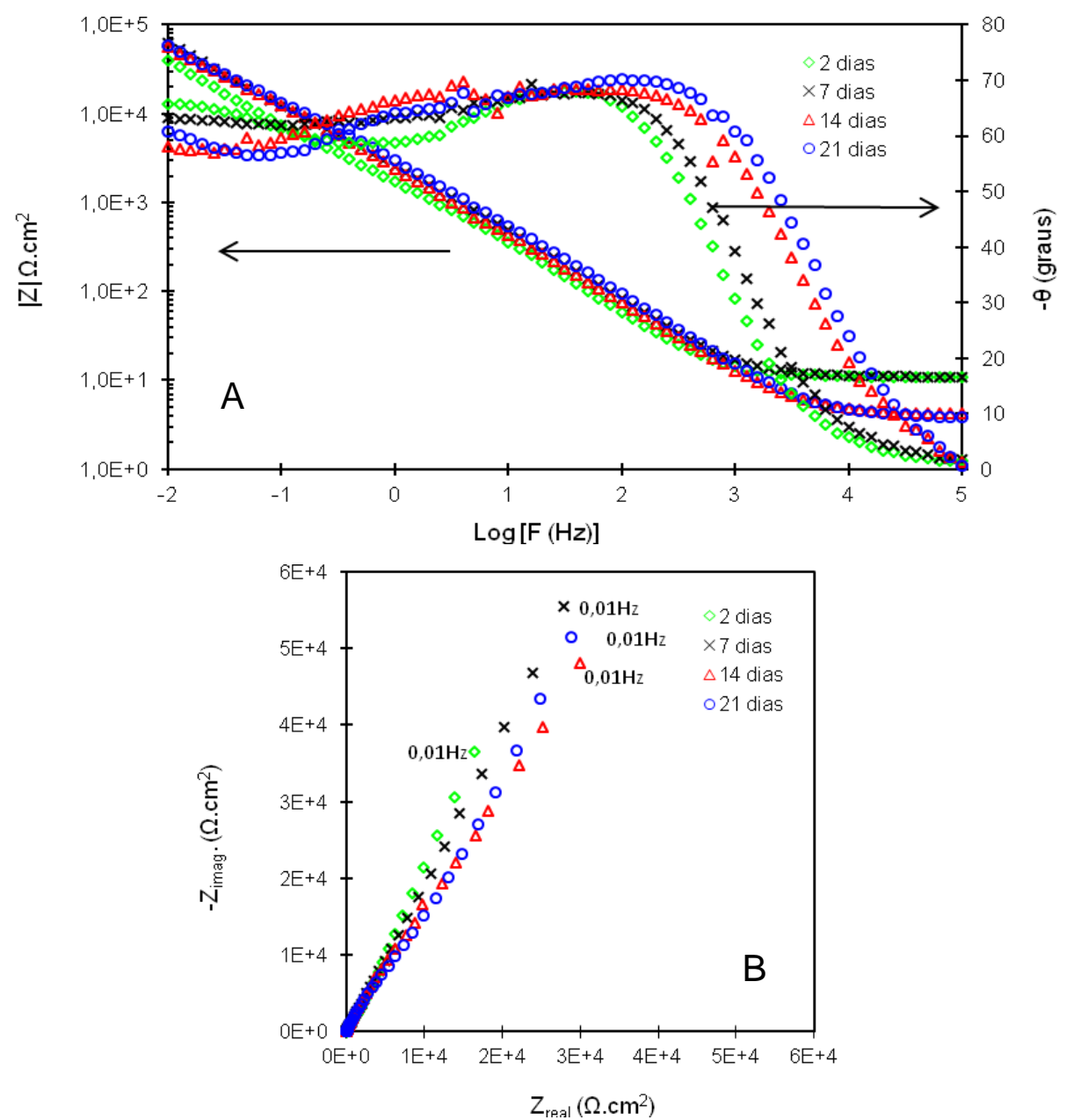

Figura 51 - Diagramas de impedância do aço NeoM, em solução PBS naturalmente aerada e a $37^{\circ} \mathrm{C}$. A) Diagramas de Bode. B) Nyquist.

Os diagramas de Bode (ângulo de fase - Figura 51A) revelaram a presença de pelo menos dois picos nas curvas para 2 e 7 dias, com a formação 
de um ombro entre $1 \mathrm{kHz}$ e $100 \mathrm{~Hz}$. Para 14 e 21 dias, observou-se a indicação de duas constantes na região entre $1 \mathrm{kHz}$ e $1 \mathrm{~Hz}$, seguido de um terceiro pico em baixa frequência $(0,01 \mathrm{~Hz})$. O que indicou a possibilidade de uma terceira constante de tempo. Após 2 dias, os módulos de impedância sofreram um pequeno aumento nas frequências abaixo de $1 \mathrm{kHz}$. Na região de $0,01 \mathrm{~Hz}$, todas as amostras apresentaram valores de impedância com grandeza da ordem de $10^{4}$ $\Omega . \mathrm{cm}^{2}$.

Nos diagramas de Nyquist da Figura 51B, observou-se o início de um arco capacitivo na região de baixas frequências, para todos os períodos de imersão. Após 2 dias de ensaio, houve um leve achatamento deste arco e aumento da impedância nas baixas frequências.

\subsubsection{Comparação dos resultados de EIE dos três aços avaliados}

Para melhor visualização dos resultados de EIE, foram plotados os gráficos comparativos dos diagramas obtidos. A Figura 52 mostra os diagramas de Bode, para os aços inoxidáveis ISO, 444, 444S e NeoM, nos períodos de imersão de 2 e 21 dias em solução PBS a $37^{\circ} \mathrm{C}$.

Os comportamentos eletroquímicos das amostras dos aços ISO, $444 \mathrm{e}$ 444S, com dois dias de imersão, foram bastante similares em todo o intervalo de frequências estudado (Figura 52A). Para o aço NeoM, no intervalo entre $1 \mathrm{kHz}$ e $10 \mathrm{~Hz}$, foi possível distinguir uma primeira constante de tempo e o início de uma segunda em frequências inferiores a $0,1 \mathrm{~Hz}$. Impedâncias menores foram associadas a este material, em comparação aos demais estudados. Os menores valores de impedância e o caráter menos capacitivo da constante de tempo, em baixas frequências, sugerem processos de transferência de carga mais rápidos na base dos defeitos da camada de óxido expondo o substrato metálico ao meio corrosivo. Para os demais materiais, aços 444, ISO e 444S, o comportamento eletroquímico foi similar em toda a faixa de frequências. Nos diagramas de Bode observou-se um patamar com ângulos de fase próximos a $-80^{\circ}$, para frequências entre $100 \mathrm{~Hz}$ e $0,01 \mathrm{~Hz}$, que são condizentes com superfícies apassivadas. 

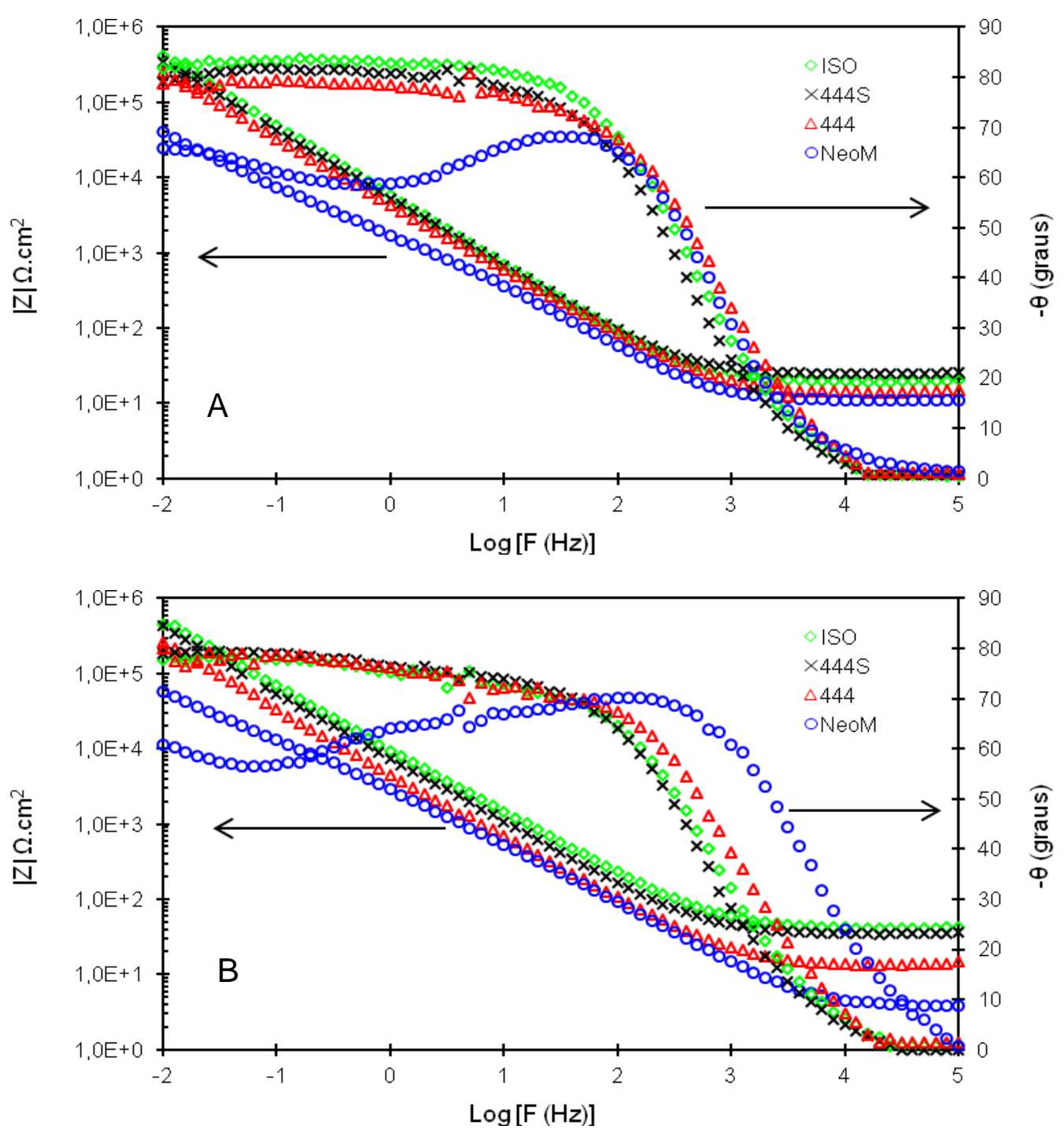

Figura 52 - Diagramas de Bode dos aços ISO, 444, 444S e NeoM, em solução PBS naturalmente aerada a $37^{\circ} \mathrm{C}$. A) 2 dias de imersão. B) 21 dias de imersão.

Nas amostras dos aços ISO, 444 e 444S, os diagramas revelaram que houve uma similaridade entre 2 e 21 dias de imersão (Figura 52A e Figura 52B, respectivamente), sugerindo uma boa estabilidade destes sistemas eletroquímicos. As altas impedâncias confirmam a elevada resistência à corrosão destas ligas. As maiores impedâncias dos aços ISO, 444 e 444S, em comparação com o aço NeoM, indicam um filme de óxido menos defeituoso e, consequentemente, mais protetor contra corrosão. No aço NeoM, após 21 dias, ocorreu um deslocamento da primeira constante de tempo para frequências mais altas, observado pelos maiores ângulos de fase. Isto sugere menor quantidade de defeitos na interface óxido-eletrólito e, portanto, um filme superficial mais protetor, em comparação com dois dias de imersão. Este resultado é apoiado pelas curvas de polarização para 2 e 21 dias (Figura 41). 
Na Figura 53 são apresentados os diagramas comparativos de Nyquist dos aços ISO, 444, 444S e NeoM, para os períodos de imersão de 2 e 21 dias, em solução PBS naturalmente aerada a $37^{\circ} \mathrm{C}$.
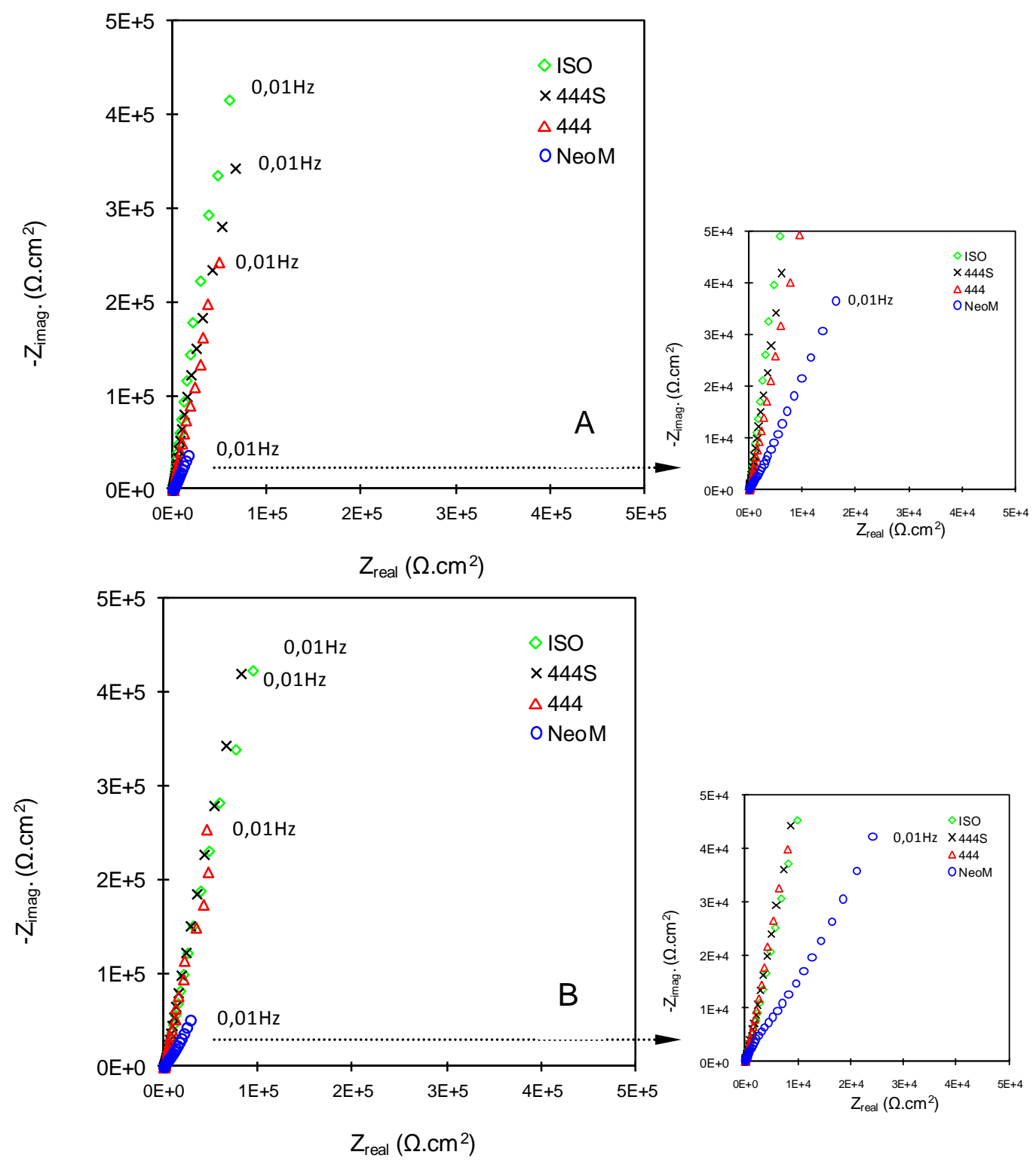

Figura 53 - Diagramas de Nyquist dos aços ISO, 444, 444S e NeoM, em solução PBS naturalmente aerada a $37^{\circ} \mathrm{C}$. A) 2 dias de imersão. B) 21 dias de imersão.

Os resultados mostraram que, para 2 dias de imersão (Figura 53A), o aço ISO apresentou as maiores impedâncias entre os materiais testados, enquanto o aço NeoM as menores. Todos as amostras tiveram pequeno aumento de impedância entre 2 e 21 dias de imersão (Figura 53B). Este resultado pode ter ocorrido em consequência do aumento de espessura do filme passivante, ou pela diminuição na densidade de defeitos no óxido. Os diagramas para o aço AISI 444S, em 21 dias, mostraram resultados similares ao do aço ISO. As amostras do aço inoxidável NeoM mantiveram o comportamento observado nos primeiros dias 
de imersão. Estes resultados indicaram a estabilidade dos sistemas eletroquímicos estudados, porém, o filme passivante sobre o aço NeoM apresentou propriedades de proteção inferiores aos demais.

\subsubsection{Circuitos elétricos equivalentes (CEE)}

Para a análise dos resultados de EIE foram testados diversos circuitos equivalentes, cujo significado físico pôde ser relacionado com o sistema avaliado. Para cada curva de EIE foi escolhido o modelo mais simples que permitiu ajuste, conforme indica a literatura (BONORA et al., 1996). Os circuitos selecionados são apresentados na Figura 54 e Figura 55.

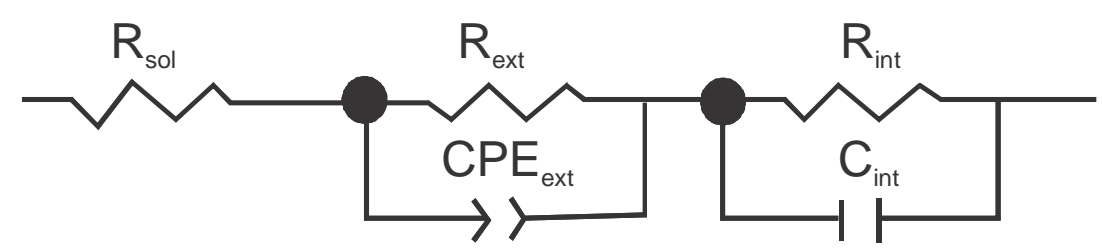

Figura 54 - Circuito elétrico equivalente proposto para caracterizar a camada passiva dos aços ISO, 444, 444S e NeoM (2 dias).

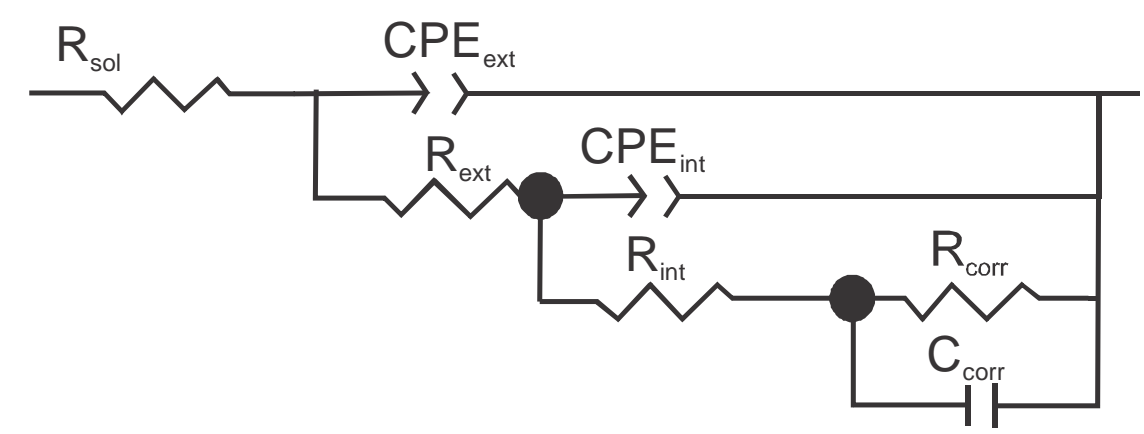

Figura 55 - Circuito elétrico equivalente proposto para caracterizar a camada passiva do aço NeoM, após 21 dias.

Para todos os materiais estudados, com exceção do aço NeoM após 21 dias de imersão, o circuito elétrico equivalente proposto na Figura 54 foi o que produziu o melhor ajuste aos dados experimentais. Apesar do CPE representar a não idealidade do sistema eletroquímico, quando se efetuaram os ajustes com dois elementos R-CPE em série, os valores de $n_{\text {int }}$ ficaram muito próximos a 1 . Isto significa que a segunda constante de tempo teve comportamento capacitivo próximo ao de um capacitor ideal. Por este motivo, foi proposto o CEE com um capacitor na segunda constante, ao invés de um CPE. Com a evolução da 
resposta eletroquímica do sistema do aço NeoM, após 21 dias, observou se o ínicio de uma terceira constante de tempo em baixas frequências. Por este motivo foi proposto o CEE da Figura 55.

A literatura sugere a formação de uma camada passiva de caráter duplex sobre os aços inoxidáveis composta por uma camada mais externa e outra mais interna (DA CUNHA BELO et al. 1998, MONTEMOR et al. 2000, HAKIKI et al. 1995, ANTUNES 2006, TERADA 2008). Segundo diversos autores, a camada mais externa, em contato com o eletrólito, é mais porosa em relação à mais interna e rica em óxidos de ferro. A camada mais interna, em contato com o substrato, é compacta e composta principalmente por óxido de cromo, sendo a principal responsável pela proteção contra a corrosão do substrato metálico.

$\mathrm{Na}$ Figura 56, observa-se a representação do modelo físico adotado para explicar o comportamento eletroquímico do filme passivo, formado sobre os aços inoxidáveis estudados, para o CEE da Figura 54.

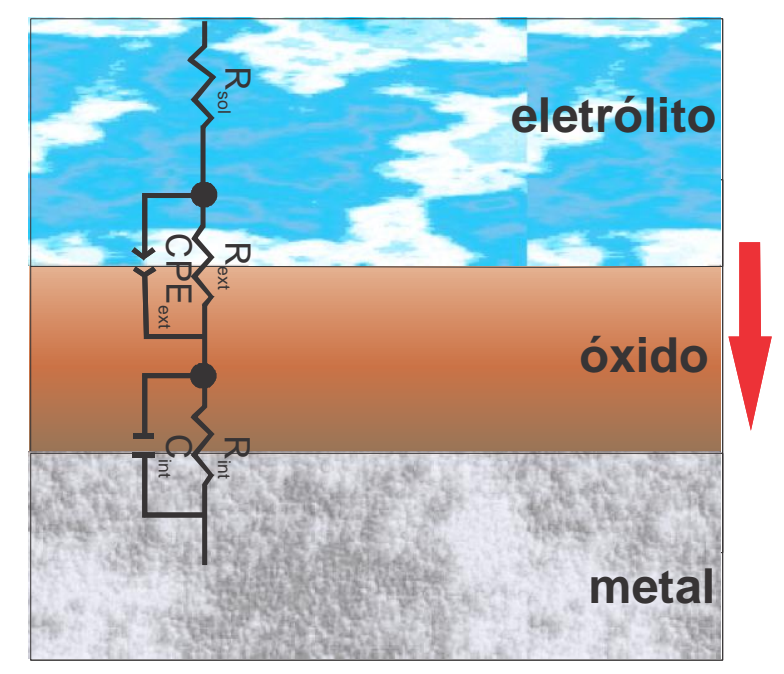

Figura 56 - Representação do modelo físico adotado para explicar o comportamento eletroquímico dos aços ensaiados, ajustado com duas constantes de tempo em série.

A Figura 56 ilustra uma amostra de aço inoxidável imerso no eletrólito. A resistência do eletrólito é descrita pelo elemento $R_{\text {sol }}$. Em série com este elemento tem-se um par $R_{\text {ext }}-C P E_{\text {ext }}$, o qual é seguido por outro par $R_{\text {int }}-C_{\text {int }}$, também em série. A primeira constante de tempo $\left(R_{\text {ext }}-C E_{\text {ext }}\right)$ representa os processos eletroquímicos na interface eletrólito/filme passivo. $O R_{\text {ext }}$ é a resistência à transferência de carga entre o filme óxido e o eletrólito. $\mathrm{O} C P \mathrm{E}_{\text {ext }}$ modela a capacitância do filme óxido. $O$ segundo par $\left(R_{\text {int }}-C_{\text {int }}\right)$ representa 
processos transferenciais na interface substrato metálico - filme óxido. $O R_{\text {int }}$ simula a resistência à transferência de carga na interface metal-filme óxido e o $\mathrm{C}_{\text {int }}$ o carregamento da dupla camada elétrica nesta interface.

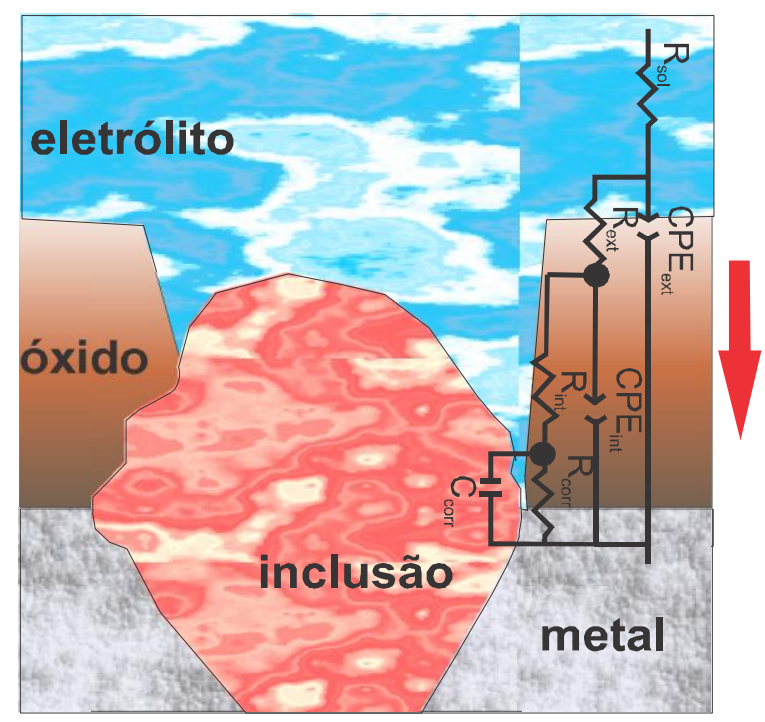

Figura 57 - Representação do modelo físico adotado para explicar o comportamento eletroquímico do aço $\mathrm{NeoM}$, ajustado com três constantes de tempo.

Na Figura 57 é esquematizado o modelo físico adotado para explicar o comportamento eletroquímico do aço NeoM, em 21 dias, segundo o CEE proposto. A resistência do meio é representada por $R_{\text {sol. }}$. Esta é seguida por um par $\mathrm{R}-\mathrm{CPE} \mathrm{E}_{\mathrm{ext}}$ que representa os processos eletroquímicos na interface eletrólito/filme passivo. Em cascata com $R_{\text {ext }}$ há outra constante de tempo ( $R$ $\mathrm{CPE}_{\text {int }}$ ) proposta para simular os processos de transferência de carga $\mathrm{e}$ carregamento da dupla camada elétrica na interface óxido-eletrólito. A terceira constante de tempo (R-CPE $E_{\text {corr }}$ ), em cascata com $R_{\text {int }}$, representa a capacitância e resistência do processo de corrosão na região de interface entre a inclusão e o substrato metálico, onde há descontinuidade do filme passivo. É importante salientar que as camadas representadas não estão em suas devidas proporções, tratando-se de um modelo representativo, uma vez que o filme passivo é extremante fino.

$\mathrm{Na}$ Tabela 13 tem-se os valores dos componentes dos CEE, obtidos pelos ajustes dos resultados experimentais de EIE em 2 dias de imersão. Os valores ajustados para 21 dias são apresentados na Tabela 14. Os erros correspondentes a cada componente estão presentes no ANEXO I. 
Tabela 13 - Valores dos elementos dos circuitos elétricos equivalentes ajustados sobre os resultados de EIE dos aços ISO, 444 e 444S, após 2 dias de imersão, em meio PBS naturalmente aerado a $37^{\circ} \mathrm{C}$.

\begin{tabular}{l|c|c|c|c}
\hline & $\mathbf{I S O}$ & $\mathbf{4 4 4}$ & $\mathbf{4 4 4 S}$ & $\mathbf{N e O M}$ \\
\hline $\mathbf{R}_{\text {sol }}\left(\Omega \cdot \mathbf{c m}^{2}\right)$ & 19,26 & 13,71 & 24,36 & 10,31 \\
\hline $\mathbf{C P E}_{\text {ext }}\left(\mathbf{c m}^{-2} \mathbf{s}^{-\mathbf{n}} \boldsymbol{\Omega}\right)$ & $1,39 \times 10^{-4}$ & $1,21 \times 10^{-4}$ & $1,22 \times 10^{-4}$ & $1,34 \times 10^{-4}$ \\
\hline $\mathbf{n}_{\text {ext }}$ & 0,78 & 0,77 & 0,78 & 0,77 \\
\hline $\mathbf{R}_{\text {ext }}\left(\Omega \cdot \mathbf{c m}^{2}\right)$ & $1,82 \times 10^{4}$ & $1,91 \times 10^{4}$ & $2,02 \times 10^{4}$ & $4,11 \times 10^{3}$ \\
\hline $\mathbf{C}_{\text {int }}\left(\mathbf{F} . \mathrm{cm}^{2}\right)$ & $3,65 \times 10^{-5}$ & $6,19 \times 10^{-5}$ & $4,41 \times 10^{-5}$ & $3,26 \times 10^{-4}$ \\
\hline $\mathbf{R}_{\text {int }}\left(\Omega . \mathbf{c m}^{2}\right)$ & $3,57 \times 10^{6}$ & $1,62 \times 10^{6}$ & $2,25 \times 10^{6}$ & $9,29 \times 10^{4}$ \\
\hline
\end{tabular}

Tabela 14 - Valores dos elementos dos circuitos elétricos equivalentes ajustados sobre os resultados de EIE dos aços ISO, 444 e 444S, após 21 dias de imersão, em meio PBS naturalmente aerado a $37^{\circ} \mathrm{C}$

\begin{tabular}{l|c|c|c|c}
\hline & $\mathbf{I S O}$ & $\mathbf{4 4 4}$ & $\mathbf{4 4 4 S}$ & $\mathbf{N e o M}$ \\
\hline $\mathbf{R}_{\text {sol }}\left(\Omega \cdot \mathbf{c m}^{2}\right)$ & 39,98 & 13,34 & 33,85 & 30,7 \\
\hline $\mathbf{C P E} \mathbf{E}_{\text {ext }}\left(\mathbf{c m}^{-2} \mathbf{s}^{-\mathbf{n}} \Omega\right)$ & $4,99 \times 10^{-5}$ & $9,42 \times 10^{-5}$ & $6,82 \times 10^{-5}$ & $4,83 \times 10^{-5}$ \\
\hline $\mathbf{n}_{\text {ext }}$ & 0,74 & 0,77 & 0,75 & 0,84 \\
\hline $\mathbf{R}_{\text {ext }}\left(\Omega \cdot \mathbf{c m}^{2}\right)$ & $3,57 \times 10^{4}$ & $6,0 \times 10^{3}$ & $2,50 \times 10^{4}$ & $1,42 \times 10^{3}$ \\
\hline $\mathbf{C}_{\text {int }}\left(\mathbf{F} . \mathrm{cm}^{2}\right)$ & $2,91 \times 10^{-5}$ & $5,38 \times 10^{-5}$ & $3,58 \times 10^{-5}$ & - \\
\hline $\mathbf{C P E} E_{\text {int }}$ & - & - & - & $4,06 \times 10^{-5}$ \\
\hline $\mathbf{R}_{\text {int }}\left(\Omega . \mathbf{c m}^{2}\right)$ & $2,82 \times 10^{6}$ & $1,01 \times 10^{6}$ & $2,66 \times 10^{6}$ & $4,46 \times 10^{5}$ \\
\hline $\mathbf{C}_{\text {corr }}$ & - & - & - & $1,20 \times 10^{-4}$ \\
\hline $\mathbf{R}_{\text {corr }}$ & - & - & - & $2,66 \times 10^{5}$ \\
\hline
\end{tabular}

A relação entre capacitância e espessura é definida pela Equação 3 , onde $\mathcal{E}$ é a constante dielétrica do filme passivo, $\boldsymbol{\varepsilon}_{0}$ o valor da permissividade do vácuo, $\mathbf{A}$ a área da superfície e $\mathbf{d}$ a espessura da camada passiva (Rondelli, et al., 2005). Segundo esta equação, os valores de espessura e capacitância são inversamente proporcionais.

$$
C=\varepsilon \cdot \varepsilon_{0} \cdot A / d
$$

Equação 3

Conforme os resultados dos ajustes por CEE, para 2 dias de imersão (Tabela 13), o valor do $\mathrm{CPE}_{\text {ext }}$ foi da ordem de $10^{-4} \mathrm{~cm}^{-2} \mathrm{~s}^{-n} \Omega$ para todos os materiais. Após 21 dias, todos tiveram uma pequena redução neste parâmetro. Para a $\mathrm{C}_{\text {int }}$ (ISO,444 e 444S) e CPE $\mathrm{C}_{\text {int }}$ (NEO) observou-se que, assim com no $\mathrm{CPE}_{\text {ext }}$, houve redução no valor de 2 para 21 em todas as amostras. Com base nos valores de capacitância, concluiu-se que ocorreu um aumento de espessura do filme passivo, entre 2 e 21 dias, para todos os materiais. 
Com relação aos valores da $R_{\text {ext, }}$ para os quatro aços, observou-se que houve aumento na resistência de 2 para 21 dias, o que sugeriu uma melhor capacidade protetora do filme na interface filme/eletrólito. Comparando os resultados de $R_{\text {int }}$ com $R_{\text {ext }}$, nota-se que o primeiro é de uma a três ordens de grandeza maior que o segundo. Considerando a resistência à polarização (Rp) total do sistema, fica evidente que a $R_{\text {int }}$, a qual representa a interface filme óxido/metal, é a principal responsável pela resistência à transferência de carga, e consequentemente, velocidade do processo de corrosão. O aço NeoM apresentou o valor de $\mathrm{R}_{\text {int }}$ da ordem de $10 .{ }^{5} \Omega . \mathrm{cm}^{2}$. Apesar de ser um valor elevado, é cerca de 10 vezes inferior aos demais materiais testados. Segundo WOLYNEC (2003) uma redução no valor da $\mathrm{Rp}$ significa um aumento da corrosividade do meio. Pode-se concluir que este material apresenta menor resistência à transferência de cargas, entre o substrato e o filme, o que o torna mais suscetível à corrosão, comparado aos demais aços testados.

\subsection{Propriedades eletrônicas do filme passivo - Gráficos de Mott-Schottky}

O filme passivo, formado sobre os aços inoxidáveis, possui características semicondutoras e suas propriedades eletrônicas desempenham um papel importante na resistência à corrosão (HAKIKI et al, 1995). Com o objetivo de estudar estas propriedades, foi proposta a metodologia de MottSchottky, que permitiu comparar as propriedades eletrônicas do filme passivo do aço AISI 444 com as do filme formado sobre o aço NeoM.

Segundo diversos autores (HAKIKI et al., 1995, HAKIKI e DA CUNHA BELO, 1998, MARTINI e MULLER, 2000, MONTEMOR et al., 2000, ANTUNES 2006, TERADA 2008), o filme passivo dos aços inoxidáveis é descrito por um modelo de camada duplex, formado por uma camada externa rica em óxidos/hidróxidos de ferro e uma camada interna, rica em óxido de cromo. A camada externa apresenta comportamento de um semicondutor extrínseco tipo-n e a interna do tipo-p. Os gráficos de Mott-Schottky, representando $1 / C^{2}$ versus $\mathrm{E}$ (potencial), têm uma inclinação negativa, quando o óxido responsável pelas medidas de capacitância for tipo-p e positiva quando tipo-n. A parte de inclinação positiva da reta, relacionada às polarizações acima do potencial de banda plana $\left(E_{\mathrm{bp}}\right)$, apresenta excesso de cargas negativas (doadores). Estas são geradas pelas lacunas de íons metálicos das camadas externas, ricas em óxidos e 
hidróxidos de ferro. $\mathrm{O}$ número de dopantes foi representado pela abreviação $N_{D}$ (número de doadores), toda vez que se referir a esta parte do gráfico de MottSchottky. Por outro lado, a parte de inclinação negativa da reta, referente aos valores de $1 / C^{2}$ abaixo do potencial $E_{b p}$, está associada a um semicondutor extrínseco tipo-p. Este semicondutor apresenta excesso de cargas positivas, geradas pelas lacunas ou buracos eletrônicos das camadas internas de óxido de cromo e, portanto, são aceitadores de cargas. O número de dopantes foi representado pela abreviação $\mathrm{N}_{\mathrm{A}}$ (número de aceitadores). Para determinar $\mathrm{o}$ potencial de banda plana $\left(E_{b p}\right)$, foi utilizado o método de extrapolação das retas de inclinação positiva e negativa, conforme exemplificado na Figura 58.

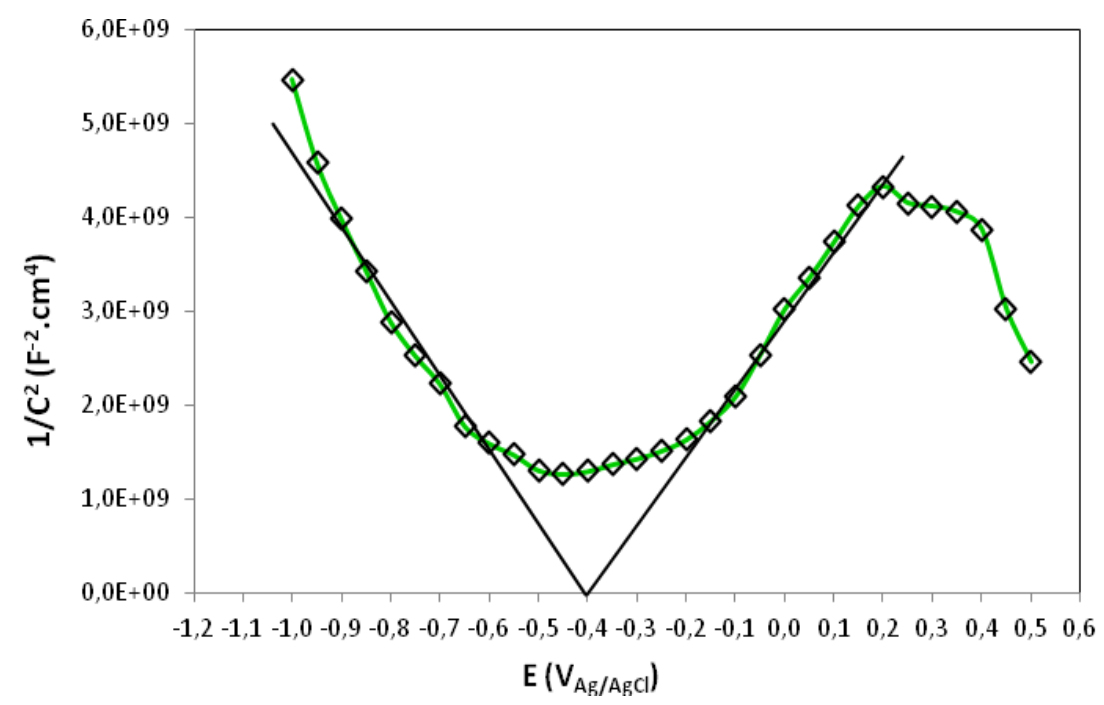

Figura 58 - Exemplo de método de extrapolação para determinação do potencial de banda plana. Curva experimental do aço NeoM após 21 dias de imersão.

\subsubsection{Aço inoxidável Neo Magnet}

Na Figura 59, são apresentados os gráficos de Mott-Schottky para o aço inoxidável NeoM, após 2, 7, 14 e 21 dias de imersão, em solução PBS naturalmente aerada a $37^{\circ} \mathrm{C}$.

Observou-se que para este material há duas inclinações bem distintas, confirmando a presença de um óxido com estrutura eletrônica duplex, uma parte com propriedades eletrônicas predominantes de um semicondutor tipo-p, e outra com propriedades predominantes de um condutor do tipo-n. 


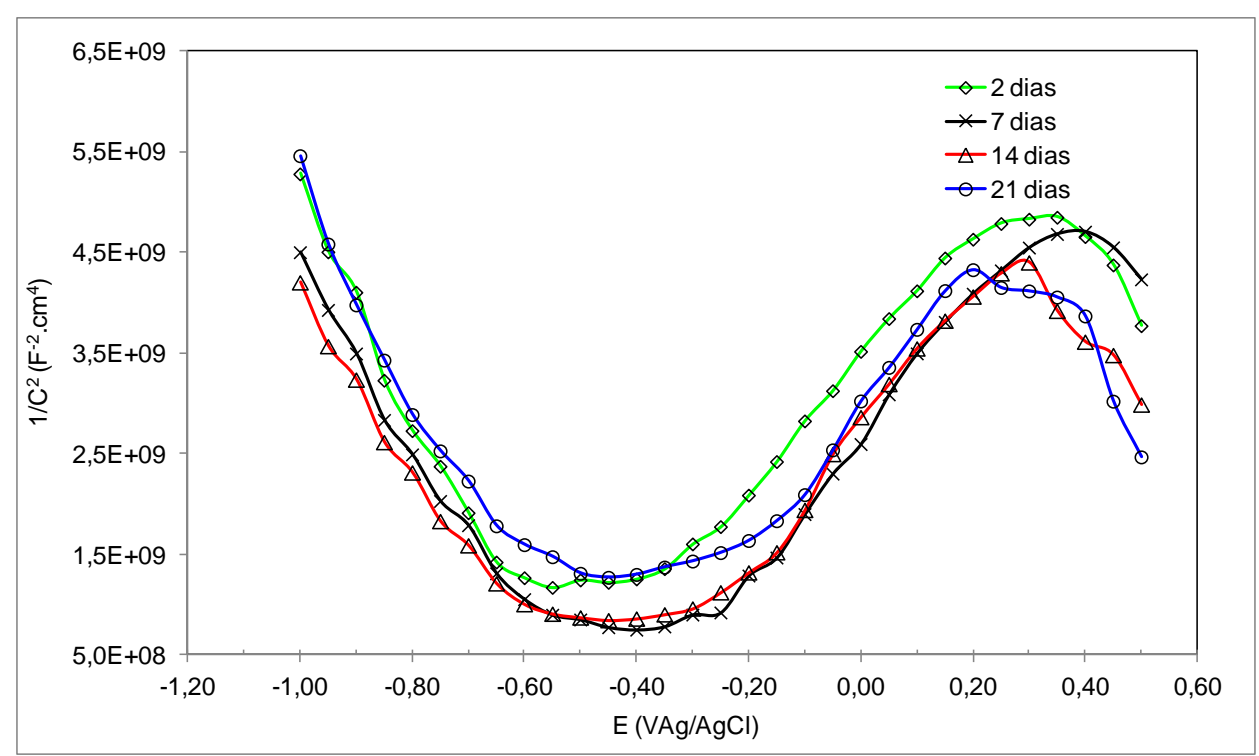

Figura 59 - Gráficos de Mott-Schottky para o aço NeoM em solução PBS, naturalmente aerada a $37^{\circ} \mathrm{C}$.

O potencial de banda plana $\left(E_{\mathrm{bp}}\right)$, para os quatros períodos estudados, foi de aproximadamente $-0,4 \mathrm{~V}$. Este valor está de acordo com os $\mathrm{E}_{\mathrm{bp}}$ descritos por outros autores para aços inoxidáveis com camada passiva duplex (HAKIKI et al.1995; DA CUNHA BELO et al. 1998; MONTEMOR et al. 2000, ANTUNES 2000 e TERADA 2008). Descrevendo-se a parte do gráfico correspondente aos doadores de cargas (inclinação positiva para potencial $>E_{b p}$ ), observou-se que as curvas referentes ao filme passivo, após 7, 14 e 21 dias, mostraram inclinações similares, porém, ligeiramente, mais acentuadas que a observada em 2 dias de ensaio. Para a região de inclinação negativa (potencial entre $-0,4 \vee$ e $-1 \mathrm{~V}$ ), responsável pela resposta dos semicondutores extrínsecos tipo-p, notou-se pequenas alterações de inclinação, que serão discutidas após o cálculo do número de dopantes, para cada região e período de imersão.

$\mathrm{Na}$ Figura 60, são apresentadas as densidades de doadores de carga no filme passivo $\left(\mathrm{N}_{\mathrm{D}}\right)$, determinadas a partir dos gráficos de Mott-Schottky (Figura 59) na região de inclinação positiva (potenciais entre $-0,4 \vee$ e $+0,5 \mathrm{~V}$ ). 


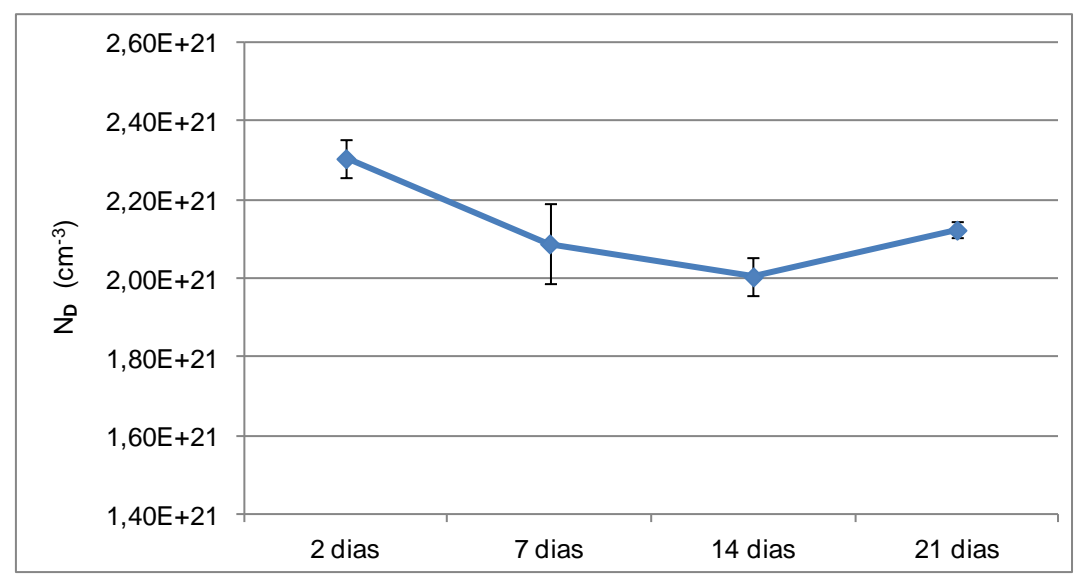

Figura 60 - Valores da concentração de doadores de carga no filme passivo do NeoM, determinados a partir dos gráficos de Mott-Schottky da Figura 59, na região de potenciais entre $-0,4 \mathrm{~V}$ e $+0,5 \mathrm{~V}$.

Pelos valores obtidos na Figura 60, verificou-se uma redução progressiva do número de doadores entre 2 e 14 dias de imersão, seguido por um ligeiro aumento em 21 dias. Estes resultados sugerem que a camada mais externa do filme passivo, rica em óxido de ferro, apresentou características mais favoráveis à condução de cargas em 2 dias, ou seja, nos períodos iniciais de imersão, quando o filme ainda não era suficientemente espesso, a movimentação de cargas no interior do filme foi mais favorável do que nos demais períodos. As concentrações de dopantes foram da ordem de $10^{21}$ dopantes. $\mathrm{cm}^{-3}$.

Na Figura 61, são apresentadas as densidades de aceitadores de carga no filme passivo $\left(\mathrm{N}_{\mathrm{A}}\right)$, determinadas a partir dos gráficos de Mott-Schottky (Figura 59) na região de inclinação negativa $\left(<\mathrm{E}_{\mathrm{bp}}\right)$.

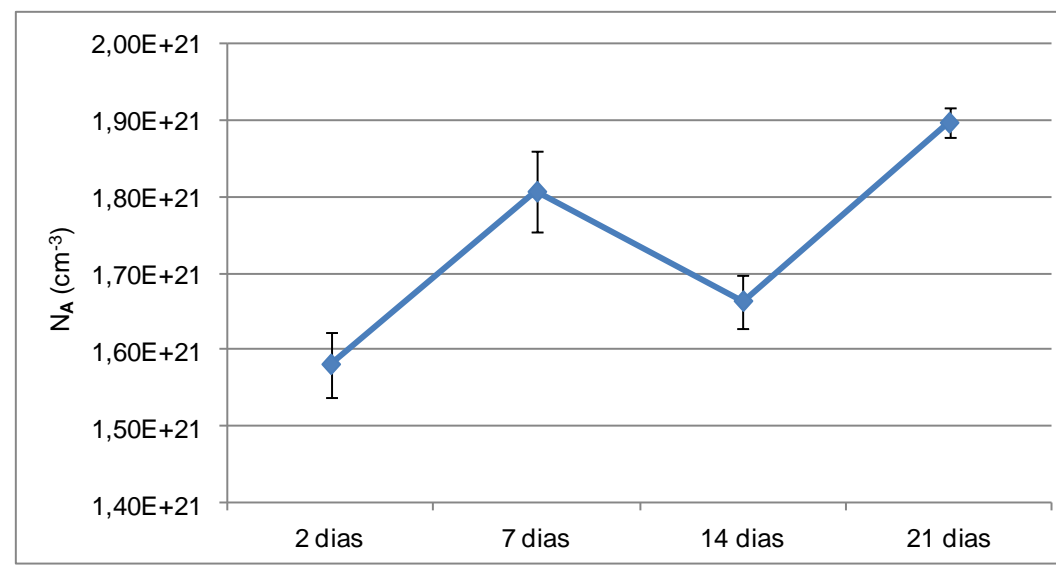

Figura 61 - Valores da concentração de aceitadores de carga no filme passivo do aço NeoM, determinados a partir dos gráficos de Mott-Schottky da Figura 59, na região de potenciais entre $-1 \mathrm{~V}$ e $-0,4 \mathrm{~V}$. 
Para o óxido semicondutor tipo-p (Figura 61), houve elevação no número de dopantes entre 2 e 21 dias de imersão. Este resultado indicou um aumento dos portadores majoritários de carga, presentes no filme óxido após 21 dias, e, consequentemente, uma maior condutividade eletrônica. A densidade de aceitadores de carga foi da ordem de $10^{21}$ dopantes $/ \mathrm{cm}^{3}$.

$\mathrm{Na}$ Figura 62, observa-se a concentração de dopantes do filme passivo do aço NeoM para os aceitadores e os doadores de carga.

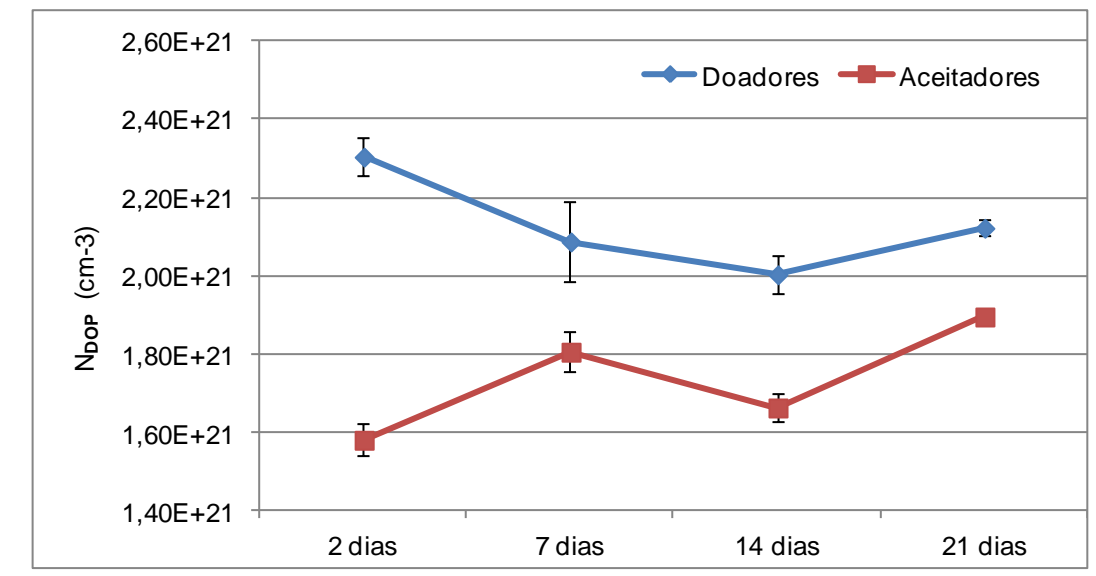

Figura 62 - Valores da concentração de dopantes no filme passivo do aço NeoM, determinados a partir dos gráficos de Mott-Schottky (Figura 59).

Os resultados da Figura 62 indicaram pequenas variações na concentração de ambos os tipos de dopantes. Isto significou que o filme teve suas propriedades eletrônicas alteradas, devido às espécies agressivas do meio, as quais foram capazes de provocar a formação de lacunas de íons metálicos e buracos eletrônicos. Ao mesmo tempo em que ocorre crescimento de defeitos, tem-se também a recuperação do filme. As variações no número de dopantes podem ser explicadas pelo processo de ataque e recuperação que o filme sofre no meio. Segundo TAVEIRA et al. (2010), um filme sobre aço inoxidável altamente dopado possui densidade de dopantes da ordem de $10^{19}$ a $10^{20}$ dopantes. $\mathrm{cm}^{-3}$. O aço NeoM apresentou concentrações dez vezes maiores, da ordem de $10^{21}$ dopantes. $\mathrm{cm}^{-3}$.

\subsubsection{Aço inoxidável AISI 444}

Na Figura 63, são apresentados os gráficos de Mott-Schottky para o aço inoxidável AISI 444, após 2, 7, 14 e 21 dias de imersão, em solução PBS naturalmente aerada a $37^{\circ} \mathrm{C}$. 


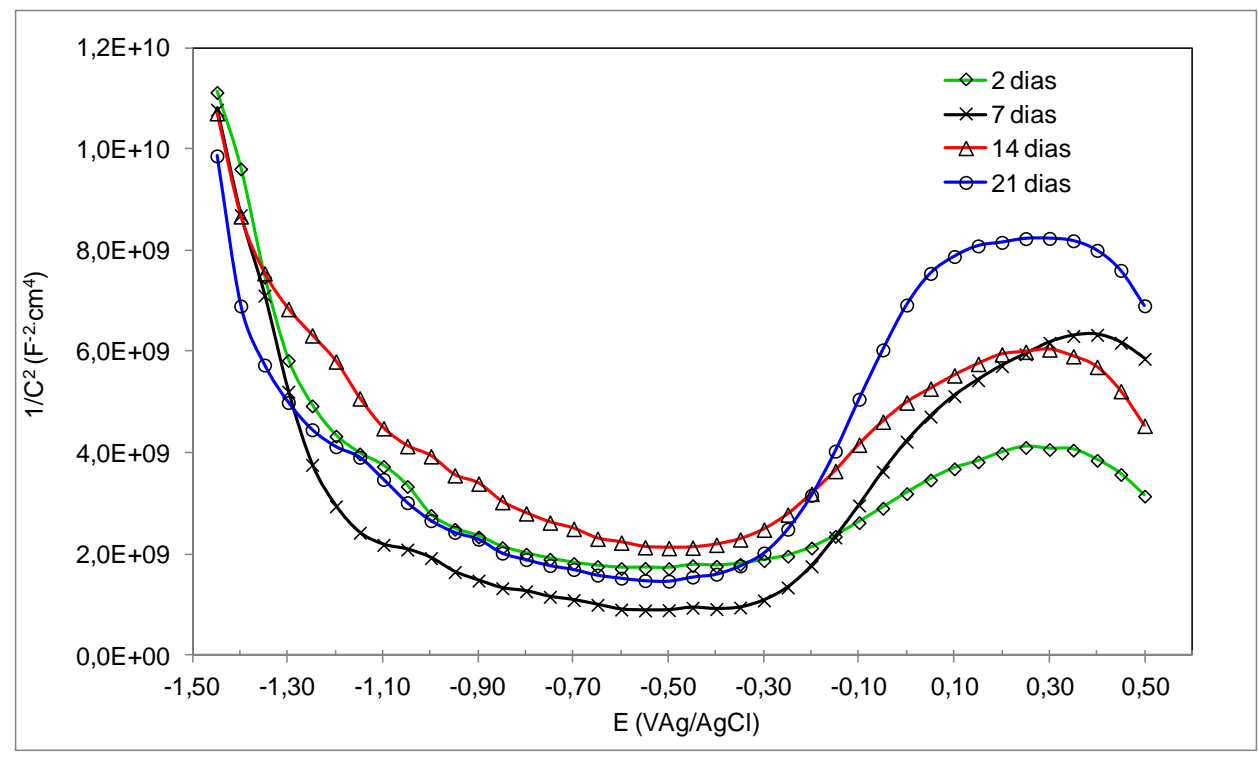

Figura 63 - Gráficos de Mott-Schottky para o aço AISI 444 em solução PBS, naturalmente aerada a $37^{\circ} \mathrm{C}$.

Observando-se as curvas obtidas pela técnica de Mott-Schottky para o aço AISI 444 (Figura 63), verificou-se um comportamento típico de um filme passivo duplex, cujos óxidos apresentaram respostas de um semicondutor extrínseco tipo-n, na região de potencial $>E_{b p}$, e comportamento de um semicondutor extrínseco tipo-p, na faixa de potencial $<\mathrm{E}_{\mathrm{bp}}$.

Nas curvas, referentes à capacitância de um semicondutor tipo-n, notou-se diferentes inclinações para cada período de imersão, sendo a maior verificada em 21 dias. Enquanto nas curvas, referentes à capacitância de um semicondutor tipo-p, não foi possível diferenciar as inclinações entre elas.

Tendo por base as curvas de Mott-Schottky (Figura 63), foram calculadas as densidades de doadores de carga no filme passivo sobre o aço AISI 444 (Figura 64). 


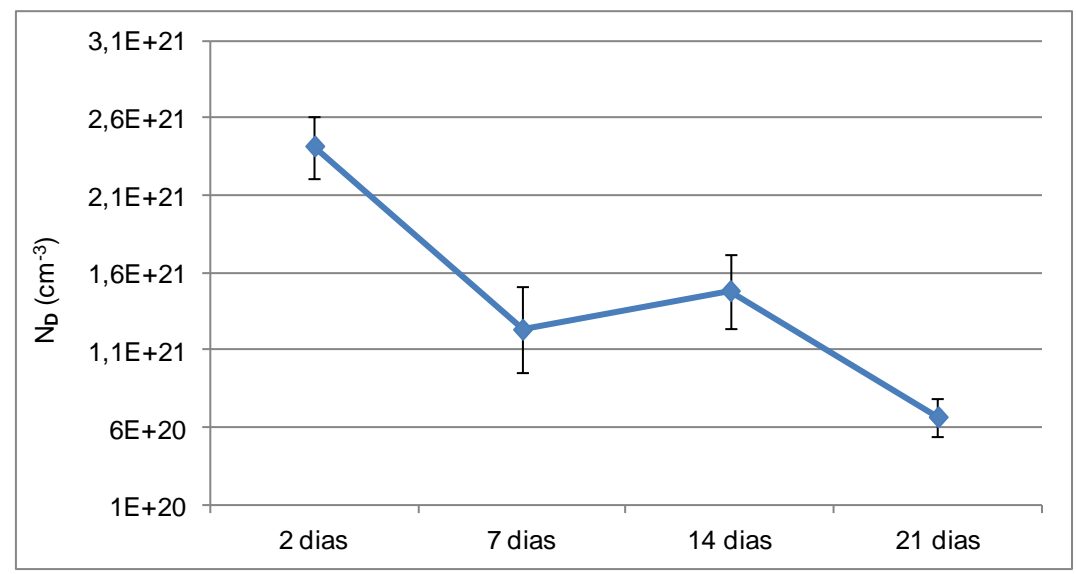

Figura 64 - Valores da concentração de doadores de carga no filme passivo do aço AISI 444, determinados a partir dos gráficos de Mott-Schottky (Figura 63) na região de potenciais $>E_{b p}$.

As concentrações de dopantes, no óxido externo semicondutor tipo-n (Figura 64), sugeriram que o filme passivo tornou-se menos condutor após 21 dias. O pico no número de dopantes, em 2 dias, indicou maior número de defeitos no filme neste período, relacionados à formação de lacunas de íons metálicos (excesso de elétrons na camada de valência). A grande variação na concentração de doadores de carga, entre 2 e 21 dias, indicou que a camada externa do filme sofreu constantes modificações devido à ação do meio.

Pelas inclinações das curvas obtidas nos diagramas de Mott-Schottky (Figura 63), foram calculadas as concentrações de aceitadores de carga no filme passivo (Figura 65) sobre o aço 444, entre 2 e 21 dias de imersão na solução PBS.

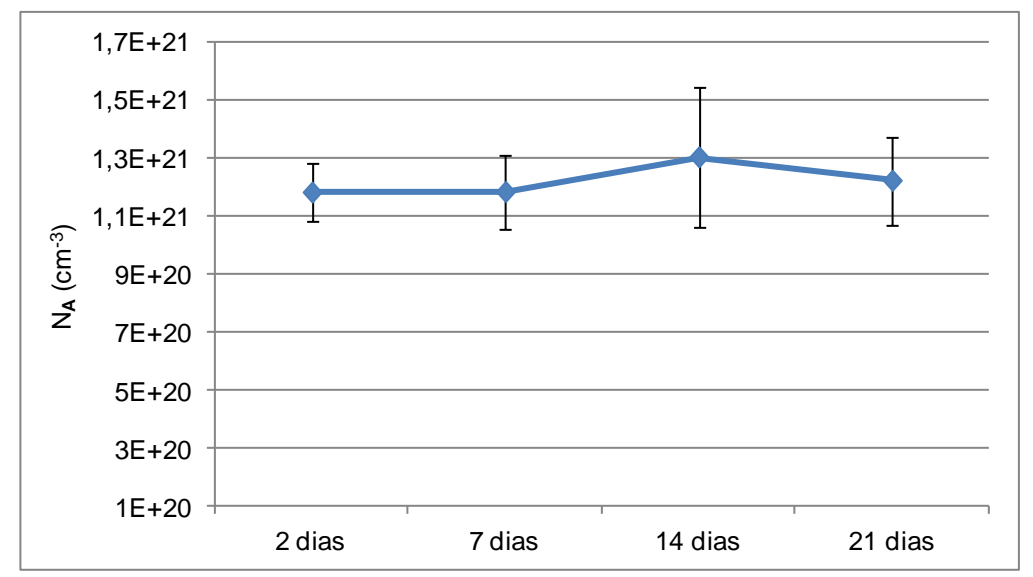

Figura 65 - Valores da concentração de aceitadores de carga no filme passivo do aço 444, determinados a partir dos gráficos de Mott-Schottky (Figura 63) na região de potenciais $<\mathrm{E}_{\mathrm{bp}}$. 
A densidade de aceitadores, no filme formado sobre as amostras do aço 444, apresentou pouca variação para todos os períodos de imersão. Isto indicou uma estabilidade desta camada no meio de ensaio.

Na Figura 66 tem-se a concentração de dopantes, no filme óxido sobre o aço 444, para os aceitadores e os doadores de carga.

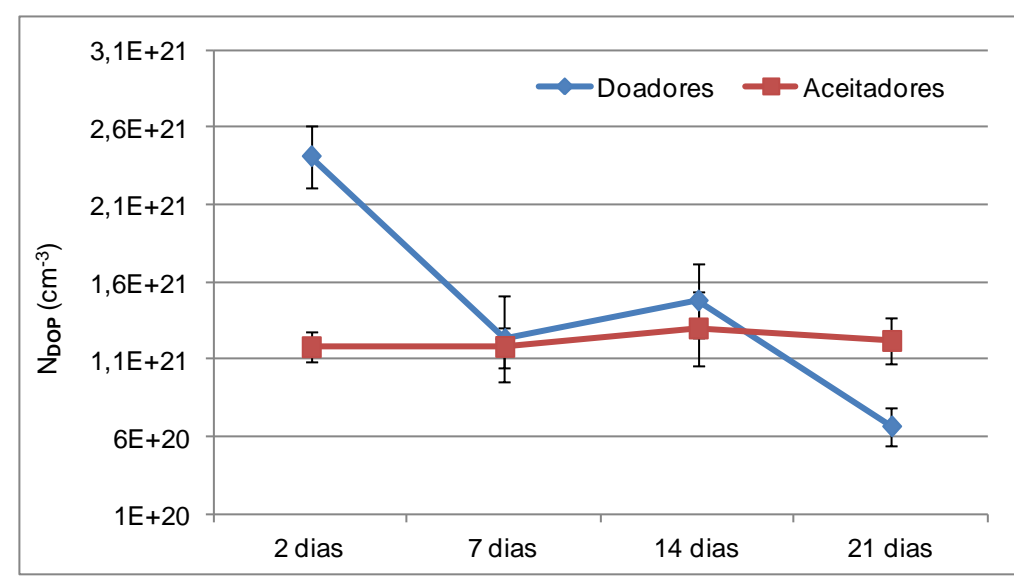

Figura 66 - Valores da concentração de dopantes no filme passivo do aço 444, determinados a partir dos gráficos de Mott-Schottky (Figura 63).

A Figura 66 mostrou redução do número doadores de carga entre 2 e 21 dias, enquanto a concentração de aceitadores manteve-se praticamente estável no período. Isto sugere que a parte mais externa do filme de óxido (rica em óxido de ferro) tornou-se menos defeituosa, provavelmente devido ao preenchimento das lacunas eletrônicas por reagentes do meio. Em contrapartida, a camada mais interna do filme (principal responsável pela resistência à corrosão), manteve-se praticamente invariável no eletrólito (solução PBS), o que foi apoiado pelo comportamento altamente capacitivo, indicado nos diagramas de EIE (Figura 49).

4.7.3 Comparação dos resultados de Mott-Schottky entre os aços inoxidáveis AISI 444 e Neo Magnet

Uma comparação entre as características semicondutoras dos filmes óxidos, especificamente as densidades de dopantes, foi realizada para os aços $\mathrm{NeoM}$ e 444, sendo estas calculadas a partir das curvas de Mott-Schottky. Na Figura 67 são apresentadas as densidades de doadores e aceitadores de carga para os aços 444 e NeoM, em 2 e 21 dias de imersão. 

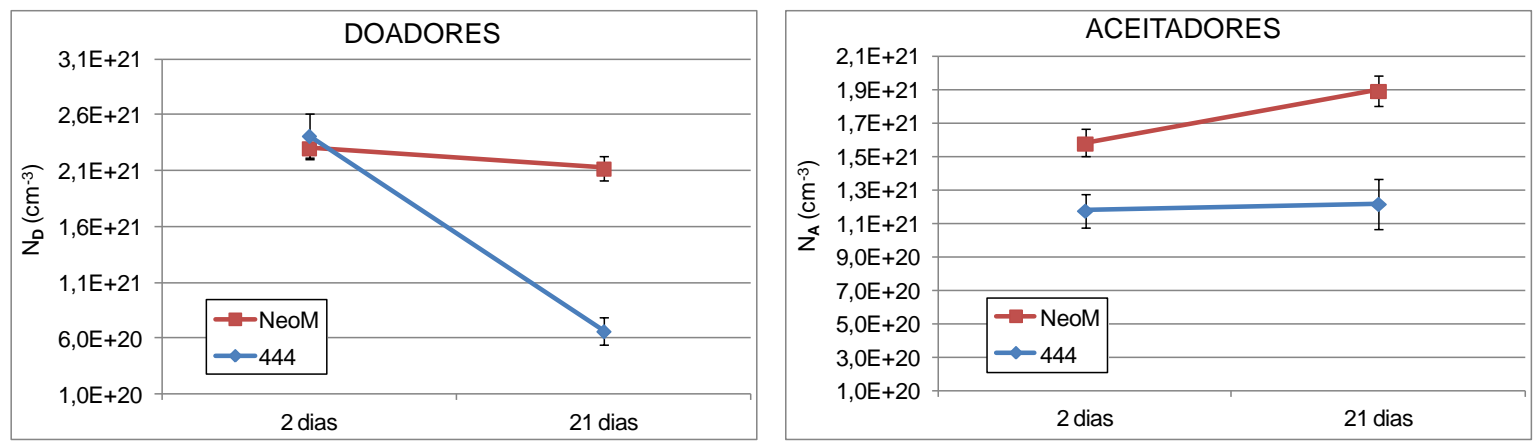

Figura 67 - Valores da concentração de doadores e aceitadores de carga no filme passivo sobre os aços 444 e NeoM.

Os resultados da Figura 67 mostraram que a concentração de doadores de carga (óxido semicondutor tipo-n e mais externo na camada), no período de 2 dias, foi equivalente para os dois aços. Após 21 dias de ensaio, houve uma significativa redução desta concentração para o aço AISI 444, enquanto que para o aço NeoM a concentração manteve-se próxima do inicial. O aumento da impedância, entre 2 e 21 dias, observado pelos resultados de EIE, apoia esta hipótese.

A densidade de aceitadores de carga para o aço AISI 444 (óxido semicondutor tipo-p e mais interno na camada) estatisticamente não variou, enquanto que para o aço NeoM ocorreu um discreto aumento entre 2 e 21 dias. Este resultado indicou que a camada mais interna, rica em óxido de cromo, foi estável para o aço 444, enquanto que para o aço NeoM tornou-se mais condutora com o tempo de imersão, provavelmente, devido à grande quantidade de precipitados na estrutura do filme sobre este último aço.

A propriedade de proteção contra a corrosão de filmes passivantes depende, entre outros fatores, de suas propriedades eletrônicas. Contudo, é importante salientar que podem ocorrer divergências entre os resultados eletroquímicos e a expectativa com relação à densidade de dopantes no filme óxido. Para TAVEIRA et al. (2010), os valores de capacitância obtidos por diagramas de Mott-Schottky, após tratamento de passivação do aço AISI 304, podem ser influenciados pela alteração na área ativa de contato entre o filme passivo e o meio. De acordo com SATO (1990), a permeabilidade iônica e a morfologia do filme influenciam as propriedades eletrônicas e sua resistência à corrosão.

Deve-se considerar, portanto, que a condutividade eletrônica do filme óxido não é o único fator a influenciar em sua resistência à corrosão. A presença 
de precipitados, que provocam descontinuidades na camada passiva, é um fator de grande importância na resistência do filme ao ataque corrosivo (CASTLE e CLAYTON, 1977).

Para ambos os aços, os valores dos aceitadores entre $10^{20}$ e $10^{21}$ dopantes. $\mathrm{cm}^{-3}$ estão de acordo com os obtidos por HAKIKI et al. em 1995 (aço 304 e ligas Fe-Cr), por MONTEMOR et al. em 2000 (316L e ligas de níquel) e por CASTRO E VILCHE em 1993 (Ligas de Fe e Fe-Cr).

Com relação ao aço AISI 444, a concentração de dopantes, na parte do filme óxido mais próximo ao substrato metálico (tipo-p), apresentou alta estabilidade entre 2 e 21 dias. As características do filme interno, descrito na literatura como fino e compacto (DA CUNHA BELO et al. 1998; MONTEMOR et al. 2000; HAKIKI et al. 1995), têm grande influência em sua resistência à corrosão. Segundo MILOSEV e STREHBLOW (2000), a camada interna, rica em $\mathrm{Cr}_{2} \mathrm{O}_{3}$, tem estequiometria aproximadamente constante em meios que favorecem a formação do filme passivo. Como o óxido de cromo é estável, a contribuição da condutividade eletrônica deste filme é um fator extremamente importante na resistência à corrosão do substrato metálico.

\subsection{Ensaios eletroquímicos em condição de fresta}

Na Figura 68 são apresentadas as medidas do potencial de circuito aberto para os aços ISO 5832-1 e AISI 444, em condição de fresta.

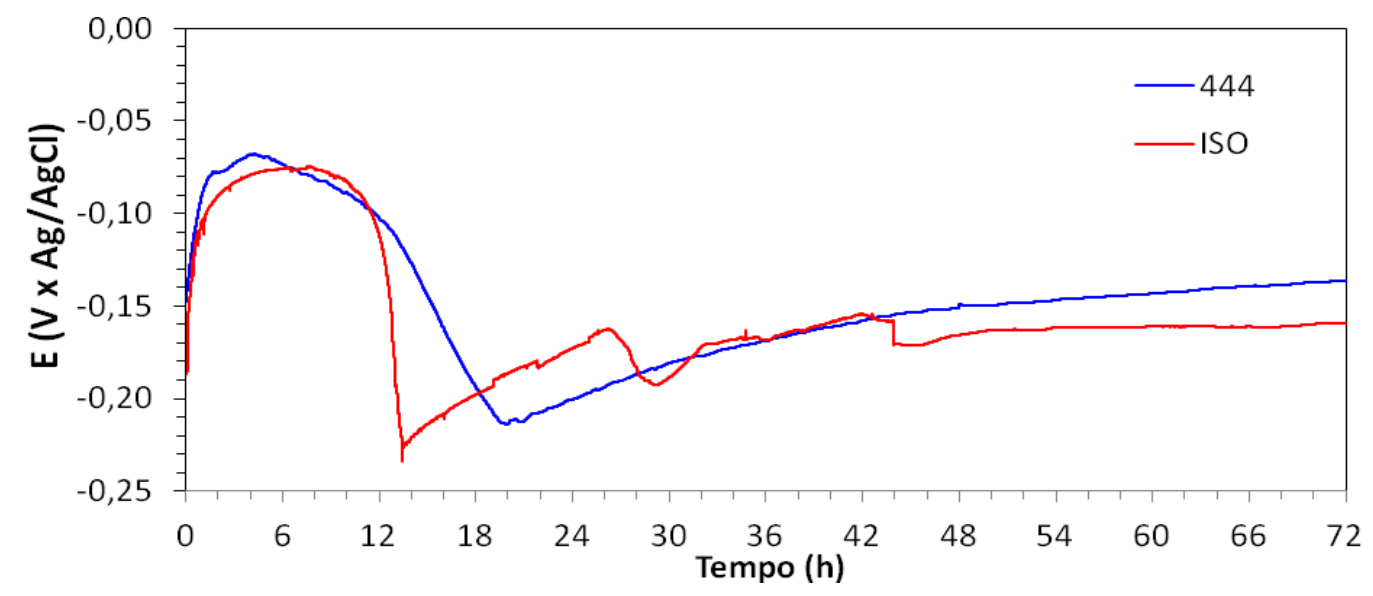

Figura 68 - Variação do potencial de circuito aberto para os aços ISO $5832-1$ e AISI 444, em condição de fresta, ao longo de 72 horas de imersão em solução PBS a $37^{\circ} \mathrm{C}$. 
As amostras foram polidas instantes antes de iniciar o ensaio, desta forma, buscou-se remover o filme óxido formado ao ambiente. O monitoramento do potencial de circuito aberto iniciou-se logo após o eletrólito de PBS ter sido inserido dentro da célula.

Conforme pode ser observado na Figura 68, nos momentos iniciais após a imersão, ocorreu um aumento contínuo do potencial até, aproximadamente, 6 h e relativa estabilização deste entre 6 h e 10 h. Após este período, os potenciais, de ambos os materiais, iniciaram uma queda até atingirem seu valor mais negativo, após $14 \mathrm{~h}$ para o aço ISO 5832-1 e em $20 \mathrm{~h}$ para o aço AISI 444. O aumento de potencial dos dois aços, observado logo após a imersão, ocorreu devido ao oxigênio dissolvido no meio, o qual promoveu o crescimento do filme. À medida que este se esgotou e não pôde ser reposto, ocorreu a formação de pilhas de aeração diferencial em algumas áreas do material exposto ao eletrólito. Isto causou o ataque do filme de óxido recém-formado, particularmente na região de fresta, resultando na redução do potencial.

O potencial medido representa o valor médio entre a região de fresta e a superfície exposta, esta última, com livre acesso ao oxigênio dissolvido no meio. $\mathrm{Na}$ superfície metálica exposta ao meio aerado, possivelmente, ocorreu uma recuperação lenta do filme óxido, sugerida pelo aumento subsequente no potencial, após atingirem o valor mais negativo. $\mathrm{O}$ aumento de potencial para 0 aço AISI 444 indicou um mecanismo de crescimento do óxido superficial mais uniforme do que para o aço ISO 5832-1, pois este último apresentou oscilações na curva, no período de crescimento do filme passivo (após $14 \mathrm{~h}$ de imersão). Para o aço AISI 444, tanto a cinética de formação do filme, como a de seu ataque, são mais lentas, indicando uma maior estabilidade da camada superficial.

Ao atingirem a estabilização no meio, os dois aços testados mostraram valores de potenciais muito próximos. Após 72 h, o aço AISI 444 estabilizou em aproximadamente $-140 \mathrm{mV}_{\mathrm{Ag} / \mathrm{AgCl}}$, enquanto o aço ISO 5832-1 em um potencial menos nobre, ao redor de $-160 \mathrm{mV}_{\mathrm{Ag} / \mathrm{AgCl}}$. Ambos os valores de potencial, na condição de estacionariedade, foram bem inferiores aos observados em condição de aeração livre, conforme o esperado.

Para investigar a possibilidade de ter ocorrido corrosão nos aços ISO 5832-1 e AISI 444, após 72 h de imersão, as superfícies destes aços foram observadas por MEV (Figura 69 e Figura 72, respectivamente). 


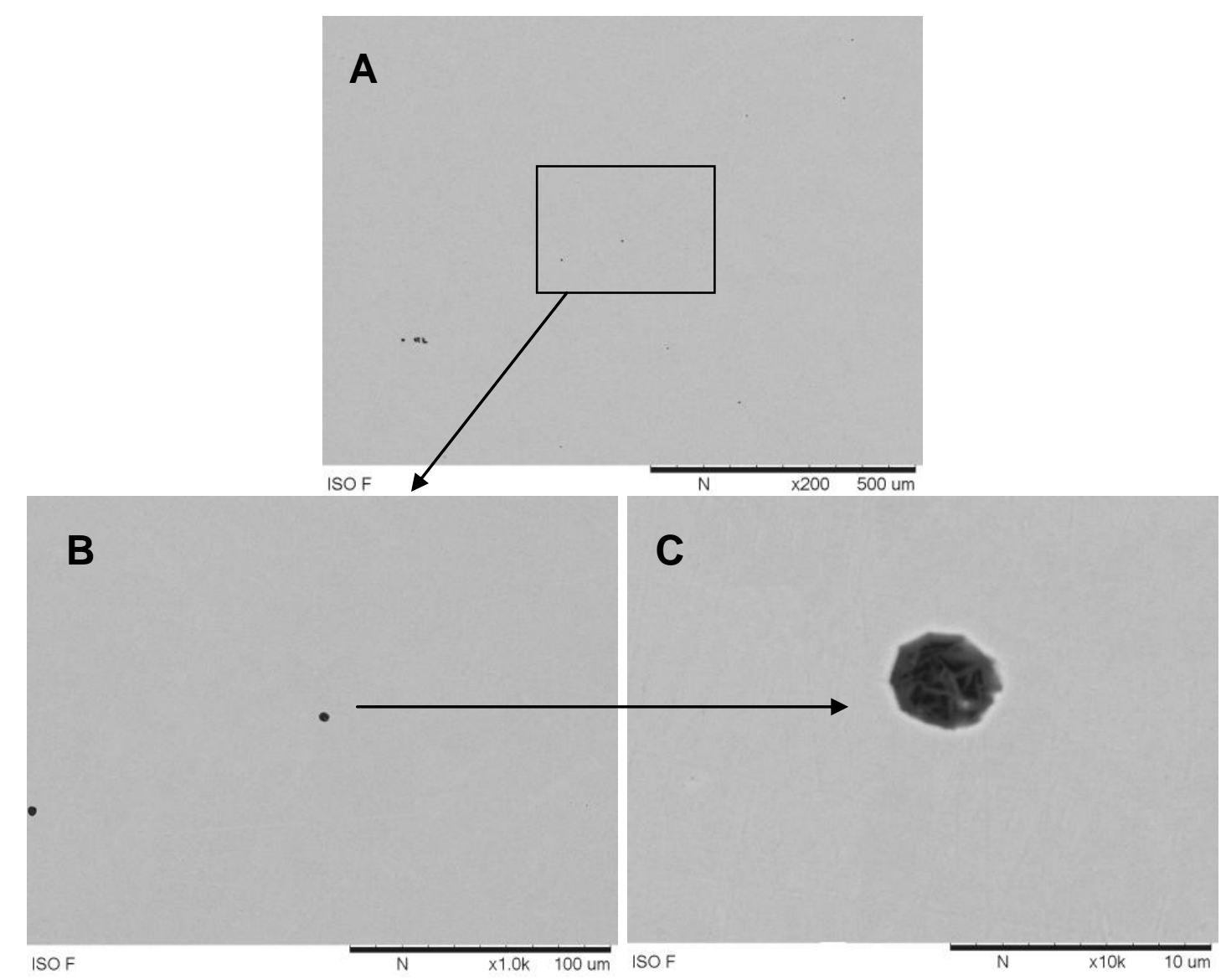

Figura 69 - Micrografias obtidas por MEV da superfície do aço ISO 5832-1, após 72 horas de imersão em solução PBS a $37^{\circ} \mathrm{C}$, em condição de fresta. A) Visão geral da amostra. B) Maior aumento da região em destaque. C) Maior aumento do ponto indicado pela seta.

Pôde-se observar na Figura 69A uma superfície muito similar ao material apenas polido (Figura 19A). Após varredura da amostra, foi possível verificar a presença de alguns pontos com formato geométrico regular (Figura 69B e C), os quais são sugestivos de pites. Para esclarecer se a micrografia da Figura $69 \mathrm{C}$ representa uma região de corrosão localizada por pite, uma amostra do aço ISO 5832-1, apenas polida, foi observada por MEV para comparação (Figura 70).

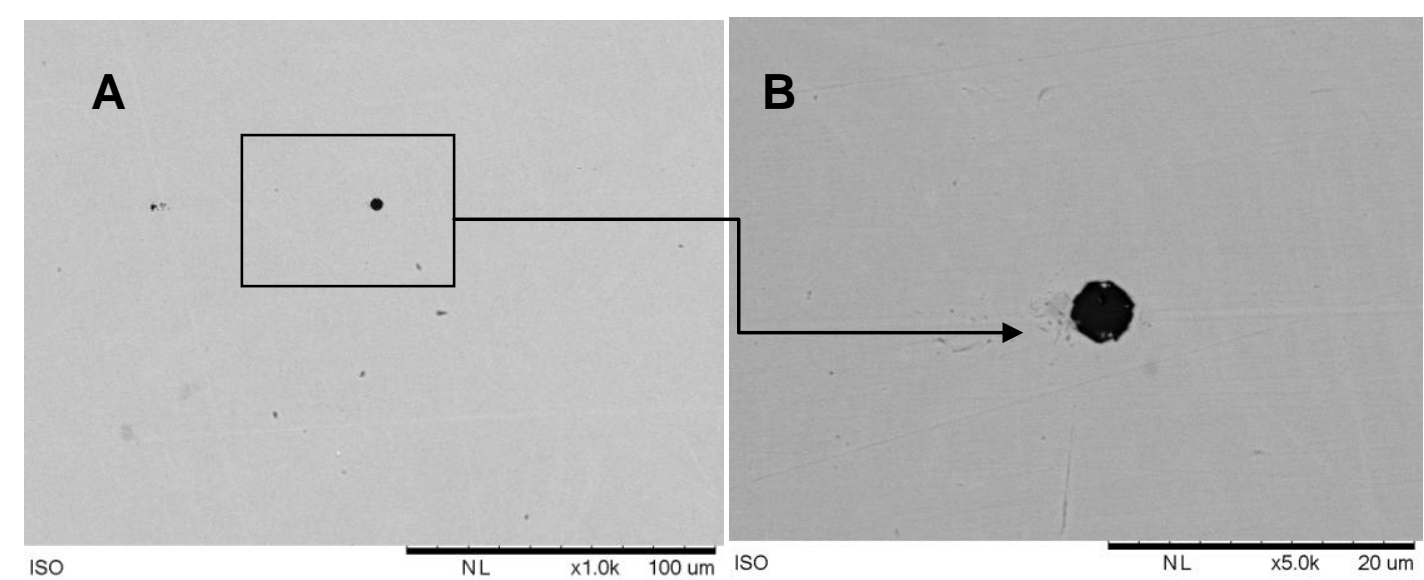

Figura 70 - MEV da superfície do aço ISO após polimento. A) Imagem similar ao encontrado na amostra polarizada. B) Maior aumento da área em destaque. 
As micrografias da Figura 70 mostraram similaridade às obtidas para a amostra, após 72 horas de imersão em condição de fresta (Figura 69B e C). Portanto, os pontos sugestivos de pite são inerentes ao próprio material. Utilizando um equipamento de alta resolução (FEl, modelo Quanta $650 \mathrm{FEG}$ ), foi possível identificar estas regiões mais escuras como inclusões com alto teor de alumínio e oxigênio, ou seja, alumina (Figura 71 e Tabela 15).

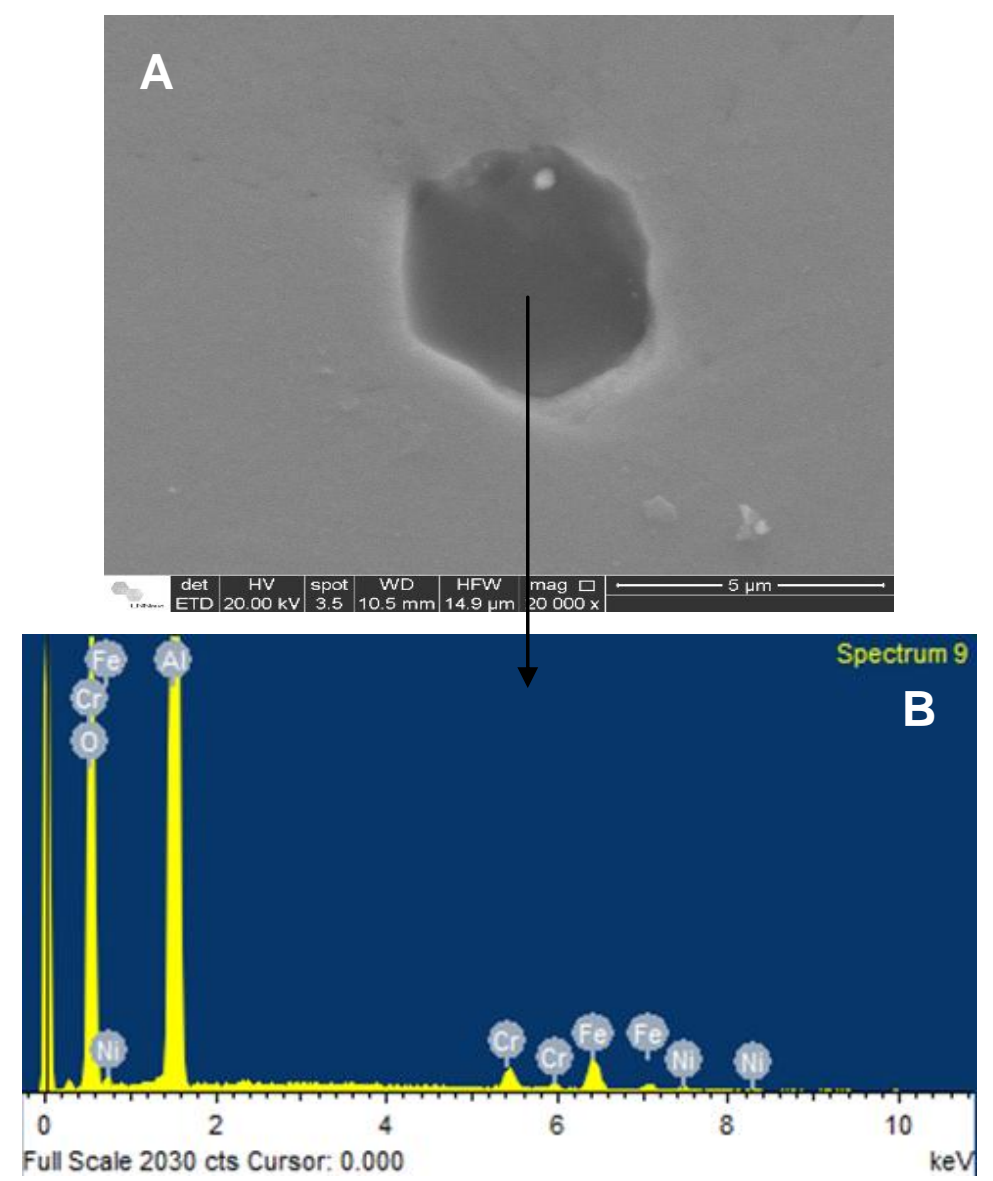

Figura 71 - MEV da superfície do aço ISO 5832-1 após polimento. A) Inclusão. B) EDS da inclusão.

Tabela 15 - Composição química semiquantitativa (EDS) dos principais elementos encontrados na inclusão da Figura 71 (\% em massa).

\begin{tabular}{ccccc}
\hline $\mathbf{C r}$ & $\mathbf{F e}$ & $\mathbf{A l}$ & $\mathbf{O}$ & $\mathbf{N i}$ \\
\hline 5,8 & 17,6 & 32,5 & 38,6 & 3,6 \\
\hline
\end{tabular}




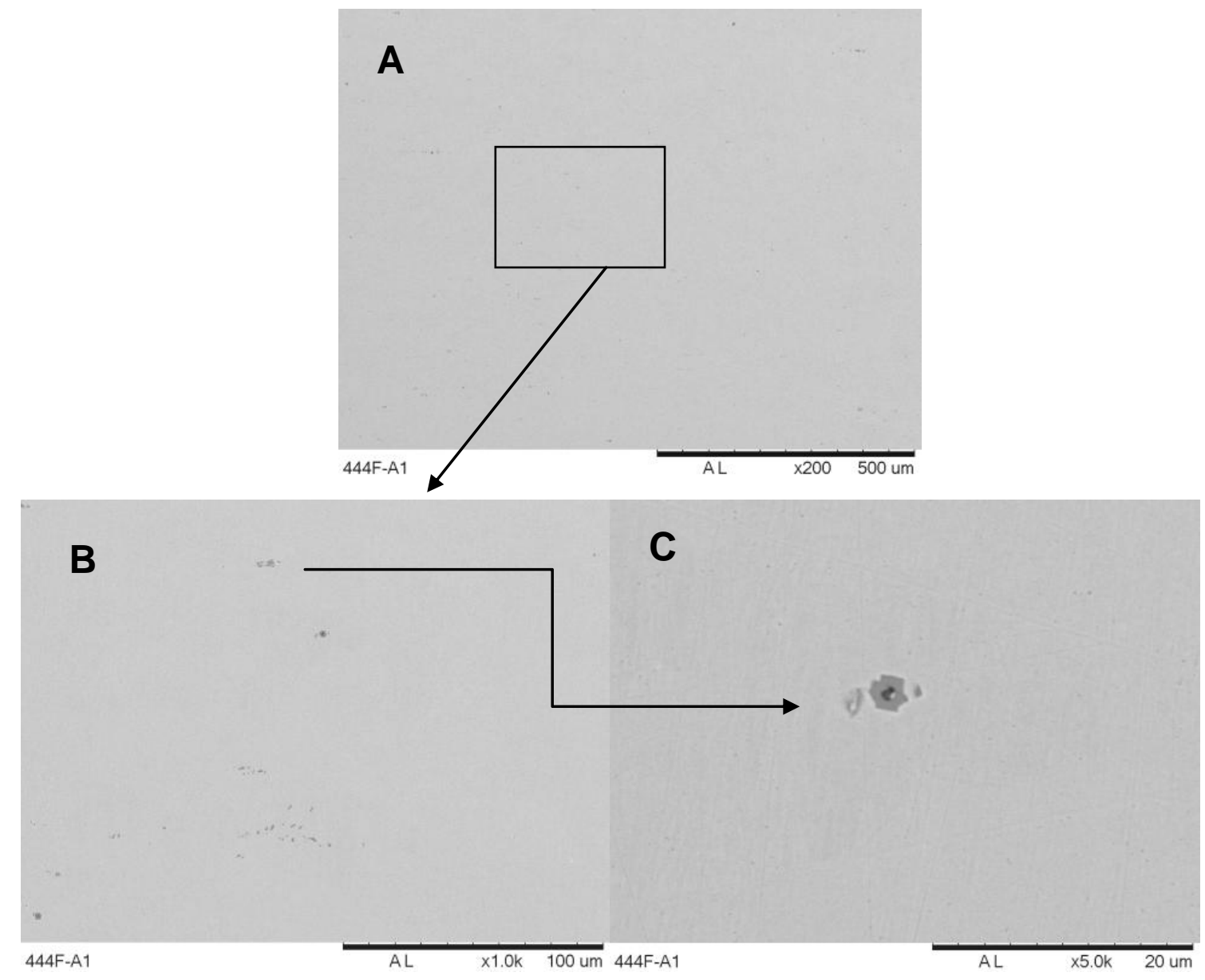

Figura 72 - Micrografias obtidas por MEV da superfície do aço AISI 444, após 72 horas de imersão em solução PBS a $37^{\circ} \mathrm{C}$, em condição de fresta. A) Visão geral da amostra. B) Maior aumento da região em destaque. C) Maior aumento do ponto indicado pela seta.

A micrografia da Figura $72 \mathrm{~A}$ para o aço AISI 444 revelou uma superfície homogênea, aparentemente isenta de pites e com pequenos pontos escuros. Estes pontos, observados em maior aumento nas Figura 72B e C, foram identificados como inclusões ricas em silício ou precipitados ricos em $\mathrm{Ti}$ e $\mathrm{Nb}$ inerentes à liga, conforme caracterização anterior no presente trabalho (Figuras 25, 26 e 27). Fez-se uma varredura na superfície da amostra e não foi encontrada nenhuma imagem sugestiva de corrosão localizada, na forma de pites. O aço AISI 444 aparentemente não sofreu ataque pelo meio de ensaio, mesmo em condição de fresta.

Os resultados do potencial de circuito aberto confirmaram que, após 48 horas, ambos os materiais estavam em condições de estacionariedade. Sendo assim, foram realizados os ensaios de espectroscopia de impedância eletroquímica, para 2 e 7 dias de imersão. 
A Figura 73 mostra os diagramas de Bode (A) e Nyquist (B) para os aços ISO 5832-1 e AISI 444, após 2 e 7 dias de imersão na solução PBS a $37^{\circ} \mathrm{C}$, em condição de fresta.
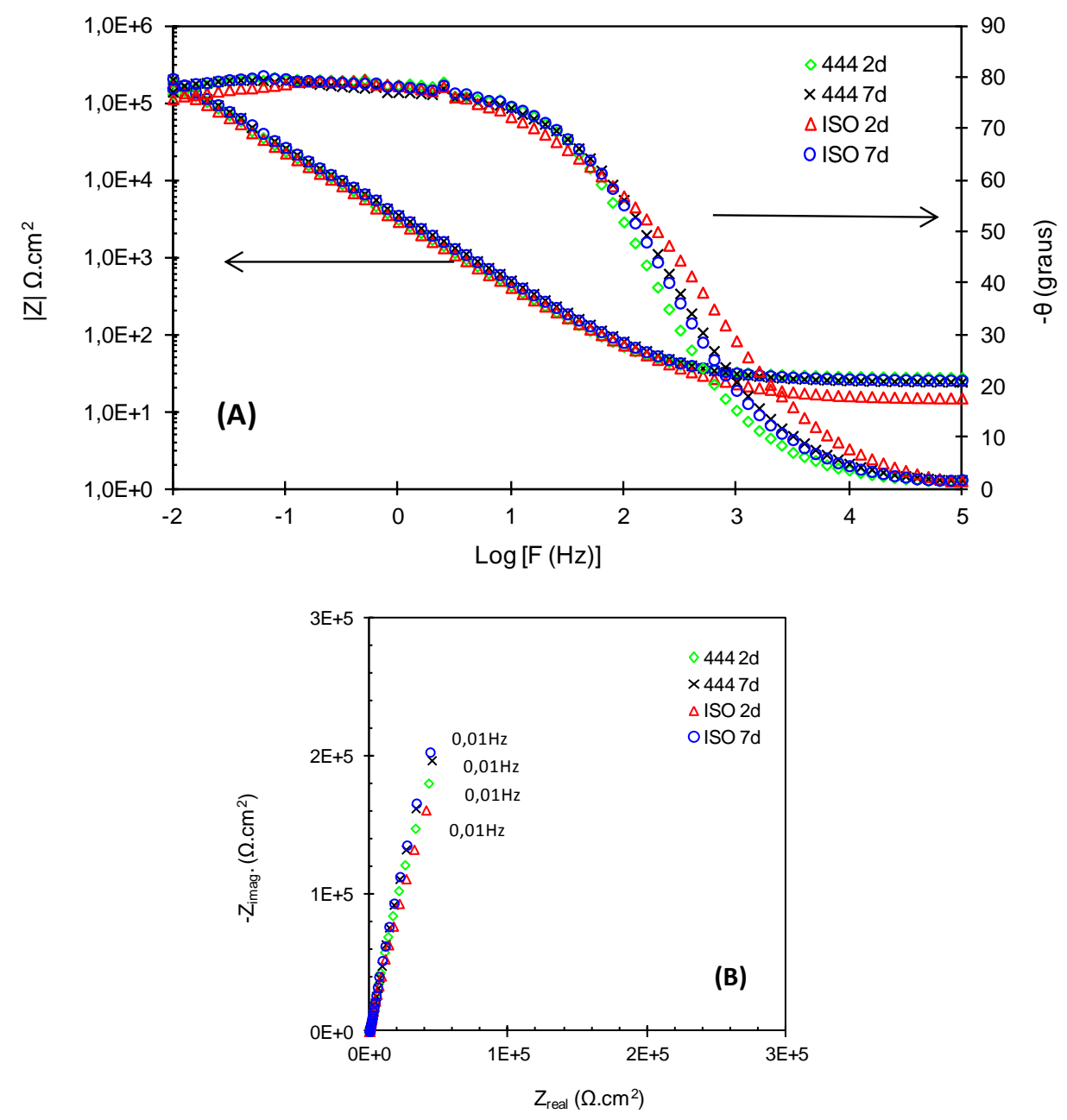

Figura 73 - Diagramas de Bode (A) e Nyquist (B) para os aços ISO 5832-1 e AISI 444 nos períodos de imersão de 2 e 7 dias em condição de fresta.

Os diagramas de Bode (Figura 73A) mostraram o aumento nos ângulos de fase com a diminuição da frequência até cerca de $10 \mathrm{~Hz}$. Para frequências menores, os ângulos de fase praticamente não variaram, desta forma teve-se a formação de um patamar. Isto indicou a sobreposição de mais de uma constante de tempo, entre $10 \mathrm{~Hz}$ e frequências mais baixas. Os diagramas de Nyquist (Figura 73B) revelaram que, tanto para o aço AISI 444 quanto para o ISO 5832-1, ocorreu aumento de impedância com o tempo de imersão entre 2 e 7 dias. Os altos valores de impedância e a similaridade dos diagramas de Bode, em diferentes períodos, foram explicados pela condição passiva dos dois aços no meio testado. 
Os diagramas de impedância foram ajustados pelo CEE da Figura 74 e os resultados são apresentados na Tabela 16. Os erros são mostrados no ANEXO II.

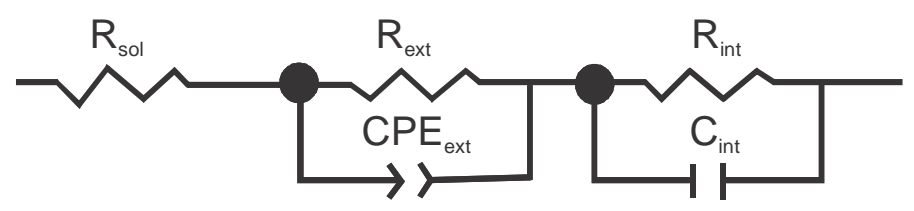

Figura 74 - Circuito elétrico equivalente proposto para caracterizar a camada passiva dos aços 444 e ISO, em condição de fresta.

Tabela 16 - Valores dos elementos dos circuitos elétricos equivalentes ajustados sobre os resultados de EIE dos aços ISO e 444, após 2 e 7 dias de imersão em meio PBS a $37^{\circ} \mathrm{C}$, em condição de fresta.

\begin{tabular}{l|c|c|c|c}
\hline & \multicolumn{2}{|c|}{ ISO } & \multicolumn{2}{c}{$\mathbf{4 4 4}$} \\
\hline & $\mathbf{2}$ dias & $\mathbf{7}$ dias & $\mathbf{2}$ dias & $\mathbf{7}$ dias \\
\hline $\mathbf{R}_{\text {sol }}\left(\Omega . \mathbf{c m}^{2}\right)$ & 15,09 & 26,04 & 28,35 & 24,74 \\
\hline $\mathbf{C P E}_{\text {ext }}\left(\mathbf{c m}^{-2} \mathbf{s}^{-n} \Omega\right)$ & $2,12 \times 10^{-4}$ & $1,56 \times 10^{-4}$ & $1,7 \times 10^{-4}$ & $1,5 \times 10^{-4}$ \\
\hline $\mathbf{n}_{\text {ext }}$ & 0,70 & 0,75 & 0,76 & 0,74 \\
\hline $\mathbf{R}_{\text {ext }}\left(\Omega . \mathbf{c m}^{2}\right)$ & $3,69 \times 10^{4}$ & $3,2 \times 10^{4}$ & $3,22 \times 10^{4}$ & $3,15 \times 10^{4}$ \\
\hline $\mathbf{C}_{\text {int }}\left(\mathbf{F} . \mathbf{c m}^{2}\right)$ & $9,31 \times 10^{-5}$ & $7,85 \times 10^{-5}$ & $8,94 \times 10^{-5}$ & $8,02 \times 10^{-5}$ \\
\hline $\mathbf{R}_{\text {int }}\left(\Omega . \mathbf{c m}^{2}\right)$ & $7,62 \times 10^{5}$ & $1,7 \times 10^{6}$ & $1,38 \times 10^{6}$ & $1,67 \times 10^{6}$ \\
\hline
\end{tabular}

Os valores dos parâmetros elétricos resultantes do ajuste do CEE quantificaram as observações já descritas nos diagramas de Nyquist e Bode. Os valores da $R_{\text {int, }}$ para ambos os aços, indicaram um aumento da impedância do sistema de 2 para 7 dias, e, consequentemente, maior resistência a transferência de cargas na interface metal/óxido.

Tabela 17 - Valores dos elementos dos circuitos elétricos equivalentes ajustados sobre os resultados de EIE dos aços ISO e 444, após 2 e 7 dias de imersão em meio PBS a $37^{\circ} \mathrm{C}$, em condição de fresta e aerada.

\begin{tabular}{l|c|c|c|c}
\hline & \multicolumn{2}{|c|}{ ISO } & \multicolumn{2}{c}{$\mathbf{4 4 4}$} \\
\hline & Aerado & Fresta & Aerado & Fresta \\
\hline $\mathbf{R}_{\text {sol }}\left(\Omega . \mathbf{c m}^{2}\right)$ & 19,26 & 15,09 & 13,71 & 28,35 \\
\hline $\mathbf{C P E}_{\text {ext }}\left(\mathbf{c m}^{-2} \mathbf{s}^{-\mathbf{n}} \Omega\right)$ & $1,39 \times 10^{-4}$ & $2,12 \times 10^{-4}$ & $1,21 \times 10^{-4}$ & $1,7 \times 10^{-4}$ \\
\hline $\mathbf{n}_{\text {ext }}$ & 0,78 & 0,70 & 0,77 & 0,76 \\
\hline $\mathbf{R}_{\text {ext }}\left(\Omega . \mathbf{c m}^{2}\right)$ & $1,82 \times 10^{4}$ & $3,69 \times 10^{4}$ & $1,91 \times 10^{4}$ & $3,22 \times 10^{4}$ \\
\hline $\mathbf{C}_{\text {int }}\left(\mathbf{F} . \mathbf{c m}^{2}\right)$ & $3,65 \times 10^{-5}$ & $9,31 \times 10^{-5}$ & $6,19 \times 10^{-5}$ & $8,94 \times 10^{-5}$ \\
\hline $\mathbf{R}_{\text {int }}\left(\Omega \cdot \mathbf{c m}^{2}\right)$ & $3,57 \times 10^{6}$ & $7,62 \times 10^{5}$ & $1,62 \times 10^{6}$ & $1,38 \times 10^{6}$ \\
\hline
\end{tabular}


Pelos resultados da Tabela 17, a resistência à polarização dos aços ISO 5832-1 e AISI 444 (soma de $R_{\text {ext }}$ e $R_{\text {int }}$ ) foi menor para condição de fresta, em comparação à condição de aeração livre. Este resultado era esperado, uma vez que a condição de fresta causa um maior ataque ao filme passivo. Este ataque provoca micro defeitos no mesmo que, consequentemente, facilitam a transferência de cargas (SATO, 1990).

Os valores de capacitância das interfaces $\left(\mathrm{CPE}_{\text {ext }}\right.$ e $\left.\mathrm{C}_{\text {int }}\right)$ indicaram um filme superficial mais espesso em meio aerado, para ambos os aços. Na condição de aeração livre, a camada passiva tem livre acesso ao oxigênio. Como os aços estão passivos no meio e há oxigênio sendo absorvido na interface óxido/eletrólito, pode ocorrer o crescimento do filme. Na condição de fresta, o filme óxido é mais facilmente atacado pelo meio corrosivo. Além disso, o reduzido acesso ao oxigênio dificulta o seu crescimento.

Visando avaliar a estabilidade do filme passivo e comparar a resistência dos óxidos formados sobre os dois materiais, foram realizados ensaios de polarização. Na Figura 75, são apresentadas as curvas de polarização anódica potenciodinâmicas cíclicas para os aços ISO 5832-1 e AISI 444, obtidas após 2 dias de imersão em condição de fresta.

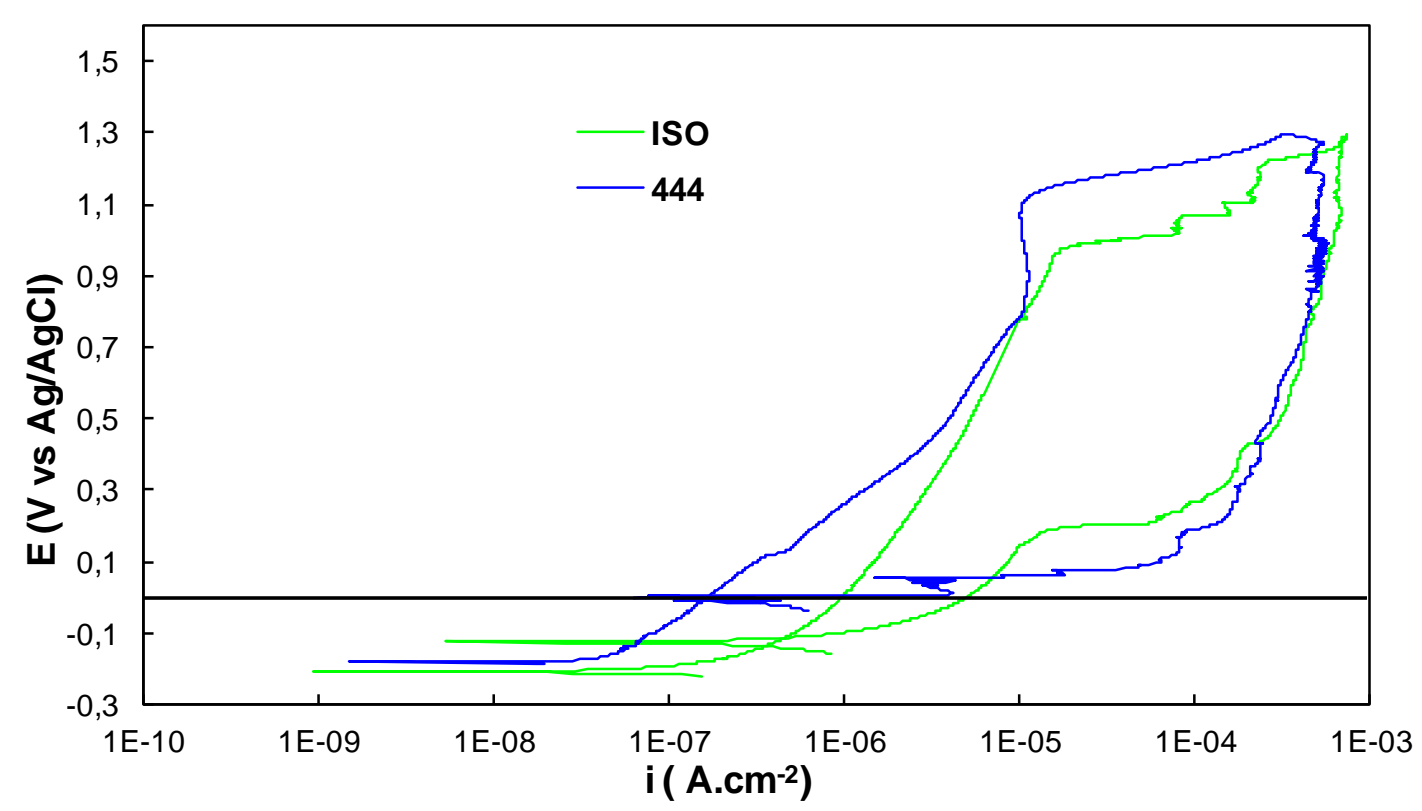

Figura 75 - Curvas de polarização anódica potenciodinâmica cíclica, após 2 dias de imersão em solução PBS a $37 \stackrel{\circ}{ } \mathrm{C}$, em condição de fresta.

As curvas de polarização anódicas, em condição de fresta (Figura 75), mostraram taxas de corrosão do aço AISI 444 menores que para o aço ISO 5832- 
1. O potencial que causou aumento na densidade de corrente, devido a quebra do filme, ocorreu em valores maiores para o aço AISI $444\left(\cong+1100 \mathrm{mV} \mathrm{mV} \mathrm{Agg}_{\mathrm{AgCl}}\right)$,

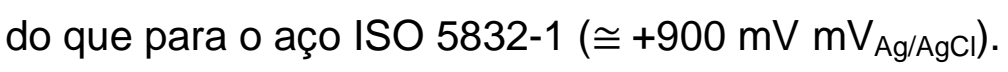

Considerando os elevados potenciais de quebra do filme passivo e a densidade de corrente de corrosão, ambos os materiais demonstraram elevada resistência ao ataque corrosivo em condição de fresta. Porém, as curvas sugeriram que o filme passivo sobre o aço AISI 444 foi mais protetor do que o sobre o aço ISO 5832-1, provavelmente, devido presença de inclusões de alumina neste último.

A superfície polarizada das amostras dos aços AISI 444 e ISO 5832-1, em condição de fresta, foram fotografadas e observadas por microscopia ótica (Figura 76).
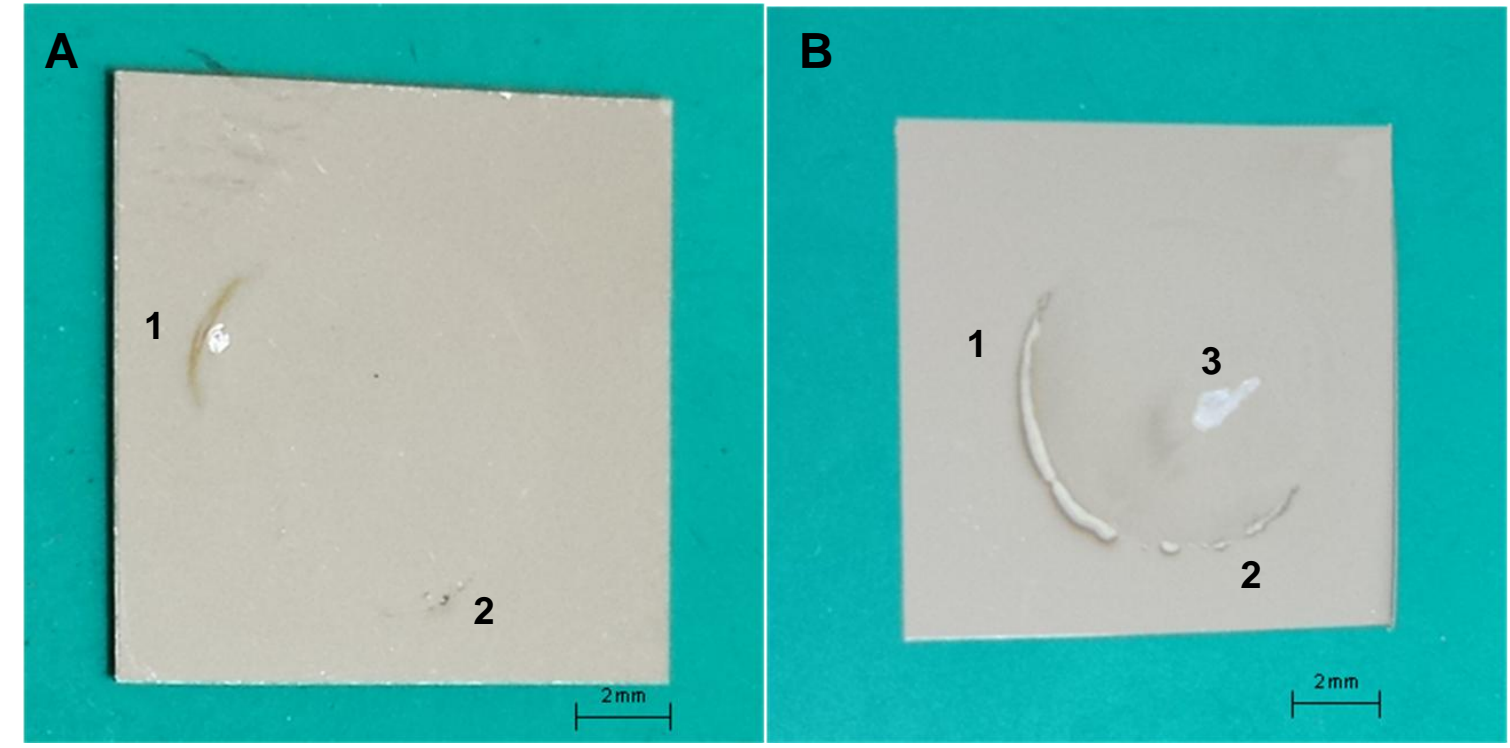

Figura 76 - Fotografias das amostras dos aços AISI 444 (A) e ISO 5832-1(B) após polarização anódica potenciodinâmica cíclica, com 2 dias de imersão em solução PBS naturalmente aerada a $37^{\circ} \mathrm{C}$, na condição de fresta.

A Figura 76A refere-se à superfície do aço AISI 444 após polarização. As áreas indicadas pelos números 1 e 2 mostraram regiões que sofreram corrosão. É importante observar que os dois pontos de corrosão ocorreram nas bordas da região de fresta. Para o aço ISO (Figura 76B), ficou evidente que ocorreu maior área de ataque corrosivo, tanto nas bordas da fresta (pontos 1 e 2) quanto no interior da mesma (ponto 3). 
As Figuras 77 e 78 apresenta ampliações das áreas indicadas na Figura 76A (pontos 1 e 2, respectivamente), mostrando com detalhes a morfologia do ataque corrosivo no aço AISI 444.

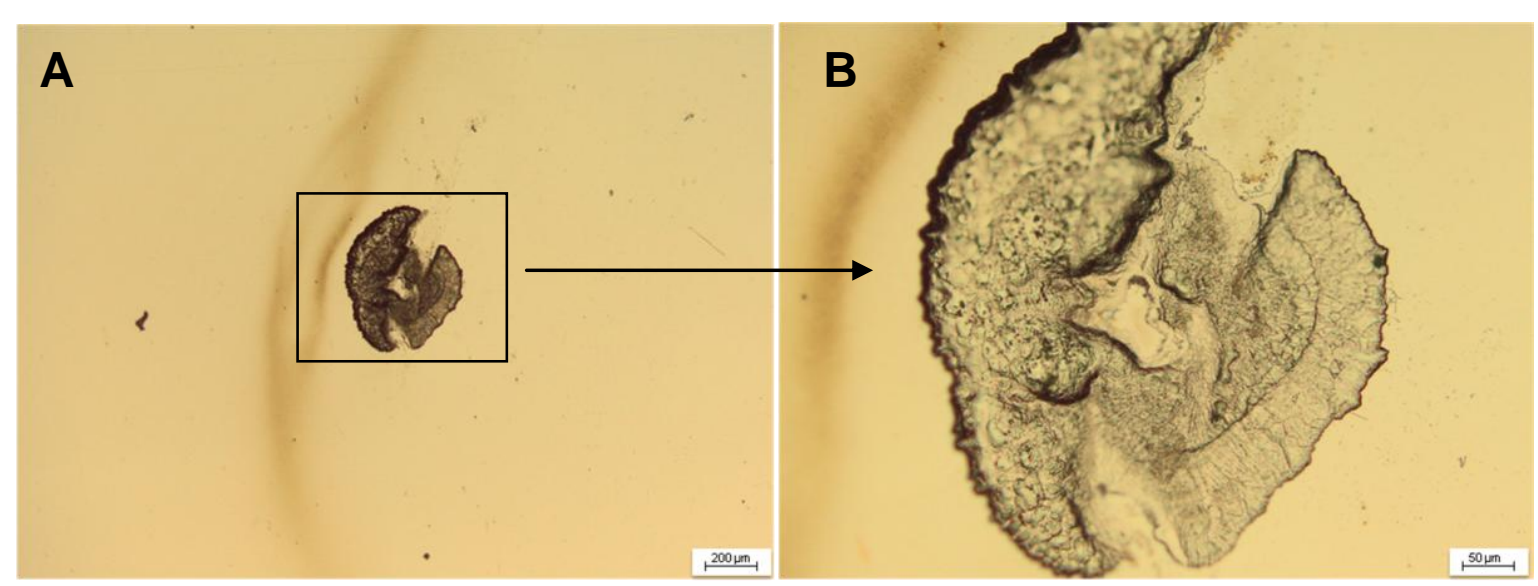

Figura 77 - Aço AISI 444 após polarização em condição de fresta. A) Corrosão localizada próxima à fresta (ponto 1 da Figura $76 \mathrm{~A}$ ) com diâmetro aproximado de 400 micras. B) MO com maior aumento da área selecionada.

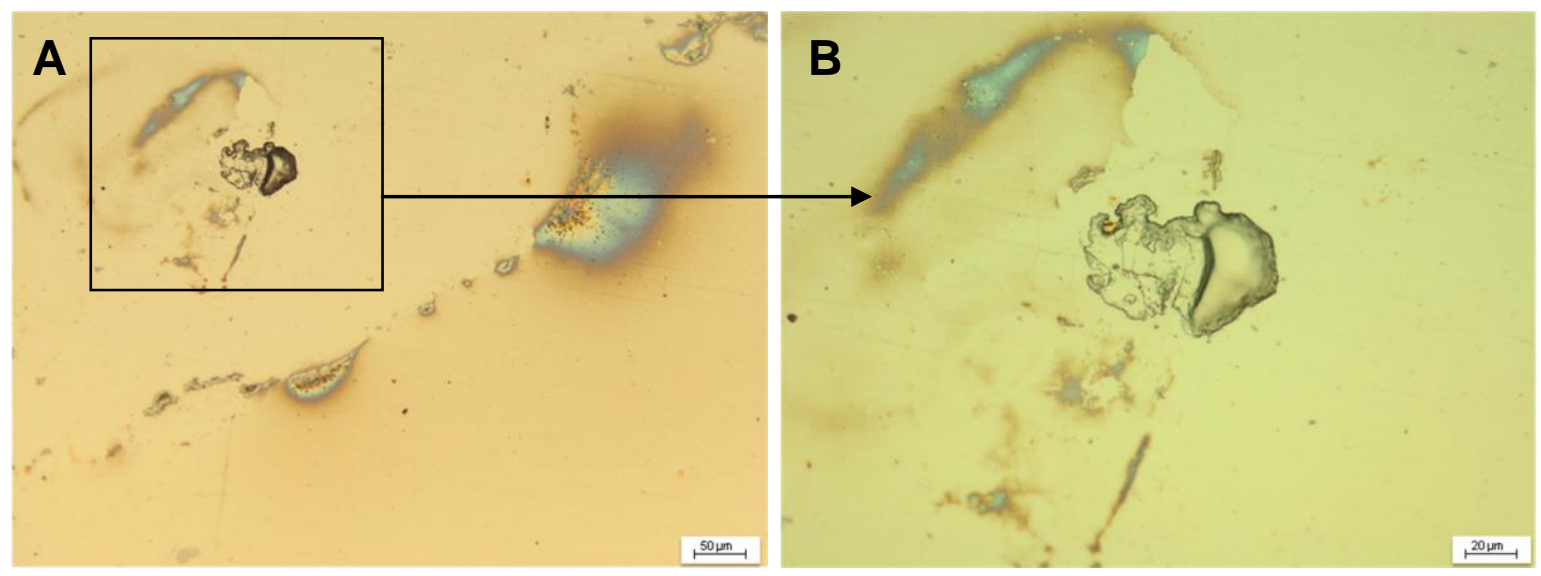

Figura 78 - Aço AISI 444 após polarização em condição de fresta. A) Corrosão localizada próxima à fresta (ponto 2 da Figura 76A) com comprimento aproximado de 70 micras. B) MO com maior aumento da área selecionada.

As Figuras 79 e 80 exibem as regiões de ataque do aço ISO 5832-1 polarizado, em condição de fresta. Assim como observado nas amostras de aço AISI 444, o ataque concentrou-se na região de maior diferença de aeração, entre a superfície exposta ao eletrólito e àquela com difícil acesso ao oxigênio, ou seja, a borda da fresta. 


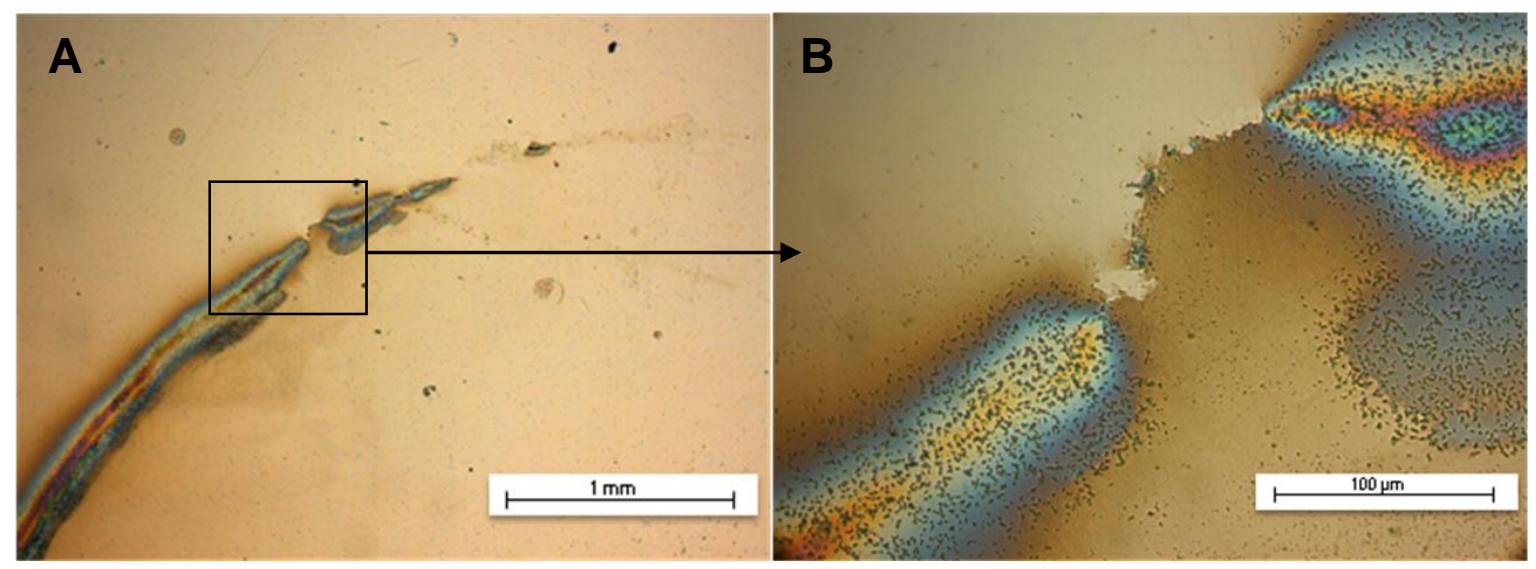

Figura 79 - Aço ISO 5832-1 após polarização em condição de fresta. A) Corrosão localizada (ponto 1 da Figura 76B), evidenciando a geometria da borda da fresta. B) MO com maior aumento da área selecionada.

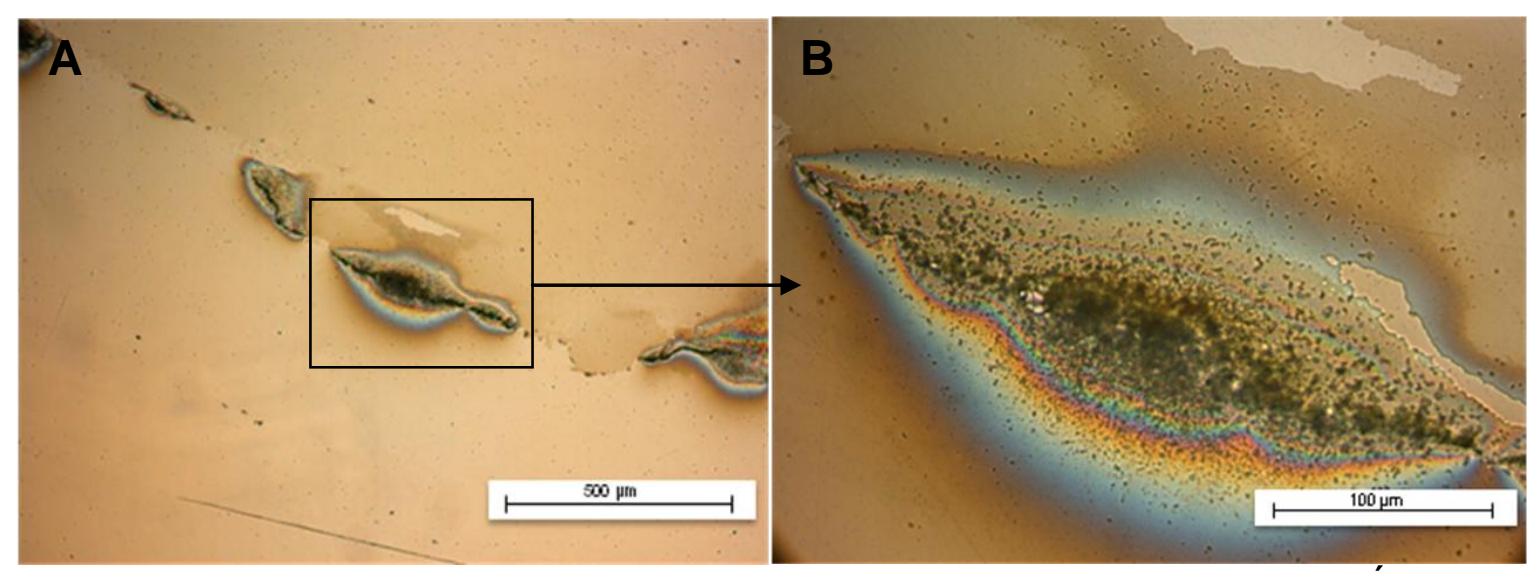

Figura 80 - Aço ISO 5832-1 após polarização em condição de fresta. A) Áreas de corrosão localizada (ponto 2 da Figura 76B) acompanhando a borda da fresta. B) MO com maior aumento da área selecionada, mostrando região de corrosão localizada com comprimento aproximado de 350 micras.

O centro da amostra do aço ISO (ponto 3 da Figura 76B), sofreu ataque corrosivo diferenciado, que acabou por revelar a microestrutura do material, conforme observado na Figura 81.

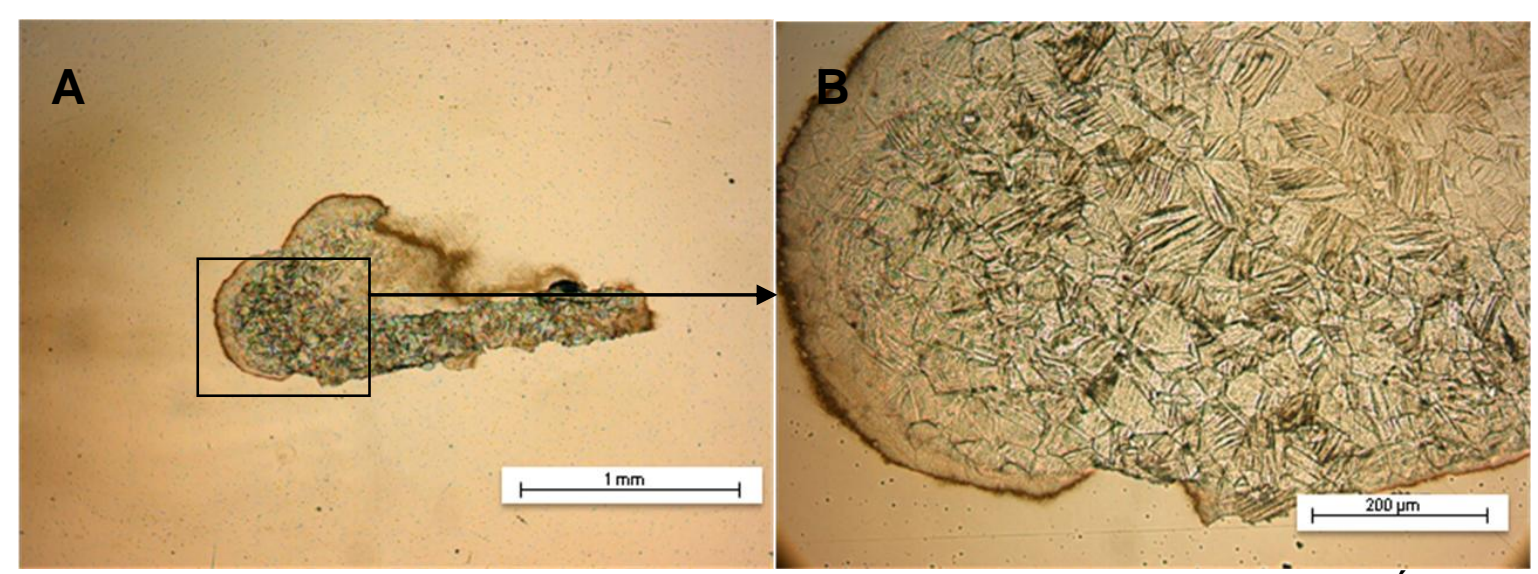

Figura 81 - Aço ISO 5832-1 após polarização em condição de fresta. A) Área de corrosão diferenciada no centro da amostra (ponto 3 da Figura 76B). B) MO com maior aumento da área selecionada. 
As regiões corroídas, nos aços AISI 444 e ISO 5382-1, concentraramse no limite entre a área oclusa (fresta) e o meio aerado. Esta mesma morfologia de ataque corrosivo em fresta foi observada por CHENG et al. em 2007 (Figura 8). A preferência pelo ataque corrosivo na borda da fresta foi devido à maior concentração de micropilhas por diferença de concentração. $\mathrm{O}_{2}$ foi consumido no interior da fresta, enquanto na região externa continua com alto teor. A queda na concentração de oxigênio, no interior da fresta, gerou uma diferença de potencial entre a solução aerada e o meio exterior, o que favoreceu a dissolução do metal $\left(\mathrm{Me} \rightarrow \mathrm{Me}^{+z}+\mathrm{ne}\right.$ ). Para equilibrar o excesso de íons $\mathrm{Me}^{+z}$, os cloretos $(\mathrm{Cl})$ migraram em direção à borda da fresta, formando um sal $\mathrm{Me}^{+z} \mathrm{Cl}^{-}$. O sal em contato com a água formou um hidróxido metálico $(\mathrm{MeOH})$ e ácido clorídrico $(\mathrm{HCl})$. Os elétrons da reação anódica reagiram com o oxigênio e a água, formando íons hidroxila $\left(\mathrm{O}_{2}+2 \mathrm{H}_{2} \mathrm{O}+4 \mathrm{e}^{-} \rightarrow 4 \mathrm{OH}^{-}\right)$. A diferença de cargas entre a região interna (anódica) e a externa (catódica), gerou um par galvânico, que acelerou o processo de corrosão, também agravado pela diminuição do pH local.

Devido à morfologia das regiões corroídas, após a polarização em fresta, ficou evidente que o aço ISO 5832-1 apresentou maior suscetibilidade a este tipo de corrosão, com maiores áreas afetadas (Figura 79) e maior profundidade de ataque (Figura 80). No centro da amostra, o filme passivo não foi capaz de conter o ataque corrosivo. As reações eletroquímicas da corrosão, em condição de fresta, criaram um meio altamente agressivo, o qual levou ao ataque do filme passivo e à revelação da microestrutura do aço ISO 5832-1 (Figura 81). Provavelmente, o ataque teve inicio nas regiões mais frágeis do filme passivo, como na interface entre as inclusões de alumina e a matriz. Após a quebra localizada do filme, o mesmo não foi capaz de se reestabelecer, permitindo a propagação de uma corrosão superficial, favorecida pela acidificação do meio. Isto possibilitou a observação da microestrutura austenítica e as maclas do aço ISO. Este ataque na região central da fresta foi observado em três amostras testadas do aço ISO 5832-1. 


\section{CONSIDERAÇÕES FINAIS}

Os resultados da análise química apresentado na Tabela 9, mostraram que o aço NeoM possui composição química que não atende à norma JIS para o aço SUS 444. O teor de $\operatorname{Cr}(13,2 \%)$ e de Mo $(0,34 \%)$ estão muito abaixo do requerido pela norma, ou seja, 17,5-19,5\% para o cromo e 1,75-2,50\% para o molibdênio. Na caracterização dos precipitados, não foi identificada a presença de $\mathrm{Ti}$ nem de $\mathrm{Nb}$, que deveriam ser encontrados em um aço estabilizado. Estes fatores, além da presença de grandes quantidades de MnS, podem justificar a menor resistência à corrosão do aço NeoM, indicada pelos ensaios eletroquímicos, em comparação aos demais aços utilizados. O aço NeoM apresentou os menores valores de impedância, maior suscetibilidade à corrosão por pite e maior condutividade eletrônica do óxido semicondutor tipo-p (camada interna do filme rica em cromo), o qual é o principal responsável pela resistência à corrosão dos aços inoxidáveis.

O papel dos íons cloretos, na suscetibilidade à corrosão por pite de diferentes ligas, tem sido amplamente investigado (BURSTEIN et al. 1993, WILLIAMS et al. 1985, WILLIAMS et al. 1985, FRANKEL et al. 1987). Os íons $\mathrm{Cl}^{-}$são adsorvidos e se acumulam na superfície do óxido, principalmente nas áreas de defeitos ou imperfeições, as quais, sendo menos espessas e resistentes, são preferencialmente rompidas durante o ensaio de polarização. Isto causa a quebra do filme passivo com o início e a propagação da corrosão por pite em aços inoxidáveis (LIN et al. 2010).

É bem aceito que o pite evolui, após a quebra localizada do filme passivo, devido à formação de micropilhas localizadas, nas quais as áreas passivas agem como catodo, enquanto as ativas, da superfície metálica exposta, como anodos (ANGELL et al. 1995, OLDFIELD e SUTTON 1978). A probabilidade de início da corrosão por pite em aços inoxidáveis é fortemente dependente da composição, densidade e tamanho das inclusões. Segundo SCHMUKI et al. (2005) e WILLIAMS et al. (1998), as reações eletroquímicas, na interface entre a inclusão e o metal base, são críticas para a estabilidade do aço contra corrosão. As inclusões de MnS são os defeitos mais propensos à corrosão por pite em solução contendo cloreto (LIN et al. 2010).

Segundo STEWART e WILLIAMS (1992), os pites nucleiam principalmente ao redor das inclusões de MnS. Este processo ocorre devido à dissolução, inicialmente predominante, na interface entre os precipitados de 
sulfeto e a matriz. Por baixo do precipitado, forma-se um meio ácido com alta concentração de sulfeto e cloreto. Neste meio o filme é instável, o que provoca o rompimento da camada passiva. Posteriormente, inicia-se a segunda fase da corrosão por pite, na qual o meio local é mantido como consequência da dissolução do aço em uma zona de difusão restrita (WILLIAMS et al. 1998)

Com base na importância das inclusões de MnS na nucleação da corrosão por pite, a presença de grande quantidade destas no aço NeoM teve importante contribuição na menor resistência à corrosão localizada, observada neste material.

A questão sobre como padronizar o contato sobre a amostra, para criar uma condição experimental de fresta, tem sido bastante discutida. Alguns autores propõem empregar um parafuso de torque, porém, não há um consenso sobre qual valor utilizar. Além disso, o torque não pôde ser relacionado com a força sobre a amostra e pode relaxar com o tempo, resultando em uma variação durante o teste (OLDFIELD,1989). Quando é utilizado um elástico, a pressão sobre a amostra não é padronizada, além de ocorrer afrouxamento durante o ensaio (CORBETT, 1992).

Não existe um acordo sobre a geometria da área oclusa, a qual varia de laboratório para laboratório e, até mesmo, durante o experimento (BRIGHAM, 1981). A região de fresta pode ser obtida por uma flange de PTFE (ABNT NBR 15613-4:2008 e ASTM - F746 - 04), um o-ring de Viton (PANOSSIAN et al., 2011), um cilindro de vidro (DAYAL et al., 1983), uma indentação (ASTM G 48-B), entre outros, sendo que, para cada proposta ocorre uma variação entre a área ativa e a passiva.

A ABNT possui apenas uma norma (NBR 15613-4:200) de ensaio para avaliar a corrosão, por pite ou por fresta, de implantes cirúrgicos metálicos. Esta proposta de avaliação indica a solução de PBS como meio de ensaio. A maior dificuldade da norma, sugerida pela ABNT, é conseguir confeccionar o eletrodo de trabalho dentro das especificações, uma vez que é necessário o material experimental na forma de um cilindro, o qual deverá ser usinado com precisão.

$\mathrm{O}$ equipamento desenvolvido nesta pesquisa objetivou simplificar a obtenção da condição de fresta. O cilindro do contra-corpo, que gera a superfície oclusa da fresta, foi feito em polímero de ultra alto peso molecular, pelos seguintes motivos: é um material já utilizado nas juntas de próteses de quadril, mais especificamente nos acetábulos; não forma par galvânico; não degrada na 
solução de ensaio; não risca a superfície da amostra; pode ser usinado em diferentes formatos, o que permite variar a geometria da fresta, se necessário. Os corpos de prova são embutidos em baquelite, ficando apenas uma face exposta ao meio, o que permite a avaliação do material experimental em quase todas as formas fornecidas. Além do que, como há apenas uma superfície plana de ensaio, é mais simples de calcular a área ativa da amostra. A pressão não varia durante o experimento, podendo, caso necessário, ser modificada com o acréscimo de carga sobre o suporte superior. O sistema de aquecimento é controlado automaticamente e a temperatura pode ser regulada de acordo com a proposta da pesquisa.

Com base nos dados obtidos, até o momento, o equipamento proposto para avaliação da resistência à corrosão, em condição de fresta, demostrou boa reprodutibilidade de resultados.

Pelos resultados obtidos, o aço utilizado na confecção da base ferromagnética (NeoM) não é indicado para uso como biomaterial, devido à sua baixa resistência à corrosão. Por outro lado, o aço inoxidável AISI 444 apresentou resistência à corrosão equivalente à do austenítico ISO 5832-1 e superior à do NeoM. Em condição de fresta, a resistência à corrosão do filme de óxido, formado sobre o aço AISI 444, foi superior à do ISO 5832-1. Com os resultados obtidos neste trabalho, conclui-se que o aço inoxidável AISI 444 apresentou alta potencialidade para uso como biomaterial, especialmente na fabricação de componentes protéticos com fixação magnética. 


\section{CONCLUSÕES}

Com base nos resultados obtidos, concluiu-se:

- O aço AISI 444 não apresentou citotoxicidade in vitro.

- A força de retenção magnética relativa, aferida no aço AISI 444, foi equivalente a do aço utilizado na fabricação do conector magnético (NeoM).

- O aço AISI 444 (como recebido ou solubilizado) apresentou-se passivo em solução PBS e sua resistência à corrosão foi similar à do ISO 5832-1, em condição de aeração natural.

- A solubilização não gerou melhora significativa na resistência a corrosão em célula aerada, conforme os resultados de polarização e EIE.

- A resistência à corrosão por pite do aço AISI 444, em condição de aeração natural, foi equivalente à do ISO 5832-1 e superior à do NeoM, ambos utilizados como materiais de referência.

- A análise química dos principais elementos de liga mostrou que o aço NeoM não está adequado à norma SUS 444, possuindo composição química fora da esperada. Os teores de $\mathrm{Cr}(13,2 \%)$ e de Mo $(0,34 \%)$ ficaram muito abaixo do requerido pela norma (17,5-19,5\% para o cromo e 1,75-2,50\% para o molibdênio). Não foram encontrados precipitados de $\mathrm{Ti}$ e $\mathrm{Nb}$, os quais deveriam estar presentes.

- O aço NeoM apresentou os menores valores de impedância, a maior suscetibilidade à corrosão por pite e a maior condutividade eletrônica do óxido semicondutor tipo-p (camada interna do filme rica em cromo), o qual é o principal responsável pela resistência à corrosão dos aços inoxidáveis.

- Os diagramas de Mott-Schottky indicaram que:

-Os filmes passivos sobre os aços AISI 444 e NeoM apresentaram caráter duplex. O óxido mais interno demonstrou características de um semicondutor tipo-p e o mais externo de um semicondutor do tipo-n. 
-O filme óxido sobre o aço AISI 444 apresentou menor concentração de dopantes que o do NeoM, sugerindo que o primeiro possui maior resistência à transferência de carga através dele.

- Com base nos ensaios de corrosão em condição de fresta, para os aços ISO 5832-1 e AISI 444, chegou-se as seguintes conclusões:

- Os aços AISI 444 e ISO 5832-1 não apresentaram indícios de corrosão localizada por pite, após $72 \mathrm{~h}$ de imersão no potencial de circuito aberto.

- Os diagramas de impedância confirmaram que ambos os materiais permaneceram em estado passivo, na condição de equilíbrio estacionário.

- As polarizações cíclicas pontenciodinâmicas indicaram baixas taxas de corrosão para ambos os aços, porém, maiores para o aço ISO 5832-1 em comparação ao aço AISI 444.

- A observação das superfícies dos aços, após a polarização, indicou maior ataque corrosivo no aço ISO 5832-1 do que no AISI 444.

- O equipamento desenvolvido para simular a condição de fresta apresentou boa reprodutibilidade, indicando ser uma ferramenta importante nesta pesquisa e em novas a serem desenvolvidas.

- O aço inoxidável AISI 444 apresentou alta potencialidade para uso como biomaterial, especialmente na fabricação de componentes protéticos com fixação magnética. 


\section{SUGESTÕES PARA TRABALHOS FUTUROS}

1) Estudo das correntes galvânicas geradas pelo par formado entre o aço AISI 444 e a liga de titânio CP grau IV.

2) Caracterização da composição química do filme óxido do aço AISI 444 por XPS, com e sem uso de desbaste iônico, na condição aerada e em fresta.

3) Investigação da morfologia do filme passivo por microscopia de força atômica (AFM).

4) Ensaios eletroquímicos em condição de fresta, usando meios fisiológicos simulados complexos, como MEM e Hanks.

5) Avaliar o equipamente desenvolvido para ensaios eletroquímicos, em condição de fresta, associado com o desgaste. 


\section{REFERÊNCIAS BIBLIOGRÁFICAS}

1802 datasheet. General datasheet of precison wire 1802, Sandivk, Suécia Disponível: $\quad$ http://www.smt.sandvik.com/pt/centro-de-materiais/datasheets-domaterial/wire/sandvik-1802/ Acessado em 31/03/2014.

ABREU, C. M., CRISTÓBAL, M. J., LOSADA, R., NÓVOA, X. R., PENA, G., PÉREZ, M. C., An insight on the role of Nickel in the passive films generated on different stainless steels, Passivation of Metals and Semiconductors, and Properties of Thin Oxide Layers. p. 29 -34, 2006.

ABREU, H.F.G.; HERCULANO, L.F.G.; MIRANDA, H.C.; TAVARES, S.S.M. Efeito da temperatura de recozimento na microestrutura em aços inoxidáveis ferríticos com alto teor de Mo. IN: XVII CBECIMAT- Congresso Brasileiro de Engenharia e Ciência dos Materiais, 2006, Foz do Iguaçu, PR, Brasil. XVII Congresso Brasileiro de Engenharia e Ciência dos Materiais, 2006. v. 1.

ABNT NBR 15613-4, Implantes para cirurgia - Resistência à corrosão Parte 4: Ensaio para corrosão por pite ou por fresta de materiais para implantes cirúrgicos metálicos. Associação Brasileira de Normas Técnicas, 2008.

AHN, S. J.; KWON, H. S., Effects of solution temperature on electronic properties of passive film formed on $\mathrm{Fe}$ in $\mathrm{pH} 8.5$ borate buffer solution, Electrochimica Acta, v. 49, p. 3347-3353, 2004.

AMERICAN SOCIETY FOR METALS. Metals Handbook. $10^{\mathrm{a}}$ ed. Metals Park, Ohio, ASM, v. 1, p. 841-907, 1990.

AMERICAN SOCIETY FOR TESTING AND MATERIALS. ASTM A240/A240M: Chromium and Chromium-Nickel Stainless Steel Plate, Sheet, and Strip for Pressure Vessels and for General Applications. Philadelphia, 2003.

ANGELL, P.; LUO, J.S.; WHITE, D.C. Microbially sustained pitting corrosion of 304 stainless steel in anaerobic seawater. Corr. Sci., v. 37, p. 1085-96, 1995.

ANTUNES, R. A. Caracterização do comportamento frente à corrosão de um aço inoxidável austenítico para aplicações biomédicas com revestimentos PVD de TiN, TiCN e DLC. 2006. Tese (doutorado) - Instituto de Pesquisas Energéticas e Nucleares. São Paulo, 2006.

ASSAMI, K.; HASHIMOTO, K. Importance of initial surface film in the degradation of stainless steels by atmospheric exposure. Corros Sci v. 45, p. 2263-83, 2003.

ASSIS, S. L. Investigação da resistência à corrosão da liga Ti-13Nb-13Zr por meio de técnicas eletroquímicas e de análise de superfície. Tese (doutorado). Instituto de Pesquisas Energéticas e Nucleares, São Paulo, 2006.

ASTM G48-03, Standard Test Methods for Pitting and Crevice Corrosion Resistance of Stainless Steels and Related Alloys by Use of Ferric Chloride Solution. ASTM International, West Conshohocken, PA, 2005 
AZUMI, K; OHTSUKA, T.; SATO, N. Impedance of iron electrode passivated in borate and phosphate solutions. Transactions of the Japan Institute of Metals, v. 27, n. 5, p. 382-392, 1986.

BAUTISTA, A., CENTENO, A. G., BLANCO, G., GUZMÁN, S., Application of EIS to the study of corrosion behaviour of sintered ferritic stainless steels before and after high-temperature exposure, Materials Characterization, v. 59,32- 39, 2008.

BOJINOV, M, BETOVA, I., FABRICIUS, G., LAITINEN, T., RAICHEFF, R., SAARIO, T. The stability of the passive state of iron-chromium alloys in sulphuric acid solution. Corrosion Science. v. 41, n. 8, p. 1557-1584, 1999.

BONORA, P. L.; DEFLORIAN, F.; FEDRIZZI, L. Electrochemical impedance spectroscopy as a tool for investigating underpaint corrosion. Electrochimica Acta, v. 41, n. 7-8, p. 1073-1082, 1996.

BOMBARA,G., CAVALLINI, M., Stress corrosion cracking of bone implants, Corrosion Science, v. 17, p. 77-85, 1977.

BOTTON, T. Estudo comparativo da resistência a corrosão em emio ácido e em meio contendo cloreto dos aços inoxidáveis UNS S44400, UNS S30403 e UNS S31603, obtidos por laminação à quente. Dissertação (Mestrado). Escola Politécnica da Universidade de São Paulo, São Paulo, 2008

BRANDIS, $\mathrm{H}$; KIESHEYER, $\mathrm{H}$. Influence of Chromium and Molybdenum on chloride Corrosion of Stainless Steels. In: Stainless Steels 84, Chalmers Univ. of Tech., Goteborg, Sweden, 3-4 Sept. 1984 The Institute of Metals; London; p. 217221, 1985.

BRIGHAM, R.J., Corrosion, v.30, n.11, p. 396, 1974.

BRIGHAM, R.J., Corrosion, v.37, n.10, p. 608, 1981.

BROWN, E.L., BURNETT M.E., PURTSCHER P.T., KRAUSS G., Intermetallic phase formation in $25 \mathrm{Cr}-3 \mathrm{Mo}-4 \mathrm{Ni}$ ferritic stainless steel, Metallurgical Transactions A, v. 14, p. 791-800, 1983.

BRUCE L. B.; ARLAN O. B. Metallographer's guide: practices and procedures for irons and steels / ASM Handbook, ASM International, p. 1-16, 2002

BRUNDLE, C. R.; EVANS, C. A.; WILSON, S., Encyclopedia of Materials Characterization, Butterworth-Heinemann, 1992

BUNDY, K. J.; DILLARD, J.; LUEDEMANN, R. Use of a.c. impedance methods to study the corrosion behaviour of implant alloys. Biomaterials. v.14, n. 7, p. 529-536, 1993.

BURSTEIN,G.T.; ISTOTIUS, P.C.; MATTIN, S.P. The nucleation and growth of corrosion pits on stainless steel. Corrosion Science, v.35, p.57-62, 1993.

CASTLE, J. E.; CLAYTON, C. R, The use of X-ray photo-electron spectroscopy in the analyses of passive layers on stainless steel, Corrosion Science, v. 17, p. 726, 1977. 
CASTRO, E. B; VILCHE, J. R. Investigation of passive layers on iron and ironchromium alloys by electrochemical impedance spectroscopy, Electrochimica Acta, v. 38, n. 11, p. 1567-1572, 1993.

CHIBA, A.; SAKAKURA, S.; KOBAYASHI, K.; KUSAYANAGI, K. Dissolution amounts of nickel, chromium and iron from SUS 304, 316 and 444 stainless steels in sodium chloride solutions. J Mater Sci, v.32, p.1995-2000, 1997.

CHUNG, R.W.C.; SIU, A.S.C.; CHU, F.C.S.; CHOW, T.W. Magnet-retained auricular prosthesis with an implant-supported composite bar: A clinical report. $\boldsymbol{J}$ Prosthet Dent, v. 89, p.446-9, 2003.

CIAPETTI, G.; GONZELEZ-CARRASCO, J.L.; SAVARINO, L.; MONTEALEGRE M.A.; PAGANI, S.; BALDINI, N. Quantitative assessment of the response of osteoblast- and macrophage- like cells to particles of ni-free fe-base alloys. Biomaterials, v. 26, p. 849-59, 2005.

CORBETT, R.A., Critical Crevice Corrosion Tests: Torque Retention Study. presented at the NACE T-5A-28 Task Group Meeting, Cincinnati, OH, 1991.

CORBETT, R.A., "Problems Utilizing ASTM G48 to Evaluate High Alloy Stainless Steels," Paper No. 298, NACE CORROSION/92 Conference, Abril 26 - Maio 1, Nashville, TN, 1992

DA CUNHA BELO, M.; WALLS, M.; HAKIKI, N. E.; CORSET, J.; PICQUENARD, E.; SAGON, G., NOËL, D. Composition, structure and properties of the oxide films formed on the stainless steel $316 \mathrm{~L}$ in a primary type PWR environment. Corrosion Science, v. 40, n. 2-3, p. 447-463, 1998.

DAVIS, D.M. et al. The extent of maintenance required by implant-retained mandibular overdentures: a 3-year report. International Journal of Oral and Maxilofacial Implants. Lombard. v. 11, p. 764-74, 1996.

DAVIS, G.O.; STREICHER, M.A., "Initiation of Chloride Crevice Corrosion on Stainless Alloys," Corrosion/85, paper no. 205 Boston, MA:NACE, 1985.

DAYAL, R.K.; PARVATHAVARTHINI, N.; GNANAMOORTHY, J.B. Measurement of Crevice Corrosion Resistance of Stainless Steels using a Potentiodynamic. Method British Corrosion Journal v.18, p. 184-86, 1983.

DEVGE, C.;TJELLSTRÖM, A.; NELLSTRÖM, H. Magnetic Resonance Imaging in patients with dental implants: a clinical report. The International Journal of Oral \& Maxillofacial Implants, v. 12, n. 3,p. 354-9, 1997.

DI PAOLA, A. Semiconducting properties of passive films on stainless steels. Electrochimica Acta, v. 34, n. 2, p. 203-210, 1989.

DOWLING, N.J.E.; KIM, Y.H.; AHN, S.K.; LEE, Y.D. Effect of alloying elements and residuals on corrosion resistance of type 444 stainless steel. Corrosion, v. 55, p. 187-99, 1999. 
Dyna Magnet Manual. Dyna Dental, Holanda - Disponível em: http://www.dynadental.com/editor/download-176/320504.01+Direct+System+brochure.pdf Acessado em 20/09/2011.

ELSTER, A.D.; BURDETTE, J.H. Questions \& answers in magnetic resonance imaging (2nd ed.), Mosby, St. Louis (2001).

FARIA, R.A. Efeito da Composição química de aços inoxidáveis ferríticos no desempenho de juntas soldadas pelo processo a arco metálico gasoso (SAMG), Dissertação (Mestrado), Escola Politécnica da Universidade de São Paulo. São Paulo, 2000

FEDERICK, D.R. A magnetically retained interim maxillary obturator. $\boldsymbol{J}$ Prosthet Dent, v. 36, p. 671-673, 1976.

FENG, Z.; CHENG, X.; DONG, C.; XU, L.; LI, X. Passivity of 316L stainless steel in borate buffer solution studied by Mott-Schottky analysis, atomic absorption spectrometry and X-ray photoelectron spectroscopy. Corrosion Science, v. 52, n. 11, p. 3646-3653, 2010.

FLORES M.S.; CIAPETTI, G.; GONZELEZ-CARRASCO, J.L.; MONTEALEGRE, M.A.; MULTIGNER, M.; PAGANI S. Evaluation of magnetic behaviour and in vitro biocompatibility of ferritic PM2000 alloy. J Mater Sci Mater Med, v. 15, n. 5, p. 559-565, 2004.

FOLKHARD, E. Welding metallurgy of stainless steels, Wien, New York: Springer-Verlag, p. 140-143, 1988.

FRANKEL, G.S.; STOCKERT, L.; HUNKELER, F.; BOEHNI, H. Metastable Pitting of Stainless Steel. Corrosion, v. 43, n. 7, p. 429-436, 1987.

FREDERICK, C.S.; DENG, F.L.; CHOW, T.W. Implant-tissue supported, magnetretained mandibular overdenture for an edentulous patient with Parkinson's disease: A clinical report J Prosthet Dent, v. 91, p. 219-222, 2004.

GE, H.; ZHOU, G.; WU, W. Passivation model of 316 stainless steel in simulated cooling water and the effect of sulfide on the passive film. Applied Surface Science, v. 211, n. 1-4, p. 321-334, 2003.

GENTIL, V. Corrosão. Rio de Janeiro: Editora Guanabara Dois, p. 432,1996.

GILLINGS, B.R.D. Magnetic retention for overdentures-Part II. J Prosthet Dent, v.49, p. 607-618, 1983.

GINESAN, P.; SMITH, G.D. Oxide scale formation on selected candidate combustor alloys in simulated gas turbine environments. Journal of Materials Engineering, v. 9, p. 337-343, 1988.

GIORDANI, E.J.; FERREIRA, I.; BALANCIN, O. Propriedades mecânicas e de corrosão de dois aços inoxidáveis austeníticos utilizados na fabricação de implantes ortopédicos. Rev. Esc. Minas [online], v. 60, n. 1, p. 55-62, 2007. 
GOPI, D., RAJESWARI, D., RAMYA, S., SEKAR. M., PRAMOD, R., DWIVEDI, J., KAVITHA, L., RAMASESHAN, R., Enhanced corrosion resistance of strontium hydroxyapatite coating on electron beam treated surgical grade stainless steel, Applied Surface Science, v. 286, p. 83-90, 2013.

GRANCHI, D.; CENNI, E., CIAPETTI, G.; SAVARINO, L.; STEA, S.; GAMBERINI, S.; GORI, A.; PIZZOFERRATO, A, Cell death induced by metal íons: necrosis or apoptosis? Journal of Materials Science: Materials in Medicine, v. 9, p. 31-37, 1998.

HACK, H.P. Galvanic in Corrosion tests and standards application and interpretation. ASTM Manual Series-MNL 20, p. 186-96, 1995.

HAKIKI, N. E.; DA CUNHA BELO, M. Semiconducting properties of passive films formed on stainless steels. Influence of the alloying elements. Journal of Electrochemical Society, v. 145, n. 11, p. 3821-3829, 1998.

HAKIKI, N.; BAUDIN, S.; RONDOT, B.; DA CUNHA BELO, M. The electronic structure of passive films formed on stainless steels. Corrosion Science, v. 37, n. 11 , p. $1809-1822,1995$

HANNINEN, H. ROMU, J.; ILOLA, R.; TERVO, J.; LAITINEN, A. Effects of processing and manufacturing of high nitrogen-containing stainless steels on their mechanical, corrosion and wear properties. Journal of Materials Processing Technology, v. 117, n. 3, p. 424-430, 2001.

HERTING, G.; WALLINDER I.O.; LEYGRAF C. Metal release from various grades of stainless steel exposed to synthetic body fluids. Corros Sci, v. 49, p. 103-11, 2007.

HIGHTON, R.; CAPUTO, A.A.; KINNI, M.; MATYAS, J. The interaction of a magnetically retained denture with osseointegrated implants. $J$ Prosthet Dent, v. 60, p. 486-90, 1988.

HIBNER E.L. "Evaluation of Test Procedures for Critical Crevice temperature Determination for Nickel Alloys in a Ferric Chloride Environment," Corrosion/86, paper no. 181, Houston, TX:NACE, 1986.

HIROMOTO, S.; NODA, K.; HANAWA, T. Development of electrolytic cell with cell-culture for metallic biomaterials. Corrosion Science, v. 44, n. 5, p. 955-965, 2002.

HOSOI, T.; OHKBUO, C.; TAKADA, Y; OKUNO, O.; NAKAMURA, Y.; TANAKA, Y.; ISHIGAMI, T.; UMEKAWA, Y.; KIKUCHI, A.; KINOUCHI, Y.; MIZUTANI, H. Foreign Dental Magnetic Attachments. The 7th International Conference on Magnetic Applications in Dentistry, Tokio, Japao, 2008.

IIMURO, F.T. Magnetic Resonance Artifacts and the Magnetic Attachment System. Dent Mat J, v. 13, n.1, p. 76-88, 1994.

ISO 10.993 - Biological evaluation of medical devices - part 5: Tests for cytotoxicity: in vitro methods, p. 1-7, 1992. 
JACOBS, J.; GILBERT, J.; URBAN, R. Current concepts review-Corrosion of metal orthopaedic implants. J Bone Joint Surg. v. 80, p. 268-282, 1998.

JANSEN, J.A.; RECUM, A.F. von; WAERDEN, J.P.C.M. van der; GROOT, K de. Soft tissue response to different types of sintered metal fibre-web materials. Biomaterials, v, 13, p. 959-68, 1992.

KERNS, J.R. In: BABOIAN, R. Corrosion tests and standards: Application and interpretation. ASTM, Philadelphia, USA, p.175-85 1995.

KITSUGI, A.; OKUMO, O.; NAKANO, T; HAMANAKA, H.; KURODA, T. The corrosion behavior of NdFeB and Sm Co Magnets. Dent Mat J, v. 11, n. 2, p. 11929, 1992.

KOIKE, M.; TAKADA, Y.; OKUNO, O.; OKABE, T. Corrosion Characteristics of Dental Magnetic Attachments. Em: 7th International Conference on Magnetic Applications in Dentistry, 2008, Tokyo. The Japanese Society of Magnetic Applications in Dentistry. Disponível em: http://wwwsoc.nii.ac.jp/jmd/international/7th/S005/

KOLCHAKOV, J., TZVETKOFF, T., BOJINOV, M., In situ and ex situ characterisation of the passive film on a ferritic stainless steel in molten sodium hydroxide, Applied Surface Science, v. 249, p. 162-175, 2005.

LIN, B.; HU,R.; YE,C.; LI, Y.; LIN, C. A study on the initiation of pitting corrosion in carbon steel in chloride-containing media using scanning electrochemical probes. Electrochim. Acta, v.55, p.6542, 2010.

LIU, C.; Bi, Q.; LEYLAND, A.; MATTHEWS, A. An electrochemical impedance spectroscopy study of the corrosion behaviour of PVD coated steels in $0.5 \mathrm{~N} \mathrm{NaCl}$ aqueous solution: Part I. Establishment of equivalent circuits for EIS data modeling. Corrosion Science, v. 45, n. 6, p.1243-1256, 2003.

LOVRECEK, B.; SEFAJA, J. Semiconducting aspects of the passive layer on chromium, Electrochimica Acta, v. 17, p. 1151-1155, 1972.

MALHEIRO, V.N.; SPEAR, R.L.; BROOKS, R.A.; MARKAKI, A.E. Osteoblast and monocyte responses to 444 ferritic stainless steel intended for a magnetomechanically actuated fibrous scaffold. Biomaterials, v. 32 , n. 29 , p. 6883-92, 2011.

MANSFELD, F.; SHIH, H. Detection of pitting with electrochemical impedance spectroscopy. Journal of the Electrochemical Society: Electrochemical Science and Technology, v. 138, n. 5, p. 1171-1172, 1988.

MARQUES, R.A. Estudo de materiais alternativos para a aplicação em sistemas de próteses odontológicas com conexões magnéticas. 2009, Dissertação (mestrado) - Instituto de Pesquisas Energéticas e Nucleares. São Paulo, 2009.

MARTINI, E. M. A.; MULLER, I. L. Characterization of the film formed on iron in borate solution by electrochemical impedance spectroscopy. Corrosion Science, v. 42, n. 3, p. 443-454, 2000. 
MEARS, D.C. Metals in medicine and surgery. International Metal Reviews, review 218, p. 119-155, 1997.

MEHDIPOUR, M., AFSHAR, A., MOHEBALI, M., Electrophoretic deposition of bioactive glass coating on $316 \mathrm{~L}$ stainless steel and electrochemical behavior study, Applied Surface Science, v. 258, p. 9832-9839, 2012.

MILOSEV, I. Effect of complexing agents o the electrochemical behavior of orthopaedic stainless steel in physiological solution. Journal of Applied Electrochemistry, v. 32, p. 311-320, 2002.

MILOSEV, I.; STREHBLOW, $\mathrm{H}-\mathrm{H}$. The behaviour of stainless steels in physiological solution containing complexing agent studied by X-ray photoelectron spectroscopy. Journal of Biomedical Materials Research, v. 52, n. 2, p. 404412, 2000.

MODENESI, P.J. Soldabilidade dos Aços Inoxidáveis. SENAI-SP, São Paulo, Brasil, v.1, 2001.

MONTEMOR, M.F.; FERREIRA, M.G.S.; HAKIKI, N.E.; DA CUNHA BELO, M. Chemical composition and electronic structure of the oxide films formed on 316L stainless steel and nickel based alloys in high temperature aqueous environments. Corrosion Science, v. 42, p. 1635-1650, 2000.

MORGENFELD, J. Los Nuevos Aceros Inxodables Ferriticos de Extra Bajos Intersticiales (EBI) y su Soldadura. Argentina, , p. 273-296, 1983.

MUDALI, U.K.; DAYAL, RK; Influence of nitrogen addition on the crevice corrosion resistance of nitrogen-bearing austenitic stainless steels. Journal Of Materials Science, 2000, Vol. 35 ,Iss. 7 , pp. 1799- 1803.

NAGASWAMI, N.S.; STREICHER, M.A. "Accelerated Laboratory Tests for Crevice Corrosion of Stainless Alloys," Corrosion/83, paper no. 71, (Anaheim, CA:NACE, 1983).

NAKAMURA K.; TAKADA, Y.; YODA, M.; KIMURA, K.; OKUNO, O. Galvanic corrosion of ferritic stainless steels used for dental magnetic attachments in contact with an iron-platinum magnet. Dent Mater J, v.27, p. 203-210, 2008.

NEW, P.F.J.; ROSEN, B.R.; BRADY, T.J.; BUONANNO, F.S.; KISTLER, J.P.; BURT, C.T.; HINSHAW, W.S.; NEWHOUSE, J.H.; POHOST, G.M.; TAVERAS, J.M. Potential hazards and artifacts of ferromagnetic and nanoferromagnetic surgical and dental materials and devices in Nuclear Resonance Imaging. Radiology, v. 147, p. 139-148, 1983.

OLDFIELD, J.W., "Effect of Crevice Geometry on the Corrosion of AISI 304 and 316 in Marine Environments," Corrosion/89, paper no. 290, New Orleans, LA, NACE, 1989.

OLDFIELD, J.W.; SUTTON, W.H. Crevice corrosion of stainless steel. Br. Corros. J., v.13, p. 13-22, 1978. 
OGUZIE, E.E., LI, J., LIU, Y., CHEN, D., Li, Y., YANG, K., WANG, F., The effect of $\mathrm{Cu}$ addition on the electrochemical corrosion and passivation behavior of stainless steels, Electrochimica Acta, v. 55, p. 5028-5035, 2010.

OH, K.T.; KIM, Y.S.; PARK, Y.S.; KIM, K.N. Properties of super stainless steels for orthodontic applications. J Biomed Mater Res B Appl Biomater, v. 69B, p. 18394, 2004.

OKUNO, O.; TAKADA, Y.; KIKUCHI, M.; KIMURA, K. Corrosion Resistance of Magnetic Stainless Steel Keeper for Dental Magnetic Attachment. Em: The First International Conference on Magnetic Applications in Dentistry, 2002, Tokyo. The Japanese Society of Magnetic Applications in Dentistry. Disponível em: http://wwwsoc.nii.ac.jp/jmd/international/1st/poster20i.shtml?20

ORÉFICE, R. L.; PEREIRA, M. M.; MANSUR, H. S. Biomateriais Fundamentos e Aplicações. Cultura Médica, p.1-58, p.185-531, 2006.

PADILHA, A. F. Aços Inoxidáveis Austeníticos. São Paulo - 1994

PAN, J.; KARLEN, C.; ULFVIN, C. Electrochemical study of resistance to localized corrosion of stainless steels for biomaterial applications. Journal of Electrochemical Society, v. 147, p. 1021-1025, 2000.

PANOSSIAN, Z.; PECEQUILO, C.V.; ALMEIDA, N.L.; PIMENTA, G.S. Performance evaluation of AISI 316L and super duplex AISI F53 stainless steels regarding crevice corrosion. In: 18th International Corrosion Congress, 2011, Perth. 18th International Corrosion Congress, 2011.

PÉREZ, F.J.; HIERRO, M.P.; GOMEZ, C.; MARTINEZ, L.; VIGURI, P.G. Ion implantation as a surface modification technique to improve localised corrosion of different stainless steels, Surface and Coatings Technology, v. 155, p. 250-259, 2002.

PICKERING, F.B. Physical metallurgy of stainless steel developments. International metals reviews, n. 21, p. 227-268, 1976.

POLO, J. L.; CANO, E.; BASTIDAS, J. M. An impedance study on the influence of molybdenum in stainless steel pitting corrosion. Journal of Electroanalytical Chemistry, v. 537, n. 1-2, p. 183-187, 2002.

RECLARU, L.; BROOKS, R.A.; ZUBERBÜLER, M.; ESCHLER, P.-Y.; CONSTANTIN, F.; TOMOAIA, G. Evaluation of taper joints with combined fatigue and crevice corrosion testing: Comparison to human explanted modular prostheses. Materials Science and Engineering: C v.34, p. 69-77, 2014.

ROGERO S.O.; SAIKI, M.; COSTA, I. Citotoxicidade de ligas metálicas utilizadas como biomateriais. Em: LATINCORR- Congresso Latino Americano de Corrosão, 2006, Fortaleza, Brasil, CD Rom (2006)

ROGERO, S.O.; LUGAO, A.B.; IKEDA, T.I.; CRUZ, A.S., Teste in vitro de citotoxicidade: estudo comparativo entre duas metodologias. Materials Research, v. 6, p. 317-320, 2003. 
RONDELLI, G. ; TORRICELLI, P. ; FINI, M. ; GIARDINO, R. In vitro corrosion study by EIS of a nickel-free stainless steel for orthopedic applications. Biomaterials, v. 26, n. 7, p. 739-744, 2005.

ROSSEL, C.M. Development of a cast, cathodically modified superferritic stainless steel for sulphuric acid applications. In: Stainless Steel World 1999 Conference. Anais. Holanda, 1999. p. 655-665.

SATO, N. An overview on the passivity of metals. Corrosion Science, v. 31, p. 119, 1990.

SAYGILI, G.; SAHMALI, S. Retentive forces of two magnetic systems compared with two precision attachments. J Oral Sci, v. 40, n. 2, p. 61-4, 1998.

SCHMUKI, P.; BÖHNI, H. Metastable Pitting and Semiconductive Properties of Passive Films. J Electrochem Soc, v. 139, n.7, p. 1908-1913, 1992.

SCHMUKI, P.; HILDEBRAND, H.; FRIEDRICH, A.; VIRTANEN, S. The composition of the boundary region of MnS inclusions in stainless steel and its relevance in triggering pitting corrosion, Corros. Sci., v.47, p.1239-50, 2005.

SCHULTZE, J.W.; LOHRENGEL, M.M. Stability, reactivity and breakdown of passive films. Problems of recent and future research. Electrochimica Acta, v. 45, p. 2499-2513, 2000.

SEDRIKS, A.J. Corrosion of stainless steels. 2.ed. New York, John Wiley. 1996. p. $1-4$; p. 35-47; p. 367-372; p.13-24; 102-175; p. 79-92; p. 360-387.

SHELLOCK, F.G.; CRUES, J.V. High field strength MR imaging and metallic biomedical implants: An ex vivo evaluation of deflection forces. Am. J. Roentgenol. v.151, p.389-392, 1988.

SHELLOCK, F.G.; MORISOLI, S.; KANAL, E. MR Procedures and Biomedical Implants, Materials, and Devices: Update. Radiology. v.189, p.587-599, 1993.

SHELLOCK, F.G.; MINK, J.H; CURTIN, S; FRIESMAN, M.J. MR imaging and metallic implants for anterior cruciate ligament reconstruction: Assessment of ferromagnetism and artifact. J. Magn. Reson. Imaging. v.2, p.225-228, 1992.

SHELLOCK, F.G. Biomedical implants and devices: Assessment of magnetic field interactions with a 3.0 tesla MR system. J. Magn. Reson. Imaging., v.16 p.721732, 2002.

SHAHRYARI, A.; OMANOVIC, S. Improvement of pitting corrosion resistance of a biomedical grade $316 \mathrm{LVM}$ stainless steel by electrochemical modification of the passive film semiconducting properties. Electrochemistry Communications, v. 9, n. 1, p. 76-82, 2007.

STEWART, J.; WILLIAMS, D.E. The initiation of pitting corrosion on austenitic stainless steel: on the role and importance of sulphide inclusions. Corros. Sci., v.33, p.457, 1992.

STREICHER, M. A., CORROSION, v.30, 3, p. 77, 1974 
SUMITA, M.; IKADA, Y.; TATEISHI T. Metallic Biomaterials-Fundamentals and Applications, ICP, Tokyo (2000), p. 629.

SUN, X.L.; ITO, A.; TATEISHI, T.; HOSHINO, A. Fretting corrosion resistance and fretting corrosion product cytocompatibility of ferritic stainless steel. $\boldsymbol{J}$ Biomed Mater Res, v. 34, p. 9-14, 1997.

TAVARES, S.S.M.; SOUZA, J.A.; HERCULANO, L.F.G.; ABREU, H.F.G., SOUZA Jr, C. M., Microstructural, magnetic and mechanical property changes in na AISI 444 stainless steel aged in the $560^{\circ} \mathrm{C}$ to $800^{\circ} \mathrm{C}$ range, Materials Characterization, v. 59, p. $112-116,2008$.

TAKADA, Y.; NAKAMURA, K.; KIMURA, K.; OKUNO, O. Corrosion behaviour of the stainless steel composing dental magnetic attachments. Int Congress Ser, v. 1284, p. 314-315, 2005

TAKADA, Y.; TAKAHASHI, N.; OKUNO O. Electrochemical behavior and released ions of the stainless steels used for dental magnetic attachments. Em: 6th International Conference on Magnetic Applications in Dentistry, 2007, Tokyo. The Japanese Society of Magnetic Applications in Dentistry. Disponível em: http://wwwsoc.nii.ac.jp/jmd/international/6th/S011/

TAVEIRA, L.V.; DALLA CORTE, D.A.; DICK, L.F.P. Area Effects on the MottSchottky Behavior of Anodic Films Formed on AISI 304 Stainless Steel. ECS transactions, v. 25, p. 17-22, 2010.

TAVEIRA, L.V.; MONTEMOR, M.F.; DA CUNHA BELO, M.; FERREIRA, M.G.; DICK, L.F.P. Influence of incorporated $\mathrm{Mo}$ and $\mathrm{Nb}$ on the Mott Schottky behaviour of anodic films formed on AISI 304L. Corrosion Science, v. 52, p. 2813-2818, 2010.

TERADA, M. Corrosão de aços inoxidáveis avançados em meios fisiológicos. 2008. Tese (doutorado) - Instituto de Pesquisas Energéticas e Nucleares. São Paulo, 2008.

THOMAS, C.R.; ROBINSON, F.P.A. Kinetics and mechanism of grain growth during welding in niobium stabilized $17 \%$ chromium stainless steels. Metals technology, v. 5, n .4, p.133-138, 1978.

THOMAS, K.F. Freestanding magnetic retention for extraoral prosthesis with osseointegrated implants. J Prosthet Dent, v. 73, p. 162-5, 1995.

TRESEDER, R.S. MTI Manual No. 3: Guideline Information on Newer Wrought Iron-and Nickel-Base Corrosion Resistant Alloys. Materials Technology Institute of the Chemical Process Industries. Columbus, OH, p.19, 1980.

VILLAMIL, R.F.V.; ARANHA, H.; AFONSO, M.L.; MERCADANTE, M.T.; AGOSTINHO, S.M.L. Aços inoxidáveis em implantes ortopédicos: fundamentos e resistência à corrosão. Revista Brasileira de ortopedia, v. 37, n.11/12, p. 471-476, 2002.

WALMSLEY, A.D. Magnetic Retention in Prosthetic Dentistry. Dent. Update, v. 29, p. 428-33, 2002. 
WATANABE I, TANAKA Y, OHKUBO C, MILLER AW. Application of cast magnetic attachments to sectional complete dentures for a patient with microstomia: A clinical report. J Prosthet Dent, v.88, n.6, p.573-7, 2002.

WRANGLÉN, G. Pitting and sulphide inclusions in steel. Corrosion Science, v. 14 , p. 331 a 349,1974

WILLIAMS, D.F. Implantable prostheses. Physics in Medicine and Biology, v. 25, n. 4, p. 611-636, 1980.

WILLIAMS, D.F. Review: Tissue-biomaterial interactions. Journal of Materials Science, v. 22, n. 11, p. 3421-3445, 1987.

WILLIAMS, D.E.; MOHIUDDIN, T.F.; ZHU, Y.Y. Elucidation of a trigger mechanism for pitting corrosion of stainless steels using submicron resolution scanning electrochemical and photoelectrochemical microscopy. J. Electrochem. Soc. v.145, p.2664, 1998.

WILLIAMS, D.E.; WESTCOTT, C.; FLEISHMANN, M. J. Stochastic Models of Pitting Corrosion of Stainless Steels: I . Modeling of the Initiation and Growth of Pits at Constant Potential. Electrochem. Soc., v.132, n.8, p.1796-1804, 1985.

WILLIAMS, D.E.; WESTCOTT, C.; FLEISHMANN, M. J. Stochastic Models of Pitting Corrosion of Stainless Steels: II . Measurement and Interpretation of Data at Constant Potential. Electrochem. Soc., v.132, n.8, p.1804-1811, 1985.

WOLYNEC, S. Técnicas eletroquímicas em corrosão. EDUSP, São Paulo, 2003.

WOODS, T.O. Stainless steels for medical and surgical applications. In: ASTM Symposium, EUA, p. 82-90, 2002.

World Biomedical Metal Market. Acmite Market Intelligence, Fevereiro, 2010. Disponível em: http://www.acmite.com/brochure/Brochure-Biomedical-MetalMarket-Report.pdf 


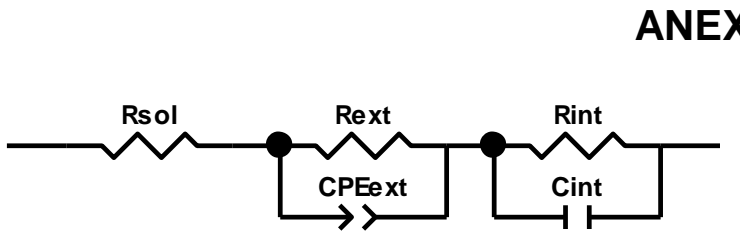

$\begin{array}{lllll}\text { Element } & \text { Freedom } & \text { Value } & \text { Error } & \text { Error } \% \\ \text { Rsol } & \text { Free }(+) & 13,71 & 0,077761 & 0,56718 \\ \text { Rext } & \text { Fixed }(X) & 19166 & \text { N/A } & \text { N/A } \\ \text { CPEext-T } & \text { Free }(+) & 0,0001217 & 2,2506 \mathrm{E}-06 & 1,8493 \\ \text { CPEext-P } & \text { Free }(+) & 0,77587 & 0,0027835 & 0,35876 \\ \text { Rint } & \text { Free }(+) & 1,6273 E 06 & 1,5715 \mathrm{E} 05 & 9,6571 \\ \text { Cint } & \text { Free }(+) & 6,1934 \mathrm{E}-05 & 4,4619 \mathrm{E}-07 & 0,72043\end{array}$

Chi-Squared:

0,0028649

Weighted Sum of Squares: $\quad 0,3925$

Data File:

C:IUsers $\backslash$ RogeriolDocuments $\backslash$ Doutorado $\backslash$ Resultados

Circuit Model File:

Mode:

C: $\mid$ Users $\backslash$ Rogerio $\backslash$ Documents $\backslash$ DoutoradolResultados

Maximum Iterations:

Run Fitting / Freq. Range (0,001 - 1000000)

100

Optimization Iterations:

Type of Fitting:

Complex

Type of Weighting:

Calc-Modulus
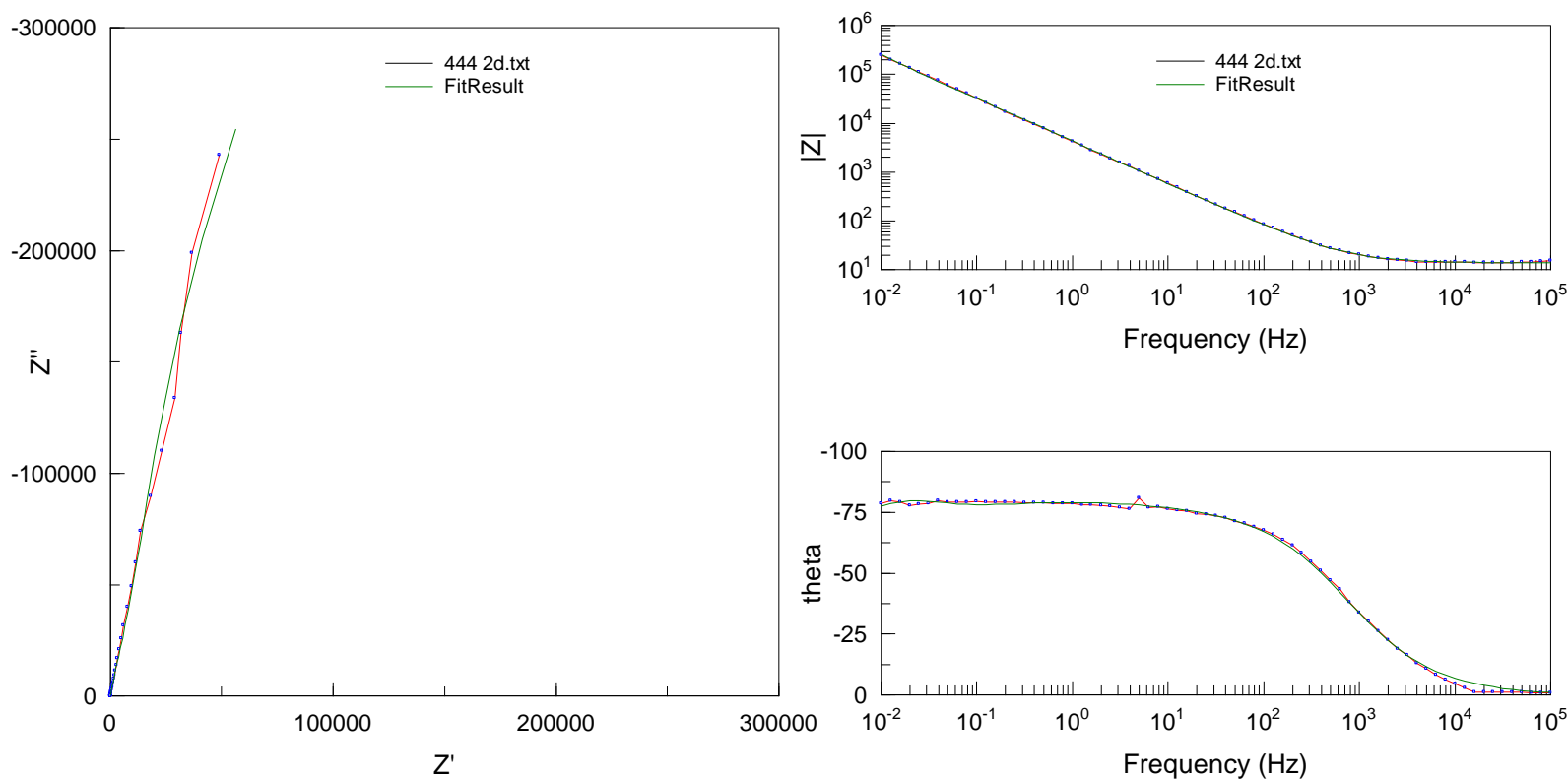

Ajustes dos diagramas de impedância pelo CEE para o aço AISI 444, após 2 dias de imersão em solução PBS a $37^{\circ} \mathrm{C}$. 


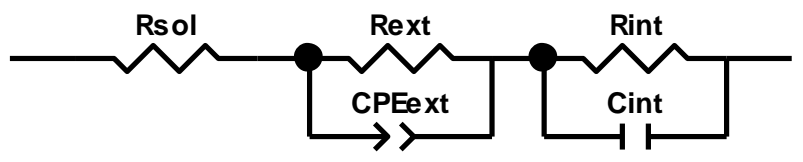

\begin{tabular}{|c|c|c|c|c|}
\hline Element & Freedom & $\underline{\text { Value }}$ & Error & Error \% \\
\hline Rsol & Free $(+)$ & 13,34 & 0,1315 & 0,98576 \\
\hline Rext & Free $(+)$ & 6069 & 516,48 & 8,5101 \\
\hline CPEext-T & Free $(+)$ & $9,4223 \mathrm{E}-05$ & 1,1965E-06 & 1,2699 \\
\hline CPEext-P & Fixed $(X)$ & 0,7777 & $\mathrm{~N} / \mathrm{A}$ & $\mathrm{N} / \mathrm{A}$ \\
\hline Rint & Free(+) & $1,0103 \mathrm{E} 06$ & 91685 & 9,075 \\
\hline Cint & Free $(+)$ & 5,3894E-05 & $7,1388 \mathrm{E}-07$ & 1,3246 \\
\hline
\end{tabular}

Chi-Squared: $\quad 0,0078825$

Weighted Sum of Squares: $\quad 1,0799$

Data File: $\quad$ C:IUsers $\backslash$ Rogerio $\quad$ Documents $\backslash$ DoutoradolResultados

Circuit Model File: $\quad$ C:IUsers $\backslash$ Rogerio $\quad$ Documents $\backslash$ DoutoradolResultados

Mode: $\quad$ Run Fitting / Freq. Range $(0,001-1000000)$

Maximum Iterations: $\quad 100$

Optimization Iterations: $\quad 0$

Type of Fitting: Complex

Type of Weighting: Calc-Modulus
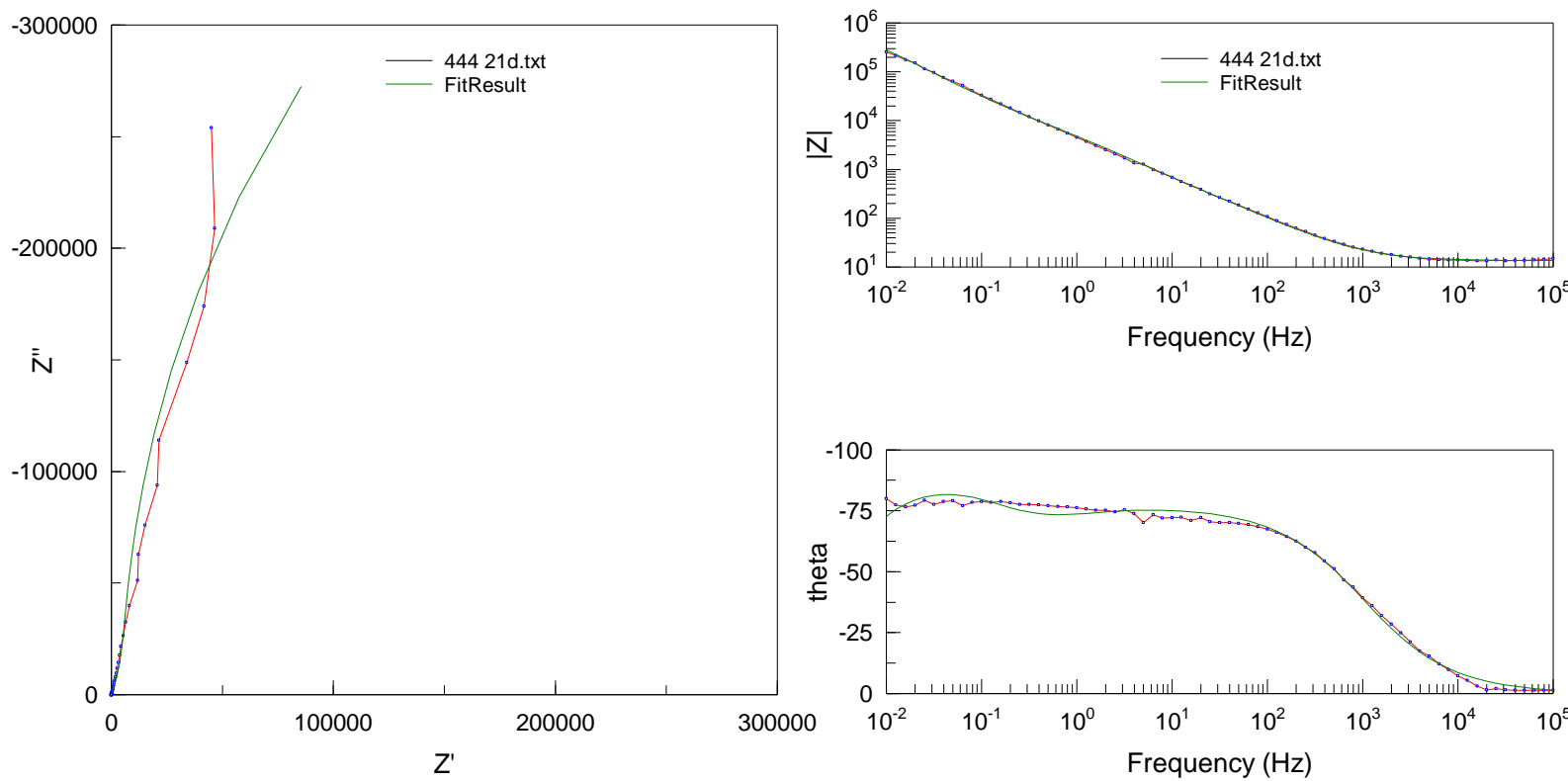

Ajustes dos diagramas de impedância pelo CEE para o aço AISI 444, após 21 dias de imersão em solução PBS a $37^{\circ} \mathrm{C}$. 


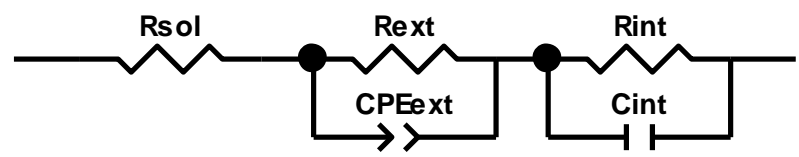

\begin{tabular}{|c|c|c|c|c|}
\hline Element & Freedom & $\underline{\text { Value }}$ & Error & Error \% \\
\hline Rsol & Free $(+)$ & 24,36 & 0,076909 & 0,31572 \\
\hline Rext & Free $(+)$ & 20241 & 2086,7 & 10,309 \\
\hline CPEext-T & Free $(+)$ & 0,00012249 & $2,1514 \mathrm{E}-06$ & 1,7564 \\
\hline CPEext-P & Free $(+)$ & 0,78223 & 0,0022919 & 0,293 \\
\hline Rint & Free $(+)$ & $2,2592 E 06$ & 1,572E05 & 6,9582 \\
\hline Cint & Free $(+)$ & $4,4153 \mathrm{E}-05$ & $4,1344 \mathrm{E}-07$ & 0,93638 \\
\hline \multicolumn{2}{|c|}{ Chi-Squared: } & \multicolumn{3}{|l|}{0,001272} \\
\hline \multicolumn{2}{|c|}{ Weighted Sum of Squares: } & \multicolumn{3}{|l|}{0,17299} \\
\hline \multicolumn{2}{|l|}{ Data File: } & \multicolumn{3}{|c|}{ C:IUsers $\backslash$ Rogerio|Documents $\backslash$ Doutorado $\backslash$ Resultados } \\
\hline \multicolumn{2}{|c|}{ Circuit Model File: } & \multicolumn{3}{|c|}{ C:IUsers $\backslash$ Rogerio $\backslash$ Documents $\backslash$ Doutorado $\backslash$ Resultados } \\
\hline \multicolumn{2}{|l|}{ Mode: } & \multicolumn{3}{|c|}{ Run Fitting / Freq. Range $(0,001-1000000)$} \\
\hline \multicolumn{2}{|c|}{ Maximum Iterations: } & \multicolumn{3}{|l|}{100} \\
\hline \multicolumn{2}{|c|}{ Optimization Iterations: } & \multicolumn{3}{|l|}{0} \\
\hline \multicolumn{2}{|c|}{ Type of Fitting: } & \multicolumn{3}{|l|}{ Complex } \\
\hline \multicolumn{2}{|c|}{ Type of Weighting: } & \multicolumn{3}{|c|}{ Calc-Modulus } \\
\hline
\end{tabular}
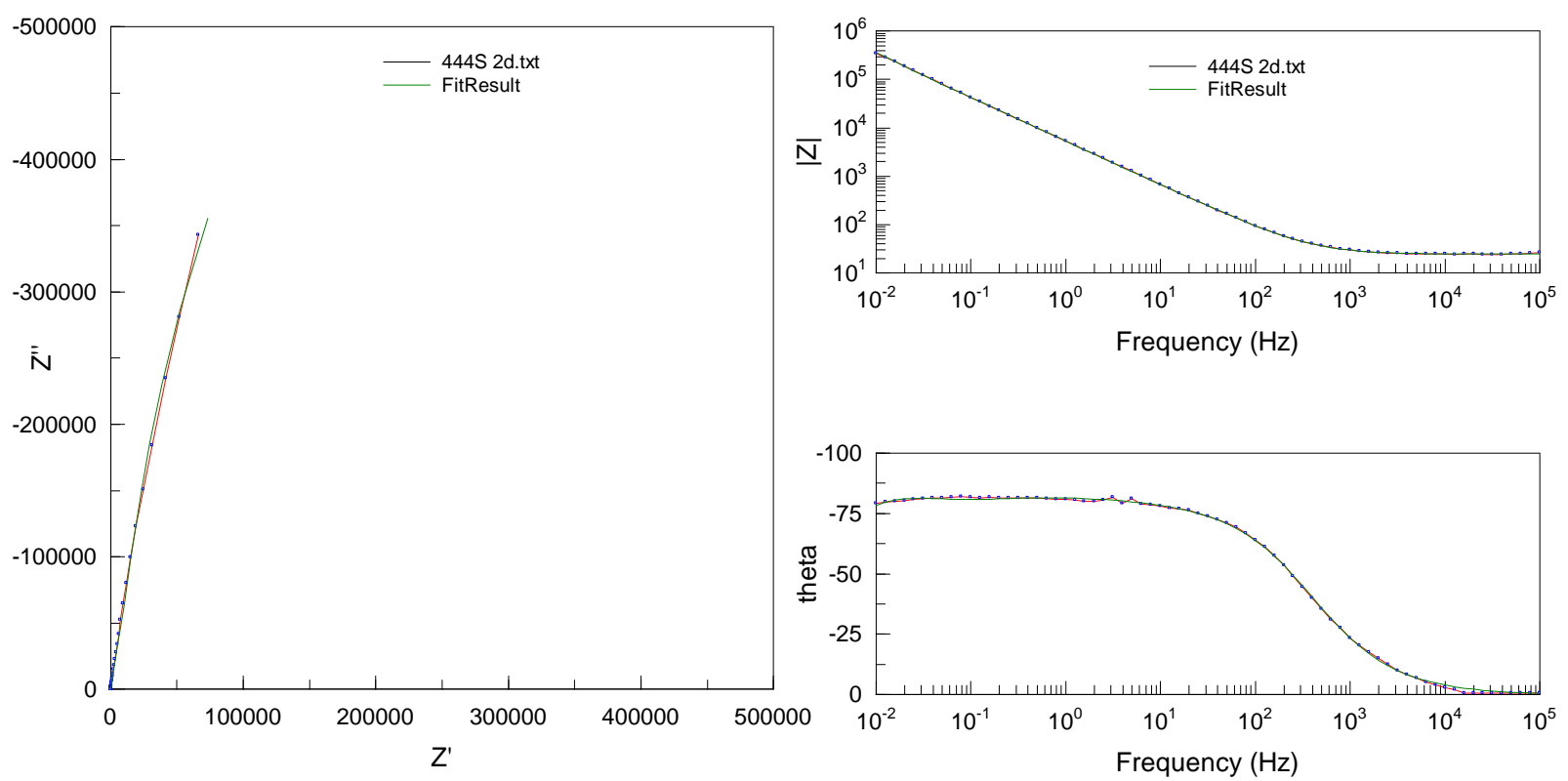

Ajustes dos diagramas de impedância pelo CEE para o aço AISI 444S, após 2 dias de imersão em solução PBS a $37^{\circ} \mathrm{C}$. 


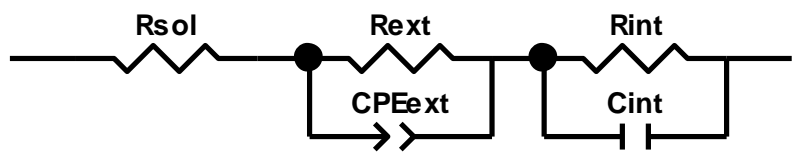

\begin{tabular}{|c|c|c|c|c|}
\hline Element & Freedom & Value & Error & Error \% \\
\hline Rsol & Free $(+)$ & 33,85 & 0,15272 & 0,45117 \\
\hline Rext & Free(+) & 25008 & 1920,8 & 7,6807 \\
\hline CPEext-T & Free $(+)$ & 6,8249E-05 & $9,9016 \mathrm{E}-07$ & 1,4508 \\
\hline CPEext-P & Free $(+)$ & 0,75712 & 0,002279 & 0,30101 \\
\hline Rint & Free $(+)$ & 2,6607E06 & 2,1888E05 & 8,2264 \\
\hline Cint & Free $(+)$ & 3,5832E-05 & $3,4569 \mathrm{E}-07$ & 0,96475 \\
\hline
\end{tabular}

Chi-Squared: $\quad 0,0018086$

Weighted Sum of Squares: $\quad 0,24596$

Data File: $\quad$ C:IUsers $\backslash$ Rogerio $\quad$ Documents $\backslash$ DoutoradolResultados

Circuit Model File: $\quad$ C:IUsers $\backslash$ RogeriolDocuments $\backslash$ DoutoradolResultados

Mode: $\quad$ Run Fitting / Freq. Range $(0,001-1000000)$

Maximum Iterations: $\quad 100$

Optimization Iterations: $\quad 0$

Type of Fitting: Complex

Type of Weighting: Calc-Modulus
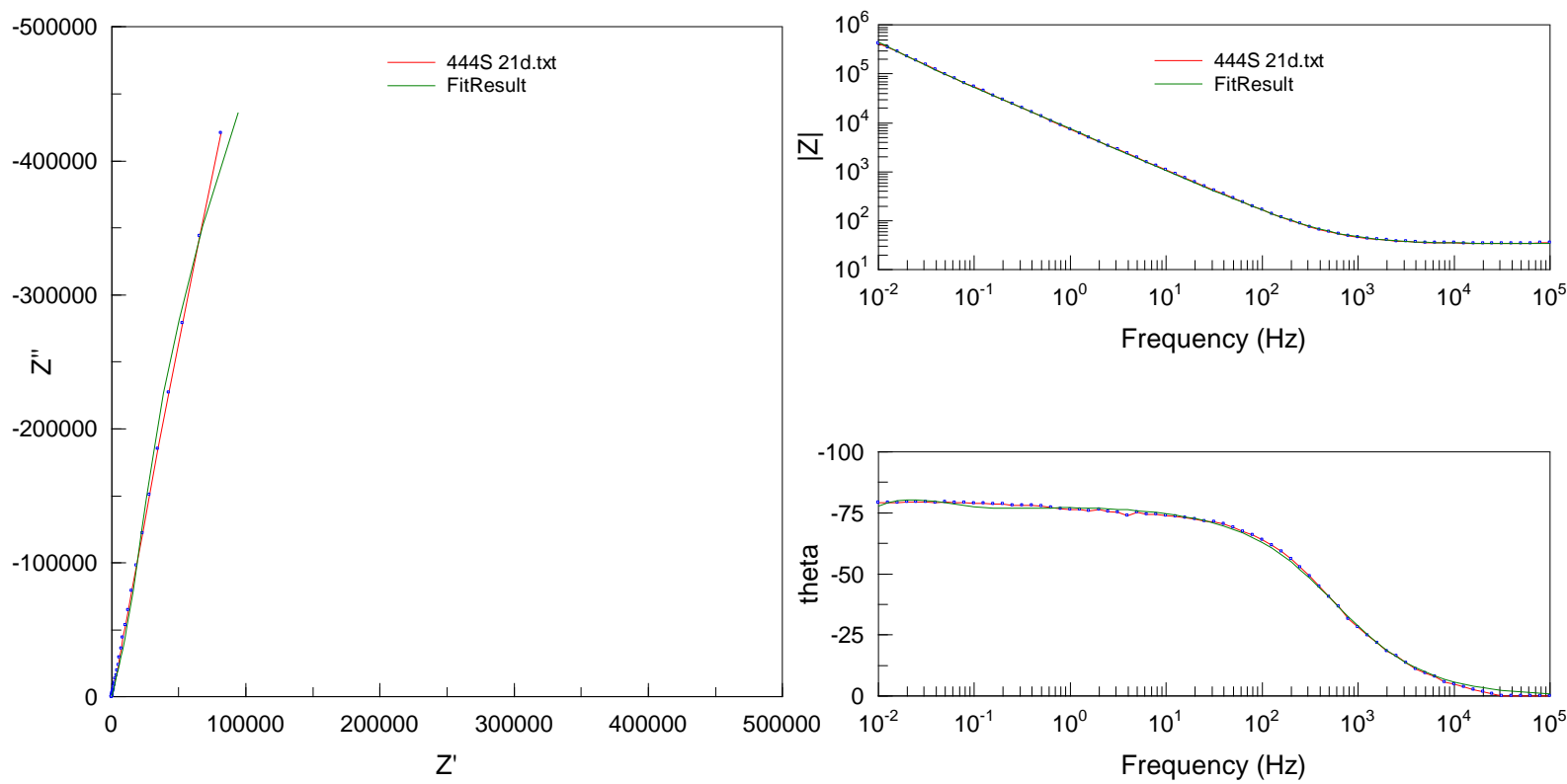

Ajustes dos diagramas de impedância pelo CEE para o aço AISI 444S, após 21 dias de imersão em solução PBS a $37^{\circ} \mathrm{C}$. 


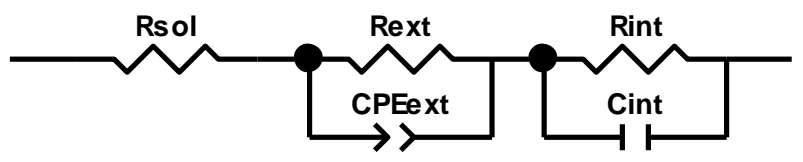

\begin{tabular}{|c|c|c|c|c|}
\hline Element & Freedom & Value & Error & Error \% \\
\hline Rsol & Free(+) & 19,26 & 0,066404 & 0,34478 \\
\hline Rext & Fixed $(X)$ & 18254 & $\mathrm{~N} / \mathrm{A}$ & $\mathrm{N} / \mathrm{A}$ \\
\hline CPEext-T & Free(+) & 0,00013967 & $2,6978 \mathrm{E}-06$ & 1,9316 \\
\hline CPEext-P & Free(+) & 0,78817 & 0,0027578 & 0,3499 \\
\hline Rint & Free(+) & 3,5739E06 & 2,7644E05 & 7,735 \\
\hline Cint & Free $(+)$ & 3,6528E-05 & 1,5874E-07 & 0,43457 \\
\hline
\end{tabular}

Chi-Squared: $\quad 0,0016109$

Weighted Sum of Squares: $\quad 0,22069$

Data File: $\quad$ C:IUsers $\backslash$ Rogerio $\backslash$ Documents $\backslash$ DoutoradolResultados

Circuit Model File: $\quad$ C:IUsers $\backslash$ RogeriolDocuments $\backslash$ DoutoradolResultados

Mode: $\quad$ Run Fitting / Freq. Range $(0,001-1000000)$

Maximum Iterations: $\quad 100$

Optimization Iterations: $\quad 0$

Type of Fitting: Complex

Type of Weighting: Calc-Modulus
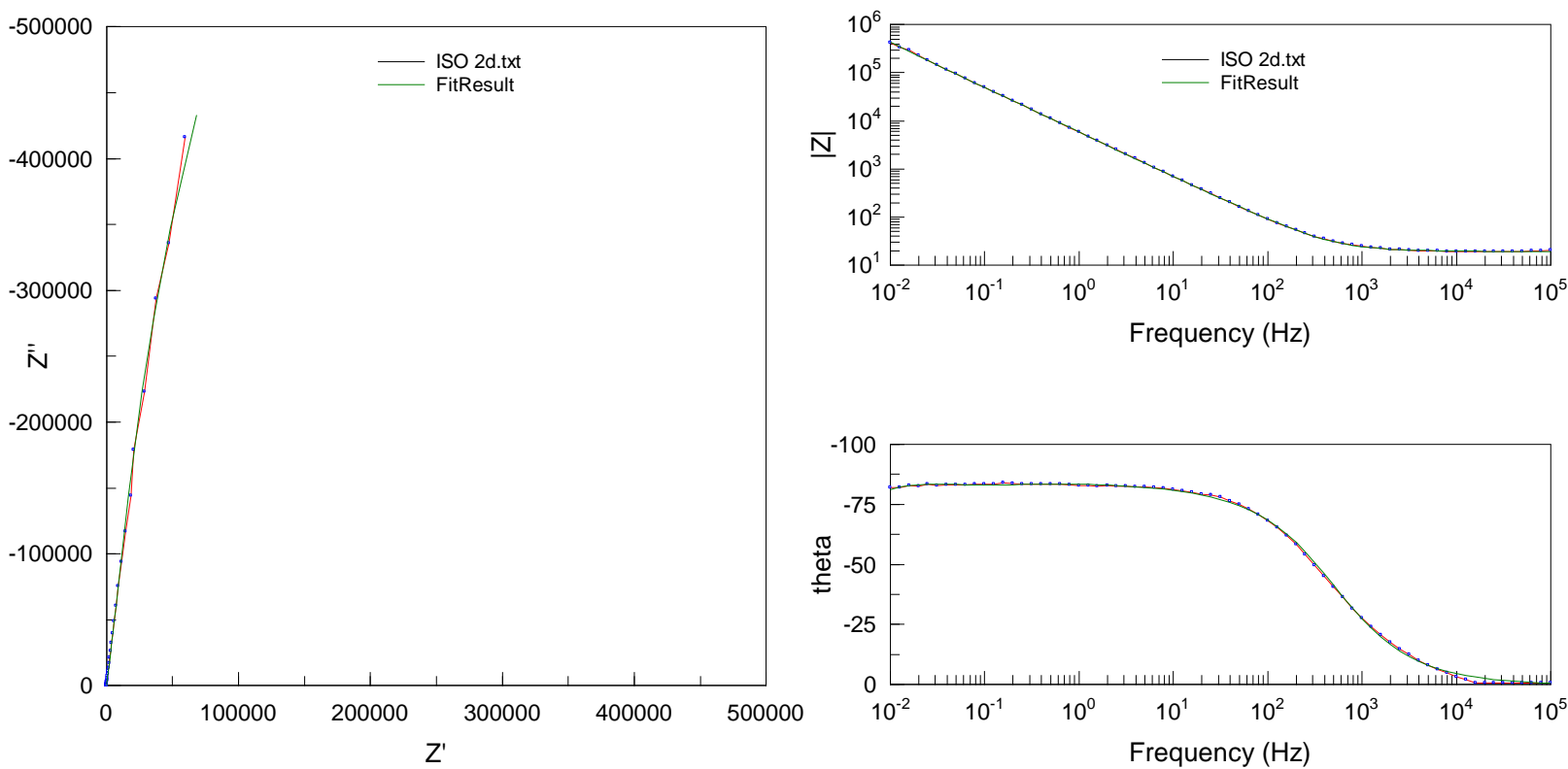

Ajustes dos diagramas de impedância pelo CEE para o aço ISO 5832-1, após 2 dias de imersão em solução PBS a $37^{\circ} \mathrm{C}$. 


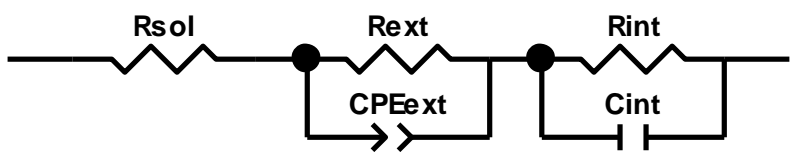

$\begin{array}{lllll}\text { Element } & \text { Freedom } & \text { Value } & \text { Error } & \text { Error } \% \\ \text { Rsol } & \text { Free }(+) & 39,98 & 0,2166 & 0,54177 \\ \text { Rext } & \text { Free }(+) & 35742 & 3118,5 & 8,725 \\ \text { CPEext-T } & \text { Free }(+) & 4,9973 \mathrm{E}-05 & 7,7538 \mathrm{E}-07 & 1,5516 \\ \text { CPEext-P } & \text { Free }(+) & 0,74736 & 0,0024192 & 0,3237 \\ \text { Rint } & \text { Free }(+) & 2,8298 \mathrm{E} 06 & 2,3794 \mathrm{E} 05 & 8,4084 \\ \text { Cint } & \text { Free }(+) & 2,9151 \mathrm{E}-05 & 3,4868 \mathrm{E}-07 & 1,1961\end{array}$

Chi-Squared: $\quad 0,0022106$

Weighted Sum of Squares: $\quad 0,30065$

Data File: $\quad$ C:IUsers $\quad$ Rogerio|Documents $\quad$ DoutoradolResultados

Circuit Model File: $\quad$ C:IUsers $\quad$ RogeriolDocuments $\backslash$ DoutoradolResultados

Mode: $\quad$ Run Fitting / Freq. Range (0,001 - 1000000)

Maximum Iterations: $\quad 100$

Optimization Iterations: $\quad 0$

Type of Fitting: Complex

Type of Weighting: Calc-Modulus
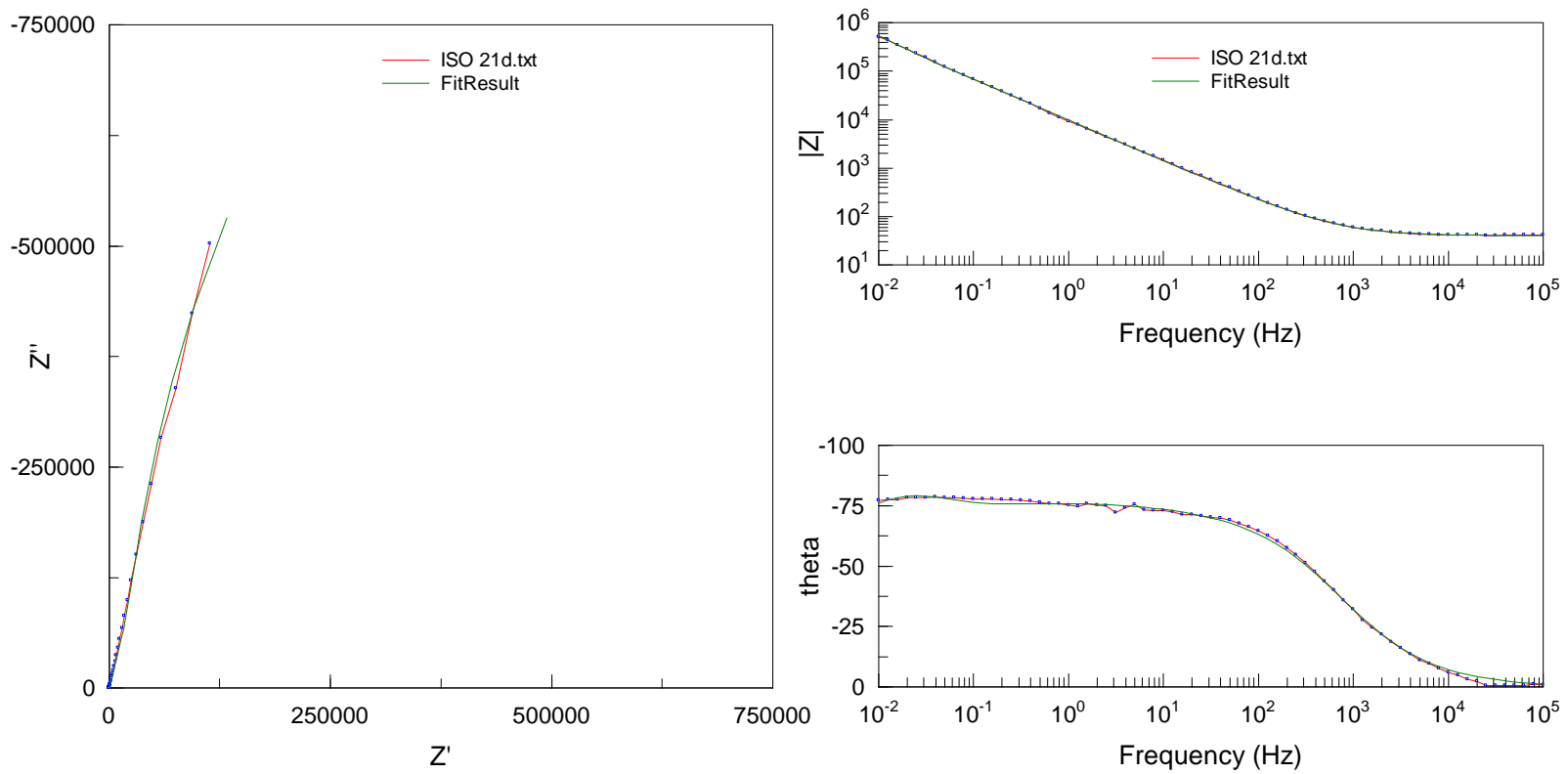

Ajustes dos diagramas de impedância pelo CEE para o aço ISO 5832-1, após 21 dias de imersão em solução PBS a $37^{\circ} \mathrm{C}$. 


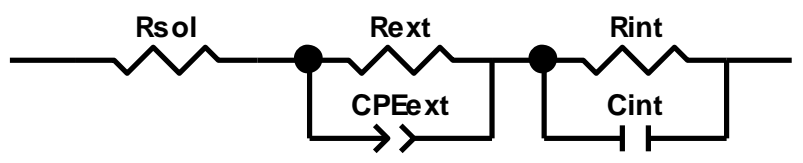

\begin{tabular}{|c|c|c|c|c|}
\hline Element & Freedom & Value & Error & Error \% \\
\hline Rsol & $\overline{\text { Free }(+)}$ & $\overline{10,31}$ & $\overline{0,12973}$ & 1,2583 \\
\hline Rext & Free $(+)$ & 4113 & 192,18 & 4,6725 \\
\hline CPEext-T & Free $(+)$ & 0,00013437 & 3,6437E-06 & 2,7117 \\
\hline CPEext-P & Free $(+)$ & 0,77995 & 0,0048876 & 0,62666 \\
\hline Rint & Free(+) & 92900 & 6739,1 & 7,2541 \\
\hline Cint & Free $(+)$ & 0,00032696 & 7,1808E-06 & 2,1962 \\
\hline
\end{tabular}

Chi-Squared: $\quad 0,0099587$

Weighted Sum of Squares: $\quad 1,3544$

Data File:

C: $\mid$ Users $\backslash$ Rogerio $\backslash$ Documents $\backslash$ Doutorado $\backslash$ Resultados

Circuit Model File:

C:IUsers $\backslash$ RogeriolDocuments $\backslash$ DoutoradolResultados

Mode:

Maximum Iterations: Run Fitting / Freq. Range (0,001 - 1000000)

Optimization Iterations: 100

Type of Fitting:

0

Type of Weighting:

Complex

Calc-Modulus
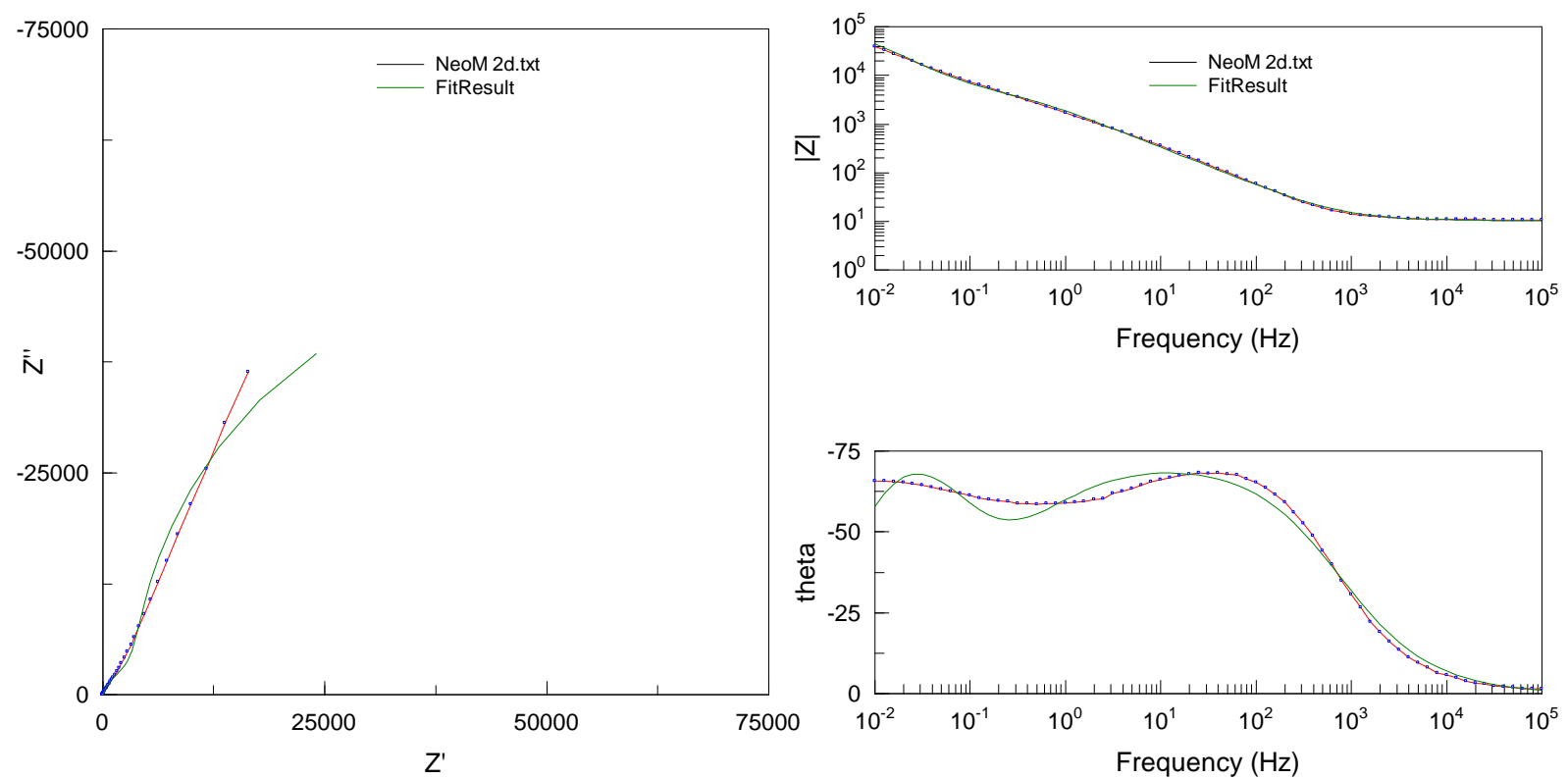

Ajustes dos diagramas de impedância pelo CEE para o aço NeoM, após 2 dias de imersão em solução PBS a $37^{\circ} \mathrm{C}$. 


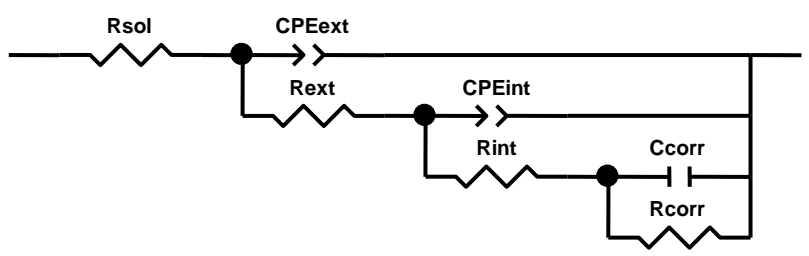

\begin{tabular}{|c|c|c|c|c|}
\hline Element & Freedom & $\underline{\text { Value }}$ & Error & Error \% \\
\hline Rsol & $\overline{\operatorname{Free}(+)}$ & $\overline{30,706}$ & $\overline{0,020477}$ & $\overline{0,55254}$ \\
\hline CPEext-T & Free(+) & 4,8349E-05 & 1,0825E-06 & 2,2389 \\
\hline CPEext-P & Free (+) & 0,84042 & 0,002669 & 0,31758 \\
\hline Rext & Free(+) & 1424 & 135,91 & 9,5442 \\
\hline CPEint-T & Free (+) & 4,0673E-05 & 1,1604E-06 & 2,853 \\
\hline CPEint-P & Free(+) & 0,69276 & 0,0071383 & 1,0304 \\
\hline Rint & Free(+) & 44669 & 1967,7 & 4,4051 \\
\hline Ccorr & Fixed $(X)$ & 0,00012009 & $\mathrm{~N} / \mathrm{A}$ & $\mathrm{N} / \mathrm{A}$ \\
\hline Rcorr & Free(+) & 2,6692E05 & 25690 & 9,6246 \\
\hline \multicolumn{2}{|c|}{ Chi-Squared: } & \multicolumn{3}{|l|}{0,00082906} \\
\hline \multicolumn{2}{|c|}{ Weighted Sum of Squares: } & \multicolumn{3}{|l|}{0,11109} \\
\hline \multicolumn{2}{|l|}{ Data File: } & \multicolumn{3}{|c|}{ 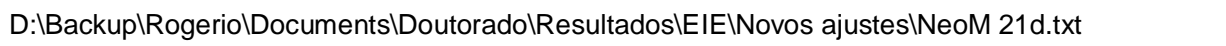 } \\
\hline \multicolumn{2}{|c|}{ Circuit Model File: } & \multirow{2}{*}{\multicolumn{3}{|c|}{ 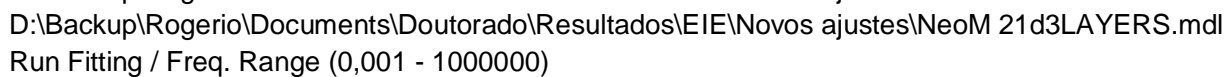 }} \\
\hline \multicolumn{2}{|l|}{ Mode: } & & & \\
\hline \multicolumn{2}{|c|}{ Maximum Iterations: } & \multicolumn{3}{|c|}{$\begin{array}{l}\text { Run Fittıng / Freq. Range }(0,001-1000000) \\
100\end{array}$} \\
\hline \multicolumn{2}{|c|}{ Optimization Iterations: } & \multicolumn{3}{|l|}{0} \\
\hline \multicolumn{2}{|c|}{ Type of Fitting: } & \multicolumn{3}{|l|}{ Complex } \\
\hline \multicolumn{2}{|c|}{ Type of Weighting: } & \multicolumn{3}{|l|}{ Calc-Modulus } \\
\hline
\end{tabular}
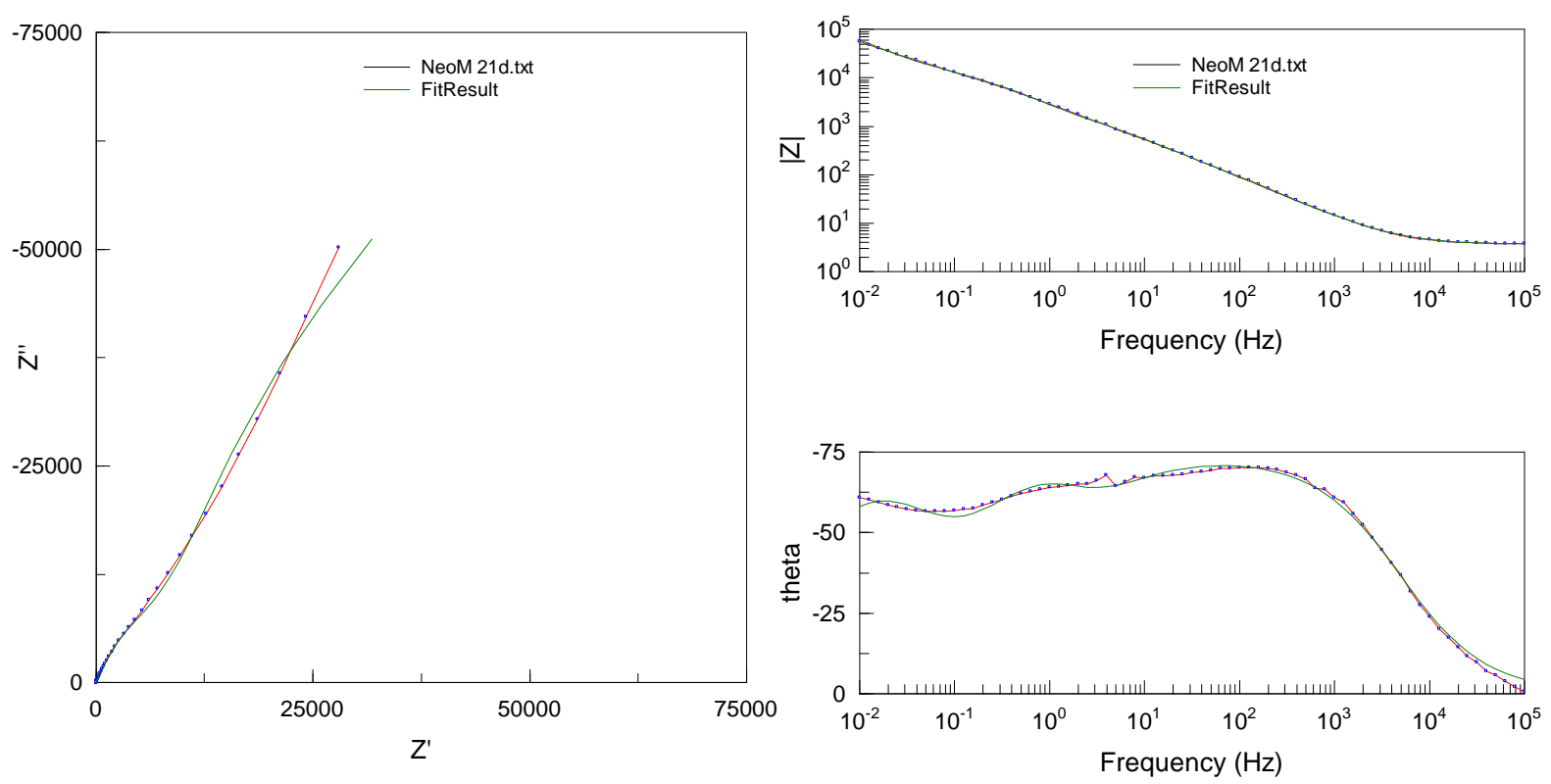

\footnotetext{
Ajustes dos diagramas de impedância pelo CEE para o aço NeoM, após 21 dias de imersão em solução PBS a $37^{\circ} \mathrm{C}$.
} 


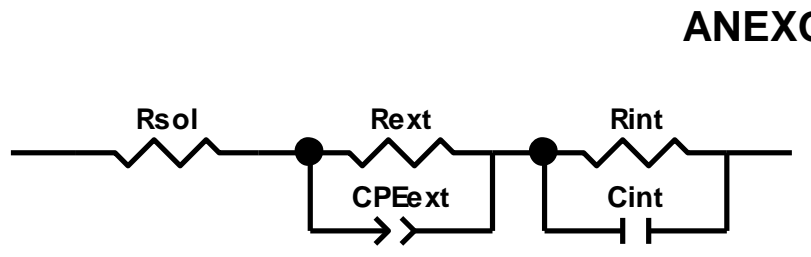

\begin{tabular}{|c|c|c|c|c|}
\hline Element & Freedom & $\underline{\text { Value }}$ & Error & Error \% \\
\hline Rsol & Free $(+)$ & 28,35 & 0,10804 & 0,38109 \\
\hline Rext & Fixed(X) & 32247 & $\mathrm{~N} / \mathrm{A}$ & $\mathrm{N} / \mathrm{A}$ \\
\hline CPEext-T & Free $(+)$ & 0,00017099 & 2,8026E-06 & 1,639 \\
\hline CPEext-P & Free $(+)$ & 0,76827 & 0,0026638 & 0,34673 \\
\hline Rint & Free $(+)$ & 1,3804E06 & 1,3569E05 & 9,8298 \\
\hline Cint & Free $(+)$ & 8,9477E-05 & 6,4194E-07 & 0,71744 \\
\hline
\end{tabular}

Chi-Squared: $\quad 0,0020475$

Weighted Sum of Squares: $\quad 0,28051$

Data File: $\quad$ C:IUsers $\backslash$ Rogerio|Documents $\backslash$ Doutorado|Resultados

Circuit Model File: $\quad$ C:IUsers $\backslash$ RogeriolDocuments $\backslash$ DoutoradolResultados

Mode: $\quad$ Run Fitting / Freq. Range $(0,001-1000000)$

Maximum Iterations: $\quad 100$

Optimization Iterations: $\quad 0$

Type of Fitting:

Complex

Type of Weighting: Calc-Modulus
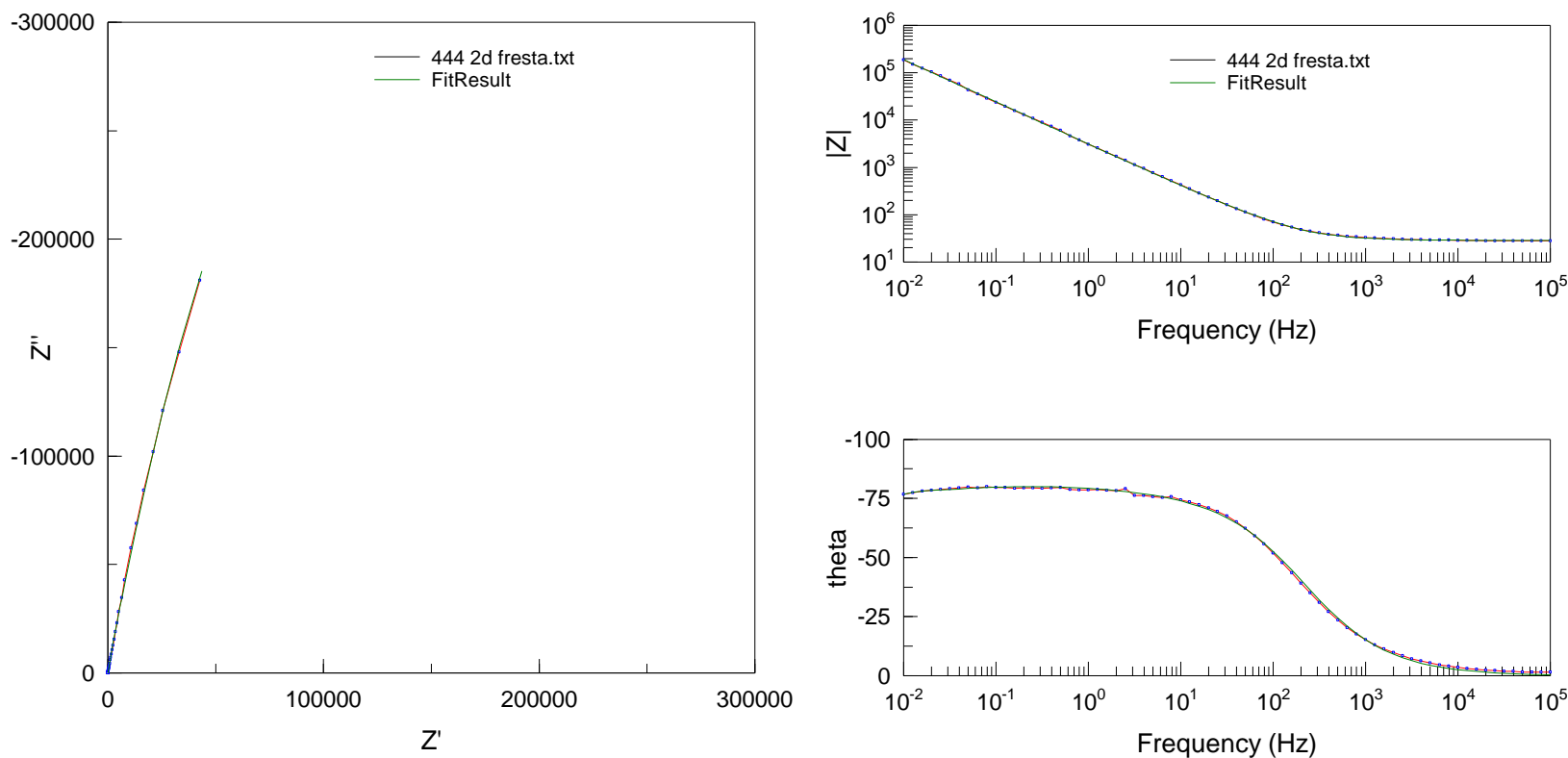

Ajustes dos diagramas de impedância pelo CEE para o aço AISI 444, após 2 dias de imersão em solução PBS a $37^{\circ} \mathrm{C}$, sob condição de fresta. 


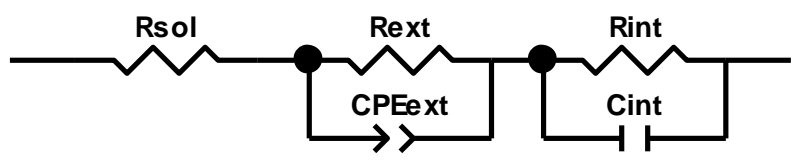

\begin{tabular}{|c|c|c|c|c|}
\hline Element & Freedom & Value & Error & Error \% \\
\hline Rsol & Free $(+)$ & 24,74 & 0,093079 & 0,37623 \\
\hline Rext & Fixed $(X)$ & 31592 & $\mathrm{~N} / \mathrm{A}$ & $\mathrm{N} / \mathrm{A}$ \\
\hline CPEext-T & Free $(+)$ & 0,00015044 & 2,0533E-06 & 1,3649 \\
\hline CPEext-P & Free $(+)$ & 0,74754 & 0,0021842 & 0,29219 \\
\hline Rint & Free(+) & 1,671E06 & 1,6089E05 & 9,6284 \\
\hline Cint & Free $(+)$ & 8,0285E-05 & 4,96E-07 & 0,6178 \\
\hline
\end{tabular}

Chi-Squared: $\quad 0,0015135$

Weighted Sum of Squares: $\quad 0,20736$

Data File: $\quad$ C:IUsers $\backslash$ Rogerio|Documents $\backslash$ Doutorado|Resultados

Circuit Model File: $\quad$ C:IUsers $\backslash$ RogeriolDocuments $\backslash$ DoutoradolResultados

Mode: $\quad$ Run Fitting / Freq. Range $(0,001-1000000)$

Maximum Iterations: $\quad 100$

Optimization Iterations: $\quad 0$

Type of Fitting:

Complex

Type of Weighting: Calc-Modulus
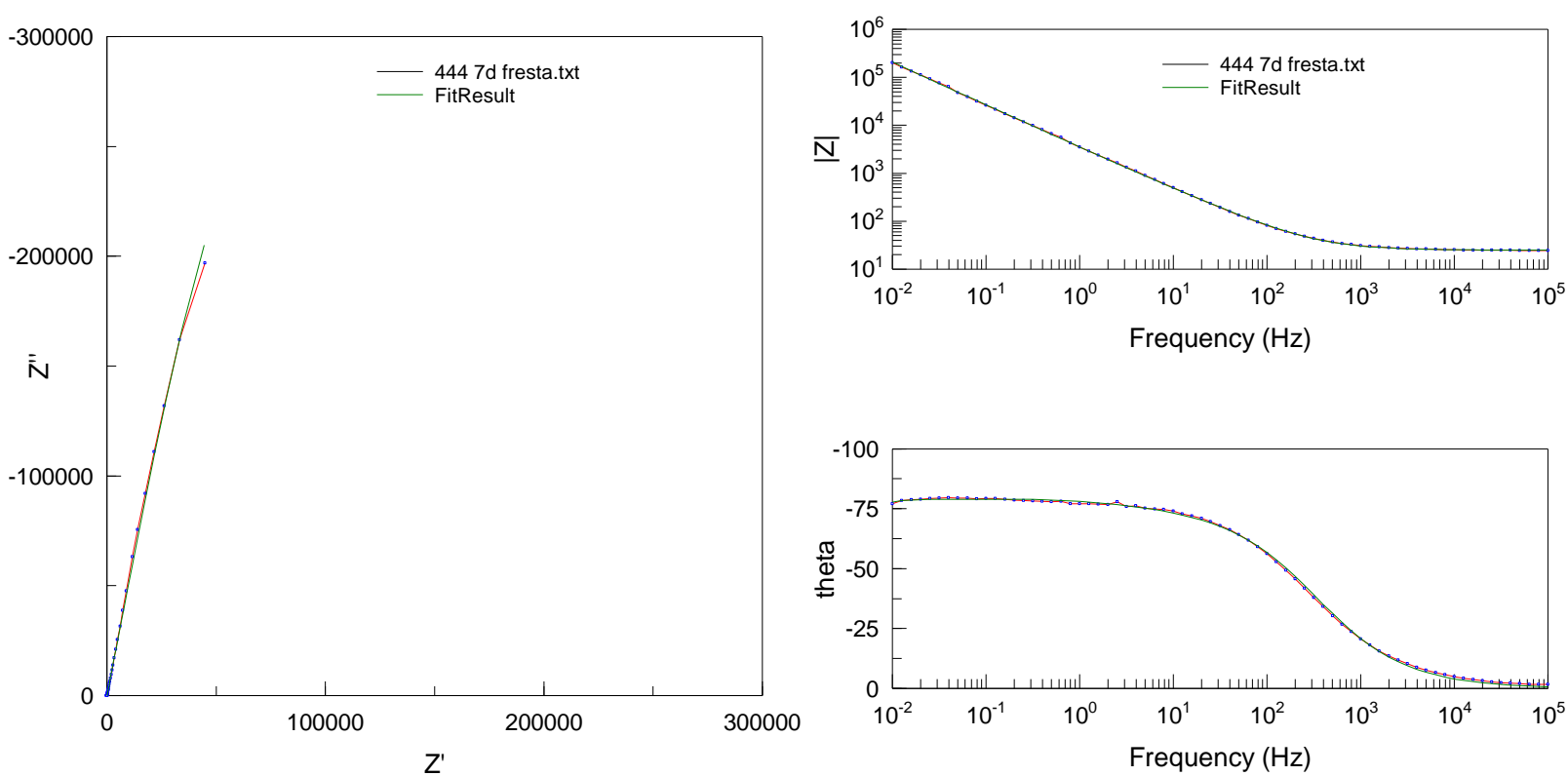

Ajustes dos diagramas de impedância pelo CEE para o aço AISI 444, após 7 dias de imersão em solução PBS a $37^{\circ} \mathrm{C}$, sob condição de fresta. 


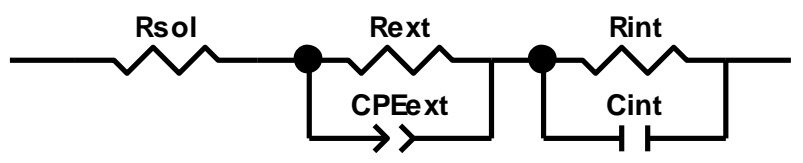

\begin{tabular}{|c|c|c|c|c|}
\hline Element & Freedom & Value & Error & Error \% \\
\hline Rsol & Free(+) & 15,09 & 0,095769 & 0,63465 \\
\hline Rext & Fixed(X) & 36937 & $\mathrm{~N} / \mathrm{A}$ & $N / A$ \\
\hline CPEext-T & Free $(+)$ & 0,00021279 & 4,9685E-06 & 2,3349 \\
\hline CPEext-P & Free $(+)$ & 0,70183 & 0,0034153 & 0,48663 \\
\hline Rint & Free(+) & 7,6261E05 & 59561 & 7,8102 \\
\hline Cint & Free $(+)$ & $9,318 \mathrm{E}-05$ & 9,6962E-07 & 1,0406 \\
\hline
\end{tabular}

Chi-Squared: $\quad 0,0028146$

Weighted Sum of Squares: $\quad 0,38561$

Data File: $\quad$ C:IUsers $\backslash$ Rogerio|Documents $\backslash$ Doutorado|Resultados

Circuit Model File: $\quad$ C:IUsers $\backslash$ RogeriolDocuments $\backslash$ DoutoradolResultados

Mode:

Maximum Iterations:

Run Fitting / Freq. Range (0,001 - 1000000)

Optimization Iterations:

100

Type of Fitting:

0

Type of Weighting:

Complex

Calc-Modulus
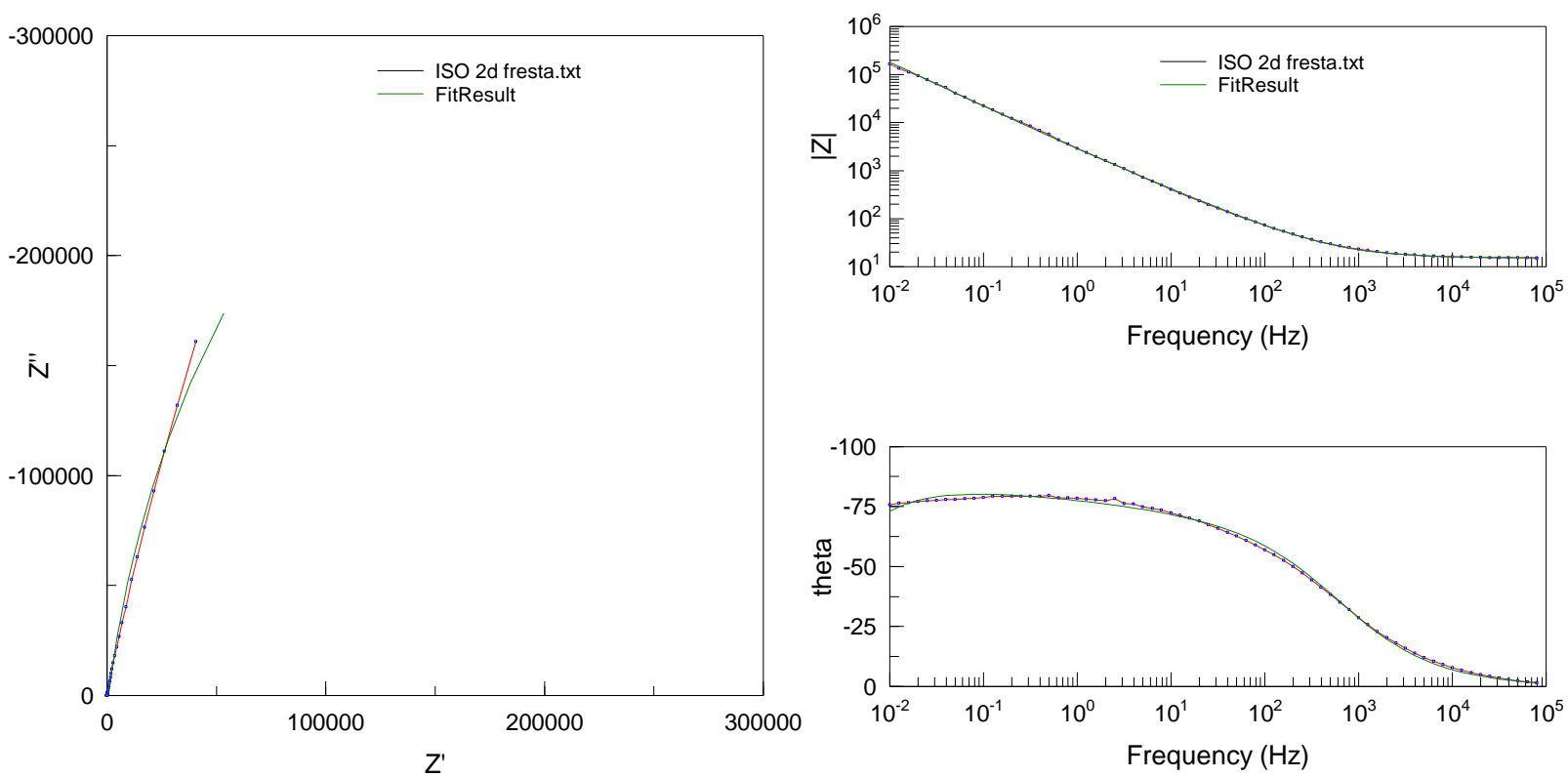

Ajustes dos diagramas de impedância pelo CEE para o aço ISO 5832-1, após 2 dias de imersão em solução PBS a $37^{\circ} \mathrm{C}$, sob condição de fresta. 


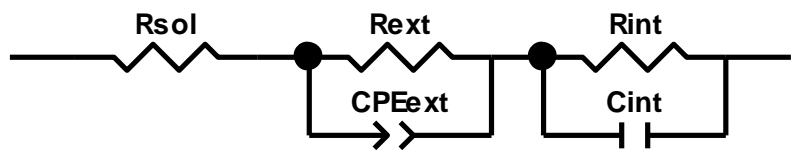

\begin{tabular}{|c|c|c|c|c|}
\hline Element & Freedom & Value & Error & Error \% \\
\hline Rsol & Free $(+)$ & 26,04 & 0,08755 & 0,336 \\
\hline Rext & Fixed $(X)$ & 32484 & $\mathrm{~N} / \mathrm{A}$ & $\mathrm{N} / \mathrm{A}$ \\
\hline CPEext-T & Free(+) & 0,00015617 & $2,0771 \mathrm{E}-06$ & 1,33 \\
\hline CPEext-P & Free $(+)$ & 0,75338 & 0,0021177 & 0,2810 \\
\hline Rint & Free(+) & 1,7097E06 & 1,5055E05 & 8,8056 \\
\hline Cint & Free(+) & 7,8576E-05 & $4,5011 \mathrm{E}-07$ & 0,572 \\
\hline
\end{tabular}

Chi-Squared: $\quad 0,0013277$

Weighted Sum of Squares: $\quad 0,1819$

Data File: $\quad$ C:IUsers $\backslash$ Rogerio|Documents $\backslash$ Doutorado|Resultados

Circuit Model File: $\quad$ C:IUsers $\backslash$ RogeriolDocuments $\backslash$ Doutorado|Resultados

Mode:

Maximum Iterations:

Run Fitting / Freq. Range (0,001 - 1000000)

Optimization Iterations:

100

Type of Fitting:

0

Type of Weighting:

Complex

Calc-Modulus
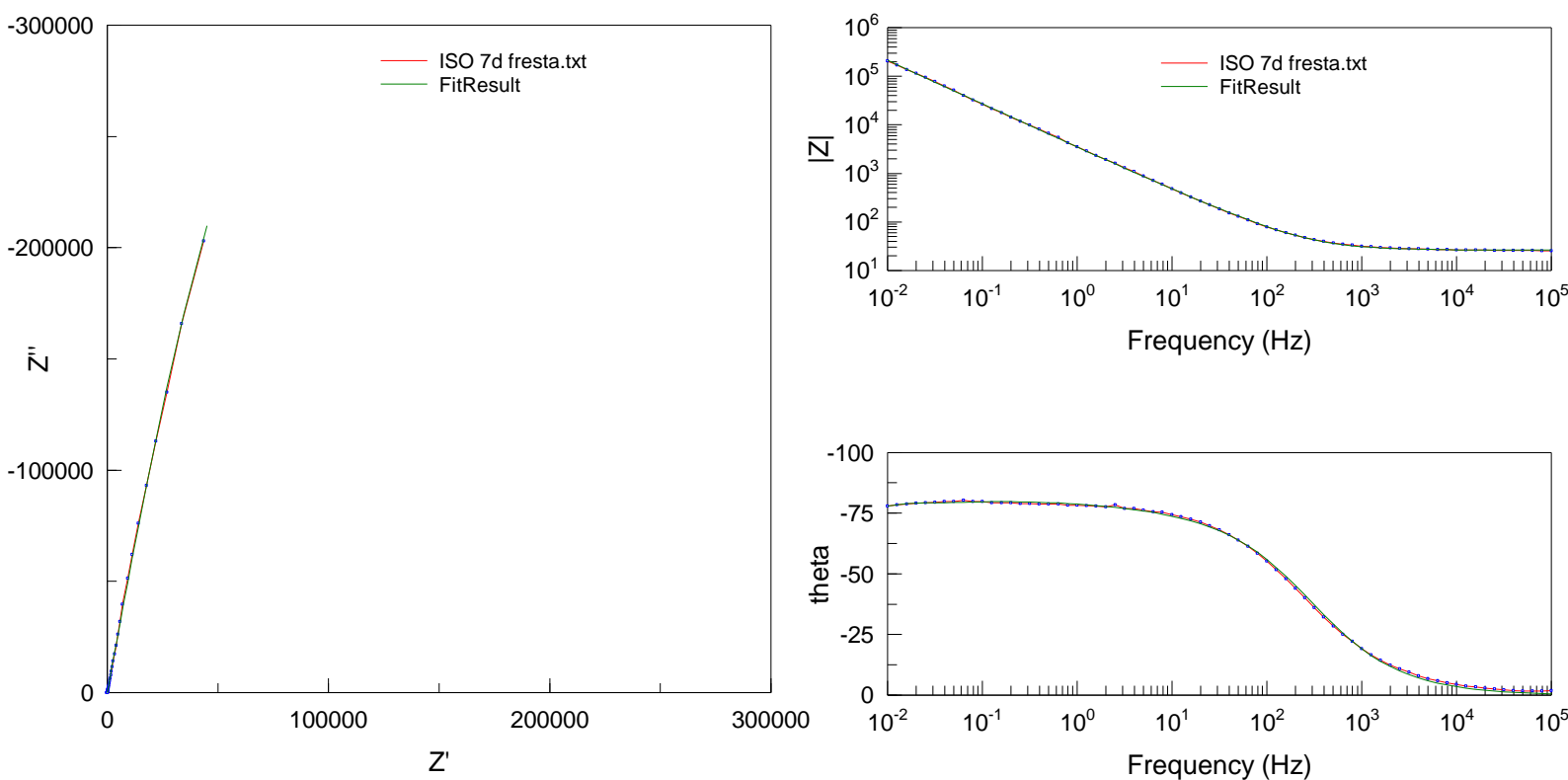

Ajustes dos diagramas de impedância pelo CEE para o aço ISO 5832-1, após 7 dias de imersão em solução PBS a $37^{\circ} \mathrm{C}$, sob condição de fresta. 